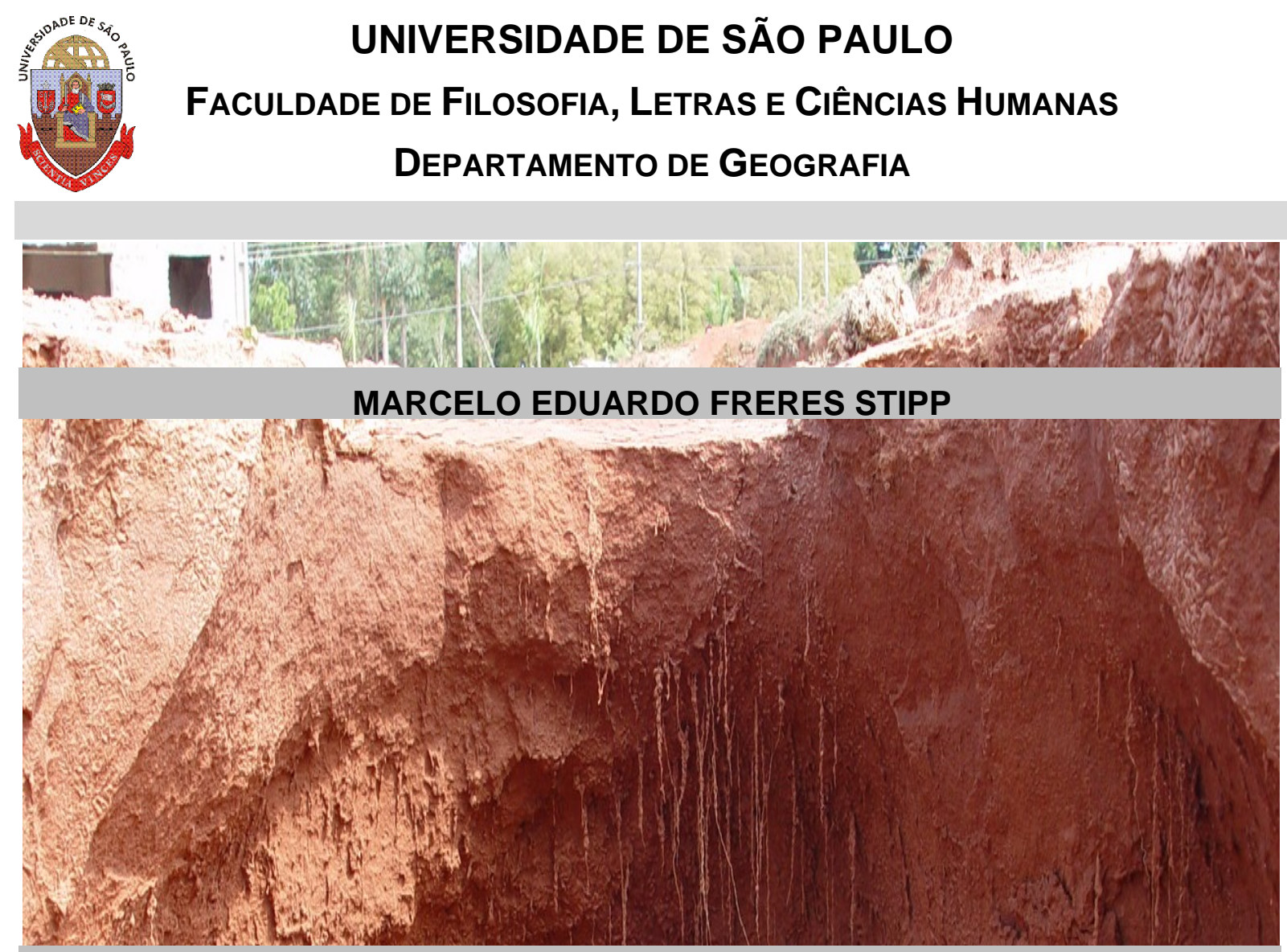

A OCUPAÇÃO DO SOLO E A PROBLEMÁTICA DA ARENIZAÇÃO E DO VOÇOROCAMENTO NO MUNICÍPIO DE PARANAVAÍ/PR

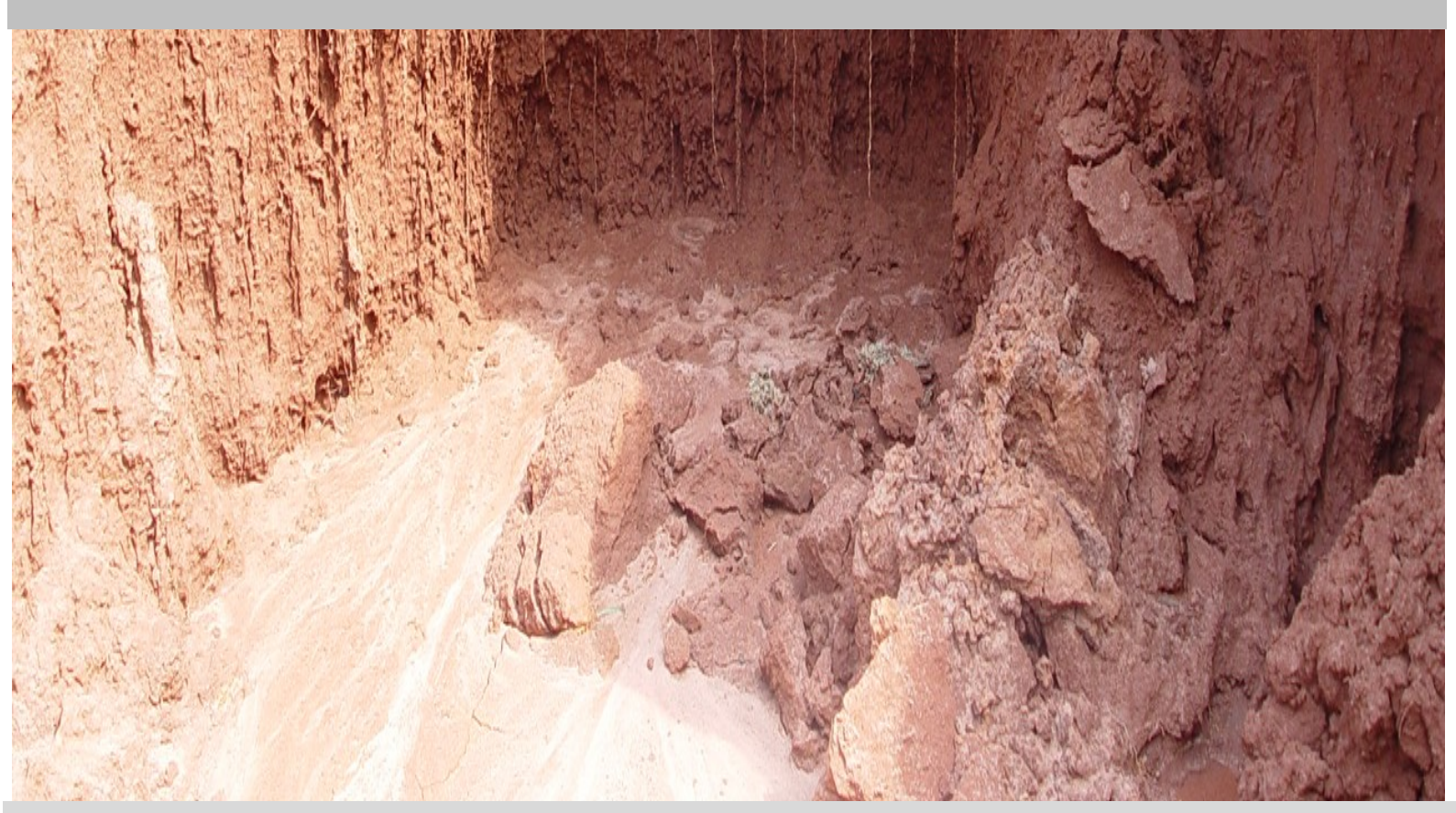


MARCELO EDUARDO FRERES STIPP

\section{A OCUPAÇÃO DO SOLO E A PROBLEMÁTICA DA ARENIZAÇÃO E DO VOÇOROCAMENTO NO MUNICÍPIO DE PARANAVAÍ/PR}

Tese apresentada à Faculdade de Filosofia, Letras e Ciências Humanas da Universidade de São Paulo, Departamento de Geografia, Curso de Pós-Graduação em Geografia Física, como requisito parcial à obtenção do título de Doutor em Geografia Física.

Orientador: Prof. Dr. José Bueno Conti 
MARCELO EDUARDO FRERES STIPP

\section{A OCUPAÇÃO DO SOLO E A PROBLEMÁTICA DA ARENIZAÇÃO E DO VOÇOROCAMENTO NO MUNICÍPIO DE PARANAVAÍ/PR}

Tese apresentada à Faculdade de Filosofia, Letras e Ciências Humanas da Universidade de São Paulo, Departamento de Geografia, Curso de Pós-Graduação em Geografia Física, como requisito parcial à obtenção do título de Doutor em Geografia Física.

Orientador: Prof. Dr. José Bueno Conti

COMISSÃO EXAMINADORA

Prof. Dr. José Bueno Conti

São Paulo, de de 2007. 
Dedico este trabalho

As três pessoas mais importantes da minha vida:

Minha mãe Nilza, que me fez ver o mundo como uma fonte inesgotável de estudo e conhecimento; Meu filho Arthur, que me ensinou que a felicidade e a satisfação podem ser alcançadas com um beijo; Minha esposa Claudia que me ajudou a pensar mais em mim mesmo. 


\section{AGRADECIMENTOS}

A consecução deste trabalho demandou muita paciência, perseverança, força, determinação, horas de estudo em escritório e campo, e somente foi possível pelo privilégio que tive de contar com a colaboração inestimável de uma plêiade de pessoas amigas, abaixo nominadas, que nunca deixaram de me estender as mãos nos momentos de dificuldade, e assim, sem medirem esforços e muitas vezes com sacrifícios pessoais se propuseram ao enfrentamento da lida, possibilitando-me vencer mais essa etapa de minha vida acadêmica, aos quais manifesto os meus mais escolhidos agradecimentos:

Ao meu orientador Prof. Dr. José Bueno Conti, que acreditou em mim desde o primeiro momento em que the apresentei a idéia sobre uma nova metodologia, e no decorrer dessa caminhada esteve sempre ao meu lado nas apresentações e seminários me auxiliando e muitas vezes me defendendo e embasando com seu conhecimento científico, contribuindo assim, para o aperfeiçoamento desta pesquisa;

Em especial a Prof ${ }^{a}$. Drª. Nilza Aparecida Freres Stipp, pelo apoio científico, as horas de discussão e redação deste trabalho;

Ao meu "pai postiço" Jeovahrley de Souza pela palavra amiga e pelo incentivo em todo o tempo, bem como pela ajuda na correção da ortografia deste trabalho;

Ao amigo Ricardo A. Campos, por muitos sábados e domingos em que permaneceu junto comigo na formatação desta tese;

Ao amigo Ênio Luiz Debarba pela ajuda na fase inicial da pesquisa;

Ao CNPq pelo auxílio e custeio, por meio de bolsa, propiciando condições para dedicação integral ao curso de Pós-graduação;

Ao programa de Pós-graduação em Geografia Física da Faculdade de Filosofia Letras e Ciências Humanas, USP / São Paulo; 
À secretaria de Pós-graduação em Geografia da Faculdade de Filosofia Letras e Ciências Humanas, em especial Ana Lucia L. Pereira e Jurema R. Navarro;

Ao amigo João Henrique Caviglione pela ajuda técnica na adequação das cartas temáticas.

Ao amigo Rigoberto L. Pietro pela colaboração na interpretação das imagens de satélite;

Ao Prof. Dr. André Celligoi pelo apoio científico na área da geologia;

À Faculdade de Filosofia de Paranavaí/ Pr na figura do amigo Auro Lima Carvalho pela colaboração durante a parte experimental desta pesquisa;

À Faculdade de Filosofia Ciências e Letras de Cornélio Procópio / $\operatorname{Pr}$, na figura do amigo Prof. Aécio Rodrigues de Melo, chefe do Departamento de Geografia pelo apoio e compreensão de que necessitei na fase de conclusão desta pesquisa. 
STIPP, Marcelo Eduardo Freres. A ocupação do solo e problemática da arenização em Paranavaí/Pr. 2006. Tese (Doutorado em Geografia Física) Faculdade de Filosofia, Letras e Ciências Humanas da Universidade de São Paulo.

\section{RESUMO}

Esta pesquisa apresenta a aplicação de uma nova metodologia de medição de carreamento de solo, que foi utilizada durante o período de um ano, na área urbana de Paranavaí, no estado do Paraná. Teve como objetivo avaliar a fragilidade do solo e analisar os processos de erosão e arenização. Durante o seu desenvolvimento foram analisados principalmente os dados climáticos que envolveram desde as temperaturas médias anuais, índices de pluviosidade até direção e velocidade dos ventos de superfície. A partir da análise dos dados obtidos foram elaboradas cartas temáticas que permitiram um melhor entendimento do fenômeno da arenização, cerne deste trabalho. Uma série de fotos obtidas no campo auxiliou na análise e avaliação desses processos, gerando uma discussão de resultados que possibilitou tecer considerações sobre a recuperação de certas áreas onde ocorrem esses fenômenos.

Palavras-Chave: erosão - ravinas - voçorocas - arenização - desertificação carreamento de solos. 
STIPP, Marcelo Eduardo Freres. The occupation of the soil and problematic of the arenization in Paranavaí/Pr. 2006. Tese (Doutorado em Geografia Física) Faculdade de Filosofia, Letras e Ciências Humanas da Universidade de São Paulo.

\begin{abstract}
This research aims to present the application of a new methodology of measurement of soil carrying over used during one-year term in the urban area of Paranavaí, in the state of Paraná-Brazil. Aiming to evaluate the soil fragility and analyzing the erosion processes and arenization, it was analyzed during its development, the climatic data from the average annual temperatures, pluviometric rates and even the direction and speed of the winds. Starting from the analysis point of the data collected, thematic letters were elaborated allowing a better comprehension of the arenization phenomenon, core of this work. A series of pictures were taken in field that helped us in the analysis and evaluation of these processes, arousing a discussion of the results, which let us talk about the recovery of certain areas where these phenomena occur.
\end{abstract}

Keys-Words: erosion - ravines - erosion - gully - arenization - desertification- soils carry over. 
"A Geografia está entre os primeiros interesses do homem culto porque é a mais abrangente e singular das ciências. Associa fatos heterogêneos e diacrônicos e é a única comprometida ao mesmo tempo com a sociedade e com a natureza. Seus limites são os da inteligência humana e, seus horizontes, infinitos." José Bueno Conti (1997) 


\section{LISTA DE FIGURAS}

Figura 1. Ilustração de ERosÃo AcELERAdA. Des. STIPP, M. E. F., 2006........................... 22

FIGURA 2. ILUSTRAÇÃo dE EROSÃo EM LENÇOL. DES. STIPP, M. E. F., 2006.......................... 23

FiguRA 3. ILUSTRAÇÃo dE EROSÃo EM RAVINAS. DES. STIPP, M. E. F., 2006. ....................... 24

FIGURA 4. ILUSTRAÇÃO DE EROSÃO FLUVIAL. DES. STIPP, M. E. F., 2006.............................. 25

FiguRA 5. ILUSTRAÇÃo de EROSÃo POR SALPICO. DES. STIPP, M. E. F., 2006...................... 26

FiguRA 6. ILUSTRAÇÃo dE EROSÃo REMONTANTE. DES. STIPP, M. E. F., 2006 ......................27

Figura 7. ILUSTRAÇÃo dE EROSÃo EM VoçOROCAS. DES. STIPP, M. E. F., 2006.................. 30

FIGURA 8. QUADRO DE INTENSIDADE DA DESERTIFICAÇÃO.FONTE: DREGNE, 1977 APUD CONTI, 2003.

FIGURA 9. QUADRO DE CLASSIFICAÇÃO DA DESERTIFICAÇÃO NATURAL E ANTRÓPICA. FONTE: CONTI (2003).

Figura 10. ILUSTRAÇÃo de ARENIZAÇÃO. DES. STIPP, M. E. F., 2006. 38

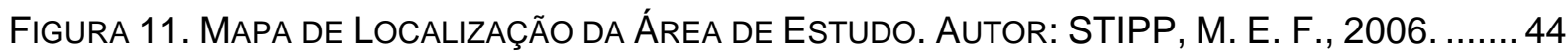

FIGURA 12. VARA DE MEDIÇÃO. AUTOR: STIPP, M. E. F., 2006 ........................................... 54

Figura 13. GRÁFICO dE RESUMO PLUVIOMÉTRICO NA EstaÇÃo ChUVOSA de PaRANAVAí. FONTE: INSTITUTO AGRONÔMICO DO PARANÁ (IAPAR), 2006.

Figura 14. GRÁFICO de RESUMO PluviomÉtRICO NA EstaÇÃo SECA dE PARANAVAí. Fonte: INSTITUTO AGRONÔMICO DO PARANÁ (IAPAR), 2006.

Figura 15. GRÁFICO de TOtaIS PluVIOMÉTRICOS dE 1974-2005 de PARANAVAí. Fonte: INSTITUTO AGRONÔMICO DO PARANÁ (IAPAR), 2006. 64

FIGURA 16. GRÁFICO DO BALANÇO HÍDRICO DE PARANAVAí. FonTE: IAPAR 2006 .................... 68

FIGURA 17. MAPA DA VEGETAÇÃO DO NOROESTE DO PARANÁ............................................. 72

FIGURA 18. CARTA DA VEGETAÇÃO REMANESCENTE DA ÁREA URBANA DE PARANAVAÍ............... 75

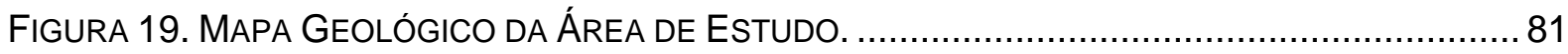

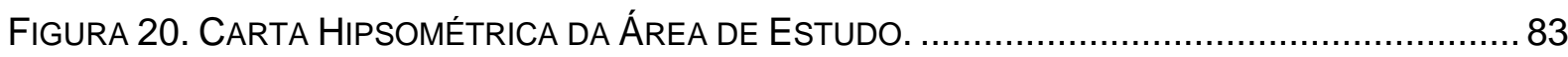

FIGURA 21. MAPA LITOLÓGICO DO PARANÁ. FONTE: SANTOS ET AL., 1991 .............................. 86

FIGURA 22. MAPA DE SOLOS DO NOROESTE DO PARANÁ. ....................................................... 94

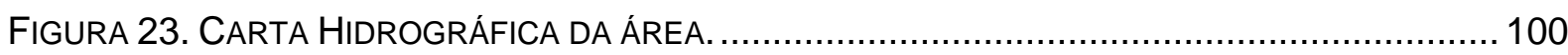

FIGURA 24. MAPA DE LOCALIZAÇÃO dOS PONTOS DE MEDIÇÃO E PLUVIÔMETROS. ................... 108

FIGURA 25. FOTO DO 1ำ PONTO DE AMOSTRAGEM. AUTOR: STIPP, M. E. F., 2003.................. 109

FIGURA 26. FOTO DO 2ํㅗ. PONTO DE AMOSTRAGEM. AUTOR: STIPP, M. E. F., 2003.................111

FIGURA 27. FOTO DO 3 PONTO DE AMOSTRAGEM. AUTOR: STIPP, M. E. F., 2003.................113

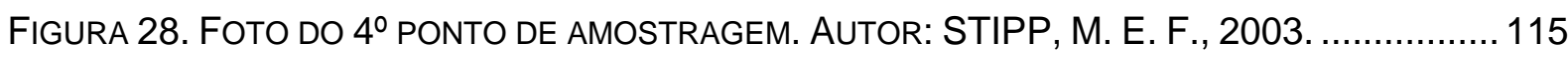

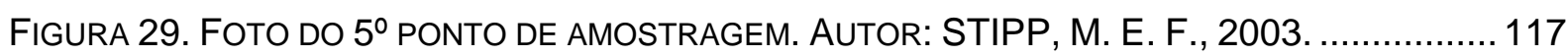

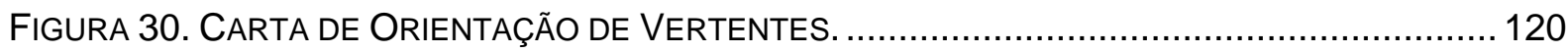




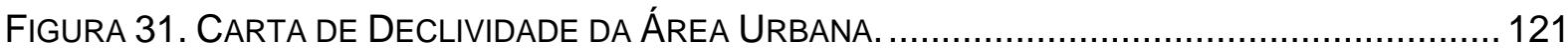

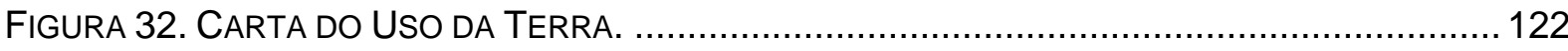

FIGURA 33. EXEMPLO DO FENÔMENO DA ARENIZAÇÃO TíPICO NA REGIÃO. AUTOR: STIPP, M. E. F., 2006 . 123

FIGURA 34. A TEXTURA MAIS ARENOSA DAS CAMADAS SUPERFICIAIS DOS SOLOS, FAVORECE A FORMAÇÃO DE SULCOS, QUE SE NÃO FOREM DEVIDAMENTE CONTROLADOS PODEM DESENVOLVER PROCESSOS EROSIVOS MAIS AGRESSIVOS COMO OS RAVINAMENTOS QUE PODE SER O EMBRIÃO DE UMA VOÇOROCA. AUTOR: STIPP, M. E. F., 2006.

FIGURA 35. ASPECTO GERAL DE UMA VOÇOROCA QUE JÁ ATINGIU O NÍVEL DE BASE. AUTOR: STIPP, M. E. F., 2006.

FIGURA 36. NOS TOPOS ARREDONDADOS AS VERTENTES SÃO MAIS CONVEXAS E QUANDO ESTÃO DESPROTEGIDAS PELA FALTA DE VEGETAÇÃO, CRIAM CONDIÇÕES DE INSTABILIDADE (MOVIMENTOS DE MASSA DOS SOLOS) COMO A FIGURA ACIMA. AUTOR: STIPP, M. E. F., 2006.

FIGURA 37. ASPECTO DE UMA VOÇOROCA LOCALIZADA AO LADO DE UMA RUA NA ENTRADA DA CIDADE DE PARANAVAÍ. AUTOR: STIPP, M. E. F., 2006.

FIGURA 38. OUTRO ASPECTO DE UMA VOÇOROCA EM ESTÁGIO BASTANTE AVANÇADO COM DUTOS NO SEU INTERIOR, OCASIONADO DEVIDO À FRAGILIDADE DOS SOLOS. AUTOR: STIPP, M. E. F., 2006 . 126

FIGURA 39. ASPECTO DA PORÇÃO INFERIOR DE UMA VERTENTE ONDE OCORRE O AFLORAMENTO DO LENÇOL FREÁTICO; E ASPECTOS DE DEGRADAÇÃO ORIGINADOS PELO PISOTEIO DO GADO. AUTOR: STIPP, M. E. F., 2006.

FIGURA 40. ASPECTO DA PARTE INFERIOR DE UMA VERTENTE ONDE SE PERCEBE OS MOVIMENTOS DE MASSA E O CARREAMENTO DE SEDIMENTOS. AUTOR: STIPP, M. E. F., 2006. 128

FIGURA 41. ASPECTO DA DEGRADAÇÃO PROMOVIDA PELA AÇÃO ANTRÓPICA QUE SE APROVEITA DA VOÇOROCA PARA DEPÓSITOS DE LIXOS DOMÉSTICOS. AUTOR: STIPP, M. E. F., 2006...... 128

FiguRA 42. DESNUDAÇÃO dO SOLO A PARTIR DE ESCORREGAMENTO DE MASSA. AUTOR: STIPP, M. E. F., 2006. 129

FIGURA 43. ASPECTO DA PORÇÃO INFERIOR DE VERTENTE ONDE AFLORA O LENÇOL FREÁTICO QUE SERVE DE BEBEDOURO PARA ANIMAIS CRIADOS SOLTOS EM PLENA ÁREA URBANA. AUTOR: STIPP, M. E. F., 2006.

FIGURA 44. MANEJO INADEQUADO DE SOLO ORIGINOU A VOÇOROCA QUE APARECE ACOMPANHANDO O SENTIDO DA DECLIVIDADE DA VERTENTE. AUTOR: STIPP, M. E. F., 2006.

FIGURA 45. UM PROCESSO DE ENVOÇOROCAMENTO EM PLENA ATIVIDADE COM VÁRIAS RAMIFICAÇÕES, ORIGINADAS PELO MANEJO INADEQUADO DO SOLO. AUTOR: STIPP, M. E. F., 2006. 130

FIGURA 46. ASPECTO GERAL DE PAISAGEM DEGRADADA NO SÍTIO URBANO DE PARANAVAÍ. AUTOR: STIPP, M. E. F., 2006.

FIGURA 47. ASPECTO DA EROSÃO DE TERRENOS COLOCANDO EM RISCO AS HABITAÇÕES LOCAIS EM UM BAIRRO RESIDENCIAL DE PARANAVAí. AUTOR: STIPP, M. E. F., 2006.

FIGURA 48. EROSÃO LAMINAR NUMA VERTENTE EM CUJO DECLIVE PODE-SE OBSERVAR UMA TRILHA DE GADO. AUTOR: STIPP, M. E. F., 2006.

Figura 49. Gráfico de Resultados Obtidos Ponto 01. Autor: STIPP, M. E. F., 2006... 134

Figura 50. Gráfico de Resultados Obtidos Ponto 02. Autor: STIPP, M. E. F., 2006... 135 
Figura 51. Gráfico de Resultados Obtidos Ponto 03. Autor: STIPP, M. E. F., 2006... 136

Figura 52. Gráfico de Resultados Obtidos Ponto 04. Autor: STIPP, M. E. F., 2006... 137

Figura 53. Gráfico de REsultados ObTidos Ponto 05. Autor: STIPP, M. E. F., 2006... 138

Figura 54. GráFICO de PrecipitAÇÃo PaRANAVAí/2003. Fonte: IAPAR, 2006. 140

FIGURA 55. GRÁFICO de PRECIPITAÇÃo PARANAVAí/2004. Fonte: IAPAR, 2006. 141

FiguRA 56. GRÁFICO DA TEMPERATURA DA ÁREA URBANA DE PARANAVAí - 2003 E 2004. FONTE: IAPAR, 2006. 142

FIGURA 57. GRÁFICO DA UMIDADE RELATIVA PARANAVAí - 2003/2004. FONTE: IAPAR, 2006. 142

FIGURA 58. GRÁFICO DE PLUVIOSIDADE TOTAL (SOMATÓRIA 2 EM 2 MESES) X DADOS COLETADOS NAS VARAS DE MEDIÇÃO. FONTE: IAPAR, 2006. 143

FIGURA 59. GRÁFICO DE VENTOS PARANAVAÍ - 2003. FONTE: IAPAR 2006. 145

FIGURA 60. GrÁFICO DE VENTOS PARANAVAí - 2003. FonTE: IAPAR 2006. 146

Figura 61. Carta de DireÇÃo e Velocidade dos Ventos de Superfície. ParanaVaí - 2006. 148

FIgURA 62. CARTA DE DIREÇÃo E VELOCIDADE dOS VENTOS DE SUPERFÍCIE COM A LOCALIZAÇÃO DAS ÁREAS DE RISCOS APONTADAS NESTE ESTUDO. PARANAVAÍ - 2006. 149

FIGURA 63. QUADRO DE CLASSES DE DECLIVIDADES. FONTE: ROSS, 1990 .......................... 150

FIGURA 64. MAPA CLINOGRÁFICO COM A LOCALIZAÇÃO dOS PONTOS DE MEDIÇÃO. ................. 151

FIGURA 65. QUADRO DE CLASSES DE FRAGILIDADE DOS SOLOS. FONTE: ROSS, 1990............ 152

FIGURA 66. QUADRO dE GRAUS DE PROTEÇÃO POR TIPOS dE COBERTURA VEGETAL. FONTE: Ross, 1990. 152

FIGURA 67. MAPA DE FRAGILIDADES AMBIENTAIS. 155

FIGURA 68. GRÁFICO dA ESTAÇÃo ChuVOSA PARANAVAí/PR. OUtUBRO/2003 À MARÇO/2004. FONTE: IAPAR, 2006. 157

Figura 69. Gráfico da EstaÇÃo Seca Paranavaí/Pr. Abril/2004 À Novembro/2004. FONTE: IAPAR, 2006. 


\section{LISTA DE TABELAS}

Tabela 1. Resumos Anuais da Temperatura Mínima na Cidade de Paranavaí - PR..........60

TABELA 2. Resumos ANuAIS dA TEMPERATURA MÁxIMA NA CIDAdE DE PARANAVAÍ - PR.........61

TABELA 3. RESUMOS ANUAIS DA PRECIPITAÇÃO DE PARANAVAÍ. ............................................ 65

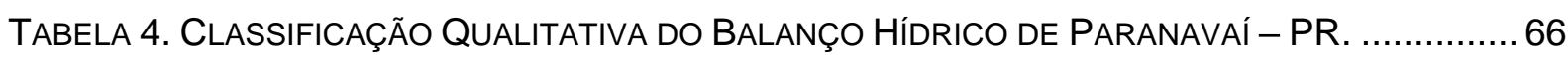

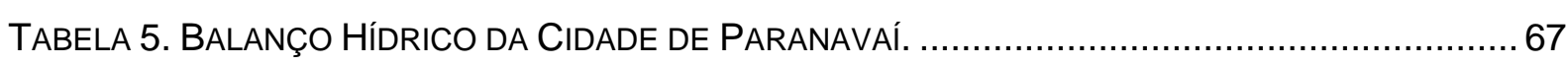

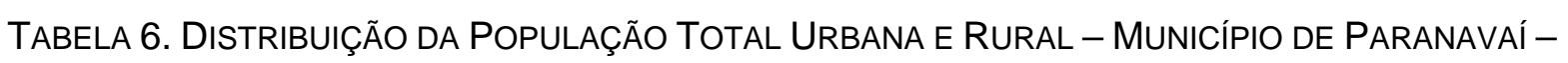

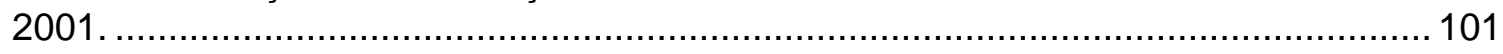

TABELA 7. População Total URbana E RuRAL Paranavaí - ParanÁ 1970 - 2000 ............. 102

TABELA 8. VALORES DA PARTICIPAÇÃO ECONÔMICA NO MUNICÍPIO DE PARANAVAí/PARANÁ

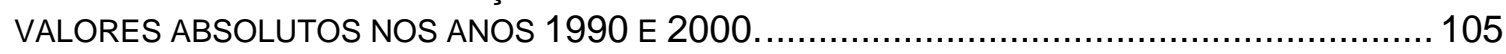

TABELA 9. GRAUS DE LIMITAÇÃO dOS PONTOS AMOSTRAdOS COM RELAÇÃO À SUSCEPTIBILIDADE

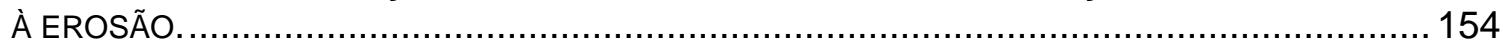




\section{SUMÁRIO}

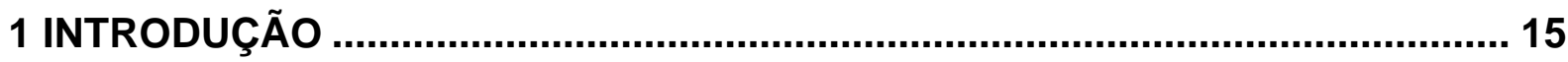

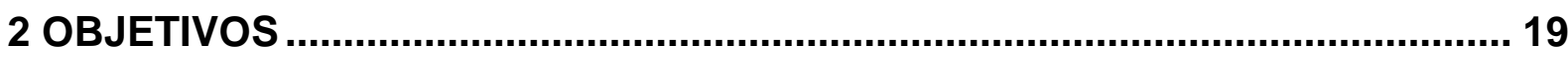

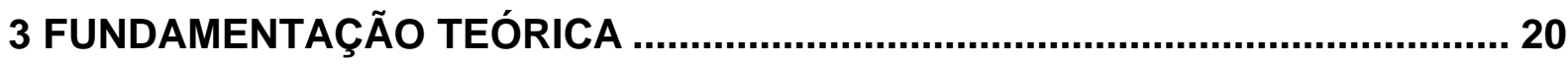

3.1 Revisão dos Processos Erosivos - AÇão dAS ÁGUAS.................................. 21

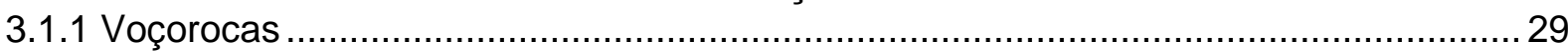

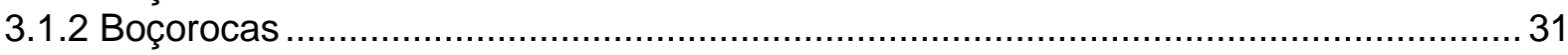

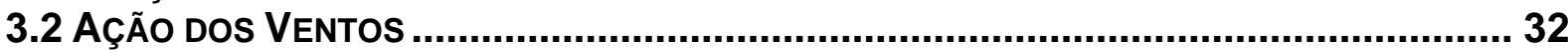

3.3 OUtras Modalidades de DegradaÇão AmBiental: DesertificaÇão E

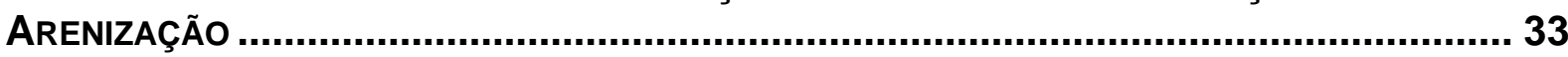

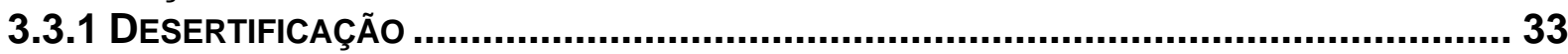

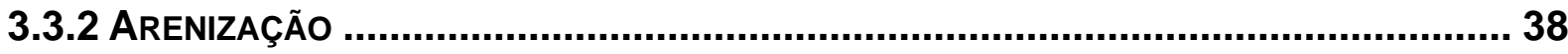

3.3.2.1 A Problemática da Arenização............................................................................. 39

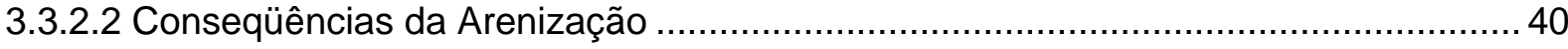

4 LOCALIZAÇÃO DA ÁREA DE ESTUDO …….................................................. 44

5 HISTÓRICO DO MUNICÍPIO DE PARANAVAÍ .................................................... 45

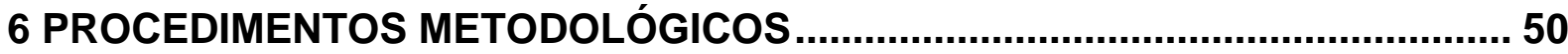

7 CARACTERIZAÇÃO FÍSICA DA ÁREA EM ESTUDO........................................56

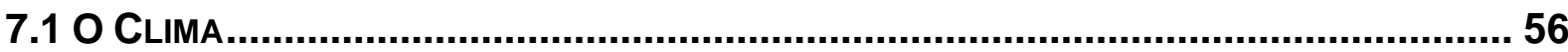

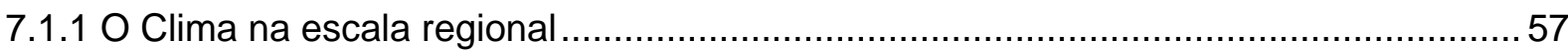

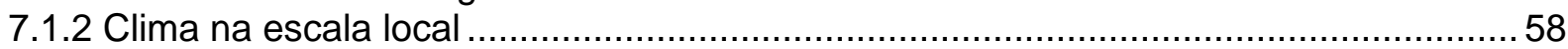

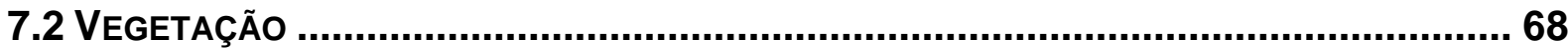

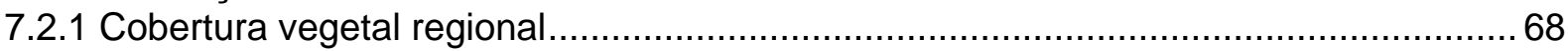

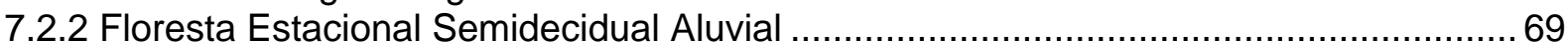

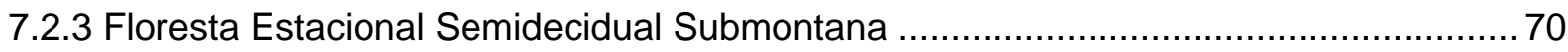

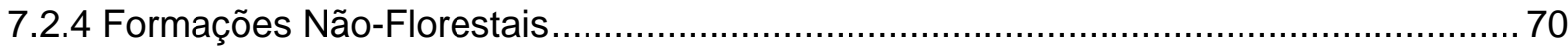

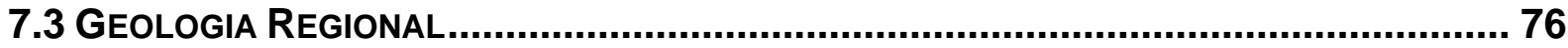

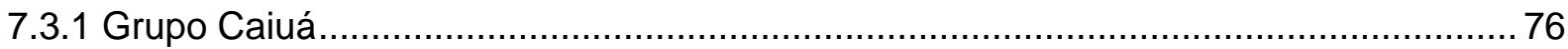

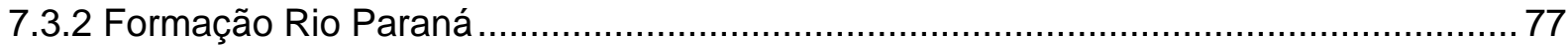

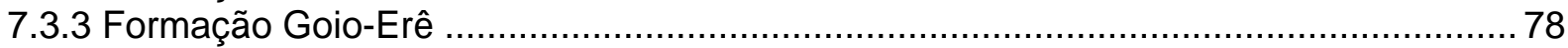

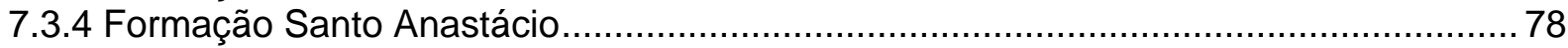

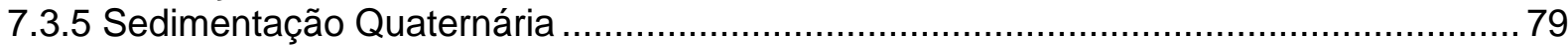

7.4 CARACTERÍSTICAS GEOMORFológICAS REGIONAIS ............................................. 82

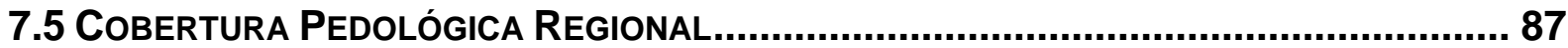

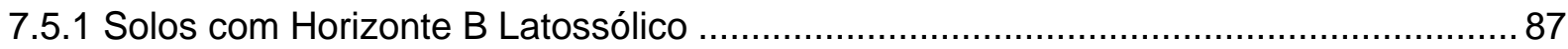

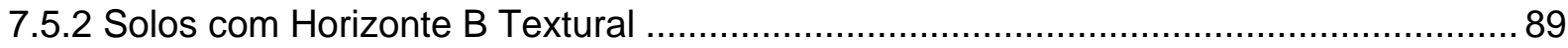

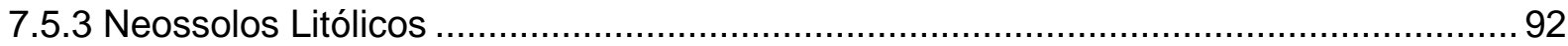

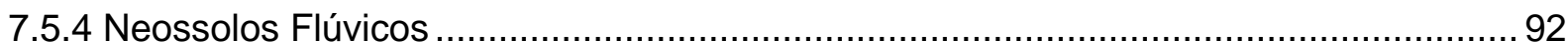

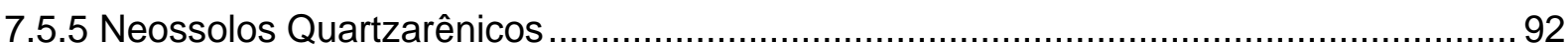

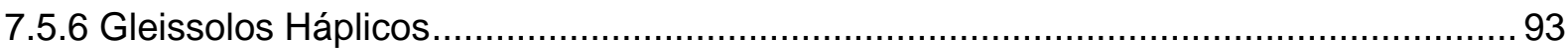

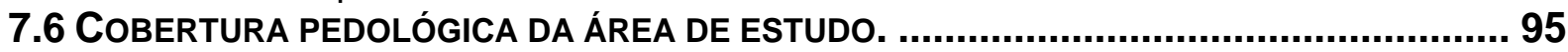

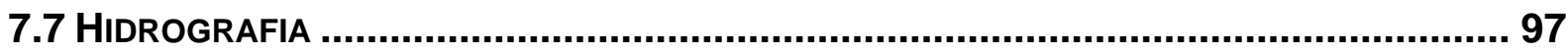


8 CARACTERIZAÇÃO HUMANA E ECONÔMICA ............................................ 101

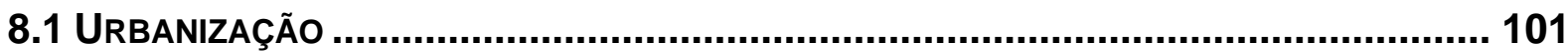

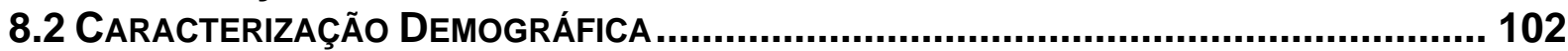

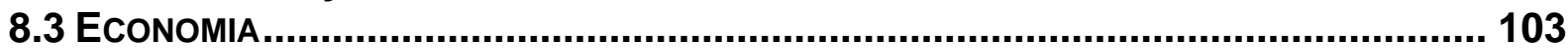

9 DESENVOLVIMENTO DA PESQUISA APLICADA .......................................... 107

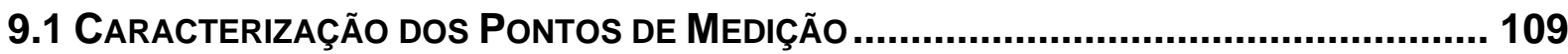

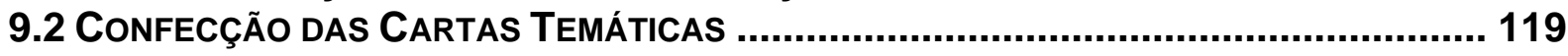

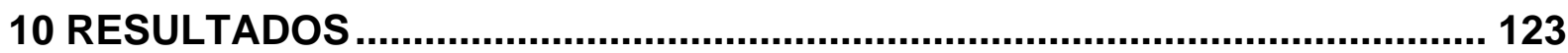

10.1 Principais Processos Erosivos Identificados em Paranavaí...................... 123

10.2 Resultados OBtidos das ANálises dos Pontos de MEdiçÃo ........................ 134

10.3 Resultados da Análise da Evolução dos Elementos Climáticos DuRante o

PERÍODO DO EXPERIMENTO .............................................................................. 139

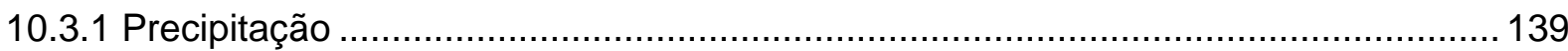

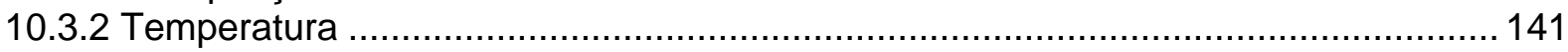

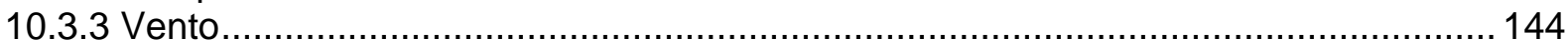

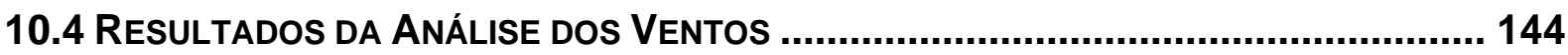

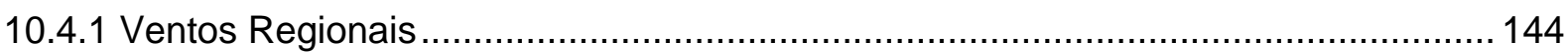

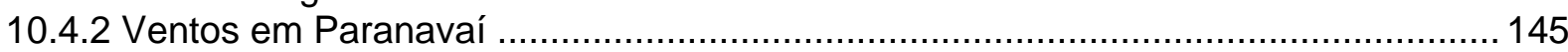

10.5 Resultados da ANÁlise dos Pontos de Medição......................................... 153

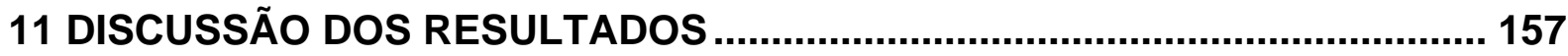

12 PROPOSTAS PARA RECUPERAÇÃO DAS ÁREAS COM PROCESSOS DE

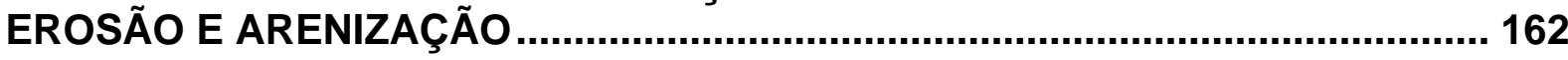

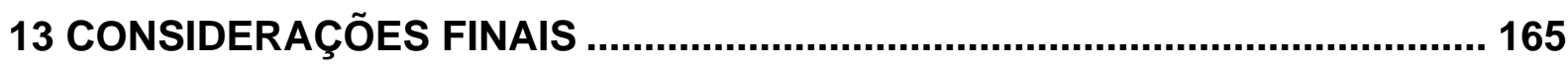

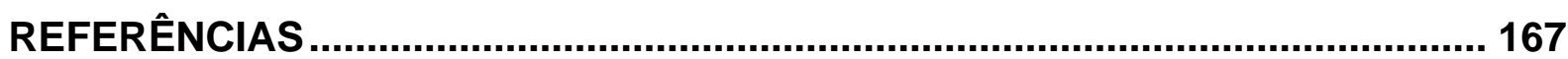

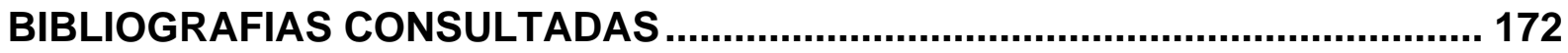




\section{INTRODUÇÃO}

Este trabalho foi estruturado visando a evidenciar áreas críticas de erosão e do processo de arenização na zona urbana de Paranavaí, fornecendo subsídios para implantação de uma política de uso racional das terras. Conseqüentemente oferecer alternativa para o controle desses processos, objetivando uma melhor ocupação do espaço urbano.

Procurou resgatar ainda a discussão da erodibilidade do solo nas áreas urbanas devido à ação antrópica como também fatores climáticos pretéritos, campo que vem sendo explorado principalmente por geomorfólogos e climatologistas.

Segundo Guerra (2003), denomina-se piso, a terra onde se fixam populações e nela se desenvolvem as mais variadas atividades, derivando daí muitas vezes o seu caráter econômico.

O sentido de propriedade da terra remonta a Revolução Francesa (1791), que a trata como direito natural.

A Declaração dos Direitos do Homem de 1789, que servirá de preâmbulo da Constituição Francesa resultante da Revolução (1791), trata a propriedade como um dos direitos naturais e imprescritíveis do homem, além de direito inviolável e sagrado (MARICATO, 1997).

Independente do valor monetário aplicado a terra, esse piso oferece às populações benefícios ou riscos dos mais variados.

Seu equilíbrio depende da evolução natural, da ação antrópica e dos componentes ambientais.

A zona urbana sempre foi o maior campo de estudo de muitos pesquisadores, pois o seu uso tornou-se o principal responsável pelas catástrofes e impactos ambientais, foco principal para o estudo da área para futuras ocupações.

Os trabalhos sobre arenização, erosão e voçorocamento realizados por diversos estudiosos têm contribuído para a equacionalização desses problemas ambientais. 
O estudo da arenização foi aprofundado por Dirce Suertegaray (1987), que a define como "deficiência da cobertura vegetal devido à intensa mobilidade dos sedimentos por ação das águas e ventos"

É um processo que envolve erosão, transporte e acumulação, o qual não pode ser confundido com desertificação.

O termo desertificação surge pela primeira vez em 1949, em um estudo francês sobre o crescimento das áreas de savanas na África tropical e subtropical.

Em 1977, em Nairobi (Quênia) uma Conferência da Organização das Nações Unidas (ONU) sobre esse tema definiu o fenômeno como a "diminuição ou destruição do potencial biológico da terra, podendo levá-la a condições do tipo desértico".

Na década de 90, alguns estudiosos restringem a definição a áreas de clima árido, semi-árido e sub-úmido.

Outros trabalhos enfocam a erosão e voçorocamento, como uma desestabilização ambiental que provoca lesões na paisagem, como uma "doença" do meio ambiente.

Os estudos sobre os deslizamentos de terra não são significativos apenas para as cidades situadas no planalto cristalino e nas zonas litorâneas próximas da Serra do Mar, como os casos de Petrópolis, Teresópolis, Caraguatatuba e Rio de Janeiro, como também para todas as áreas urbanizadas que englobam diversos tipos de escarpamentos. $O$ desenvolvimento dos estudos e mapeamentos geotécnicos vem oferecendo informações e documentos valiosos para a compreensão da dinâmica geomorfológica em áreas urbanizadas (CASSETI, 1991).

Para a aplicabilidade do conhecimento geomorfológico ao planejamento urbano se faz necessário primeiramente um estudo morfogenético para analisar os componentes do sistema físico ambiental em áreas urbanizadas e, em segundo lugar, um estudo que vise levantar dados sobre o clima, vegetação, hidrografia e pedologia da área a ser pesquisada. 
Segundo Ross (1995) o levantamento desses dois parâmetros se integraria em nível hierárquico mais complexo, à análise do ecossistema e do geossistema urbano.

Esse levantamento é essencial, pois analisa integralmente a área indispensável para o diagnóstico ambiental.

O terceiro passo consiste em analisar a vulnerabilidade das áreas urbanizadas, em face dos azares naturais (terremotos, maremotos, ciclones e tufões, enchentes, secas, deslizamentos, etc.).

\begin{abstract}
Os azares relacionados com os fenômenos geomorfológicos ganham compreensão sobre sua magnitude e frequência quando integrados aos imputs energéticos fornecidos por outras categorias de fenômenos. Por exemplo, os deslizamentos observados em 1967 na área de Caraguatatuba (Cruz, 1974), na Serra das Araras (Domingues, et all, 1971) e no Rio de Janeiro (Meis e Silva, 1968) estão interligados às precipitações ocorrentes na ocasião. A quantidade crescente de deslizamentos observados na Serra do Mar, na Baixada Santista, está possivelmente ligada às mudanças na cobertura vegetal e feitos da poluição atmosférica (TROPPMAIR \& FERREIRA, 1987).
\end{abstract}

Não se pode somente analisar os azares naturais das áreas urbanizadas, há que se estudar também os impactos provocados no meio ambiente ocasionados pela urbanização, que provocam transformações nos ecossistemas e geossistemas, diretamente, com a construção de áreas urbanizadas e indiretamente pela sua ação de influência e relações (ROSS, 1995).

Há que se considerar também os descartes produzidos pela industrialização, pelas áreas residenciais que ocasionam mudança de fluxos e os aspectos do cenário ambiental, integrando sociedade e meio ambiente.

A impermeabilização das pistas de asfalto urbanas reflete na capacidade de infiltração das águas no solo, favorecendo o escoamento superficial, concentrando as enxurradas, que segundo Ross (1995) são chamadas de ondas de cheias.

O ciclo hidrológico também é afetado pela urbanização, tornando-se necessário modificar suas trajetórias, pois provocam alterações no índice de pluviosidade dos centros urbanos, ocasionando efeitos adversos e imprevistos. 
Outros impactos diretos, em virtude da urbanização e das características geomorfológicas, referem-se às mudanças nas condições do sítio urbano, através de aterros, terraplanagens, retificações de canais, etc. 


\section{OBJETIVOS}

O presente trabalho versa sobre os processos de voçorocamento e arenização na área urbana de Paranavaí/ Pr.

Procurou-se avaliar o papel da precipitação, do vento e da ocupação do solo no referido processo analisando, portanto, dados de chuvas, balanço hídrico, temperatura, ventos e urbanização.

A pesquisa baseou-se em teorias de fragilidade ambiental do Prof. Dr. Jurandyr Luciano Sanches Ross, relativas ao meio ambiente tropical onde se encontra a área de investigação.

A hipótese, ou seja, a idéia central do trabalho é a de que os agentes climáticos, embora atuem de maneira conjunta, produzem diferentes resultados no desencadeamento dos processos de voçorocamento e arenização, em função das características locais de declividade e exposição das forças erosivas, bem como da intensidade da ação antrópica. 


\section{FUNDAMENTAÇÃO TEÓRICA}

Procurou-se estudar neste trabalho os impactos ambientais urbanos, que vem sendo alvo de inúmeros estudos geográficos e para tanto, se fez necessário a elaboração de um diagnóstico ambiental da área.

O conceito de diagnóstico ambiental envolve tudo aquilo que se pode levantar de dados eco-físicos sobre o objeto de estudo, visando conhecer sua dinâmica, funcionalidade e formação.

Somente após a aquisição desses dados é que se pode pensar num planejamento ambiental para a área ou até mesmo num plano de recuperação de áreas degradadas.

Por isso esta pesquisa se baseou no conceito de planejamento de Guerra (2003), um processo que repercute nas características, funcionamento e dinâmica das organizações espaciais.

Segundo Ottens (1990) o planejamento inclui tomadas de decisões a longo ou médio prazo, conjunto de pesquisas, discussão sobre o tema, assessorias e negociações.

Todo planejamento deve levar em conta os sistemas ambientais físicos (geossistemas), como também os sistemas sócio-econômicos da área a ser estudada.

O planejamento serve para determinar a espacialidade da ação, bem como o funcionamento e dinâmica das organizações espaciais.

Vários pesquisadores que se dedicaram ao estudo do planejamento urbano podem ser mencionados, tais como: Cooke (1982); Toy e Hadley (1987); Hook (1988); Ross (1990); Casseti (1991) e Gregory (1992).

Como primeiro passo para o planejamento deve-se optar pelo levantamento das principais características, materiais componentes e processos atuantes no espaço urbano. Esse levantamento é necessário através da pesquisa, 
pois auxilia na compreensão do modelado terrestre como sistema ambiental físico e condicionante para as atividades humanas e organização espacial.

Assim optou-se pela pesquisa aplicada desenvolvida por Guerra (2003), que envolve a coleta e análise dos dados geomorfológicos, levantamento bibliográfico, pesquisa de campo, observação da compartimentação topográfica, das formas das vertentes, rochas, clima e vegetação, formas do relevo, gênese, tamanho, dinâmica, fragilidade, problemas de erosão e assoreamento.

A escolha foi motivada pelo cerco científico que essa forma disponibiliza e a ampla coleta de dados para análise, pois para o estudo do meio urbano se faz necessário também levantar conceitos ecossistêmicos da área.

\subsection{ReVISÃo dos Processos Erosivos - AÇÃo dAs ÁGUAS}

O processo de esculturação do relevo se dá através dos seguintes agentes externos: chuvas, rios, ventos, gelo e mar. Erosão, para o geógrafo e geólogo, implica na realização de um conjunto de ações que modelam a paisagem. O pedólogo e o agrônomo consideram a erosão apenas do ponto de vista da destruição dos solos (SILVA et al.2002).

Para a Geomorfologia a integração entre a erosão, transporte e sedimentação se faz necessária, pois são elementos integrantes do ciclo de erosão. A fase da Gliptogênese é o início do processo erosivo, ocorrendo simultaneamente com a Litogênese (Sedimentação), embora, em áreas diferentes (GUERRA, 1978).

Pode-se analisar a erosão a partir de dois aspectos, um tradicional como uma ação modificadora, exercida pela água corrente e outra como decomposição química feita pelas águas correntes (GUERRA, 1978).

Existem vários tipos de erosão resultantes da ação das águas: erosão acelerada; erosão elementar; erosão eólica; erosão diferencial; erosão em lençol; erosão em ravinas; erosão por salpico; erosão remontante; erosão pluvial; erosão glacial; erosão fluvial; erosão marinha. 
De acordo com o Dicionário Brasileiro de Ciências Ambientais (2002) e baseado no livro Terra: feições ilustradas, organizado por Suertegaray (2003), cada tipo de erosão pode assim ser definida:

Erosão acelerada - processo erosivo que ocorre, em geral, devido à ação antrópica e também de outros seres vivos, ocasionando um desequilíbrio ambiental em determinadas regiões. O desmatamento é uma das principais causas da erosão acelerada, provocando impactos ambientais tanto em áreas rurais como em áreas urbanas (Figura 1);

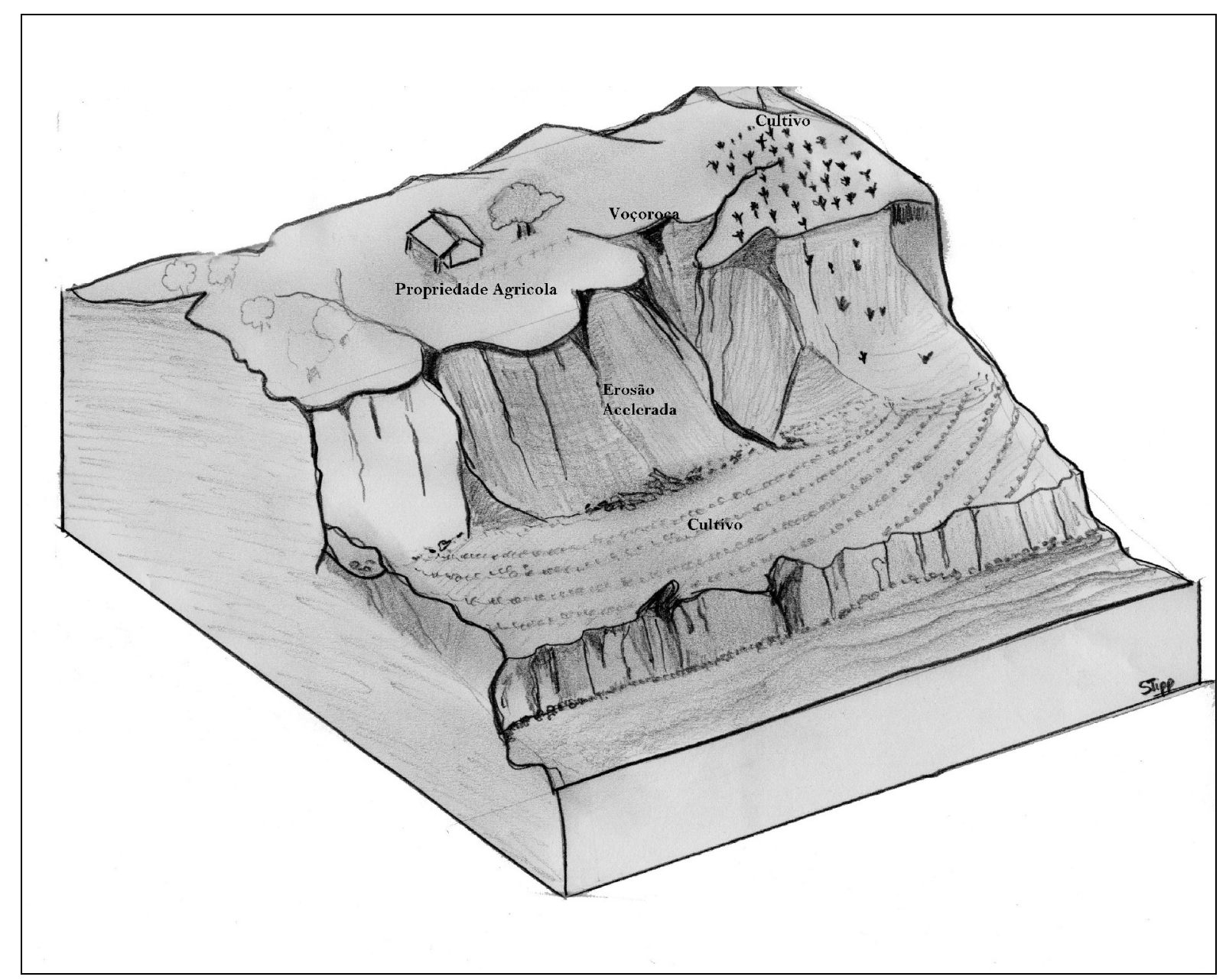

Figura 1. llustração de Erosão Acelerada. Des. STIPP, M. E. F., 2006. 
Erosão diferencial - É a que ocorre em função da diferente resistência dos materiais à ação dos agentes externos. Esse tipo de erosão pode dar origem à formas de relevo exóticas, acontecendo tanto em pequena como grande escala;

Erosão em lençol - erosão laminar - Aquela que ocorre devido ao escoamento difuso das águas. O escoamento das águas, ao se concentrar em sulcos, pode dar origem às ravinas, que podem evoluir para voçorocas (Figura 2);

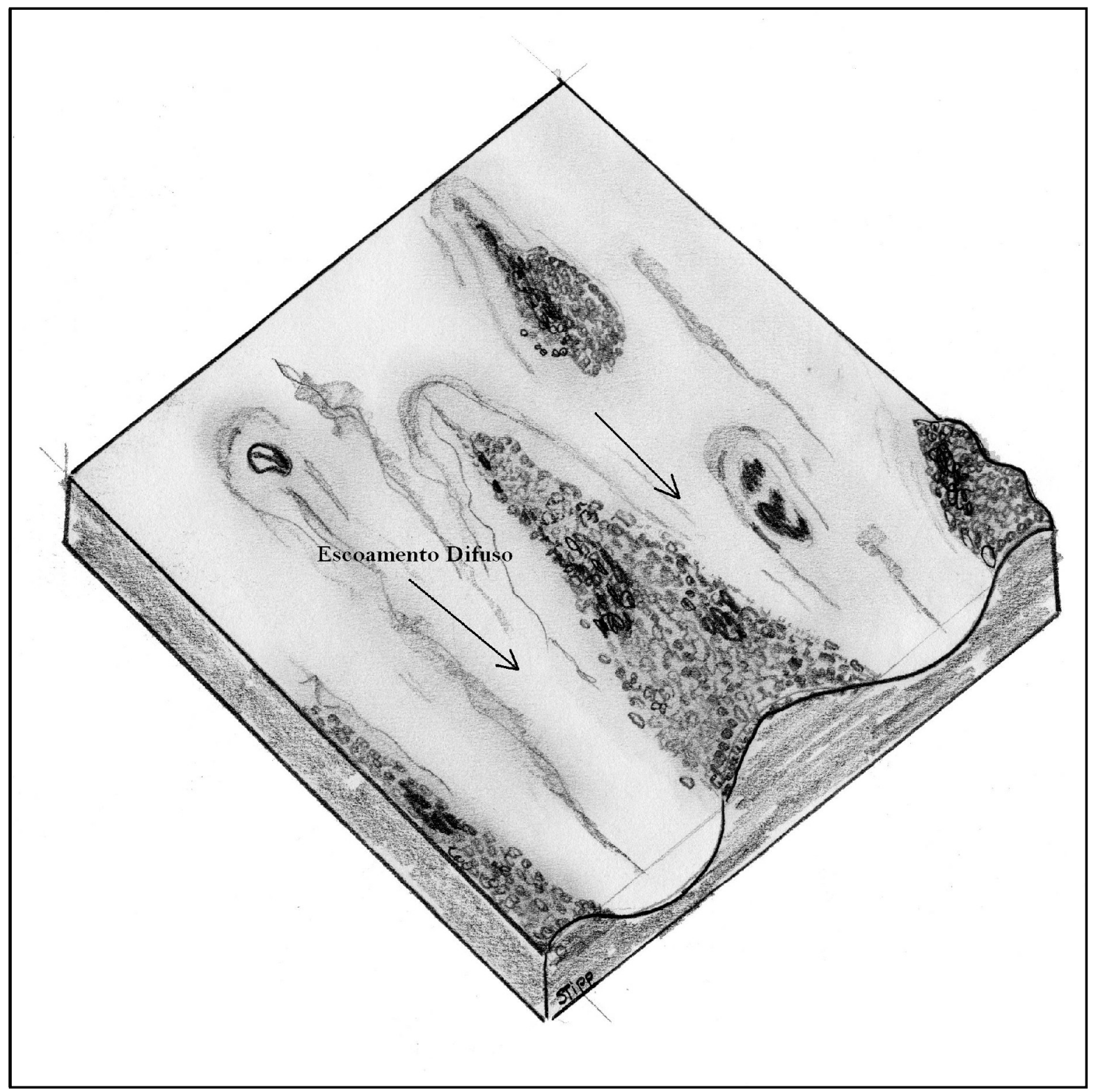

Figura 2. Ilustração de Erosão em Lençol. Des. STIPP, M. E. F., 2006. 
Erosão em ravinas - Evolução do escoamento em lençol (difuso), para um escoamento concentrado em sulcos. Uma vez estabelecido o escoamento concentrado nas ravinas, há uma tendência destas se alargarem e se aprofundarem, podendo dar origem a voçorocas (Figura 3);

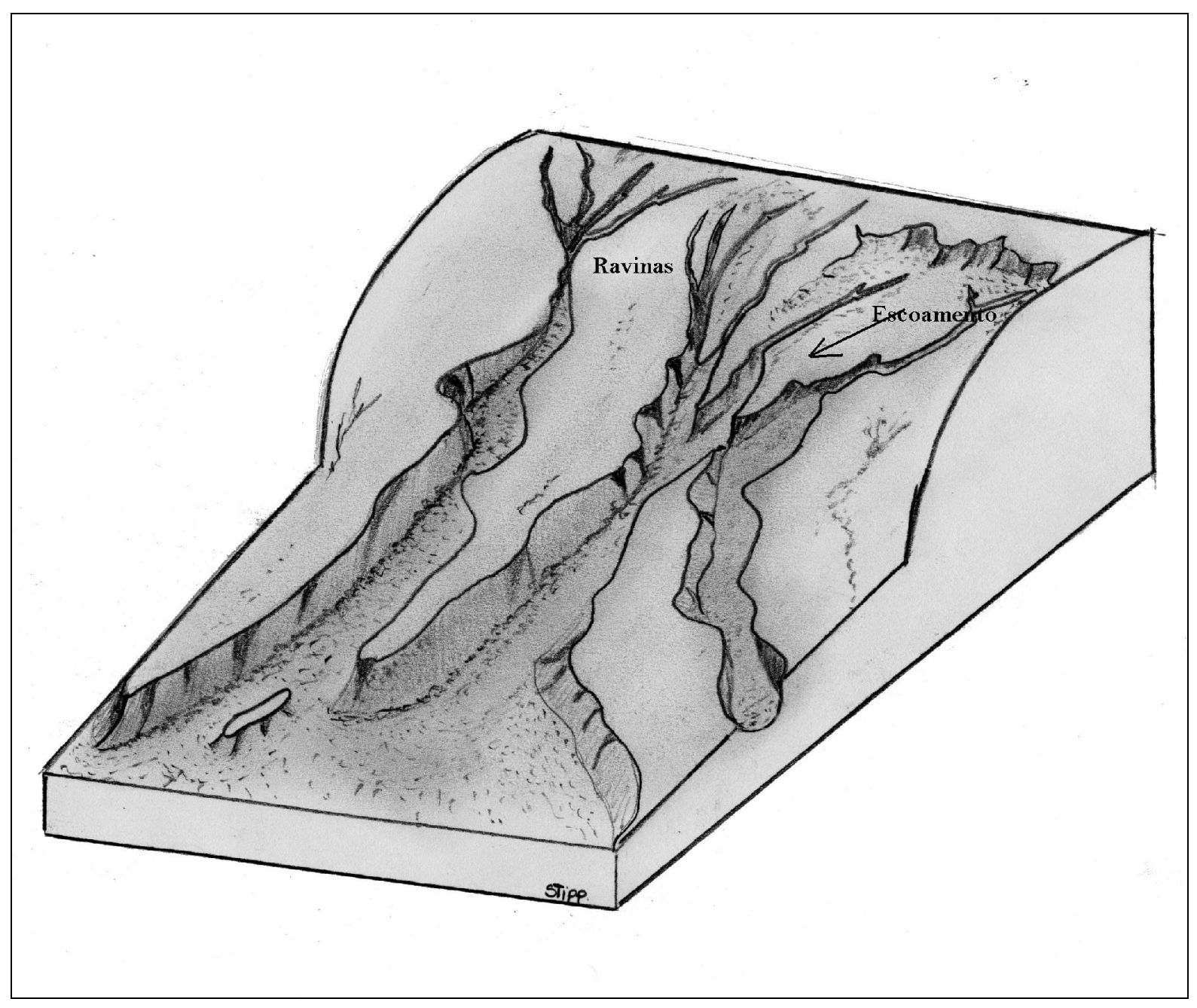

Figura 3. llustração de Erosão em Ravinas. Des. STIPP, M. E. F., 2006. 
Erosão fluvial - Trabalho executado pelas águas dos rios dentro do canal fluvial. Esse processo também é o responsável pela própria esculturação do canal e do vale fluvial. O processo envolve a retirada de material, o transporte e, quando cessa ou diminui a energia do agente transportador, os sedimentos são depositados, podendo formar terraços, ilhas fluviais, deltas, planícies aluviais (Figura 4);

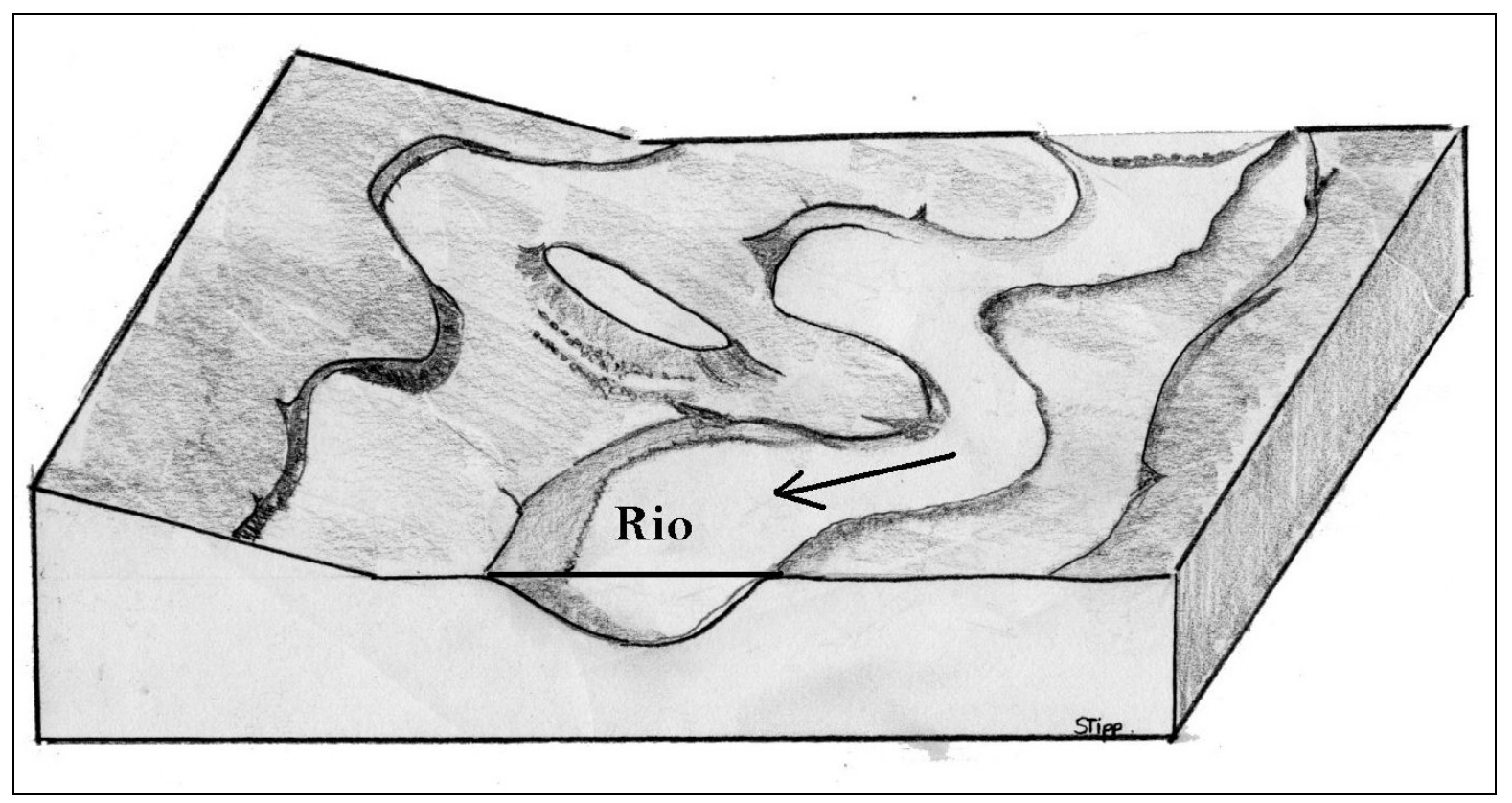

Figura 4. llustração de Erosão Fluvial. Des. STIPP, M. E. F., 2006. 
Erosão por salpico - erosão provocada pelas gotas de chuva, que ao baterem num solo, em especial o desprotegido pela vegetação, quebram os agregados e arremessam partículas em várias direções (inglês $=$ splash erosion) (Figura 5);

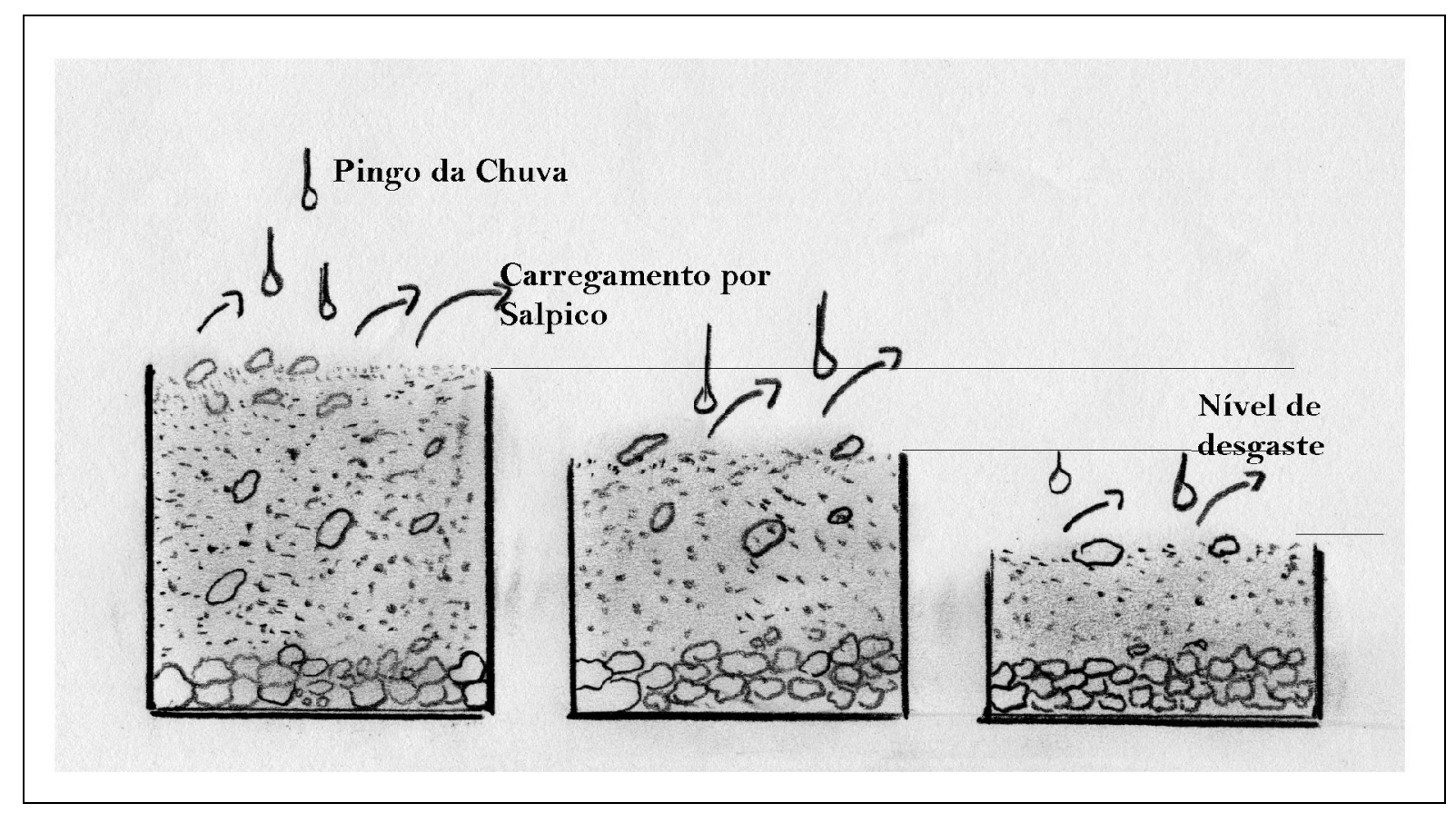

Figura 5. Ilustração de Erosão por Salpico. Des. STIPP, M. E. F., 2006. 
Erosão remontante - erosão fluvial, que se faz da foz dos rios em direção às nascentes, isto é, de jusante para montante, em função do nível de base. A erosão remontante é uma forma dos rios buscarem seu perfil de equilíbrio (Figura $6)$.

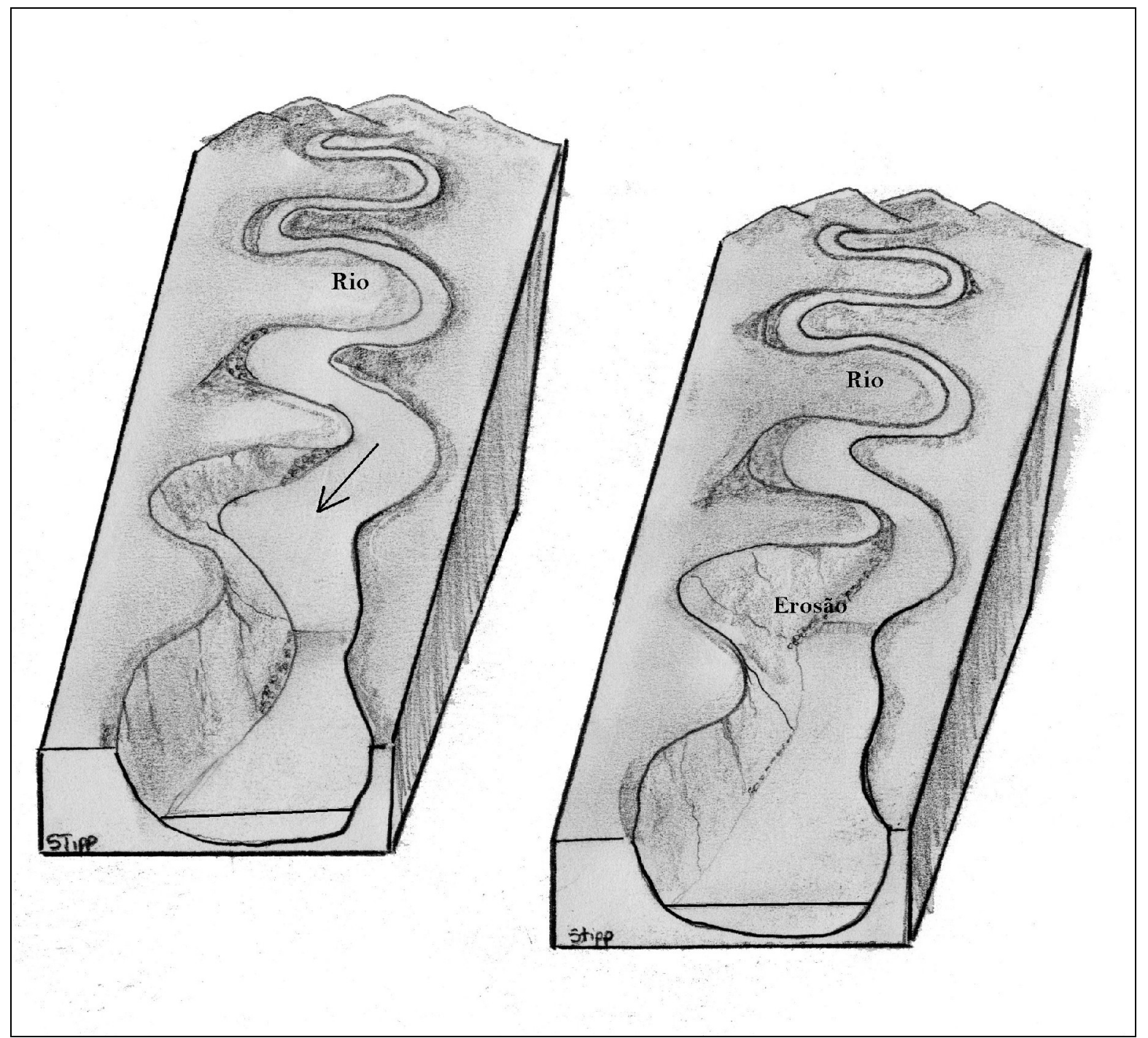

Figura 6. llustração de Erosão Remontante. Des. STIPP, M. E. F., 2006.

Essas erosões ocorrem continuamente. Segundo Guerra (1994) é um processo que se dá em duas fases: uma que constitui a retirada (detachment) de sedimentos, e outra que é o transporte do material. Quando não há energia suficiente para continuar o transporte esse material é sedimentado. Os mecanismos 
dos processos erosivos ocorrem a partir da fase de destruição e transporte dos materiais que não resistem às tais forças. Os processos erosivos básicos são os principais fatores que se necessitam conhecer para entender a erosão e suas conseqüências.Deve-se também analisar as características relativas a infiltração, armazenamento e geração de run-off (água de escoamento superficial);

Os processos de piping (túneis abertos, em subsuperfície, com diâmetros que variam de poucos centímetros até vários metros), splash (erosão por salpicamento, ocorrem basicamente, como resultado das forças causadas pelo impacto das gotas de chuvas) e a formação de crosta na superfície de solo. A partir desses processos pode-se entender como se originam os processos erosivos básicos.

Esses processos erosivos dependem de uma série de fatores controladores tais como : erosividade da chuva, propriedades do solo, cobertura vegetal e características das vertentes.A partir da ação desses fatores, ocorrem os mecanismos de infiltração de água no solo, armazenamento e escoamento em superfície e de subsuperfície. (GUERRA E CUNHA, 1994).

O processo se inicia com a água caindo em um solo em grande quantidade e o mesmo não conseguindo absorvê-la, começa a provocar o escoamento superficial, podendo dar origem a erosão - erosão em lençol - descrita pelo mesmo autor como erosão laminar, que se distribui pela vertente de maneira dispersa, não se concentrando em canais.

À medida que a velocidade aumenta, a água produz sulcos no solo, que começam a formar as ravinas - sulcos cavados nos terrenos, devido ao trabalho erosivo das águas de escoamento superficial que ao sofrerem certas concentrações passam a fazer incisões, passando do sheet-erosion para o rill-erosion, isto é, para erosão de ravinamento. Os aprofundamentos desses sulcos, devido à intensidade do escoamento superficial e subsuperficial ocasionam a formação de voçorocas, que são mais profundas e largas.

Outro fator que pode contribuir para o carreamento dos sedimentos, quando eles se apresentam soltos e com granulometria fina ou muito fina é o 
transporte eólico. Essas condições são mais intensas ao longo das praias que segundo Guerra (1994) são do tipo dissipativo a intermediário, de gradiente suave.

\subsubsection{Voçorocas}

Segundo Guerra (1978) voçoroca é a "escavação ou rasgão do solo ou da rocha decomposta, ocasionada pela erosão do lençol de escoamento superficial (...)”.

As voçorocas podem ser distinguidas dos sulcos por uma clara definição da profundidade e quando o processo erosivo começa a se alargar, chegando a atingir as proximidades do lençol freático, observando-se em suas laterais taludes às vezes quase verticais, bastante instáveis onde freqüentemente ocorre o deslizamento dos mesmos, provocando um soterramento do fundo anterior da voçoroca,desviando ou acumulando o fluxo de água.(STIPP.1978).

Segundo Hudson (1971), a causa básica do envoçorocamento é a quebra de um estado de equilíbrio ,meta-estável.Em Física diz-se que um corpo está em equilíbrio meta-estável quando ele somente volta à posição original se não for demasiadamente deslocado.Assim a formação desse tipo de erosão ocorre quando um escoadouro natural tem seu estado de equilíbrio meta-estável sensivelmente alterado.Normalmente um escoadouro resulta de um balanço, isto é, o tamanho do canal e a sua forma e gradiente são ajustados ao fluxo que ele tem que escoar. 


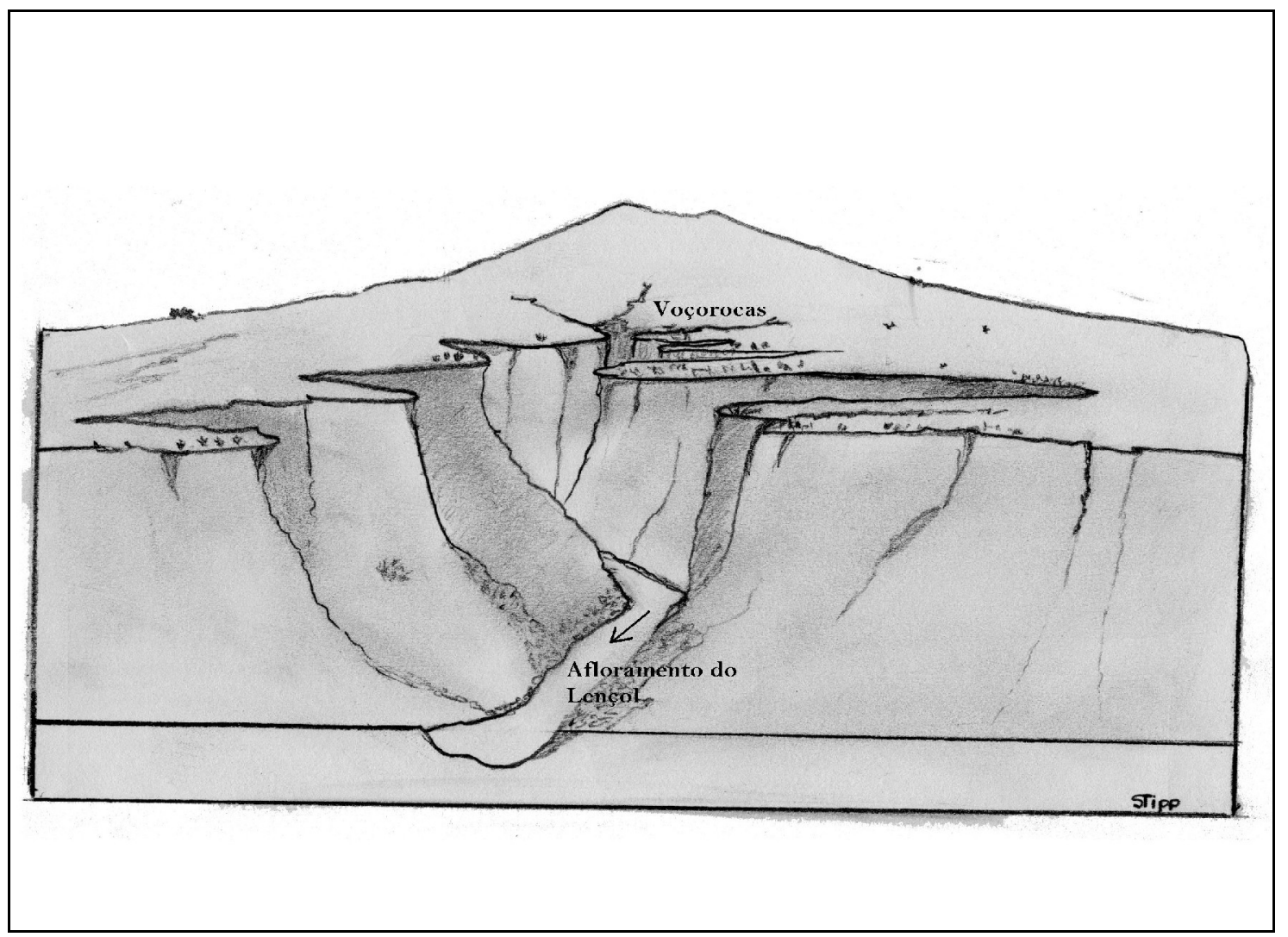

Figura 7. Ilustração de Erosão em Voçorocas. Des. STIPP, M. E. F., 2006.

De acordo com Silva (2002) voçoroca se define como o tipo erosão que pode ocorrer de duas formas: através da evolução das ravinas, ao alargamento e aprofundamento das mesmas e através do colapso do teto, em áreas onde o escoamento subsuperficial provoca formação de dutos em subsuperfície devido à dissolução de minerais, criando espaços vazios dentro do solo.(FIGURA 7)

Voçorocas são características erosivas relativamente permanentes nas encostas.Possuem alturas que podem ultrapassar $3 \mathrm{~m}$, com as encostas bastante íngremes, com o fundo bastante lavado, e muitas vezes com fluxo de água no seu interior, devido à ação de chuvas e/ou afloramento do lençol freático.São associadas com o processo de erosão acelerada, que modificam sensivelmente aa paisagens.

Para Zachar (1982) as voçorocas são as grandes responsáveis pelo carreamento dos sedimentos, e que em uma determinada região raramente ultrapassam $15 \%$ da área total. 
Segundo Guerra (1994) a ação antrópica através do mau uso da terra, devido à intensidade agrícola e as pastagens destinadas ao gado bovino, como também a característica climática da área em questão, com o fluxo pluviométrico, temperatura, as características do solo, são em geral os principais responsáveis pelo aparecimento das voçorocas. Elas começam a sofrer o processo de aprofundamento da base e nas laterais, ocorrendo um abatimento desse material, tanto das laterais como na parte superior, em direção ao topo da voçoroca, daí esse material é transportado muitas vezes e depositado nas partes mais baixas ou são transportados por canais fluviais que se localizem na base das mesmas.

Para conceituar voçoroca este trabalho se firmou mais na concepção de Guerra apud Glossário de Ciência dos Solos - 1987 (1994), "as voçorocas possuem mais de 0,5m de largura e de profundidade, podendo chegar a mais de $30 \mathrm{~m}$ de comprimento".

Algumas voçorocas têm sua origem a partir da ação do desmatamento que deixa o solo desprotegido sujeito à ação das intempéries, e os sedimentos são transportados pela ação do escoamento superficial e subsuperficial. Isso se dá através do fluxo contínuo em períodos de grande precipitação pluviométrica havendo grande remoção dos sedimentos, ocasionando o aprofundamento e alargamento de dutos que vão originar as voçorocas.

\subsubsection{Boçorocas}

Outra nomenclatura utilizada por alguns estudiosos no lugar de voçoroca é o termo "boçoroca".

Segundo Medeiros (2001) apud Salomão; Iwasa (1995) boçorocas são erosões lineares profundas, que atingem o lençol freático cujas águas passam a participar do processo erosivo, removendo mais acentuadamente o material que está sendo erodido.

Esse processo ocorre a partir da impermeabilidade do solo, devido à ação antrópica e conseqüentemente do escoamento superficial; construções de 
sistemas de drenagem inadequados; efluentes líquidos, com poder químico altamente corrosivo; exposição do solo, pela retirada da vegetação original; obras que desnudam o solo, expondo seus horizontes.

\subsection{AÇÃO dOS VENTOS}

A partir da diferença de pressão atmosférica, estabelece-se uma corrente de ar, que é o vento, cuja direção é direcionada da área de alta pressão atmosférica, para a área de baixa pressão atmosférica. Quanto maior for essa diferença, tanto maior será a força do vento. Diferentes fatores físicos podem influenciar na sua velocidade, como o atrito contra a superfície, ou pela formação eventual de correntes aéreas de convecção. A ação energética eficaz do vento nos trabalhos construtivos e destrutivos da superfície terrestre depende principalmente da sua velocidade, sendo o trabalho mais efetivo, quanto mais constante for o vento.

Segundo Guerra (1978), a erosão pelo vento, chamada de erosão eólia ou eólica, é o trabalho realizado através da deflação e da corrosão. É mais evidente nas regiões desérticas, nas zonas semi-áridas, ou ainda nas zonas litorâneas. A erosão eólica dá origem a formas típicas e peculiares.

A desagregação de origem térmica é mais importante que a decomposição química dos minerais, e isto favorece o trabalho de deflação do vento.

Segundo Leinz e Amaral (1978), os efeitos diretos do vento podem ser classificados em: a) destrutivos; b) transportadores e c) construtivos.

Os ventos por si só são incapazes de produzirem a erosão. Seus efeitos destrutivos limitam-se aos danos às árvores, às formações rochosas e construções humanas. Devido ao seu poder de carregar partículas minúsculas de areia, o impacto dessas contra as rochas ou construções humanas, exercem o trabalho de esculturação, desgastando bastante os materiais que se interpõem no seu caminho. Esse trabalho torna-se mais visível a partir da regularidade e intensidade do vento. 
O material desgastado pelo vento é também incorporado e transportado, fazendo o papel do desgastador. Quando ele é formado por materiais muito heterogêneos, o material mais rígido permanece, determinando formas geométricas e exóticas nas rochas.

Quando o vento predomina em uma certa direção, formam-se sulcos orientados segundo esse alinhamento. Leinz e Amaral (1978) chamam essa atividade de corrosão, terminologia adotada para esse tipo de erosão.

Os efeitos transportadores dependem da velocidade do vento e do tamanho das partículas. $O$ transporte pode ser efetuado de várias maneiras: por suspensão, onde o material fica suspenso no ar, geralmente partículas muito finas (poeira); por rolamento, que devido a intensidade do vento rola o material pela superfície; e por saltos ao longo do percurso, que projetam o material em espaços irregulares, dependendo da rajada de ventos.

Os efeitos construtivos ocorrem quando diminui a velocidade do vento,iniciando-se aí a sedimentação das partículas que estavam em suspensão e que foram transportadas. Essas partículas são sedimentadas de acordo com o seu peso e tamanho,primeiro os grãos maiores seguidos dos grãos menores.

Esses depósitos são denominados de depósitos eólicos, onde o vento é constante numa determinada direção, havendo uma deposição contínua, dando origem a elevações de forma regular e característica que recebem o nome de dunas.

\subsection{Outras Modalidades de Degradação Ambiental: Desertificação e ArenizaÇÃo}

\subsubsection{DeSERTIFICAÇÃo}

O termo desertificação surge pela primeira vez em 1949, em um estudo francês sobre o crescimento das áreas de savanas na África tropical e subtropical. Em 1978, uma conferência da Organização das Nações Unidas sobre o 
tema define o fenômeno como a "diminuição ou destruição do potencial biológico da terra, podendo levá-la a condições do tipo desértico". Em 1990, restringe-se a definição a áreas de clima árido, semi-árido e sub-úmido.

A desertificação começou a ser discutida pela comunidade científica nos anos 30, decorrente de um fenômeno ocorrido no meio oeste americano conhecido como Dust Bowl, ("bacias de poeiras") onde intensa degradação dos solos afetou uma área de cerca de $380.000 \mathrm{Km}^{2}$ nos estados Oklahoma, Kansas, Novo México, e Colorado.

Este fenômeno motivou os cientistas a iniciarem um conjunto de pesquisas e a mencionar tal processo como sendo o da desertificação, isto é, a formação de condições de tipo desértico em áreas de clima semi-árido ou subúmido. Desde essa época os pesquisadores vêm dando atenção aos fenômenos que ocorrem nessas regiões de todo mundo, principalmente naquelas sujeitas às secas periódicas.

A constatação mais evidente foi de que nestas áreas, por suas características físicas e limitações naturais, concentram-se as populações mais pobres do planeta que estão sujeitas aos maiores níveis de degradação ambiental.

Muitos estudiosos atribuíram a desertificação ora a processos naturais, ora a processos induzidos pelos homens.Num solo degradado, se não forem adotadas medidas que eliminem as causas dessa degradação pode tornar-se desertificado, isto é, ter a sua fertilidade exaurida, além de perder a capacidade de retenção de água indispensável ao desenvolvimento da vegetação.

Essa polêmica de concepções, longe de ser puramente acadêmica, teve, e ainda tem, importância prática significativa, pois pode influenciar tanto na formulação de políticas como na destinação de investimentos.

Para Silva (2002) Desertificação se constitui no "Fenômeno de transformação de áreas anteriormente vegetadas em solos inférteis devido a ações antrópicas, como mau uso e exploração da terra”. Pode também ocorrer por processos naturais, devido ao ressecamento climático, que é uma diminuição de umidade por longos períodos de tempo. 
Desertificação é a degradação de terra nas zonas áridas, semiáridas e sub-úmidas secas, resultantes de vários fatores, incluindo as variações climáticas e as atividades humanas (Decreto $n^{\circ} 2.741$, de 20 de agosto de 1998).

Aubreville (1949) pioneiro das investigações na África equatorial, assinala a ação antrópica como desencadeadora desse processo. A Conferência Mundial sobre Desertificação ocorrida em Nairobi (Quênia), em 1977, manteve a mesma afirmação.

A partir da classificação de Harold E. Dregne, Conti (2003) apresenta critérios ambientais para estabelecer categorias de intensidade de desertificação (Figura 8). 


\begin{tabular}{|c|l|c|}
\hline GRAU & \multicolumn{1}{|c|}{ CARACTERIZAÇÃo } & \% DE INCIDÊNCIA \\
\hline Fraca & $\begin{array}{l}\text { Pequena deterioração da } \\
\text { cobertura vegetal e dos } \\
\text { solos }\end{array}$ & 18,0 \\
\hline Moderada & $\begin{array}{l}\text { Grande deterioração da } \\
\text { cobertura vegetal e } \\
\text { surgimento de nódulos de } \\
\text { areia. Indícios de } \\
\text { salinização dos solos. } \\
\text { Voçorocamento. }\end{array}$ & \\
\hline Severa & $\begin{array}{l}\text { Severa ampliação das } \\
\text { áreas sujeitas a } \\
\text { voçorocamentos e } \\
\text { surgimentos de dunas. } \\
\text { Avanço da erosão eólica. }\end{array}$ & \\
\hline Muito Severa & $\begin{array}{l}\text { Desaparecimento quase } \\
\text { completo da biomassa. } \\
\text { Impermeabilização e e } \\
\text { salinização intensa dos } \\
\text { solos. }\end{array}$ \\
\hline
\end{tabular}

Figura 8. Quadro de intensidade da desertificação.Fonte: Dregne, 1977 apud Conti, 2003.

Pode-se utilizar também o termo Desertificação para designar a extensão de paisagens e formas tipicamente desérticas, em áreas semi-áridas e subúmidas, como conseqüência da ação humana (DREGNE, 1977 APUD CONTI, 2003).

Evidencia-se abaixo um quadro (Figura 9) onde esse mesmo autor esquematizou uma classificação para desertificação que aparece dividida em duas modalidades: natural (ou climática) e antrópica (ou ecológica). 


\begin{tabular}{|c|c|c|}
\hline & CLIMÁTICA & ECOLÓGICA \\
\hline Conceito & $\begin{array}{l}\text { Diminuição de água no sistema } \\
\text { natural }\end{array}$ & $\begin{array}{l}\text { Criação de condições } \\
\text { semelhantes às dos desertos }\end{array}$ \\
\hline Avaliação & Índices de aridez & Empobrecimento da biomassa. \\
\hline Indicadores & $\begin{array}{l}\text { Elevação da Temperatura média; } \\
\text { Agravamento do déficit hídrico dos } \\
\text { solos; } \\
\text { Aumento do escoamento } \\
\text { superficial (torrencialidade); } \\
\text { Intensidade da erosão eólica; } \\
\text { Redução das precipitações (perda } \\
\text { de húmus); } \\
\text { Aumento da amplitude térmica; } \\
\text { Diminuição da umidade relativa } \\
\text { (UR) do ar. }\end{array}$ & $\begin{array}{l}\text { Desaparecimento de árvores e } \\
\text { arbustos lenhosos } \\
\text { (desmatamento); } \\
\text { Aumento das espécies } \\
\text { espinhosas (xerófiticas); } \\
\text { Elevação do albedo, ou seja, } \\
\text { maior refletividade na faixa } \\
\text { infravermelho. } \\
\text { Mineralização do solo em } \\
\text { encosta com mais de } 20^{\circ} \text { de } \\
\text { inclinação (perda de húmus); } \\
\text { Forte erosão do manto } \\
\text { superficial (voçorocamento); } \\
\text { Invasão maciça das areias. }\end{array}$ \\
\hline Causas & Mudanças nos padrões climáticos & $\begin{array}{l}\text { Crescimento demográfico e } \\
\text { pressão sobre os recursos. }\end{array}$ \\
\hline Exemplos & $\begin{array}{l}\text { Oscilações dos cinturões áridos } \\
\text { tropicais durante as glaciações } \\
\text { quaternárias. }\end{array}$ & $\begin{array}{l}\text { Desertificação das regiões } \\
\text { periféricas tropicais durante as } \\
\text { glaciações. } \\
\text { Pontos de desertificação no } \\
\text { sul do Brasil (PR, RS). }\end{array}$ \\
\hline
\end{tabular}

Figura 9. Quadro de Classificação da Desertificação Natural e Antrópica. Fonte: Conti (2003).

Suertegaray apud Houérou (1987), utiliza o termo Desertificação para descrever a degradação de vários tipos de formas de vegetação, incluindo também as Florestas Sub-úmidas e úmidas, não sendo comparada com desertos na sua forma física ou biológica.Menciona que no Brasil o tema "Desertificação" é bastante controvertido e não têm conotação apenas local, são áreas cujas tendências climáticas tendem para o ressecamento. Suertegaray apud AB'Saber (1987) afirma que essa temática trata-se de uma questão de âmbito nacional, com limitada produção científica. Segundo Ab'Saber (1977) pairam sérias dúvidas sobre os processos de Desertificação antrópica, como também sobre a expansão do estado de semi-aridez, devido às alterações climáticas. 


\subsubsection{ARENIZAÇÃO}

Segundo o Dicionário Brasileiro de Ciências Ambientais (2002) Arenização é o processo de formação de areais, no sudoeste do Rio Grande do Sul. Corresponde ao retrabalhamento das areias, devido à sua constante mobilidade, que corresponde à transformação de depósitos aproximadamente inconsolidados em areais.

Segundo o pesquisador Archimedes Peres Filho do IG (2003), a arenização é provocada pelo uso inadequado da terra, decorrente da ação do Homem, compreendendo manchas expostas, constituídas de areais (grãos de quartzos), localizadas em diversas áreas do território brasileiro.

O conceito de arenização foi aprofundado por Suertegaray (1987) como "deficiência da cobertura vegetal devido à intensa mobilidade dos sedimentos por ação das águas e ventos".

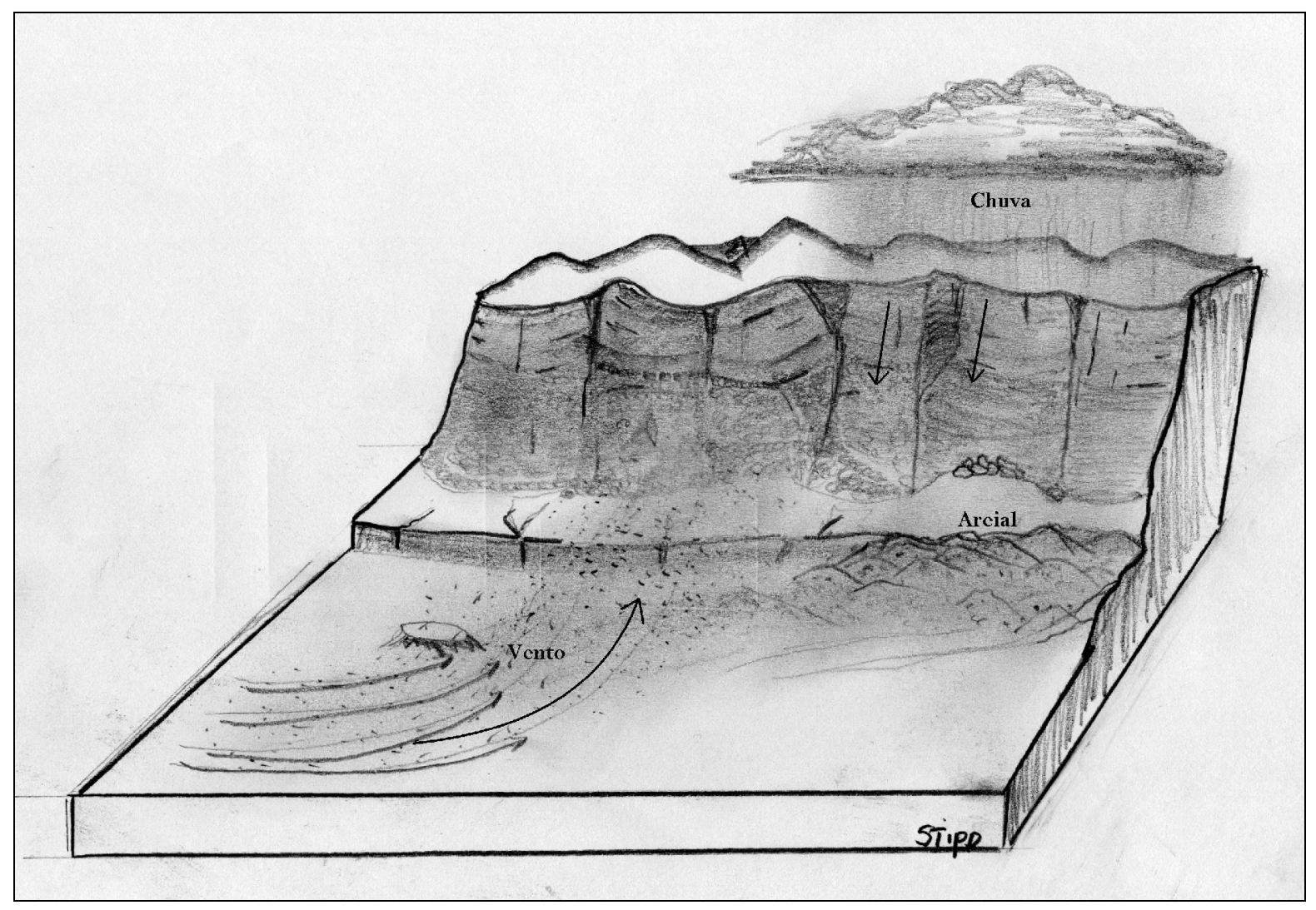

Figura 10. llustração de Arenização. Des. STIPP, M. E. F., 2006. 
O retrabalhamento de depósitos arenosos de baixa consolidação, que contribuem para a dificuldade de fixação da cobertura vegetal, ocorre devido a movimentação dos sedimentos pela ação dos agentes erosivos (SUERTEGARAY, 1987).

Segundo essa autora, a arenização está relacionada ao clima úmido, e sua degradação está fundamentalmente relacionada com a abundância de água.

Em seu estudo no Rio Grande do Sul sobre as formações dos areais, ainda, destaca o substrato no arenito da Formação Botucatu (Era Mesozóica), sobre essa formação assentam-se inúmeros depósitos arenosos não consolidados, que foram criados através da ação erosiva da água e do vento, durante a Era Cenozóica (Pleistoceno e Holoceno). Para a interpretação utilizou-se de referências geomorfológicas associadas à dinâmica hídrica e eólica. Em seus primeiros estágios, o movimento se inicia a partir dos processos hídricos, com a formação de ravinas e voçorocas, ligadas à ação intensiva de chuvas e ventos, onde ocorre o seu desenvolvimento a partir da erosão regressiva - alargando as bordas à jusante dessas ravinas e voçorocas.

Nesse local formam-se depósitos arenosos em forma de leques, que com o tempo vão agrupando-se e dão origem a um areal. De acordo com Suertegaray (1987) o vento atua sobre essas areias, em todas as direções, permitindo a ampliação desse processo.

\subsubsection{A Problemática da Arenização}

Segundo vários autores da área, dentre eles Conti e Suertegaray, as principais causas da degradação do solo e a formação de areais derivam do uso ou manejo inadequado dos recursos da terra. Dentre os usos mais nocivos ao ambiente pode-se citar: 
- uso abusivo dos solos tanto na agricultura de grande escala quanto na de pequena escala;

- cultivo em terras inapropriadas tais como encostas íngremes, ecossistemas e matas remanescentes, etc.;

- pecuária extensiva ;

- desmatamento em áreas com vegetação nativa, áreas de preservação , matas ciliares , etc.;

- práticas inapropriadas de conservação de solo,sistemas de drenagem como irrigação sem as devidas orientações técnicas, ausência de formas de drenagem;

- mineração;

- Ação erosiva das águas e dos ventos

O crescimento da população contribui para a exploração dos recursos naturais, para além de sua capacidade. $O$ aumento da população assim como a demanda por alimentos, energia e outros recursos naturais, vem provocando importantes impactos ambientais exaurindo os recursos naturais.

\subsubsection{Conseqüências da Arenização}

De acordo com pesquisadores dessa temática, entre eles Conti e Suertegaray, as conseqüências da arenização podem ser divididas em 4 (quatro) grandes grupos, mencionados a seguir:

\section{Sociais}

- Abandono das terras por parte das populações mais pobres (migrações) 
- Diminuição da qualidade de vida, aumento da mortalidade infantil e diminuição da expectativa da vida da população.

- Desestruturação das famílias como unidades produtivas

\section{Econômicos e Institucionais}

- Queda na produção e produtividade agrícola

- Diminuição da renda e do consumo das populações

- Desorganização dos mercados regionais e nacionais

- Desorganização do estado e inviabilização de sua capacidade de prestação de serviços

- Instabilidade política

\section{Urbanas}

- Crescimento da pobreza urbana devido as migrações

- Desorganizações das cidades, aumento do desemprego e da marginalidade

- Aumento da poluição e problemas ambientais urbanos

\section{Recursos Naturais e Clima}

- Perda de biodiversidades (flora e fauna)

- Perda de solos por erosão

- Diminuição por disponibilidade efetiva de recursos hídricos devido ao assoreamento de rios e reservatórios 
- Aumento das secas edáficas por incapacidade de retenção de água dos solos

- Aumento da pressão antrópica em outros ecossistemas

A degradação das terras causa sérios problemas econômicos. Isto se verifica principalmente no setor agrícola, com o comprometimento da produção de alimentos.

Além do enorme prejuízo causado pela quebra das safras e diminuição da produção, existe o custo quase incalculável de recuperação da capacidade produtiva de extensas áreas agrícolas e da extinção de espécies nativas, algumas com alto valor econômico e outras que podem vir a ser aproveitadas pela agropecuária, inclusive no melhoramento genético, ou nas indústrias farmacêuticas, químicas e outras.

Os problemas sociais estão intimamente relacionados aos custos econômicos. Segundo estimativas das Nações Unidas uma dieta nutricionalmente adequada para a crescente população mundial implica na triplicação da produção de alimentos ao longo dos próximos 50 anos, meta difícil de se alcançar mesmo sobre condições favoráveis. Dentro desta perspectiva pode-se esperar um agravamento significativo no quadro de desnutrição, falência econômica, baixo nível educacional e concentração de renda e poder que já existem tradicionalmente em muitas áreas propensas à problemática dos países pobres ou em desenvolvimento.Sobre estas condições vivem milhares de pessoas com pouca chance de se enquadrar em uma economia cada vez mais moderna e globalizada.

A falta de perspectiva leva a população a migrar para os centros urbanos.

Procurando condições mais favoráveis de sobrevivência, estes migrantes tendem a agravar os problemas de infra-estrutura (transporte, saneamento, abastecimento, entre outros) já existentes nos centros urbanos. Verifica-se também um aumento nos níveis de desemprego e violência urbana. 
Os impactos sociais podem ser caracterizados pelas importantes mudanças sociais que a crescente perda da capacidade produtiva provoca nas unidades familiares.

Quando esse impacto ocorre no sítio urbano ocorre um agravamento das áreas de riscos em casos de chuvas excessivas, já que esses espaços se tornam propensos ao processo de favelização, devido à queda do valor imobiliário dessas terras. 


\section{LOCALIZAÇÃO DA ÁREA DE ESTUDO}

O município de Paranavaí é cortado ao sul pelo trópico de

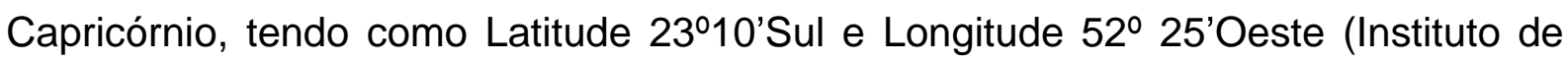
Terras, Cartografia e Florestas - ITCF 1982).

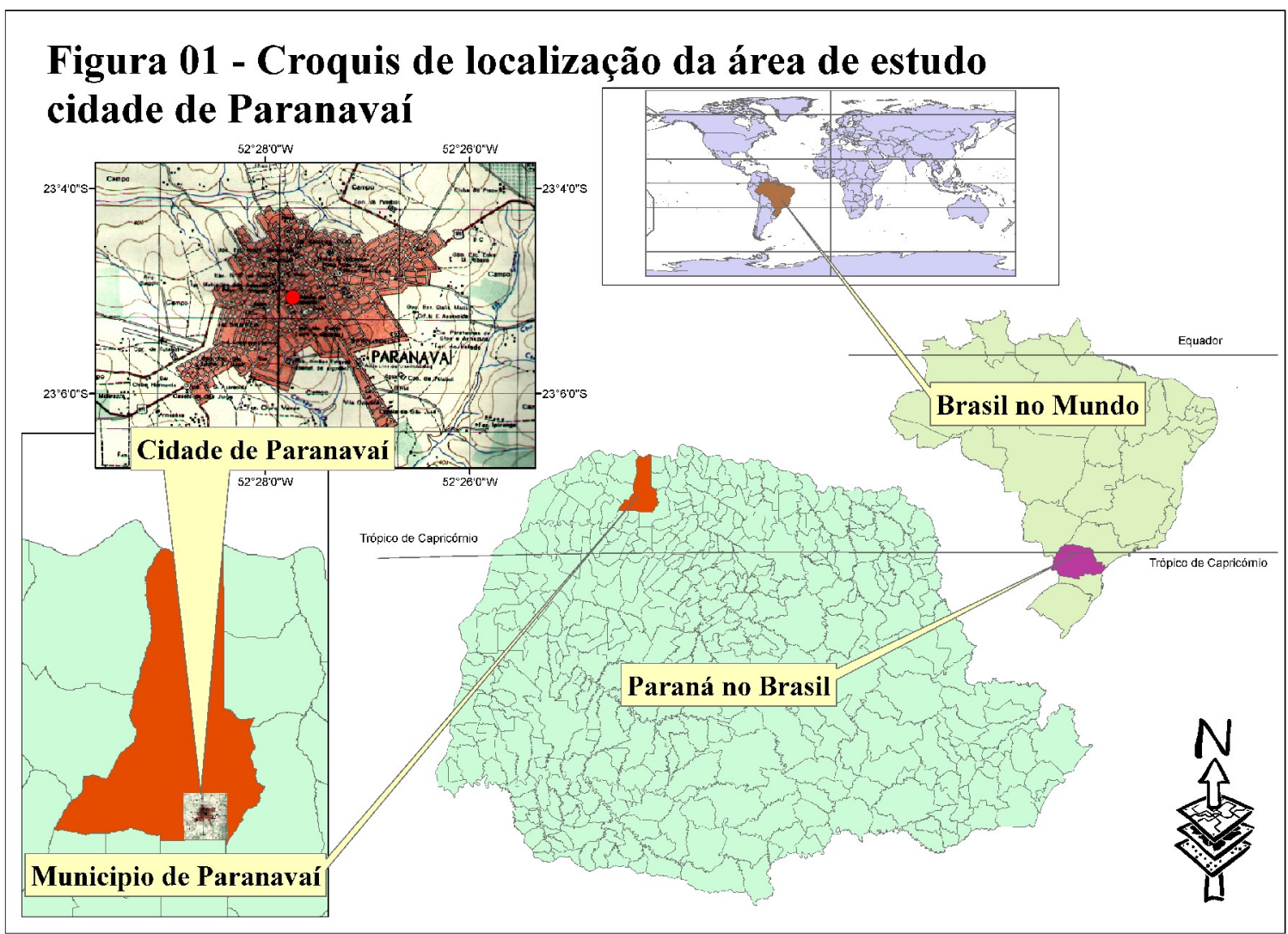

Figura 11. Mapa de Localização da Área de Estudo. Autor: STIPP, M. E. F., 2006.

A área urbana do Município de Paranavaí - Pr, se situa geogràficamente no Terceiro Planalto (MAACK, 2002) na região noroeste do Estado do Paraná, entre as nascentes dos Ribeirões Paranavaí e Suruquá, afluentes do Rio Ivaí. 


\section{HISTÓRICO DO MUNICÍPIO DE PARANAVAí}

Paranavaí surgiu de um processo de ocupação da porção norte do território paranaense, que se iniciou nos anos 20 intensificando substancialmente nos anos 40 no séc. $X X$, devido a expansão do café paulista.

Com a construção da estrada de ferro, veio a facilidade de ocupação da área, que de acordo com a história foi concedida a várias companhias de estrada de ferro terminando a concessão em 1917 nas mãos da Companhia Brasileira de Viação e Comércio (BRAVIACO), Lei № 1909 de 18 de fevereiro de 1920 e no contrato de 23 de agosto de 1920.

A área foi delimitada pelos rios Paraná, Paranapanema e Ivahy que mais tarde se transformou na "Colônia de Paranavaí".

Essa área ficou conhecida pelos crimes, assassinatos e elevado investimento que recebeu para a fundação da Fazenda Velha Brasileira.O núcleo central da Fazenda corresponde hoje ao perímetro urbano da cidade de Paranavaí.

Junto à sede da fazenda foi fundado o Distrito de Montoya, pertencente à Comarca de Tibagy, por Geraldo Rocha, Landulfo Alves de Almeida e Humberto Alves de Almeida, diretores da BRAVIACO.

Conforme Frutoso Joaquim de Salles: Em 1929 a Brasileira já estava instalada e o pessoal (migrados do nordeste pela Companhia) vinha aqui trabalhar, derrubar mato. Eram 1.800 alqueires, sendo mil alqueires em café e 200 alqueires de invernada. Até 1930, havia na fazenda cerca de 1.400 famílias de trabalhadores que habitavam casas em diversas colônias nas proximidades da sede (Política Local - Um Estudo de Caso _ Paranavaí 1952-1982 - José Carlos de Alcântara. 1987).

A Companhia Brasileira (BRAVIACO) possuía máquina de beneficiar arroz, serraria, uma frota de 25 caminhões, 60 mulas cargueiro, armazém, farmácia e mais 1.000 casas cobertas de zinco. Inexistia qualquer ligação por estradas com o resto do Paraná.O acesso à Fazenda Brasileira se fazia através de um picadão partindo do Porto São José, no Rio Paraná e de outro que ligava a Fazenda ao Porto Ceará, no Rio Paranapanema, e dali a Presidente Prudente no Estado de São Paulo. A comunicação com o Tibagy, sede da Comarca e outras cidades do Paraná 
era feita através de Presidente Prudente. Desta cidade os viajantes tomavam o trem até Ourinhos e depois entravam no Paraná, para seguir a cavalo até Tibagy.

Em pleno desenvolvimento, o empreendimento é atingido pelo Decreto no 300, de 03 de novembro de 1930, assinado pelo General Mario Tourinho, chefe do Governo Provisório do então Estado do Paraná. Em sua exposição de motivos, considerava que as cláusulas do contrato firmado em 23 de agosto de 1920 com a Companhia Estrada de Ferro São Paulo - Rio Grande, e por estar cedido à Companhia Brasileira de Viação e Comércio, não foram cumpridas e, conseqüentemente, decreta sua rescisão, bem como de todos os atos conseqüentes do mesmo, sendo, declarados nulos e sem efeito todos os títulos de domínio expedidos pela companhia.

Em razão deste Decreto foram anulados todos os títulos de terras expedidos em favor da BRAVIACO, inclusive os da Gleba Pirapó.

Em 08 de abril de 1931, pelo Decreto № 800 o General Mario Tourinho, interventor Federal do Estado, objetivando solucionar o problema da colonização das terras paranaenses por famílias nacionais, bem como por estrangeiros que espontaneamente quisessem concorrer para o progresso do Paraná, limitou a concessão de grandes áreas em 200 hectares de terras que cada pessoa ou família poderia obter,que foi concedido a título de venda pelo Estado. Em conseqüência desses atos a Fazenda Brasileira foi sendo abandonada e após 1932 desocupada, quando esteve na mesma o Tenente Coronel Palmiro da Polícia Militar do Estado do Paraná e com ele se retirou Landulfo Alves de Almeida, Diretor da BRAVIACO.

Houve um abandono geral, casas e ranchos foram quase todos destruídos e incendiados,uma decadência total, pois os trabalhadores se evadiram, veículos foram abandonados, casas invadidas pelo mato e plantações perdidas. Dos aproximados 6.000 habitantes e 1.400 famílias, permaneceram as famílias de JOSÉ FIRMINO DA SILVA, MANOEL PAULINO DE SOUZA, JOÃO CLAREANO DA SILVA E OLINTO BAHIANO, e mais os peões FRUTUOSO JOAQUIM SALLES, VELHO CABOCLO E MARINS, que usufruíram as instalações e plantações abandonadas. 
Em 1937 surge no local vindo de Campo Mourão a Família de Antonia Fabricia Vieira e em 1938 vindo do Mato Grosso o Tenente Telmo Ribeiro.

Segundo Ulisses Faria Bandeira ocorreu em 1942 a demarcação da gleba para a localização de famílias nacionais na colônia batizada com o nome de Paranavaí, marco inicial do povoamento da vasta região que vai desde a divisa com as terras da Companhia de Terras Norte do Paraná, até o Rio Paraná entre os rios Paranapanema e Ivaí.

O agrimensor Ulisses Faria Bandeira, demarcou a primeira via pública da colônia em 1942. Trabalhava em Londrina com seu tio Francisco Almeida Faria, engenheiro encarregado da Inspetoria de Terras do Estado. Ulisses fixou residência em Paranavaí em 1944.

Para administrar a colônia, o Governo do Estado, através do Departamento de Geografia, Terras e Colonização, nomeou Hugo Doubek, que chegou em Paranavaí em 1943.

Os primeiros lotes foram solicitados à Inspetoria Estadual em março de 1943.

As terras eram vendidas pelo Governo e as propriedades rurais eram de dimensões variadas, conforme sua localização mais próxima ou mais distante em relação à sede da colônia. Porém os primeiros colonos chegaram somente em setembro, devido à escassez de transportes.

Os caminhões cobravam de 1.200 a 1.500 cruzeiros por uma viagem de Londrina à Paranavaí.

Os requerentes iam chegando aos poucos e as casas da antiga Fazenda Brasileira, eram desmanchadas e montadas novamente em outros locais para os colonos.

Em 1944 já existiam aproximadamente 80 casas e 500 habitantes.Nesse mesmo ano foi feita a demarcação da cidade pelo engenheiro Francisco Almeida Faria e denominado o local de "Colônia Paranavaí", neologismo formado pela junção dos nomes dos rios Paraná e Ivaí. 
A colônia Paranavaí foi dividida em 30 glebas e cada uma tinha aproximadamente 15.000 alqueires, sobre os quais houve tentativa de grilagem, repelidas por homens do Estado, tendo à frente o sargento José Marcelino de Souza, delegado de polícia.

Entretanto fatos sangrentos ocorreram no período, pela disputa da posse da terra e isso não evitou que a população aumentasse rapidamente. Os colonos se dedicavam ao plantio de cereais, café e pecuária.

Em 1947, em franco desenvolvimento, a Colônia torna-se Distrito do Município de Mandaguari, adotando apenas o nome de Paranavaí.

A criação do Município deu-se com a Lei no 790 de 14 de novembro de 1951, sua instalação ocorreu em 14 de dezembro de 1952 e foi elevada a comarca em 1 de março de 1954.

Uma das peculiaridades desta ocupação foi o loteamento de áreas rurais, também em parcelas menores que atraíram expressivos contingentes de pequenos produtores. Tal fato, associado à expressiva necessidade de mão-de-obra das grandes áreas cafeeiras, produziu uma dinâmica populacional que viabilizou a sustentação de numerosos centros urbanos. As primeiras áreas a serem ocupadas nesse processo ficavam à nordeste, o chamado Norte Pioneiro, seguiu-se a ocupação do Norte Novo e, seguindo em direção a noroeste, a ocupação alcançou o Norte Novíssimo que tem Paranavaí como cidade pólo.

Esse processo de ocupação do Norte do Paraná se deu de forma muita rápida, ou seja, em menos de 40 anos essa área de 71.637 quilômetros quadrados, cerca de $36 \%$ do território paranaense transformou-se de mata densa em uma região que em 1960 contava com cerca de 1.843 mil habitantes, distribuídos em 172 cidades.

Segundo Ruy Wachowicz, no livro História do Paraná (2002), a partir da década de 30 existiram vários motivos para essa ocupação se dar de forma tão rápida e intensa, destacando-se como principais os seguintes:

- A situação da economia nacional no contexto internacional, com a intervenção inglesa para 
estudar a produção de algodão no Brasil, a fim de suprir as indústrias de tecelagem na Inglaterra;

- A evolução da cafeicultura paulista nesse período;

- A grande extensão de terras de excepcional qualidade e fertilidade - as terras roxas do Norte do Paraná;

- A necessidade estratégica de ligação de Mato Grosso ao litoral.

Após a Segunda Guerra Mundial instalou-se no Norte do Paraná uma crise que só foi superada após a década de 50 com o aumento dos preços do café. Após a década de 60 a cafeicultura passou a estimular a urbanização no Norte do Paraná, contemplando Paranavaí com o desenvolvimento da agricultura inicialmente se destacando o ciclo do café seguido do ciclo do gado.

O desenvolvimento da agropecuária provocou a concentração da propriedade fundiária, fazendo com que na década de 80 a produção de gado bovino de Paranavaí passasse a ser a segunda maior do estado do Paraná.

Em 1990 com a modernização da agricultura houve uma superprodução do café, foi estimulada a cultura da soja e de outras oleaginosas. A cultura da mandioca passa a se destacar e é beneficiada por fábricas locais para a obtenção de farinha. E mais recentemente surgiu a cultura da laranja que é absorvida industrialmente na produção de sucos. Foi criado um Complexo AgroIndustrial - CAl que vem processando industrialmente a mandioca e a laranja na região de Paranavaí. Assim se procedeu a evolução histórica dessa área de estudo. 


\section{PROCEDIMENTOS METODOLÓGICOS}

Para embasar a pesquisa aplicada este trabalho seguiu a linha de Ross (1997), que apresenta as Unidades Ecodinâmicas consideradas ambientes que podem ser facilmente alterados.

O estudo da área urbana, também teve como base Ross (1997) com sua classificação de Unidades Ecodinâmicas Instáveis - ambientes naturais modificados pelo Homem - que foram utilizados para mensurar os processos da arenização em áreas urbanas, cerne desta pesquisa.

Esse pesquisador adaptou tabelas, onde mensurou as áreas quanto ao grau de instabilidade, outro foco deste estudo, e para isso se fez necessário a confecção de Cartas de Declividade; Vegetação; Tipos de Solo para uma análise posterior e futura discussão.

$\mathrm{Na}$ elaboração do embasamento cartográfico optou-se pela utilização do computador e a triagem manual para maior fidelidade do mapeamento; posteriormente analisou-se o grau de instabilidade urbana da área em questão.

Foi utilizada a técnica de Geoprocessamento no tratamento de imagens, criação e integração dos mapas temáticos via SIG, que serviu como fonte de informação para o diagnóstico ambiental.

O uso de uma base cartográfica precisa ser bem atualizado, constituindo condição para um processo de obtenção, organização e espacialização de uma base confiável de informações. O Georreferenciamento dos dados e informações geradas neste trabalho possuem uma base cartográfica única e comum a todas as informações, de forma que estas pudessem ser otimizadas por processos de integração, superposição e cruzamento, garantindo um mesmo tratamento em termos de áreas, perímetros ou de outras referências cartográficas.

Objetivando a padronização e interação com as demais bases temáticas, transformou-se a base cartográfica existente em modelo digital, através de técnicas de geoprocessamento, desta forma, a disponibilidade da base de 
informações comuns dispostas na base cartográfica, permitiu a geração das cartas temáticas específicas.

Foi utilizada a carta topográfica do Instituto Brasileiro de Geografia e Estatística (IBGE) de 1:25.000, folhas SF-22-Y-D-I-1 de 1972.

A base cartográfica usada foi aplicada especificamente para a obtenção de sua planimetria, altimetria, rede hídrica, acessos rodoviários, toponímias e localização dos centros urbanos, além de subsidiar estudos temáticos voltados a geomorfologia, geologia, pedologia, infra-estrutura e outros relacionados a aspectos físico-estruturais do terreno. Como fonte de dados e apoio no processo de obtenção de informações relativas aos meios físico e biótico, foram utilizadas imagens obtidas pelo satélite de observação da CBERS-2, cena 160/26 de 02/2005, no modo multiespectral e pancromático $(19,5 \mathrm{~m})$.

O uso dessas imagens de satélites proporcionaram o material básico de análise para o diagnóstico a ser obtido através das caracterizações fisiográficas da paisagem, o que desempenhou um papel fundamental na confecção dos mapas temáticos.

A análise e interpretação das imagens, em termos de utilização como instrumento de levantamento, contaram com o apoio de campo de GPS (Global Position System), objetivando estabelecer pontos de amostragem para checagem dos padrões das classes mapeadas. Foram determinados tipos de culturas, classes de uso de solo; pontos amostrais de geologia e geomorfologia entre outros.

Os dados de localização obtidos por GPS em campo, foram interpolados e integrados via Sistema de Informações Geográficas (SIG) às bases temáticas de interesse, fornecendo maior precisão aos produtos gerados.

Para a introdução das informações no formato digital e seu tratamento, foram utilizados "softwares" de aplicação gráfica como Autocad-Map e SIG como SPRING versão 4.1 e ArcView versão 8.0. 
Para propiciar as melhores condições de interpretação das imagens, procedeu-se o tratamento das mesmas em termos de cores como contraste, brilho e equalização de bandas.

Das técnicas de PDI relacionadas ao comportamento espectral dos alvos (vegetação, solos, etc.), foram abordadas a combinação de bandas espectrais, composição colorida falsa-cor ou RGB (Red, Green \& Blue) e Classificação Supervisionada de imagens, levando em consideração a facilidade na aplicação e os bons resultados obtidos por estas técnicas na literatura nacional e internacional. As técnicas de composição colorida falsa-cor ou RGB, permitem o realce da informação contida na imagem de satélite, a partir da adição das cores RGB a 3 bandas selecionadas da imagem, que, posteriormente integradas, formam uma composição colorida (MOREIRA, 2001).

As combinações coloridas das bandas 3/2/1 forneceram maior informação neste estudo, pelo fato de ser uma das mais utilizadas na pesquisa ambiental, permitindo a separação de áreas de uso/ocupação, áreas urbanas das rurais e cursos d'água, possibilitando a observação da vegetação e culturas em diferentes tons de verde-amarelo, áreas urbanas, rurais e solos expostos em tons roxos e cursos d'água em azul escuro.

O próximo passo, tendo como base as imagens processadas, foi a determinação dos padrões que caracterizam tipos diferentes de uso/ocupação do solo da região, com intuito de confeccionar os mapas temáticos. Para isso o método de Classificação Supervisionada, permitiu obter padrões ou classes na imagem, a partir de tratamento estatístico do comportamento espectral das amostras selecionadas (MOREIRA, 2001). Foram adotadas classes que caracterizam os objetos de interesse do estudo, como por exemplo: vegetação arbórea, cultura anual e perene, solo exposto ou preparado para plantio, áreas urbanizadas e corpos d'água.

O método de classificação aplicado utilizou como princípio a análise de grupamento "cluster analysis", calculando a correlação espectral entre amostras de áreas conhecidas e desconhecidas, considerando para isso a distância mínima "Distância Euclidiana" entre elas. Vários padrões de paisagem na imagem não 
puderam ser facilmente reconhecidos devido à resolução da mesma $(19,5 \mathrm{~m})$, portanto foi necessária a verificação in loco para sanar essas dúvidas. Em seguida, os mapas de uso/ocupação foram integrados a outros (rede hidrográfica, malha viária, cartas topográficas do IBGE), previamente obtidos em formato digital via SIG, e por fim foi confeccionado o mapa temático de uso/ocupação da área de estudo.

Neste contexto, o geoprocessamento também foi utilizado, na confecção das cartas temáticas de Declividade do terreno e Modelo Numérico do Terreno (MNT).

A metodologia adotada para a confecção da carta de declividade foi baseada nas técnicas de SIG. A partir de uma planta planialtimétrica, elaborou-se a base cartográfica digital das curvas de nível que serviu como referência para a geração do MNT, e após a sua respectiva classificação, foi confeccionada a carta de classes de declividade do terreno.

Para a classificação das declividades foram utilizados parâmetros da Resolução 031, de 24 de agosto de 1998 (SEMA/IAP), que define os critérios para a classificação e descrição dos declives.

Utilizando-se do programa de computador ArcGis, confeccionou-se a Carta de Orientação de Vertentes elaborada a partir da proposta de De Biase (1977), devido a necessidade de se verificar o direcionamento das baixas vertentes e fundos de vales para a confecção da Carta de Direção e Velocidade dos Ventos de Superfície de Paranavaí.

A partir da sua confecção, evidenciou-se que há o predomínio da disposição urbana no sentido leste - oeste de suas vertentes, com vertentes longas.

A área urbana de Paranavaí apresenta-se com declividades mais acentuadas na porção norte, área de maior espaço para a expansão urbana.

A Carta foi elaborada para análise do direcionamento das vertentes, utilizando o programa de computador - ArcGis -, pois ela influencia no direcionamento dos ventos de Nordeste - Sudoeste - Oeste - Sudeste, na área. 
Para melhor compreender esses fenômenos e processos erosivos da área urbana optou-se também por utilizar a Carta de Fragilidade Ambiental do Plano-Diretor do Município de Paranavaí e a partir dela identificar as áreas onde ocorriam erosão e voçorocamento, que constituem os estágios iniciais da arenização.

Para monitorar as áreas de risco foram confeccionadas varas de medição com o objetivo de avaliar movimentação dos solos, que é uma das conseqüências da arenização / erosão, presentes na área urbana.

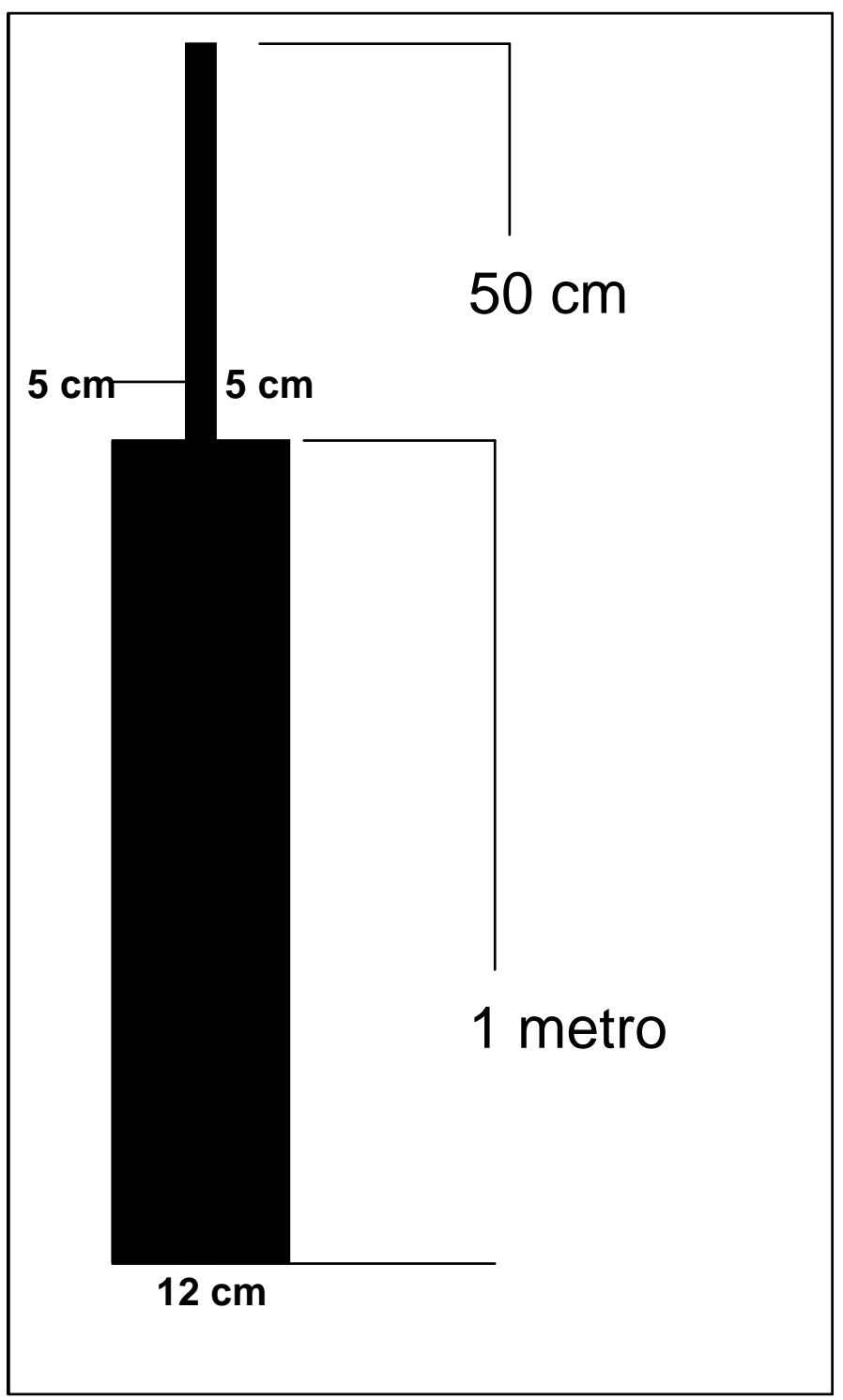

Figura 12. Vara de Medição. Autor: STIPP, M. E. F., 2006. 
As varas foram confeccionadas de metalon com banho ionizado para resistir à ação das intempéries, com $1,50 \mathrm{~cm}$ de altura e duas pás de $5 \mathrm{~cm}$ de cada lado.

A técnica empregada para a instalação e o registro dos dados foi criação deste autor, por não ter encontrado no mercado equipamento disponível que Ihe permitisse realizar a amostragem com a precisão de que necessitava. Consistiu nas seguintes etapas:

a) escavação de uma fossa de 1 metro de profundidade por $15 \mathrm{~cm}$ de largura, a montante da área de voçorocamento e/ou ravinamento;

b) introdução da vara de medição com as pás de contenção de sedimentos voltadas para a parte superior da vertente;

c) Sinalização conveniente para identificação do instrumento de medição, com a instalação de uma fita colorida de aproximadamente $15 \mathrm{~cm}$;

d) reescavação cuidadosa do local, após transcorrido o tempo da pesquisa,isto é, 1 ano após a sua instalação, para medir o deslocamento subsuperficial do terreno, que ficou registrado na pá de contenção, que se dobra devido a força interna durante a movimentação do solo. 


\section{CARACTERIZAÇÃO FÍSICA DA ÁREA EM ESTUDO}

\subsection{O CLIMA}

Para se conhecer o clima de uma determinada região, a partir da sua dinâmica, é preciso que se conheça o mecanismo dos sistemas atmosféricos atuantes na mesma. Sorre apud Conti (2003), dentro desta perspectiva, conceituou o clima como sendo:

sucessão habitual dos tipos de tempo em um determinado lugar define o respectivo modelo do clima. (...)

e a Organização Meteorológica Mundial como sendo:

um conjunto flutuante de condições atmosféricas caracterizadas pelos estados de evolução do tempo no curso de um período suficientemente longo, em um domínio espacial determinado.

Este trabalho procurou analisar a evolução pluviométrica nos anos de estudo (2003 e 2004) fazendo comparação entre uma estação seca e outra chuvosa na área urbana de Paranavaí, demonstrando quais são os principais fatores que contribuem para o surgimento dos impactos ambientais (arenização). Enquanto fenômeno na área em estudo o processo da arenização vêm aumentando em ocorrência da ação do Homem e do tempo climatológico.

O objetivo principal desta pesquisa se prendeu na análise das médias pluviométricas registradas na área urbana de Paranavaí, bem como nos principais impactos urbanos causados pela lixiviação das áreas reconhecidas com a desintegração do solo e o aparecimento de areais e voçorocas.

Por ser um fenômeno especifico a pluviosidade pode ser analisada nas médias mensais no período de 1 ano de pesquisa. 


\subsubsection{O Clima na escala regional}

Por posicionamento geográfico, a região apresenta o clima tropical úmido, com verões quentes e chuvosos e invernos mais secos. A temperatura média anual fica em torno de $22^{\circ} \mathrm{C}$ enquanto a precipitação aumenta do norte-noroeste para o sul, em torno de $1.450 \mathrm{~mm}$.

O clima do noroeste paranaense se caracteriza pelo regime climático mesotérmico superúmido sem estações secas, tipo temperado, caracterizado em toda a região sul do Brasil (IBGE, 1977). A massa Tropical Atlântica que avança para a área vinda do Oceano Atlântico de direção nordeste, promove chuvas de caráter estival.

O regime pluviométrico fica então caracterizado como sendo, no verão (novembro a janeiro) os maiores índices pluviométricos, onde foram registrados a média anual entre 1.250 a $1.500 \mathrm{~mm}$.

A temperatura nos verões chegam ao seu ápice aos $40^{\circ} \mathrm{C}$, sendo janeiro o mês mais quente.

$\mathrm{Na}$ porção do extremo oeste, observam-se as características de subtropicalidade, pois a região está localizada ao sul do trópico de Capricórnio, o que caracteriza a ausência de período seco anual, com chuvas regularmente distribuídas, com temperaturas elevadas no verão. Essa área pode ser considerada como sendo uma área de transição entre o clima tropical e subtropical.

Nimer (1990), classifica o clima em três subunidades distintas: Clima Subquente Superúmido com Subseca - localizado na parte das calhas dos rios Paraná e Piquiri; Clima Subquente Superúmido sem Seca - nas partes mais elevadas da região a ao longo do rio Iguaçu, nas proximidades do rio Paraná; entre um tipo e outro observa-se a zona de transição que é denominada como Mesotérmico Brando, clima das áreas mais elevadas do terreno.

A caracterização desses climas podem ser feitas a partir da sua temperatura e precipitação.O clima Sub-quente, apresenta temperaturas elevadas no verão, com médias entre 24 e 26 graus e no mês mais frio, julho, entre 18 e 15 
graus, embora a área possa ser invadida por massas polares com temperaturas inferiores a zero grau.

A pluviometria da área também varia de acordo com a evapotranspiração e a incidência das massas vindas do Oceano e dos Pólos, com meses mais úmidos e meses mais secos, em torno de $1.450 \mathrm{~mm}$ e $1.900 \mathrm{~mm}$. Podese dizer que nessa área o tipo climático tem o caráter muito mais de continentalidade.

Em observação no Estado, muitos pesquisadores como Nimer (1990), Maack (2002) detectaram um progressivo resfriamento e aumento da precipitação no sentido norte e sul.

O clima Mesotérmico por ser um clima de transição, corresponde às áreas mais elevadas do norte da região, onde se encontram as nascentes de alguns rios e os médios cursos de outros. Tem como característica um inverno mais proeminente com temperaturas entre 15 a 10 graus e geadas noturnas freqüentes. $O$ verão é igualmente quente, com precipitações que variam ente $1.600 \mathrm{~mm}$ a $1.750 \mathrm{~mm}$ anuais, sem ter um período seco.

\subsubsection{Clima na escala local}

Paranavaí possui segundo Koppen o clima do tipo Cfa (h), Subtropical Úmido Mesotérmico, de verões quentes, zona tropical marginal, precipitação regular todos os meses, não existe estação seca e verões quentes, em ritmo de alguns anos de clima seco no inverno e periodicamente Cwa, clima chuvoso temperado (mesotérmico úmido), com inverno seco, sendo o mês mais quente acima de $22^{\circ} \mathrm{C}$ e raras as geadas noturnas.

Temperaturas médias do mês mais frio ficam entre 17 e $18^{\circ} \mathrm{C}$ e a média do mês mais quente entre 24 e $25^{\circ} \mathrm{C}$.

As temperaturas máximas no verão tem alcançado nos últimos anos entre 30 e $35^{\circ} \mathrm{C}$, como pode-se verificar na Tabela 01. 
Devido ao exagerado desmatamento, que tem provocado profunda modificação das paisagens naturais do município, o clima vem sofrendo enormes variações nestes últimos anos, causando uma acentuada perturbação do limite normal entre as zonas climáticas, com grandes alterações do coeficiente de variação das precipitações. Observa-se que a distribuição das precipitações apresenta uma maior intensidade nos meses quentes (dezembro, janeiro e fevereiro).

O trimestre mais chuvoso ocorre em dezembro, janeiro e fevereiro com precipitação entre 180 a $300 \mathrm{~mm}$. 
Tabela 1. Resumos Anuais da Temperatura Mínima na Cidade de Paranavaí - PR.

\begin{tabular}{|c|c|c|c|c|c|c|c|c|c|c|c|c|c|}
\hline \multicolumn{14}{|c|}{ RESUMOS ANUAIS - TEMPERATURA MINIMA - Cidade de Paranavaí - Paraná } \\
\hline ANO & JAN & FEV & MAR & ABR & MAI & JUN & JUL & AGO & SET & OUT & NOV & DEZ & MEDIA \\
\hline \multicolumn{14}{|l|}{1974} \\
\hline 1975 & 9,6 & 1,4 & & 7,2 & 4,1 & & 10,9 & 6,7 & 6,9 & 6,7 & & & \\
\hline 1976 & 20,8 & 19,2 & & 16,5 & 15,7 & 3,3 & 13,0 & 3,8 & 4,6 & 5,3 & & & \\
\hline 1977 & 21,1 & 22,1 & 21,6 & 17,0 & 15,9 & 14,5 & 17,0 & 15,1 & 17,4 & 19,0 & 9,6 & 9,5 & \\
\hline 1978 & 21,1 & 21,0 & 20,8 & 16,5 & 14,0 & 14,0 & 15,7 & 13,1 & 16,0 & 18,9 & & 0,5 & \\
\hline 1979 & 19,3 & 0,9 & 19 & 16,4 & 14,6 & 13,7 & 13,2 & 16,8 & 15,4 & 18,7 & & 0,6 & \\
\hline 1980 & 19,9 & 20,8 & & 19,1 & 16,4 & 13,2 & 14,7 & 5,6 & 13,3 & 18,3 & & 0,9 & \\
\hline 1981 & 21,5 & 1,1 & 9,9 & 17,2 & 7,1 & 3,1 & 11,1 & 15,8 & 16,4 & 7,1 & & 9,5 & \\
\hline 1988 & 20,1 & 0,9 & & 16,8 & 4,6 & 5,2 & 15,3 & 3,5 & 6,4 & 7,9 & & 9,2 & \\
\hline 1983 & 21,5 & 1,1 & & 18,7 & 7,4 & 12,9 & 15,5 & 4,3 & 14,8 & 7,6 & & 0,0 & \\
\hline 1984 & 21,5 & 21,3 & 20,5 & 17,0 & 17,1 & 14,8 & 14,6 & 13,6 & 14,9 & 9,1 & & 9,3 & \\
\hline 1985 & 19,9 & 21,0 & 20,1 & 18,8 & 15,0 & 12,4 & 11,9 & 14,8 & 16,4 & 18,5 & 20,4 & 21,4 & \\
\hline 1986 & 21,4 & 0,9 & 20,0 & 19,3 & 16,5 & 14,4 & 13,1 & 15,9 & 15,3 & 17,2 & & 20,6 & \\
\hline 1987 & 21,3 & 9,5 & 18 & 18,9 & 13,7 & 5 & 16,6 & 3,3 & 15,5 & 3,2 & & 9,9 & \\
\hline 198 & 22,0 & 0,1 & & 19,3 & 5,9 & & 10,9 &, 1 & 17,9 & 7,4 & & 1,3 & \\
\hline 198 & 20,3 & 20,8 & 20,2 & 19,1 & 14,7 & 13,7 & 12,2 & 3,9 & 15,2 & b,0 & & 0,9 & \\
\hline 1990 & 21,2 & 20,6 & 21,4 & 20,3 & 14,4 & 14,0 & 11,2 & 4,6 & 14,0 & 19,4 & & 21,1 & \\
\hline 1991 & 20,9 & 19,9 & 19,9 & 18,2 & 15,5 & 15,4 & 13,0 & 15,6 & 17,3 & 18,5 & & 1,0 & \\
\hline 1992 & 21,3 & 21,6 & & 17,2 & 16,7 & 16,8 & 11,8 & 3,9 & 5,3 & 8,6 & & 0,8 & \\
\hline 1993 & 21,2 & 5 & 20 & 18,5 & 15,0 & 12,9 & 13,0 & t,1 & 16,4 & 9,0 & & 20,5 & \\
\hline 199 & 20,5 & 21,7 & & 18,2 & 17 & 13 & 14,1 & 5,1 & 17,8 &, 6 & & 21,8 & \\
\hline 199 & 21,8 & 1,2 & & 16,1 & 4,9 & 15 & 16,8 & 17,8 & 17,0 & 17,0 & & 20,6 & \\
\hline 1996 & 21,5 & 21,3 & 20,1 & 18,5 & 15,9 & 13,1 & 12,2 & 16,0 & 15,8 & 8,4 & 9,3 & 21,1 & 7,8 \\
\hline 1997 & 21,2 & 21,3 & & 16,9 & 15,1 & 13,8 & 15,4 & 15,7 & 18,6 & 18,8 & & 1,3 & \\
\hline 1998 & 22,2 & 22,0 & 20,8 & 18,3 & 14,8 & 13,0 & 14,9 & 15,9 & 16,4 & 17,9 & & 20,3 & \\
\hline 1999 & 21,0 & 21,5 & & 17,3 & 14,3 & 13,4 & 14,5 & 14,8 & 17,5 & 17,2 & & 20,6 & \\
\hline 2000 & 21,5 & 20,5 & & 18,0 & 14,1 & 15 , & 10,3 & 5,9 & 16,2 & 19,8 & & 20,4 & \\
\hline 2001 & 21,6 & 21,6 & & 19,6 & 14,4 & 13 & 14,8 & 16,9 & 17,0 & 18,7 & & 19,3 & \\
\hline 2002 & 20,1 & 19, & & 20,8 & 16,7 & 16 & 14,0 & 17,4 & 15,7 & 20,6 & & 21,5 & \\
\hline 2003 & 21,5 & 21,6 & 20 , & 18,4 & 14,0 & 16,7 & 15,2 & 11,9 & 15,9 & 17,3 & & 19,9 & 7,6 \\
\hline 2004 & 20,0 & 19,6 & & 19,9 & 13,2 & 13,2 & 13,8 & 14,7 & 19,0 & 17,1 & & 20,1 & 7,4 \\
\hline 2005 & 21,5 & 20,8 & 20,6 & 20,1 & 16,7 & 17,1 & 13,3 & 16,6 & 14,1 & 19,2 & 19,0 & 19,8 & 18,2 \\
\hline 2006 & & & & & & & & & & & & & \\
\hline & 21,0 & 20,9 & 20, & 18,2 & 15,3 & & 13,7 & 15,2 & 16,1 & 18,2 & & 20,4 & 17 \\
\hline & 22,2 & 22,1 & 22 , & 20,8 & 17,4 & 17,1 & 17,0 & 17,8 & 19,0 & 20,6 & 21,4 & 21,8 & \\
\hline MIN & 19,3 & 19,2 & 18,9 & 16,1 & 13,2 & 12,4 & 10,3 & 11,9 & 13,3 & 15,3 & 17,5 & 19,1 & \\
\hline Ur & 0,7 & 0,8 & 0,8 & 1,3 & 1,2 & 1,3 & 1,8 & 1,4 & 1,3 & 1,1 & 0,8 & 0,7 & \\
\hline
\end{tabular}


Tabela 2. Resumos Anuais da Temperatura Máxima na Cidade de Paranavaí - PR.

\begin{tabular}{|c|c|c|c|c|c|c|c|c|c|c|c|c|c|}
\hline \multicolumn{14}{|c|}{ RESUMOS ANUAIS - TEMPERATURA MAXIMA - Cidade de Paranavaí - Paraná } \\
\hline ANO & JAN & FEV & MAR & ABR & MAI & JUN & JUL & AGO & SET & OUT & NOV & DEZ & MÉDIA \\
\hline \multicolumn{14}{|l|}{1974} \\
\hline 1975 & 31,2 & 30,9 & 30,7 & 27,9 & 25,1 & 24,4 & 23,7 & 29,1 & 28,1 & 27,5 & 28,6 & 29,6 & 28,1 \\
\hline 1976 & 31,1 & 29,7 & 30,2 & 27,2 & 24,4 & 22,5 & 23,8 & 24,6 & 23,2 & 27,8 & 29,4 & 30,0 & 27,0 \\
\hline 1977 & 30,0 & 32,9 & 32,1 & 28,1 & 26,9 & 24,8 & 28,2 & 27,4 & 27,9 & 30,5 & 29,5 & 29,7 & 29,0 \\
\hline 1978 & 32,1 & 33,9 & 31,9 & 30,3 & 26,2 & 25,3 & 26,5 & 25,0 & 26,2 & 30,7 & 30,5 & 31,6 & 29,2 \\
\hline 1979 & 31,0 & 32,0 & 31,8 & 28,2 & 25,1 & 25,7 & 23,6 & 28,3 & 25,5 & 29,6 & 29,1 & 29,5 & 28,3 \\
\hline 1980 & 31,0 & 30,2 & 32,1 & 28,7 & 26,5 & 24,0 & 25,3 & 25,9 & 23,6 & 29,6 & 30,0 & 31,1 & 28,2 \\
\hline 1981 & 31,1 & 31,7 & 31,1 & 28,6 & 28,3 & 23,1 & 23,3 & 27,8 & 29,7 & 27,4 & 30,9 & 29,2 & 28,5 \\
\hline 1982 & 31,3 & 31,2 & 30,1 & 28,6 & 25,9 & 23,8 & 25,4 & 26,1 & 28,3 & 29,0 & 30,4 & 28,7 & 28,2 \\
\hline 1983 & 31,7 & 31,3 & 29,7 & 28,5 & 25,7 & 20,4 & 25,5 & 27,4 & 23,5 & 27,7 & 29,9 & 30,9 & 27,7 \\
\hline 1984 & 32,5 & 33,9 & 31,7 & 27,9 & 27,7 & 27,1 & 27,6 & 25,4 & 27,7 & 32,5 & 30,5 & 29,8 & 29,5 \\
\hline 1985 & 31,7 & 32,1 & 30,2 & 29,3 & 26,6 & 23,9 & 24,1 & 27,7 & 28,8 & 31,9 & 33,0 & 34,3 & 29,5 \\
\hline 1986 & 32,9 & 30,7 & 30,6 & 30,3 & 26,2 & 26,2 & 24,7 & 25,9 & 26,7 & 29,7 & 32,5 & 31,0 & 29,0 \\
\hline 1987 & 31,9 & 29,7 & 31,6 & 29,8 & 22,7 & 23,1 & 26,7 & 25,1 & 25,8 & 28,3 & 30,7 & 30,3 & \\
\hline 1988 & 32,4 & 29,1 & 31,0 & 28,8 & 24,0 & 23,5 & 23,2 & 29,1 & 30,1 & 29,2 & 30,2 & 32,4 & \\
\hline 1989 & 28,6 & 29,6 & 29,8 & 28,8 & 25,2 & 23,4 & 23,8 & 24,5 & 25,0 & 28,1 & 29,4 & 30,2 & 27,2 \\
\hline 1990 & 30,0 & 31,6 & 31,9 & 29,7 & 23,8 & 23,2 & 20,5 & 24,5 & 24,7 & 30,1 & 31,2 & 31,5 & 27,7 \\
\hline 1991 & 31,2 & 30,8 & 29,0 & 28,8 & 25,9 & 24,9 & 24,8 & 27,6 & 28,9 & 29,1 & 31,3 & 30,4 & 28,6 \\
\hline 1992 & 32,8 & 31,6 & 28,8 & 26,7 & 24,4 & 25,5 & 22,3 & 24,3 & 24,4 & 28,3 & 30,1 & 31,5 & 27,6 \\
\hline 1993 & 31,7 & 28,2 & 30,6 & 29,2 & 25,4 & 23,0 & 23,1 & 26,0 & 26,4 & 30,0 & 32,1 & 30,5 & 28,0 \\
\hline 1994 & 30,2 & 31,7 & 29,4 & 28,3 & 25,9 & 23,8 & 25,2 & 28,1 & 30,5 & 30,5 & 30,5 & 32,0 & 28,8 \\
\hline 1995 & 30,9 & 30,1 & 30,3 & 27,2 & 25,2 & 25,8 & 26,8 & 30,4 & 28,3 & 27,1 & 30,6 & 30,6 & 28,6 \\
\hline 1996 & 30,6 & 30,3 & 29,5 & 28,7 & 25,5 & 23,0 & 24,3 & 28,4 & 26,7 & 28,5 & 29,7 & 30,5 & 28,0 \\
\hline 1997 & 29,6 & 30,5 & 29,6 & 28,5 & 26,1 & 21,4 & 25,8 & 27,0 & 29,2 & 29,0 & 28,9 & 30,8 & 28,0 \\
\hline 1998 & 32,6 & 30,5 & 30,3 & 26,8 & 24,3 & 23,4 & 25,7 & 25,4 & 24,9 & 28,3 & 30,7 & 30,6 & 27,8 \\
\hline 1999 & 30,6 & 31,2 & 31,1 & 28,4 & 25,0 & 23,1 & 25,2 & 28,1 & 29,9 & 29,6 & 30,0 & 32,0 & 28,7 \\
\hline 2000 & 32,4 & 30,1 & 29,6 & 29,9 & 25,1 & 26,0 & 22,0 & 26,4 & 26,2 & 31,5 & 30,4 & 30,5 & 28,3 \\
\hline 2001 & 31,5 & 30,8 & 31,1 & 30,3 & 24,4 & 22,9 & 25,8 & 28,3 & 27,8 & 30,1 & 30,6 & 29,7 & 28,6 \\
\hline 2002 & 31,1 & 30,4 & 33,2 & 32,9 & 25,8 & 27,5 & 23,7 & 28,4 & 27,1 & 32,2 & 30,6 & 32,3 & 29,6 \\
\hline 2003 & 30,7 & 31,6 & 31,0 & 28,9 & 25,6 & 27,2 & 26,3 & 24,5 & 28,1 & 30,0 & 30,7 & 30,9 & 28,8 \\
\hline 2004 & 31,4 & 32,0 & 31,2 & 29,3 & 21,4 & 22,9 & 22,5 & 27,8 & 31,0 & 28,2 & 29,2 & 31,2 & 28,2 \\
\hline 2005 & 29,7 & 32,5 & 32,6 & 30,3 & 27,5 & 26,7 & 23,6 & 28,3 & 24,3 & 28,7 & 30,3 & 30,5 & 28,8 \\
\hline \multicolumn{14}{|l|}{2006} \\
\hline MED & 31,2 & 31,1 & 30,8 & 28,9 & 25,4 & 24,2 & 24,6 & 26,9 & 27,0 & 29,4 & 30,4 & 30,8 & 28,4 \\
\hline MAX & 32,9 & 33,9 & 33,2 & 32,9 & 28,3 & 27,5 & 28,2 & 30,4 & 31,0 & 32,5 & 33,0 & 34,3 & \\
\hline MIN & 28,6 & 28,2 & 28,8 & 26,7 & 21,4 & 20,4 & 20,5 & 24,3 & 23,2 & 27,1 & 28,6 & 28,7 & \\
\hline $\mathrm{DP}$ & 1,0 & 1,3 & 1,1 & 1,2 & 1,4 & 1,7 & 1,7 & 1,6 & 2,2 & 1,4 & 1,0 & 1,1 & \\
\hline
\end{tabular}

Fonte: IAPAR, 2006. 


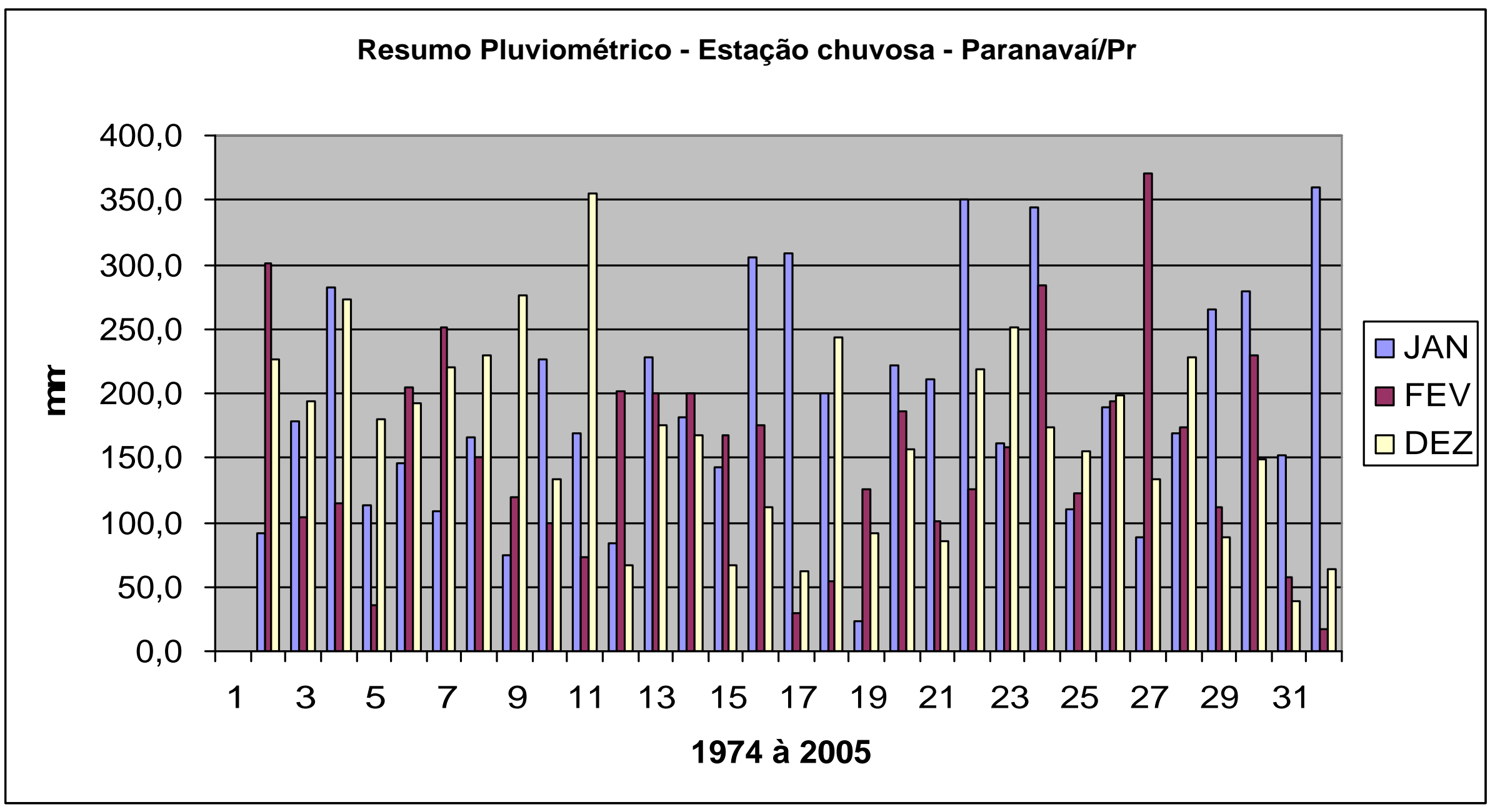

Figura 13. Gráfico de Resumo Pluviométrico na Estação Chuvosa de Paranavaí. Fonte: Instituto Agronômico do Paraná (IAPAR), 2006.

No trimestre menos chuvoso: junho, julho, e agosto, a precipitação se apresenta entre 50 a $150 \mathrm{~mm}$. 


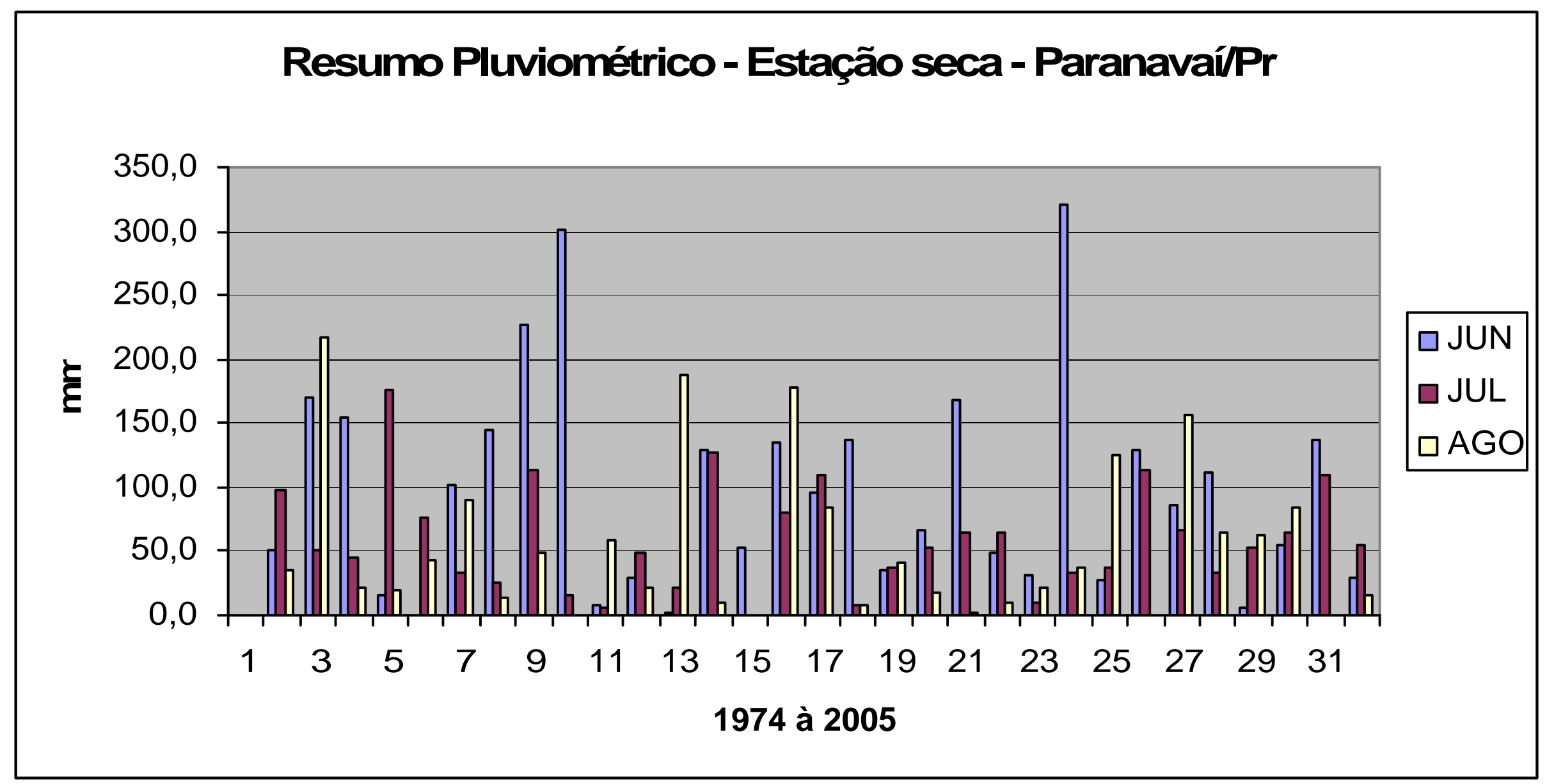

Figura 14. Gráfico de Resumo Pluviométrico na Estação Seca de Paranavaí. Fonte: Instituto Agronômico do Paraná (IAPAR), 2006.

A variação da média anual das precipitações na série 1974 - 2005, ficou entre 1050 (1978) a 2.100 mm (1997), 


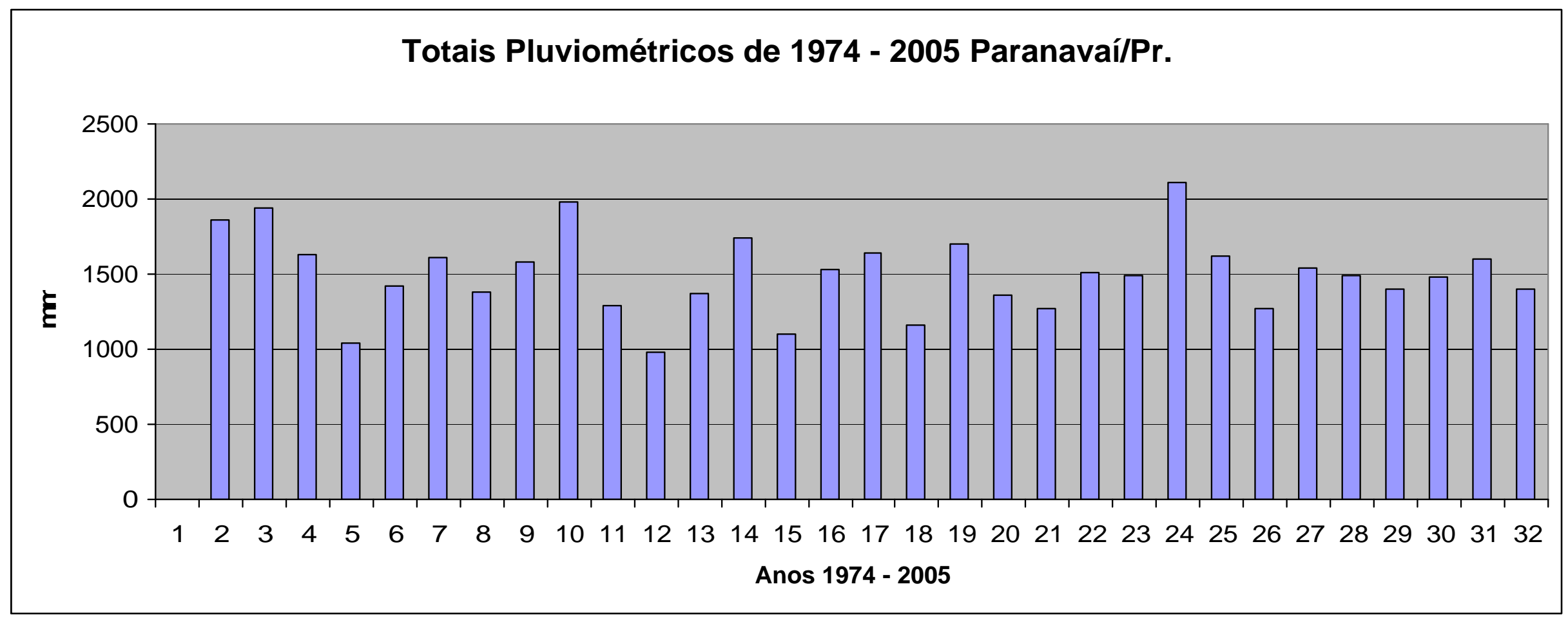

Figura 15. Gráfico de Totais Pluviométricos de 1974-2005 de Paranavaí. Fonte: Instituto Agronômico do Paraná (IAPAR), 2006. 
Tabela 3. Resumos Anuais da Precipitação de Paranavaí.

\begin{tabular}{|c|c|c|c|c|c|c|c|c|c|c|c|c|c|}
\hline \multicolumn{14}{|c|}{ RESUMOS ANUAIS - PRECIPITAÇÃO - Cidade de Paranavaí - Paraná } \\
\hline ANO & JAN & FEV & MAR & $A B R$ & MAI & JUN & JUL & AGO & SET & OUT & NOV & DEZ & SOMA \\
\hline 1974 & & & & & & & & & & & & & 0,0 \\
\hline 1975 & 91,6 & 1,5 & 2,6 & 95,8 & 100,3 & 51,8 & 97,3 & 35,3 & 05,0 & 378,3 & 181,1 & 226,8 & 1857,4 \\
\hline 1976 & 178,7 & 04,2 & 30,8 & 155,9 & 196,2 & 170,4 & 50,0 & 216,8 & 182,2 & 294,8 & 115,1 & 93,1 & 1938,2 \\
\hline 1977 & 282,7 & 114,9 & 54,8 & 67 & 74,2 & 154,5 & 44,0 & 1,2 & 112,8 & 77,7 & 254,8 & 72,6 & 163 \\
\hline 1978 & 112,7 & 35,9 & 3,7 & & 69,5 & 14 & 175,3 & 9 & 43,1 & 89,5 &, 9 & 30,3 & 104 \\
\hline 1979 & 145 & 205,3 & & & 157,5 & & 5,4 & & 198,8 & 32,7 & & 11,9 & \\
\hline 1980 & 108 & 250,8 & 3,2 & & 146,7 & 100,7 & 32,4 & & 212,7 & 50,1 & 2,5 & 20,0 & 1607 \\
\hline 1981 & 165 & 149,7 & 94,4 & 131 & 5,4 & 143,8 & 26,3 & & 16,4 & 275,5 & 129,7 & 230,1 & 1382,3 \\
\hline 1982 & & 119,9 & 88,9 & & 42,7 & & 114,0 & & 40,8 & & & 275,9 & 157 \\
\hline 1983 & 226 & 99,6 & 267,1 & & 217,1 & 300,6 & 15,9 & 0,0 & 240,8 & 119,2 & 71,9 & 34,0 & 1977,3 \\
\hline 1984 & 168,6 & 73,4 & & & 50,1 & & 5,7 & & 164,0 & 35,4 & 37,5 & 55,0 & 1285,6 \\
\hline 1985 & 84 & 201,5 & & & 110, & 29 & & & & & & 3,2 & gr/1 \\
\hline 1986 & & 0,7 & & & 166,4 & & & & & & & 5,8 & \\
\hline 1987 & & 200,5 & & 16 & 256,3 & 128,1 & 126,4 & & 105,6 & 8,2 & & 67,1 & \\
\hline 1988 & 142 & 167,7 & 127,4 & & 133,8 & & 0,0 & & 36,0 & & & 6,3 & \\
\hline 1989 & 306 & 174,8 & & & 34,4 & 134,5 & 79,7 & 178,8 & 194,2 & & & 10,9 & 3,9 \\
\hline 1990 & 308 & 29,0 & 0,0 & 106 & 154,4 & 95 & 109,8 & & 199,0 & 202 & & 1,6 & 16 \\
\hline 1991 & 200 & 54,6 & & & 29, & 136 & 7,4 & & & & & 42,8 & \\
\hline 1992 & & & & & 350 & & & & 260 & & &, 5 & \\
\hline 1993 & 222 & & & & & & & & 132,7 & & & b,8 & \\
\hline 1994 & 211 & 100,4 & & & 100,7 & & 65,3 & & 59,0 & & & 5,1 & \\
\hline 1995 & 350,9 & 125,2 & & & 22,3 & & 63,8 & & 172,0 & 25 & & 9,0 & 151 \\
\hline 1996 & 160,8 & 157,4 & 5,1 & & 99 , & & 10, & & 140,1 & & 136,5 & 50,5 & \\
\hline 1997 & 343 & 3,7 & & & 95, & 319 & 33 & & & & 265,4 & 73,8 & \\
\hline 1998 & $11 C$ & & & 204 & 78, & & 37,0 & 125,3 & 305,2 & $15 s$ & & 55,2 & \\
\hline 1999 & 185 & & & & 85, & 129 & 113 & & & & & 98,9 & \\
\hline 2000 & 87 & & & & 35,0 & & 67,2 & 156,2 & 206,1 & & & 3,2 & 1535 \\
\hline 2001 & & & & & & & & & & & & 228,2 & \\
\hline 2002 & & 111,5 & & & 373,2 & & 53,1 & & 134,9 & & 197,2 & 7,6 & 1403,2 \\
\hline 2003 & 279 & 229,6 & & 126, & 49,6 & & 63,7 & 83,9 & 103,0 & ,2 & 4 & 148,4 & 147 \\
\hline 2004 & $15 ?$ & & & & 304 & 13 & 108 , & & &, 7 & 1 & 38,6 & 159 \\
\hline 2005 & 359,2 & & & & & & & & 260,5 & & & 63,3 & 1399,0 \\
\hline 2006 & & & & & & & & & & & & & \\
\hline MED & & & & & 124,5 & & & & 135,0 & & & 167,8 & 1499,3 \\
\hline MAX & 359 & 370,9 & 267,1 & 251 & 373,2 & 319,9 & 175,3 & 216,8 & 305,2 & 378,3 & 278,0 & 355,0 & 2111,6 \\
\hline MIN & & 16 & & 12 & 5, & & 0 & & 6,4 & 35,4 & 26,8 & 38,6 & 0,0 \\
\hline DP & & & 4, & 50,8 & & & 40,4 & 59, & $0, c$ & $\begin{array}{l}9,0 \\
\end{array}$ & 99,4 & 4,9 & $43 /$, \\
\hline
\end{tabular}

Fonte: IAPAR, 2006 
Para o resultado do Balanço Hídrico de Paranavaí, utilizamos o CAD - capacidade de campo, que é o limite máximo para o armazenamento, decorrente do tipo de solo e das exigências hídricas de cada vegetação =100mm.

\section{Paranavaí / Pr:}

- Latitude e Longitude - 23ำ08' lat / 52ำ 43' long

- Altitude - $480 \mathrm{~m}$;

- Período / Normal - 71 - 96 (26);

- DEF. $\mathrm{mm}-0,6$

- $\mathrm{EXC} \mathrm{mm-422,2}$

- $\mathrm{TMA}-22,0$

- Meses de > Temperatura - Dezembro, Janeiro, Fevereiro.

- Meses de < Temperatura - Maio, Junho, Julho.

- Precipitação Média Anual - 125,7.

- Meses de > Precipitação - Outubro, Dezembro, Janeiro.

- Meses de < Precipitação - Abril, Julho, Agosto.

Tabela 4. Classificação Qualitativa do Balanço Hídrico de Paranavaí - PR.

\begin{tabular}{c|c|c|c}
\hline Balanço Hídrico & $\begin{array}{c}\text { Qualificação do } \\
\text { Balanço Hídrico }\end{array}$ & Símbolo & $\%$ \\
\hline $\begin{array}{c}\text { Sem deficiência hídrica e excedente hídrico } \\
\text { entre } 798,26 \text { até } 1.596,52 \mathrm{~mm} / \mathrm{ano}\end{array}$ & Alto & $\mathrm{BH}^{2}$ & 45 \\
\hline
\end{tabular}


O resultado do balanço hídrico nos anos de estudo em Paranavaí ficou entre 20 a $50 \mathrm{~mm}$. Para chegar a esses números utilizou-se Thornthwaite (1955), o que levou a constatar que a área de estudo não apresenta deficiência hídrica (Tabela 3 e Figura 16).

Tabela 5. Balanço Hídrico da Cidade de Paranavaí.

\begin{tabular}{|c|c|c|}
\hline $\mathbf{P}$ & ETP & ETR \\
\hline $\mathbf{m m}$ & Thornthwaite 1948 & Mm \\
\hline 121,20 & 36,77 & 36,77 \\
\hline 3,60 & 45,51 & 33,76 \\
\hline 27,60 & 50,27 & 36,99 \\
\hline 24,00 & 41,32 & 29,13 \\
\hline 32,40 & 41,37 & 34,53 \\
\hline 1,60 & 32,71 & 6,94 \\
\hline 36,90 & 45,68 & 37,97 \\
\hline 117,60 & 34,12 & 34,12 \\
\hline 0,00 & 35,34 & 26,71 \\
\hline 45,20 & 34,70 & 34,70 \\
\hline 18,60 & 32,40 & 27,60 \\
\hline 57,40 & 26,88 & 26,88 \\
\hline 93,30 & 17,37 & 17,37 \\
\hline 78,10 & 11,48 & 11,48 \\
\hline 132,70 & 11,47 & 11,47 \\
\hline 51,70 & 9,64 & 9,64 \\
\hline 34,80 & 11,87 & 11,87 \\
\hline 50,70 & 17,56 & 17,56 \\
\hline 37,60 & 18,59 & 18,59 \\
\hline 71,00 & 10,90 & 10,90 \\
\hline 0,00 & 9,77 & 9,02 \\
\hline 0,00 & 12,02 & 9,26 \\
\hline 0,00 & 18,75 & 11,20 \\
\hline 0,30 & 26,09 & 10,97 \\
\hline 0,00 & 39,58 & 9,59 \\
\hline 33,80 & 17,28 & 17,28 \\
\hline 4,50 & 38,68 & 16,13 \\
\hline 0,00 & 27,42 & 5,56 \\
\hline 139,20 & 26,65 & 26,65 \\
\hline 84,50 & 33,41 & 33,41 \\
\hline 142,80 & 34,31 & 34,31 \\
\hline 99,20 & 30,05 & 30,05 \\
\hline 17,10 & 40,59 & 36,54 \\
\hline 9,10 & 44,16 & 27,05 \\
\hline 4,50 & 42,70 & 15,15 \\
\hline 25,00 & 44,99 & 28,39 \\
\hline
\end{tabular}




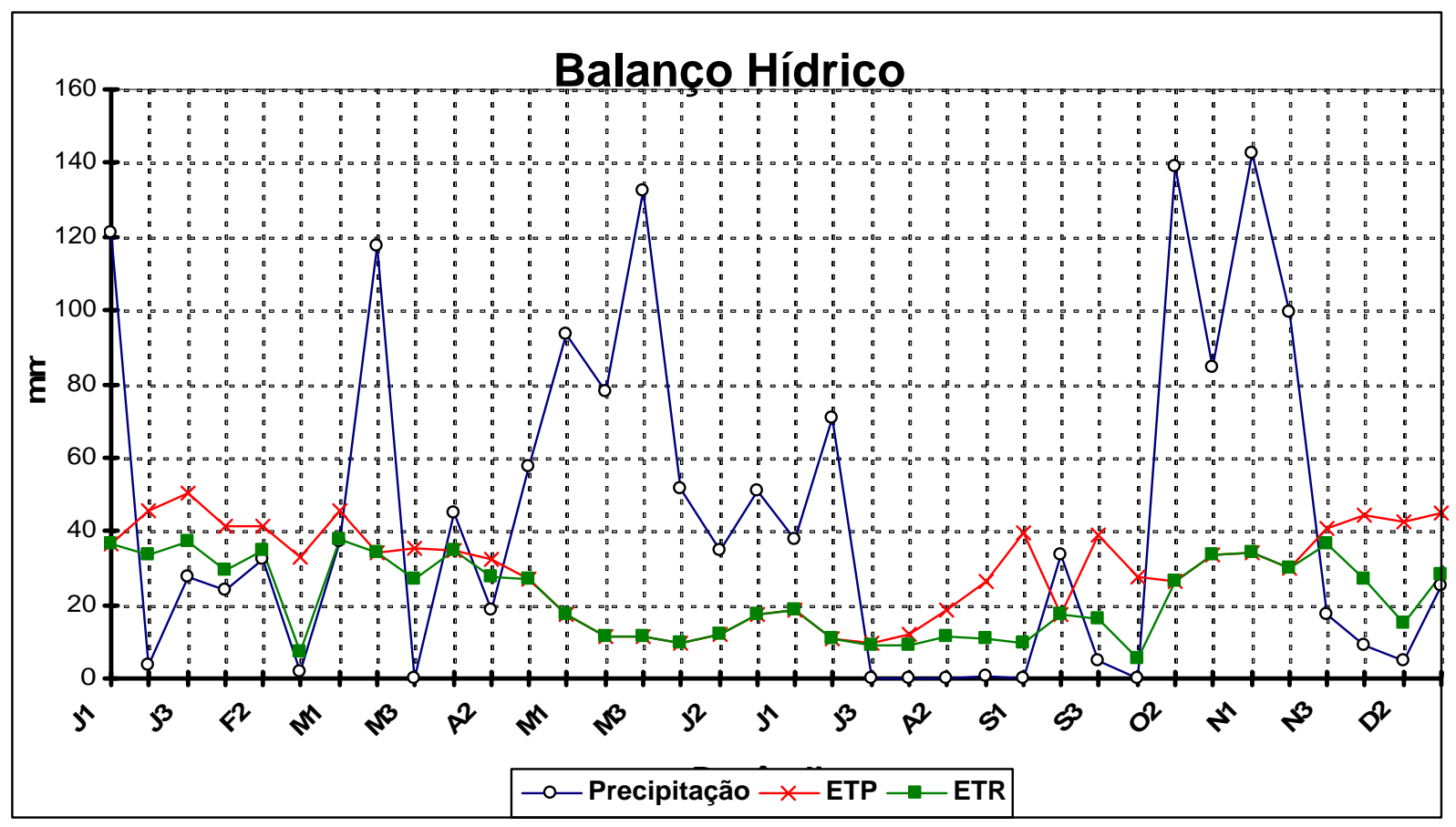

Figura 16. Gráfico do Balanço Hídrico de Paranavaí. Fonte: IAPAR 2006.

A estação de Paranavaí, apresenta um pequeno déficit nos meses de agosto e setembro, onde os valores médios de evapotranspiração potencial superaram ligeiramente os de precipitação pluviométrica.

\subsection{VegetAÇÃo}

\subsubsection{Cobertura vegetal regional}

A área de estudo está inserida na região da Floresta Estacional Semidecidual, cujo conceito ecológico está condicionado pela dupla estacionalidade climática, uma tropical, com épocas de intensas chuvas de verão, seguidas por estiagem acentuada, e outra subtropical, sem período seco, mas com seca fisiológica provocada pelo intenso frio de inverno.

Dentre as quatro formações delimitadas, no país para essa região fitoecológica (aluvial, terras baixas, submontana e montana), somente duas ocorrem 
na área: a Floresta Estacional Semidecidual Aluvial e a Floresta Estacional Semidecidual Submontana (CAMPOS \& SOUZA, 1997).

\subsubsection{Floresta Estacional Semidecidual Aluvial}

Essa floresta se distribuía sobre as planícies aluviais contínuas ou descontínuas e sobre algumas ilhas do Rio Paraná, ladeando a maior parte de seus afluentes da margem direita e os rios Piquiri, Ivaí e Paranapanema na margem esquerda. As planícies aluviais ao longo do rio Paraná, no lado direito, segundo a ELETROSUL (1986), ocupavam uma faixa de três ou mais quilômetros, interpondose entre os sedimentos do rio e a cobertura arenítica da área do contato planície/planalto. Essa área possui uma grande variedade de tipologia de solos que, associada às variações físicas dos terrenos, imprime características peculiares aos agrupamentos florísticos.

Atualmente essa área florestada se encontra reduzida a pequenos e na maioria das vezes, perturbados remanescentes resultantes de atividades antrópicas (CAMPOS \& SOUZA, 1997).

Segundo Emidio (2003), dentre as florestas aluviais pode se distinguir três agrupamentos peculiares:

- Os de solo altamente hidromórficos que são aqueles freqüentemente cobertos pelas águas dos rios, que permitem a formação de espécies arbóreas altamente seletivas, formando florestas muito abertas, constituídas de poucas espécies;

- Os situados em áreas sobre diques aluviais. Originalmente, ao longo do rio Paraná haviam florestas mais desenvolvidas, formadas por vegetação densa e constituídas de árvores emergentes de 25 a 30 metros de altura;

- Áreas mais enxutas e melhor drenadas - Segundo levantamento de ELETROSUL (1986) estas áreas apresentam vegetação mais densa 
tais como: Pateiro - Sloanea guianensis e Fícus spp, formando freqüentemente gregarismos.

\subsubsection{Floresta Estacional Semidecidual Submontana}

Segundo o IBGE (1992) essa floresta ocorre freqüentemente nas encostas interioranas das Serras da Mantiqueira e dos Órgãos, e nos planaltos centrais capeados pelos arenitos Botucatu, Bauru e Caiuá, em altitudes que variam de 100 a 600 metros. O gênero dominante que caracteriza essa floresta no Planalto Paranaense é Aspidosperma, com seu ecótipo A. polyneuron (Peroba-Rosa).

Originalmente a Floresta Estacional Semidecidual Submontana situada na área dos arenitos do Grupo Caiuá, cobria parte do oeste e sobretudo, o extremo noroeste do estado do Paraná. Atualmente essa formação florestal está praticamente extinta na região. Os remanescentes existentes sofreram forte antropização, principalmente pela exploração seletiva de madeiras (peroba e ipê), não se encontrando mais remanescentes florestais originais (CAMPOS \& SOUZA, 1997).

\subsubsection{Formações Não-Florestais}

As áreas de Formações não florestais aparecem na região de formações pioneiras com influência fluvial ocorrendo ao longo das planícies fluviais e ao redor das depressões aluvionares (pântanos, lagunas e lagoas), freqüentemente em terrenos instáveis cobertos de vegetação, em constante sucessão. Caracterizase por ser uma vegetação de primeira ocupação de caráter edáfico ocupando terrenos rejuvenescidos pelas seguidas deposições de solos ribeirinhos aluviais e lacustres. Segundo Campos e Souza (1997), essas formações pertencem ao "complexo vegetacional edáfico de primeira ocupação" (formações pioneiras). O padrão fisionômico dessas formações é tipicamente campestre, de características hidromórficas, apresentando instabilidade, quanto a alguns dos parâmetros 
ecológicos fundamentais (solos e impactos físicos nos períodos de cheias e secas), com a vegetação sempre recuando ou avançando sobre as áreas sujeitas às inundações e aos processos de arrasamento e acumulação de bancos de sedimentos.

Nos trabalhos de campo realizados durante esta pesquisa verificouse que nos terrenos mais enxutos e sujeitos a inundações periódicas ocorrem grandes áreas dominadas pela vegetação graminóide, utilizadas freqüentemente para a pecuária extensiva. Devido ao forte pisoteio do gado têm ocorrido grandes alterações na vegetação original, propiciando a ocupação por plantas invasoras tais como Bidens pilosa (picão-preto) e Cynodon dactilon (grama-seda). A região como um todo, em diferentes níveis, apresenta uma mistura de espécies mais características de um ou de outro ambiente.

A área de estudo originalmente rica em sua biodiversidade sofreu ao longo dos anos constantes ações antrópicas que provocaram a eliminação da vegetação natural. 


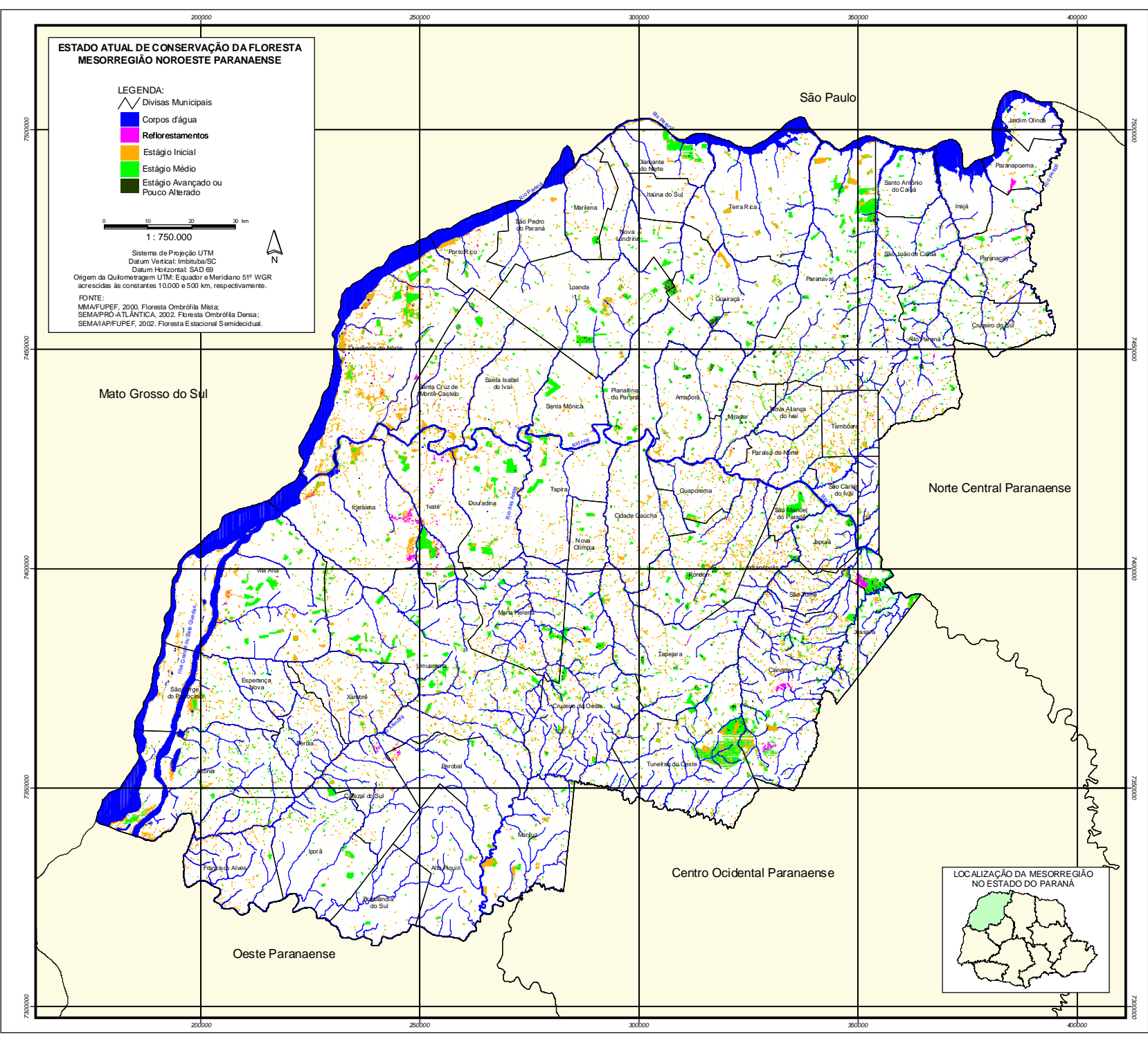

Figura 17. Mapa da Vegetação do Noroeste do Paraná. 
A cobertura florestal nativa ocupa 3,52\% da área da microrregião, que pode ser considerada uma das regiões mais desmatadas do Paraná, com $1,64 \%$ do total de floresta nativa do estado, predomínio da Floresta Estacional Semidecidual (F.E.S.), também conhecida por Floresta do Rio Paraná (SPVS, 1996).

A Floresta Estacional Semidecidual, que cobria boa parte do estado do Paraná, deu lugar aos cultivos agrícolas e às pastagens.Essa situação não é diferente no município de Paranavaí, pois da cobertura original desta região restaram somente alguns fragmentos cercados por matrizes completamente alteradas. As florestas ciliares dos rios desse espaço geográfico também foram bastante descaracterizadas, quando não suprimidas. Assim, a conectividade entre fragmentos florestais é pequena ou inexistente, comprometendo a manutenção da biodiversidade regional.

A Floresta Estacional Semidecidual (Floresta Tropical Subcaducifólia), instalou-se originalmente sobre as formações basálticas que cobriam o Terceiro Planalto paranaense (arenítico). Ecologicamente, esta vegetação estava condicionada pela dupla estacionalidade climática.

Uma estação tropical com intensas chuvas de verão seguida por estiagem acentuada e outra estação subtropical sem período seco, mas com seca fisiológica provocada pelo intenso frio do inverno. A espécie dominante desta floresta e que a caracterizava era a Aspidosperma polyneura (peroba-rosa), sendo também comuns gêneros como Tabebuia sp. (ipê), Copaifera sp. (pau-óleo), e Peltophorum sp. (canafístula).

A riqueza em palmeiras neste tipo de floresta do Norte do Paraná era notável, principalmente a abundância de exemplares de Euterpe edulis, conhecido como palmito Jussara, este caracterizava a mata virgem, constituindo freqüentemente densos agrupamentos. Infelizmente hoje ele figura como uma das principais espécies na lista de espécies raras ou em vias de extinção na região.

Geralmente dominam nas matas ainda existentes três espécies de árvores que dão à mata um cunho especial. Em primeiro lugar aparece a apocinácea, Aspidosperma polyneuron vulgarmente conhecida por peroba. Neste 
gênero distinguem-se diversas espécies de Aspidosperma, peroba amarela (Aspidosperma ramiflorum) e guatambu (Aspidosperma parvifolium).

Em segundo lugar incluem-se as diversas espécies de meliáceas conhecidas vulgarmente por cedrilho (Cedrela odorata), cedro vermelho ou rosa (Cedrela fissilis). As canjaranas (Cabralea canjarana subsp. canjarana).

Diversas espécies de lauráceas, vulgarmente conhecidas por canela, ocupam o terceiro lugar, destacando-se a Nectandra megapotamica. Incluem-se ainda a canela sassafras (Ocotea odorifera), canela amarela (Nectandra lanceolata).

Observa-se acentuada predominância de leguminosas como o monjoleiro (Acacia polyphylla), monjolo (Piptadenia gonoacantha), aleluia (Senna multijulga), a famosa aleluia da Serra do Mar.

Na mata pluvial ao longo dos rios Ivaí, Piquiri e Paraná era freqüente a ocorrência da laranja silvestre (Citrus sinensis), laranjeira comum degenerada, atualmente quase extinta em virtude das devastações. A paisagem se completa com a presença das altas taquaraçus (Bambusa guadua), que caracterizam a zona marginal do rio Paraná e do curso inferior do Ivaí, marginando os extensos pântanos e várzeas.

Os fatores mais importantes para a formação desta tipologia de floresta são: o grande teor de umidade proveniente da distribuição das precipitações por todos os meses do ano, o conseqüente ciclo biológico contínuo e a multiplicidade de espécies que crescem em pequena área.

Essa paisagem primitiva do Noroeste paranaense foi totalmente alterada nos últimos 50 anos. As matas do município de Paranavaí praticamente desapareceram, restando apenas áreas residuais correspondentes a um Bosque Municipal transformado recentemente em Parque Municipal, um Bosque na região do Córrego Xaxim e algumas áreas de Reserva Florestal Legal de propriedades particulares.Áreas essas com potencial interessante para serem transformadas em Reservas Particulares de Patrimônio Natural (RPPN), pois compõem os raros fragmentos florestais do município. 


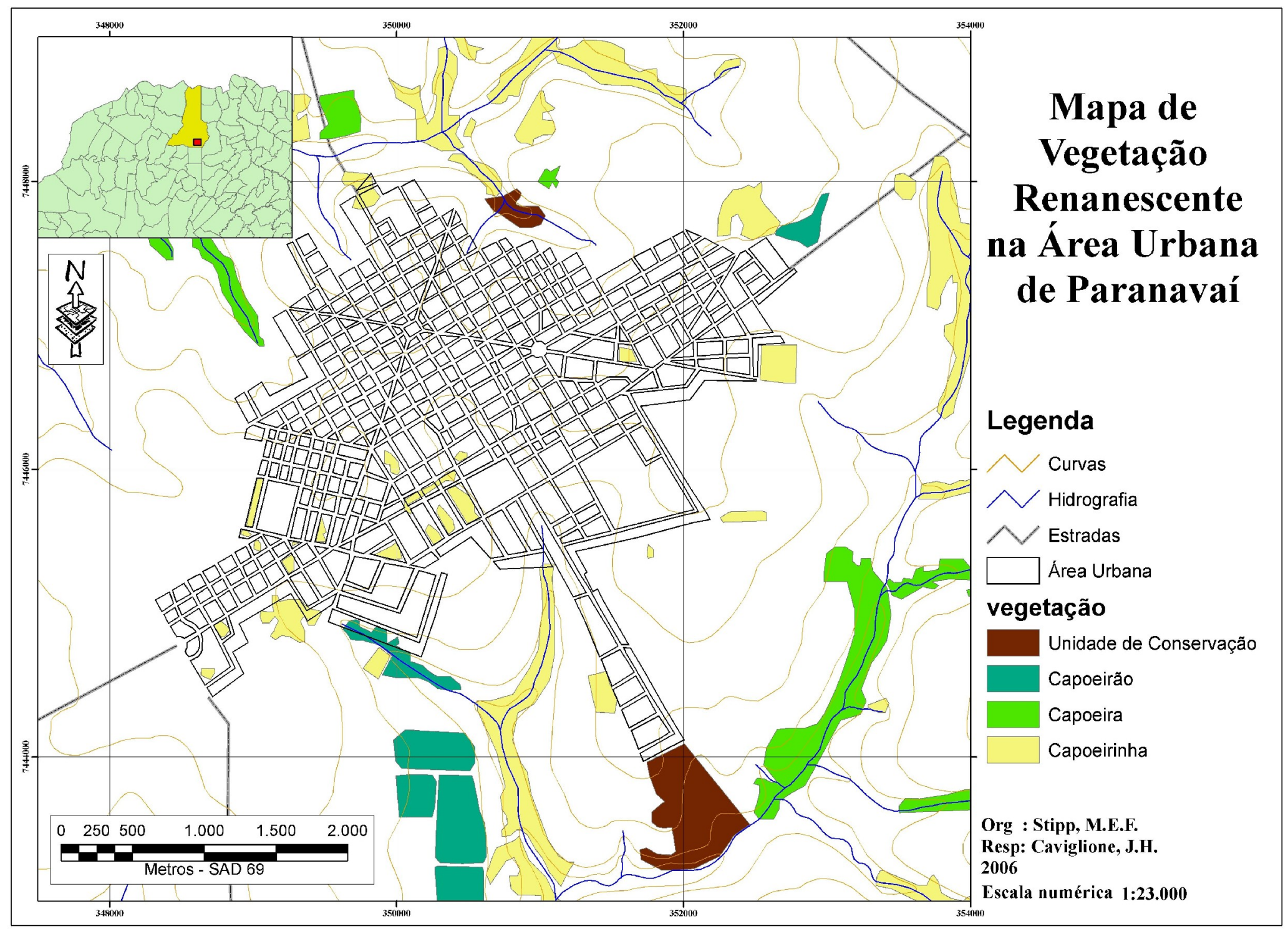

Figura 18. Carta da Vegetação remanescente da área urbana de Paranavaí. 


\subsection{Geologia Regional}

A região Noroeste do Paraná está localizada na região do Terceiro Planalto, Maack (2002). Nessa região ocorreram os derrames vulcânicos no Cretáceo da Formação Serra Geral, pertencente ao Grupo São Bento (Bacia do Paraná) capeados a noroeste pelos arenitos do Grupo Caiuá e Grupo Bauru.

\subsubsection{Grupo Caiuá}

Os arenitos do Grupo Caiuá correspondem à sedimentação de origem eólica, que imperou no interior da Bacia Bauru, no Cretáceo Superior. Esta bacia formou-se sobre a Plataforma Sul-americana, após o rompimento do Mega Continente Gondwana e a separação das Placas Africana e Americana. Os ventos predominantes sopravam para o quadrante sudoeste, construindo grandes dunas e complexos de dunas (draas). Esta área constituiu um imenso deserto arenoso (sand sea) quente e seco, inóspito à vida (FERNANDES, 2002).

Esse Grupo ocorre no Terceiro Planalto Paranaense, compartimento geomorfológico que abrange desde as cuestas basálticas até as margens do rio Paraná. O relevo nessa grande área de arenitos Caiuá se caracteriza pela monotonia de amplas colinas, de extensos e arredondados topos, com encostas de baixa declividade e perfil convexo. Nessa topografia regional destacam-se os morros Três Irmãos (PR) com 639m e do Diabo (SP) com 603m.

O Grupo Caiuá é constituído pelas Formações: Rio Paraná, GoioErê e Santo Anastácio. As unidades Rio Paraná e Goio-Erê são constituídas por arenitos quartzosos e marrons-avermelhados a arroxeados, finos a muito finos, às vezes subarcoseanos, apresentando estratificação cruzada. São diferenciados pelo tipo e geometria das litofácies eólicas presentes, pelo porte dos litossomas e ainda pela área de ocorrência na bacia (FERNANDES, 2002). 
A Formação Rio Paraná caracteriza-se por sucessões de unidades de estratos cruzados de grande porte, enquanto a Formação Goio-Erê apresenta arranjo típico em camadas de espessura média decimétrica, maciças ou com estratificação cruzada de médio a pequeno porte, freqüentemente intercaladas. Está constituída por arenitos de menor maturidade relativa que a unidade anterior, com freqüente cimentação e concrecionamento carbonático.

A Formação Santo Anastácio é constituída por arenitos quartzosos marrom-arroxeados claros, eventualmente subarcoseanos, muito finos a finos, com fração sílica subordinada. Nesta unidade os arenitos apresentam aspectos maciços, às vezes com estratificação plano-paralela ou cruzada de baixa inclinação, mal definidas.

Essas três formações se caracterizam pela cor marrom-avermelhado a arroxeado, mais pálido para a última, característica de red beds (FERNANDES, 2002).

\subsubsection{Formação Rio Paraná}

A Formação Rio Paraná ocorre no noroeste do Paraná e extremo oeste do estado de São Paulo, aflorando no Vale do Rio Paraná até a região de Pereira Barreto (SP). Na margem esquerda do Rio Paraná se evidenciam suas melhores exposições. Suas maiores espessuras no noroeste do Paraná ocorrem em Altônia (277m); em Terra Rica (205m) e no Pontal do Paranapanema (SP), segundo Bigarella \& Mazuchowski (1985).

Nas encostas dos morros Três Irmãos (Terra Rica, PR) e do Diabo (Teodoro Sampaio, SP), as elevações se mantêm devido à silicificação dos arenitos.Essa formação se apresenta de forma contínua se assentando diretamente sobre a Formação Serra Geral (basaltos), da qual é separada pela nãoconformidade, evidenciando contato lateral gradual com a Formação Goio-Erê. Na sua base ocorre estrato de aspecto brechóide, com até $1 \mathrm{~m}$ de espessura, constituído de arenito lamoso maciço, imaturo, com fragmentos centimétricos de basaltos, 
nódulos de esmectita e carbonato, freqüentemente cimentados por carbonatos (FERNANDES, 2002).

Contexto Deposicional: Os arenitos com estratificação cruzada correspondem a depósitos de construções eólicas, de grande porte (draas), complexos de dunas de cristas sinuosas, amalgamadas, da região central de sand sea. A região do Pontal do Paranapanema e extremo noroeste do Paraná, onde ocorrem sets de estratificações cruzadas de maior porte foi provavelmente a área central do antigo Deserto Caiuá (FERNANDES \& COIMBRA, 2000).

\subsubsection{Formação Goio-Erê}

A Formação Goio-Erê ocorre apenas no estado do Paraná, no extremo sudeste da Bacia Bauru. Suas maiores espessuras preservadas giram em torno de 50m. Apresenta contato transicional com a formação Rio Paraná e contatos erosivos (não-conformidade) com os basaltos da Formação Serra Geral.

Contexto Deposicional: Corresponde a depósitos de dunas eólicas de porte moderado de cristas sinuosas e interdunas úmidas ou aquosas, de áreas periféricas de sand sea, sujeitas a oscilações freqüentes do nível freático raso. (Fernandes, 2002).

\subsubsection{Formação Santo Anastácio}

A Formação Santo Anastácio ocorre principalmente nas calhas dos baixos vales dos afluentes do Rio Paraná em São Paulo, Paraná e Minas Gerais. Apresenta espessura máxima preservada de 70 a 100m. No Paraná aparece exposto na região norte-noroeste de Maringá (Colorado, Guaraci e Astorga).

Apresenta passagens graduais e recorrentes para as Formações Rio Paraná e Vale do Rio do Peixe, onde se assenta diretamente sobre basaltos da Formação Serra Geral.Pode se encontrar delgados estratos basais com fragmentos 
de basalto imersos em arenitos imaturos, semelhantes aos da base das Formações Rio Paraná e Goio-Erê. A área de ocorrência da Formação Santo Anastácio contorna a da Formação Rio Paraná, para a qual passa gradualmente.

Contexto Deposicional: Corresponde a depósitos de lençóis de areia (sand sheets), essencialmente secos, acumulados em extensas e monótonas planícies desérticas, marginais dos grandes complexos de dunas do sand sea (Deserto Caiuá). De modo restrito apresentam intercalações de depósitos de enxurradas de chuvas torrenciais esporádicas (wadis), como se observa na região de Mairá, a Litofácies Mairá, depósitos conglomeráticos fluviais e de deflação, com ventifactos.

O Grupo Caiuá, sobretudo suas unidades correspondentes a depósitos mais periféricos do grande deserto de dunas arenosas, passa gradualmente para unidades do Grupo Bauru. No Paraná a única destas unidades aflorantes é a Formação Vale do Rio do Peixe, que ocorre nas partes superiores de colinas no norte do Estado.

Aí foi registrada a única ocorrência de ossos de vertebrados em litofácies de origem aquosa, prováveis depósitos de enxurradas de desertos (wadis) (FERNANDES, 2002).

\subsubsection{Sedimentação Quaternária}

De acordo com Gasparetto \& Souza (2003) ao longo das principais drenagens do Terceiro Planalto Paranaense ocorrem depósitos sedimentares de origem aluvial ou coluvial que podem dar origem a planícies de inundação e a pequenos terraços, identificados por cotas altimétricas diferenciadas. As dimensões e espessuras desses depósitos são dependentes do substrato rochoso, do tamanho do rio, da quantidade e dimensões da carga transportada pelo rio e da geomorfologia local. Esses depósitos são formados por seqüências sedimentares distintas desde sedimentos grosseiros que originam as cascalheiras, camadas de areias, a materiais finos argilosos. 
Justus (1985) apud Gasparetto \& Souza (2003) descrevendo um depósito situado na margem esquerda do Rio Ivaí, próximo à cidade de São João do Ivaí, salienta que sobre o basalto alterado ocorre $70 \mathrm{~cm}$ de material coluvial encoberto por uma camada rudácea de $130 \mathrm{~cm}$ de espessura constituída de bloco de basalto com até $50 \mathrm{~cm}$ de diâmetro, além de seixos e grânulos de quartzo e calcedônia. Sobre a cascalheira desenvolve-se uma cobertura de $170 \mathrm{~cm}$ de material coluvial vermelho de textura areno-argilosa contendo pequenos fragmentos de seixos e grânulos de basalto, quartzo e calcedônia, mais freqüentemente encontrados na base da camada.

Nas drenagens menores aparecem os pequenos depósitos inconsolidados ao longo da calha aluvial do vale do rio, constituídos por uma mistura de seixos, areias, silte e argila de cor variada, geralmente em tons claros. Esses materiais são provenientes na maioria das vezes diretamente do Arenito Caiuá e dos materiais existentes ao longo das vertentes. Quando a drenagem se desenvolve sobre os basaltos, estes também passam a contribuir para a formação desses depósitos. Podem ser encontradas ainda, cascalheiras atuais originadas do retrabalhamento de depósitos mais antigos. 


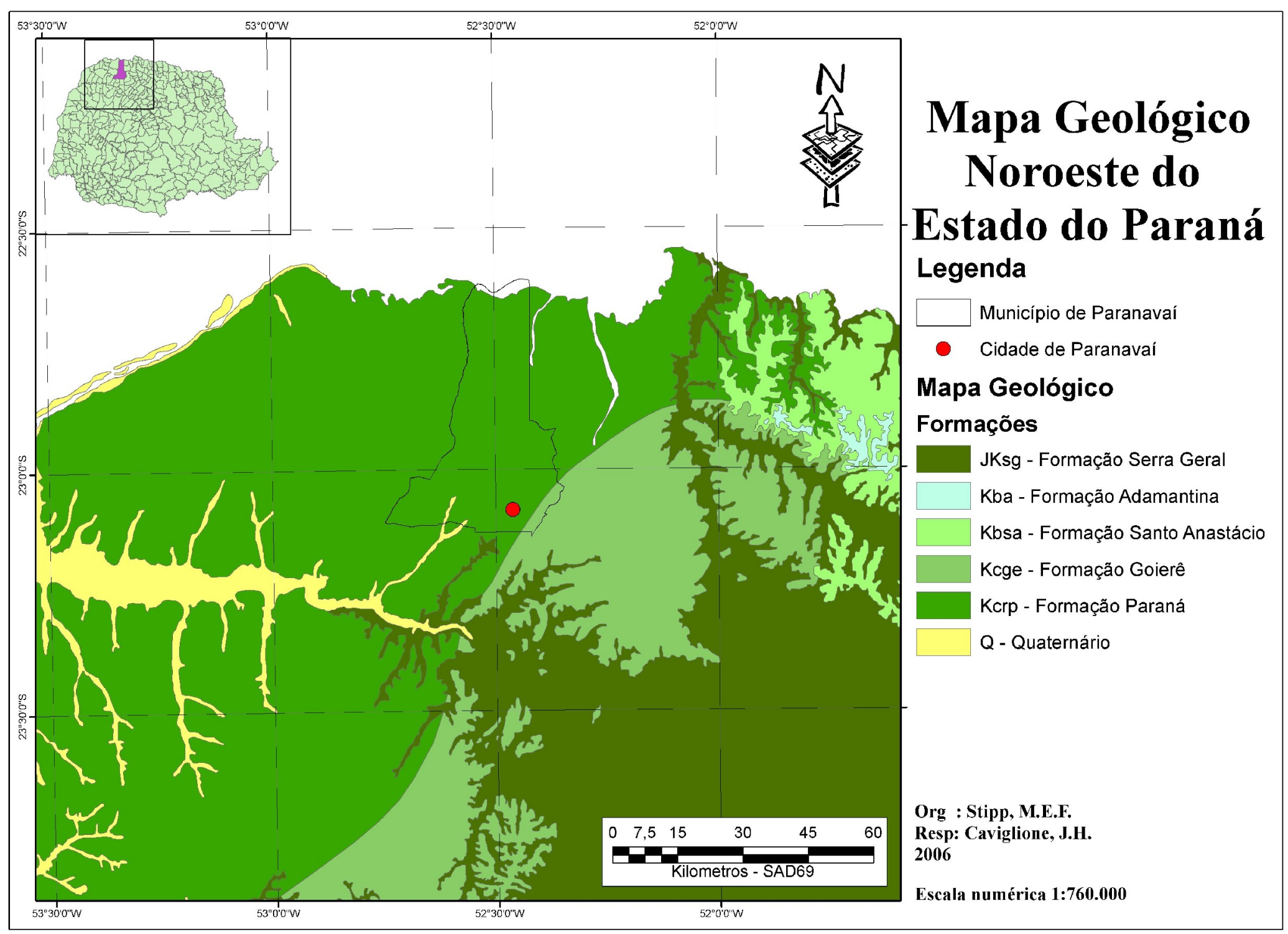

Figura 19. Mapa Geológico da Área de Estudo. 


\subsection{Características Geomorfológicas Regionais}

De acordo com Maack (2002) os vales dos rios Tibagi, Ivaí, Piquiri e Iguaçu serviram de base para distinção de cinco sub-zonas naturais ou sub-planaltos do Terceiro Planalto:

1. Bloco Nordeste: constituído pelo Planalto de Cambará e São Jerônimo da Serra, localizado entre os rios Itararé, Tibagi e Paranapanema;

2. Bloco Norte: constituído pelo Planalto de Apucarana que se estende entre os rios Tibagi, Ivaí e Paraná;

3. Bloco Médio: constituído pelo Planalto de Campo Mourão que se situa entre os rios Piquiri, Iguaçu e Paraná;

4. Bloco sul: constituído pelo Planalto de Guarapuava, situado entre os rios Piquiri e Iguaçu;

5. Bloco sul do rio Iguaçu: abrange a região de Palmas ou vertentes da margem esquerda do rio Iguaçu.

A área desta pesquisa se localiza no Terceiro Planalto na região noroeste do estado do Paraná, portanto no bloco Norte, ou seja, no Sub-Planalto de Apucarana. De acordo com SANTOS et al.1991,a região do Terceiro Planalto Paranaense, principalmente na área de ocorrência do Arenito Caiuá o relevo se apresenta uniforme e monótono. É caracterizado por extensos espigões levemente ondulados com vertentes convexas, longas, de baixa declividade. A maior parte deste relevo apresenta altitudes que variam de 600 metros na região de Maringá e Marialva, a 310 metros nas margens dos Rios Paraná e Paranapanema. Em determinados locais onde a rede de drenagem é mais dissecada ou nas cabeceiras dos principais rios, o relevo exibe colinas em forma de meia laranja, vertentes convexas e desníveis baixos que raramente ultrapassam 50m. 


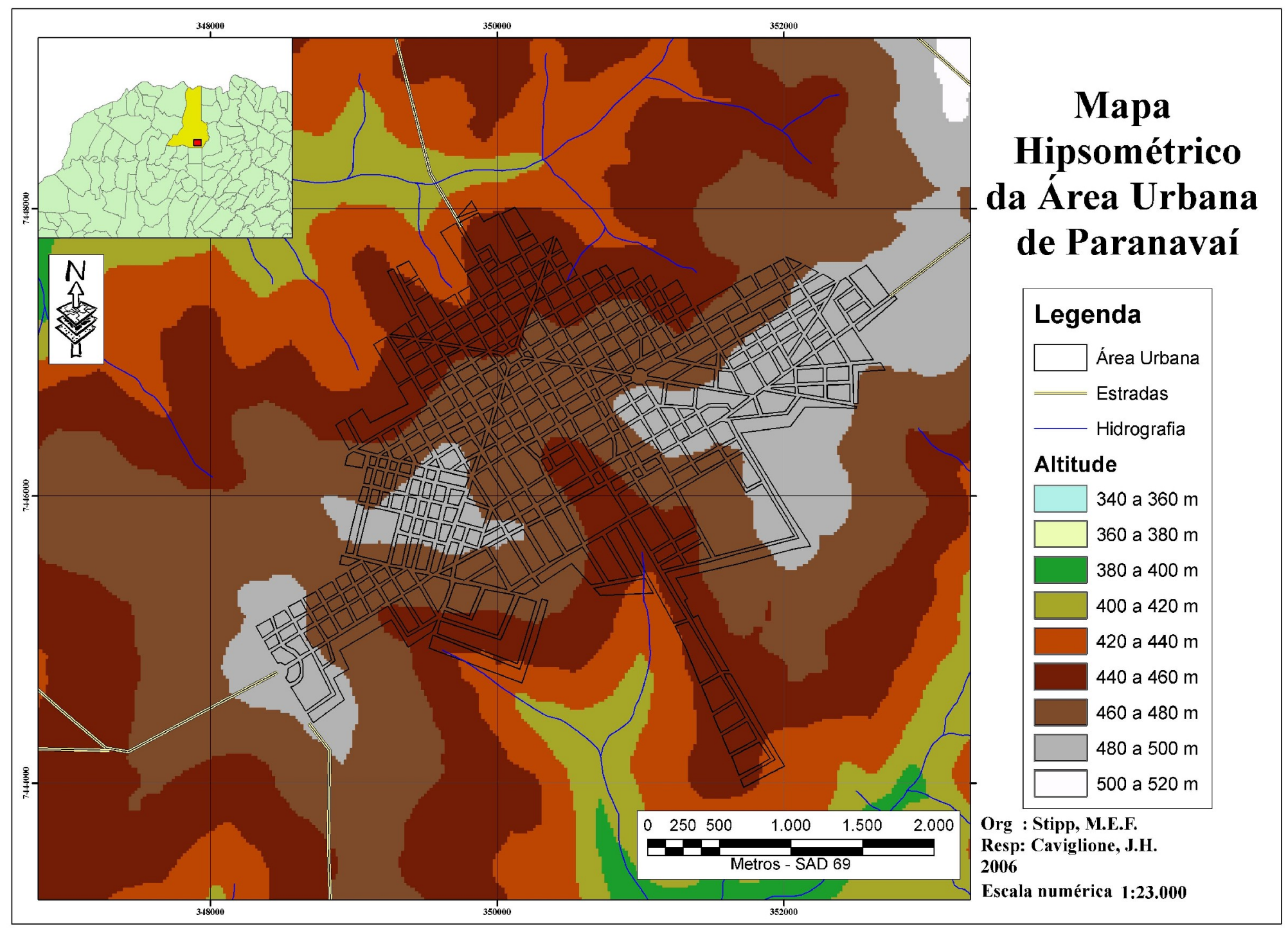

Figura 20. Carta Hipsométrica da Área de Estudo. 
A paisagem monótona do relevo regional somente é interrompida por afloramentos de arenito silicificado e o aparecimento de "morros testemunhos" como os morros Três Irmãos (Terra Rica) e Três Morrinhos (Porto Rico). Da mesma forma ocorrem em determinados locais, colinas que se sobressaem na paisagem devido a presença de carapaças de ferro que atingem até $60 \mathrm{~cm}$ de espessura. Aparecem na paisagem alguns morros isolados originados pela ocorrência de diques de diabásio, comuns nas áreas das rochas eruptivas básicas.(SANTOS, et al.1991)

\section{Domínio dos Arenitos Suprabasálticos}

$\mathrm{Na}$ porção noroeste do planalto a partir do norte de Umuarama, Cianorte e Paranavaí e do oeste de Maringá, Astorga, Centenário do Sul, até os limites do estado predominam os arenitos suprabasálticos do Grupo Caiuá, com uma área de aproximadamente $24.000 \mathrm{~km}^{2}$.

A Formação Rio Paraná devido às suas estruturas e cimentação se torna bastante resistente à erosão, sendo para esta o nível de base, enquanto que o Grupo Goio-Erê devido a sua baixa sedimentação e ausência de estrutura torna-se extremamente suscetível aos processos erosivos tanto na área urbana quanto na rural.

Linearmente a erosão escava o solo formando profundas ravinas com cerca de 10 a $12 \mathrm{~m}$ de profundidade e até centenas de metros de comprimento constituindo as voçorocas que se tornam feições comuns nas cidades de Cianorte, Paranavaí e Nova Esperança acarretando incontáveis prejuízos a esses municípios.

Outra forma erosiva importante e não menos agressiva é a laminar, segundo Buckahan e Brady (1974) "é aquela em que o solo é removido com maior ou menor intensidade em toda a extensão do declive". Esta apesar de pouco perceptível é a responsável pelo paulatino empobrecimento do solo, através do carreamento de nutrientes, matéria orgânica e sedimentos que chegam às drenagens poluindo-as e assoreando-as. 
Geomorfológicamente a região noroeste do Estado do Paraná está bastante dissecada, apresentando um relevo suave com ondulações predominantemente convexas, ocorrendo às vezes colinas alongadas com topos aplainados.

A monotonia do relevo é quebrada pelo aparecimento de morros testemunhos localizados próximos aos Rios Paraná e Paranapanema na região de Porto Primavera. Essas formações apresentam vertentes abruptas com intensa ação coluvial, intenso fraturamento e um nítido alinhamento para noroeste, cuja direção coincide com a dos diques de diabásio da Formação Serra Geral. 


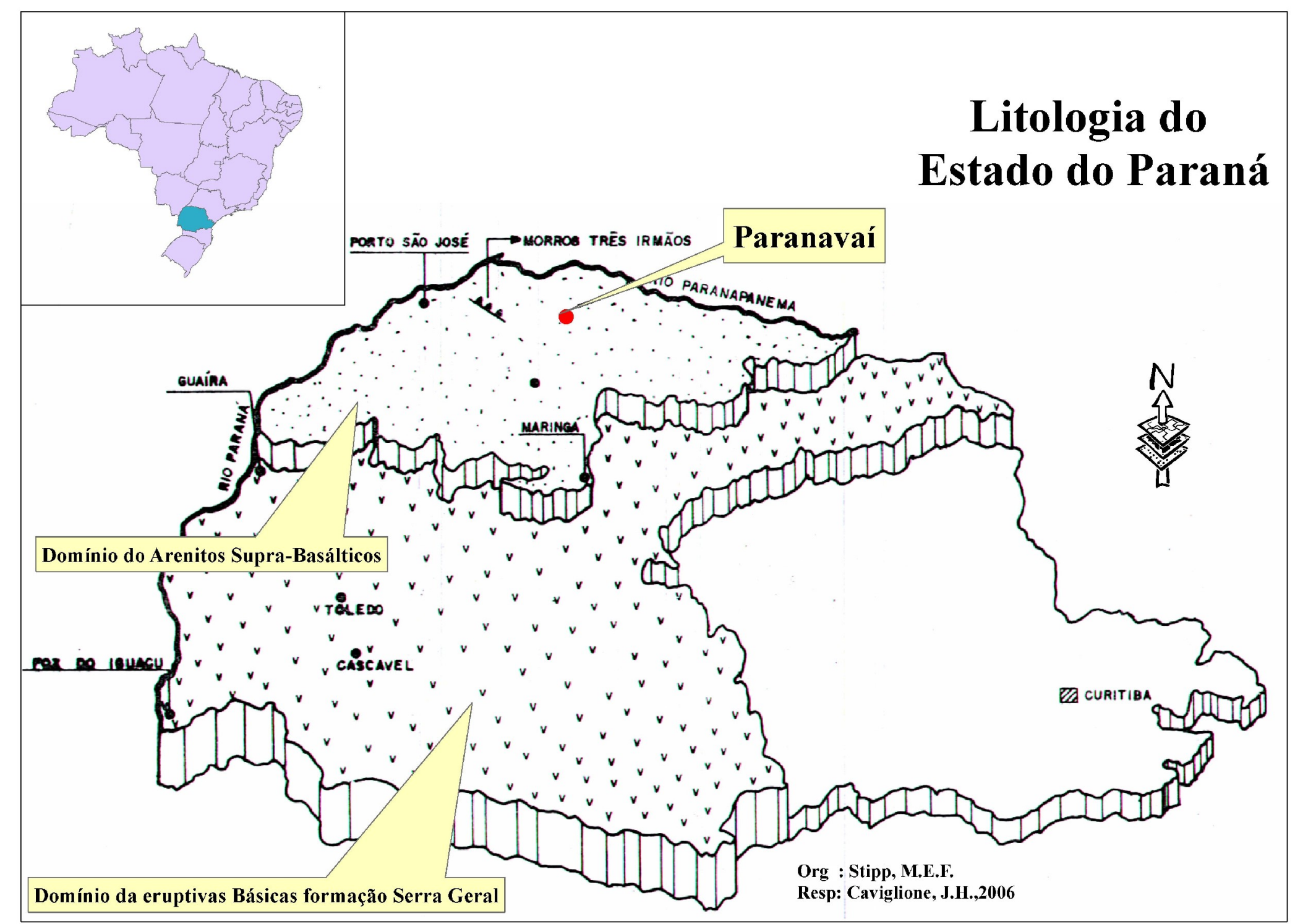

Figura 21. Mapa Litológico do Paraná. Fonte: Santos et al., 1991. 


\subsection{Cobertura Pedológica Regional}

Os solos na região Norte-Noroeste do Paraná apresentam uma íntima relação com o relevo (declividade da vertente) e a rocha (características físicas, químicas e mineralógicas). Gasparetto (2003), estudando a cobertura pedológica que aparece sobre o Arenito Caiuá salienta que nos topos e altas vertentes predominam Latossolos, nas médias vertentes ocorrem os Argissolos que transicionam no sopé para Neossolos Quartzarênicos. Através dos resultados de análises granulométricas e micromorfológicas demonstrou que ao longo das vertentes ocorre transferência de matéria verificando que nos horizontes superiores ocorrem perdas acentuadas de argila e desmantelamento da estrutura pedológica pela remobilização dessa argila. Essas feições são características de coberturas pedológicas em transformação e se evidenciam pela mudança do Latossolo Vermelho em Argissolo Vermelho, a partir da média alta-vertente e, deste, em Neossolo Quartzarênico na base da vertente.

Gasparetto (2003) afirma que:

(...) as variações laterais verificadas na organização da cobertura pedológica, muitas vezes interpretadas como decorrentes de processos de coluvionamento, são resultantes do recuo das cabeceiras de drenagem sobre os interflúvios e do aprofundamento dos vales.

Concluiu que os solos do noroeste do Paraná são originados pelos processos de alteração diretamente do Arenito Caiuá.

De acordo com a EMBRAPA (2002), aparecem nesta região do estado do Paraná as seguintes unidades de solos:

\subsubsection{Solos com Horizonte B Latossólico}

\section{Latossolo Vermelho (eutroférrico e distroférrico)}

São solos profundos, com seqüências de horizonte $A, B$ e $C$, pouco diferenciados, com transições geralmente difusas. Possuem coloração arroxeada, 
são porosos, muito friáveis e acentuadamente drenados. A textura é muito uniforme em todo o perfil, sendo a argila a classe textural dominante, tanto no horizonte $A$, quanto no $B$, com baixo gradiente textural. A porosidade é boa no horizonte superficial e também nos horizontes inferiores.

A consistência com solo seco é ligeiramente dura no horizonte $A$ e macia no horizonte $B$; quando úmido é muito friável e quando molhado é plástico em todo o perfil, é pegajoso tanto no horizonte $A$ como no B.

Aparecem principalmente nos interflúvios com relevo suavemente ondulado e vertente convexa de baixa declividade. Estes solos além de serem profundos, apresentam boas propriedades físicas, o que lhes confere uma boa resistência à erosão. Como o relevo é suavemente ondulado e praticamente plano, com pequena declividade das vertentes, os danos causados pelos fenômenos de erosão são insignificantes, requerendo apenas práticas conservacionistas simples. Entre todos os solos encontrados nesta região, estes são os menos afetados pela ação erosiva.

\section{Latossolo Vermelho Escuro (distrófico e eutrófico)}

São solos bastante profundos, formados a partir de material proveniente de arenitos e rochas básicas; apresentam seqüências de horizontes $A$, B e C pouco diferenciados, com transições geralmente difusas. Possuem coloração vermelha escura, boa porosidade e boa drenagem.

Aparecem com freqüência em relevos suavemente ondulado de vertentes longas e de baixa declividade. A textura varia de franco argilo arenoso a argilo arenoso no horizonte $\mathrm{A}$, a argilo arenoso no horizonte $\mathrm{B}$. O horizonte $\mathrm{A}$ apresenta estrutura moderada, pequena média, granular e grãos simples; no horizonte $\mathrm{B}$ a estrutura é microgranular com aspecto maciço poroso. A consistência quando úmida é quase sempre friável e quando molhada pode ser plástica e pegajosa tanto no horizonte A como no horizonte B. Com relação aos fenômenos erosivos e mecanização estes solos possuem boas características físicas e 
favoráveis como relevo suave e ausência de pedregosidade ou afloramento de rochas, propiciando boas condições para o seu uso.

\section{Latossolo Bruno}

São solos muito profundos formados a partir das rochas eruptivas básicas, apresentam seqüências de horizontes $A, B$ e $C$ pouco diferenciados $e$ transição difusa. A coloração é brunada e a textura é argilosa, com boa porosidade constituindo-se em solos bem drenados. O horizonte A é muito friável com estrutura granular fraca a moderada. O horizonte B apresenta estrutura em blocos subangulares, com grau fraco a moderado.

Aparecem em áreas de relevo suavemente ondulado, principalmente nas regiões de rochas eruptivas básicas. Possuem baixa erodibilidade devido sua ocorrência em áreas de relevo suavemente ondulado e apresentam características morfológicas boas que evitam processos erosivos mais agressivos. Esta unidade é mais freqüente na região sudoeste do estado do Paraná.

\subsubsection{Solos com Horizonte B Textural}

\section{Nitossolos Vermelhos (eutroférrico e distroférrico)}

São solos profundos com seqüência de horizontes $A$, B e C pouco diferenciados e transição geralmente gradual. Apresentam coloração arroxeada, boa porosidade e boa drenagem. O horizonte A possui estrutura granular, fortemente desenvolvida ou em bloco subangulares pequenos também fortemente desenvolvidos. No horizonte B a estrutura é prismática, composta de blocos subangulares médios fortemente desenvolvidos; estas estruturas encontram-se recobertas por cerosidade forte e abundante. O grau de consistência tanto no 
horizonte A como no B é duro quando seco, firme quando úmido e varia de ligeiramente plástico a plástico e pegajoso quando molhado.

Aparecem em relevo suavemente ondulado, ondulado e às vezes planos. Apesar de possuírem boas condições físicas são suscetíveis à erosão, sendo necessário o emprego de práticas conservacionistas conforme o grau de declividade das vertentes. Estes solos são considerados os mais férteis da região.

\section{Argissolos Vermelhos Eutróficos Chernossólicos}

São solos de textura argilosa, coloração arroxeada; cuja profundidade pode chegar até $150 \mathrm{~cm}$. Apresentam horizonte A proeminente ou Chernozênico; a estrutura é granular, com grau de desenvolvimento moderado a forte. Horizonte Bt apresenta estrutura em bloco subangulares, fortemente desenvolvidos e revestidos de cerosidade moderada a comum. A transição é geralmente clara de A para B, e gradual a difusa entre os sub horizontes.

Aparecem em relevo ondulado a fortemente ondulado. Estes solos são suscetíveis à erosão devido à grande declividade das vertentes. Ocorrem principalmente na região sudoeste do estado.

\section{Chernossolos}

Abrange unidades de solos rasos, formado a partir de rochas eruptivas, com seqüências de horizontes $\mathrm{A}, \mathrm{Bt}, \mathrm{C}$ bem diferenciados. A coloração é vermelha escura, acinzentada no horizonte $A$ e bruna avermelhada escura no horizonte $\mathrm{B}$.

A porosidade e drenagem são boas. $O$ horizonte $A$ tem espessura aproximada de $30 \mathrm{~cm}$, com textura argilosa, estrutura granular, moderada, desenvolvida, a consistência é macia, friável, ligeiramente plástica, ligeiramente pegajosa, em solo seco, úmido e molhado. O horizonte Bt é argiloso ou muito 
argiloso; a estrutura é prismática que se desfaz em blocos subangulares, médio, grande, fortemente desenvolvido. Apresenta cerosidade forte a abundante; é duro, firme, plástico e pegajoso em solo seco, úmido e molhado, respectivamente.

Aparecem em relevo fortemente ondulado. São solos suscetíveis à erosão devido à declividade acentuada do relevo. Na área de ocorrência do arenito do Grupo Caiuá, aparecem várias unidades denominadas Podzólicas.

\section{Argissolo Vermelho-Amarelo (eutrófico e distrófico)}

São solos profundos, formados a partir do material originado do Arenito Caiuá. Apresentam seqüências de horizontes A, B e C bem diferenciados e transições geralmente clara ou abruptiva. Possuem coloração avermelhada escura, boa porosidade e boa drenagem.

A textura no horizonte A é geralmente areia ou areia franca, enquanto que no horizonte $B$ predominam as classes texturais franco arenosa e franco argilo arenosa. $O$ horizonte A tem aproximadamente $50 \mathrm{~cm}$ de espessura; a estrutura é franco granular, de grãos simples enquanto que no horizonte $B$, a estrutura se apresenta em blocos sub angulares moderadamente desenvolvidos. A consistência quando úmida é friável ao longo do perfil exceto no horizonte A2. Quando molhada é plástica, não pegajosa no horizonte $A$, variando no $B$ a ligeiramente plástico a plástico e ligeiramente pegajoso a pegajoso. Nas unidades de solos que apresentam transição abrúptica, aparecem com freqüência cerosidade fraca ou moderada, recobrindo as estruturas. Essas características são observadas nos perfis localizados principalmente a partir da média vertente para jusante.

Aparecem nas partes baixas do relevo e acompanham os canais de drenagem natural, podendo ocorrer também nas partes mais elevadas.

Devido à textura leve no horizonte $A$ estes solos são suscetíveis aos processos erosivos, principalmente nos locais em que as feições do relevo permitem o escoamento superficial das águas da chuva, com velocidade suficiente para 
arrastar as partículas dos solos. Para o controle da erosão torna-se necessário práticas conservacionistas intensivas.

\subsubsection{Neossolos Litólicos}

São solos rasos com profundidade de 20 a $30 \mathrm{~cm}$, apresentando seqüência de horizontes $A, C$. Sobre as rochas do Arenito Caiuá estes solos apresentam coloração clara, textura arenosa e estrutura granular. Nas áreas das rochas eruptivas básicas a coloração é mais avermelhada escura, textura argilosa e estrutura granular.

Aparecem geralmente nas áreas de relevo com vertentes de alta declividade, zonas de relevo bastante dissecado pela rede de drenagem ou nos morros isolados da região. O controle da erosão é muito difícil, necessitando de práticas conservacionistas intensivas e adequadas.

\subsubsection{Neossolos Flúvicos}

São solos jovens, formados a partir de sedimentos inconsolidados. Apresentam horizonte A e seqüência de camadas estratificadas, de coloração variada. A textura varia muito de acordo com o sedimento. Nas bordas das ilhas do Rio Paraná ou margens dos grandes rios aparece sucessão de camadas mais arenosas que se intercalam com camadas areno argilosas ou argilo arenosas.

Aparecem em terrenos planos e nos terraços fluviais.

\subsubsection{Neossolos Quartzarênicos}

São solos profundos, formados a partir de materiais provenientes do arenito. Apresentam seqüência de horizontes A e C; são porosos, soltos, 
excessivamente drenados e a coloração é vermelho amarelado. A textura é arenosa a areia franca, não apresentando estrutura.

Aparecem em relevo suave ou plano. São muito suscetíveis à erosão.

\subsubsection{Gleissolos Háplicos}

São solos que estão sob a influência do lençol freático na superfície ou próximo dele, durante um período do ano. Existe excesso de água no perfil, a coloração é matizada devido à matéria orgânica e ocorrem fenômenos de oxidação e redução.

Aparecem em relevo plano, próximo à rede de drenagem vales dos rios ou lugares de água estagnada durante um período do ano. Não apresentam problemas de erosão devido à forma do relevo. Para melhor aproveitamento de algumas unidades que apresentam maior fertilidade se recomenda técnicas de drenagem adequada. 


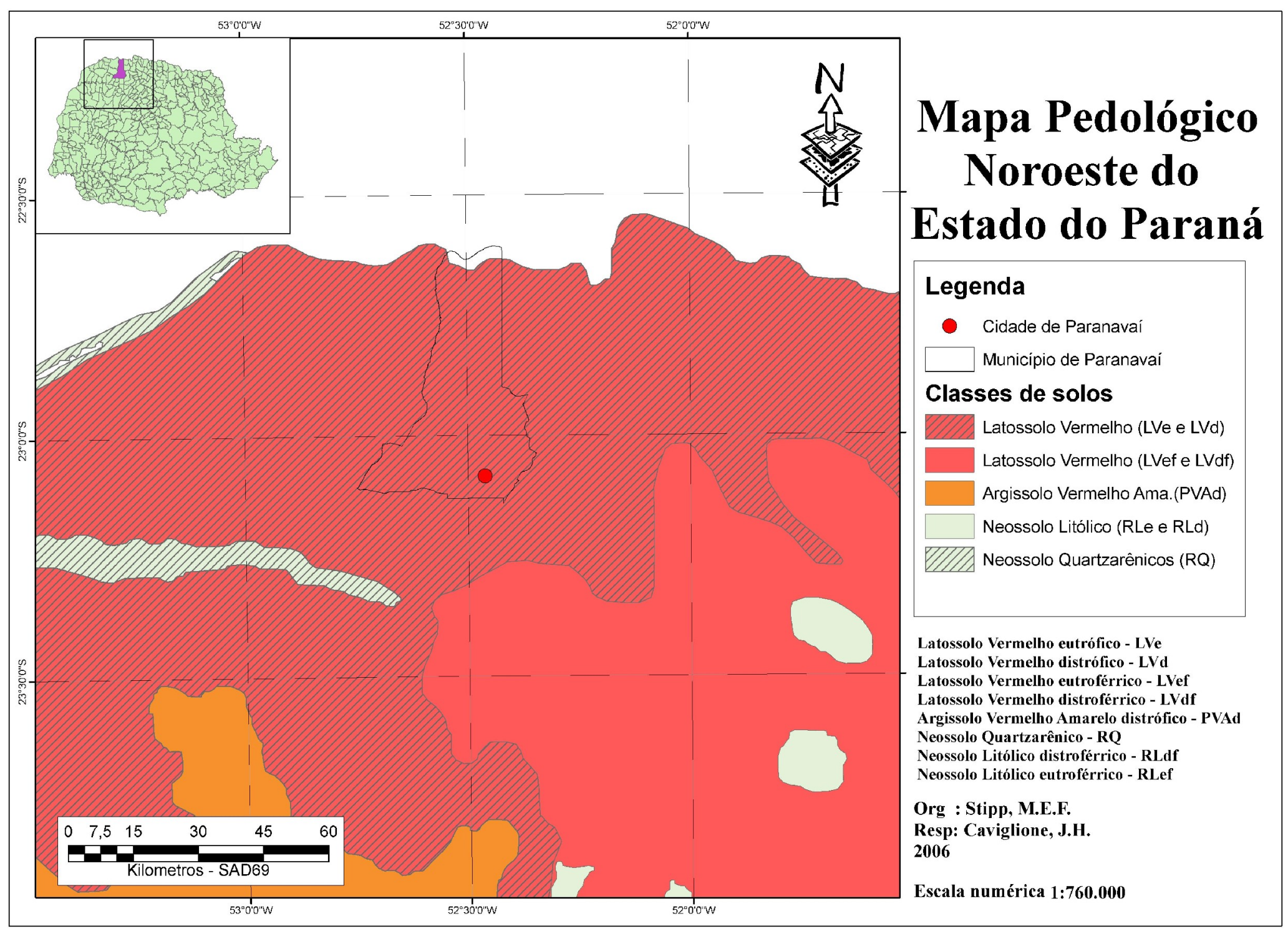

Figura 22. Mapa de Solos do Noroeste do Paraná. 


\subsection{CoBertuRA PEDOLÓGICA dA ÁREA DE ESTUdo.}

Como a área de estudo está inserida no subplanalto de Apucarana que é integrante do Terceiro Planalto Paranaense, procedeu-se à descrição das seqüências de solos desta região.

Segundo NAKASHIMA \& NÓBREGA(2003), o Subplanalto de Apucarana abrange toda a rede de drenagem da margem direita do Rio Ivaí, a Bacia do Rio Pirapó e pequenos afluentes do Rio Paranapanema. As áreas mais elevadas próximas à serra do Cadeado apresentam altitudes aproximadas de $1000 \mathrm{~m}$, decrescendo em direção aos rios Paranapanema e Paraná.

No setor Noroeste desse subplanalto as rochas vulcânicas (basaltos) estão recobertas pelo Arenito Caiuá, originando através do processo pedogenético conjuntos de solos com características morfológicas, químicas, físicas e mineralógicas bem diferenciadas.

Nas áreas onde o relevo é suavemente ondulado (áreas das rochas basálticas) predominam os Latossolos Vermelhos, textura argilosa nos topos e altas vertentes. A partir daí em direção à jusante aparecem os Nitossolos Vermelhos nas médias e baixas vertentes. Nas áreas do Arenito Caiuá, nos topos e altas vertentes aparecem em geral o Latossolo Vermelho textura arenosa, média e nas baixas e médias vertentes aparece o Argissolo Vermelho-Amarelo ou o Argissolo Vermelho, ambos com textura arenosa média.

Nas áreas de pequenas colinas arredondadas onde predomina maior declividade nas vertentes, nos topos e médias vertentes ocorre o Nitossolo Vermelho e nas baixas vertentes, o Neossolo Litólico. Em algumas vertentes de maior declividade o Neossolo Litólico ocorre desde o topo até a baixa vertente e no sopé pode ocorrer o Nitossolo. Neste caso estes solos foram desenvolvidos por materiais transportados e depositados nesses locais, formando colúvios. (NAKASHIMA \& NÓBREGA, 2003).

Nas áreas do Arenito Caiuá ocorrem os Latossolos Vermelhos textura arenosa média, principalmente nos topos e altas vertentes e os Argissolos 
Vermelhos-Amarelos ou Argissolos Vermelhos com textura arenosa média que ocorrem nas médias e baixas vertentes.

O Latossolo Vermelho, textura arenosa média, aparece também em relevo com topos planos, ligeiramente convexos, vertentes longas de $800 \mathrm{~m}$ a $1200 \mathrm{~m}$ de comprimento e declividades que variam de $3 \%$ a $8 \%$. Esses solos têm profundidade superior a $300 \mathrm{~cm}$, exibindo seqüências de horizontes $A-B w-C$ pouco diferenciados, geralmente com transição difusa plana. A coloração é geralmente Bruno-Avermelhada no horizonte A e Vermelho-Escura no horizonte B. A estrutura no horizonte $A$ é fraca, moderada a moderadamente desenvolvida. A consistência é ligeiramente dura a dura, quando seco, ligeiramente friável ou friável quando úmido e ligeiramente plástica e pegajosa quando molhado. São solos geralmente bastante permeáveis onde a presença de ferro é na maioria das vezes baixa, inferior a $9 \%$. (EMBRAPA-IAPAR, 1984).

Os Argissolos Vermelhos-Amarelos, textura arenosa média apresentam profundidades que variam de 100 a $200 \mathrm{~cm}$. Ocorrem geralmente nas médias e baixas vertentes, apresentando em geral seqüências de horizontes A-E-BtC ou A-E-Bt-Bw-C. A coloração é variada desde vemelho-amarelada a vermelhoescura. Predomina um nítido contraste de cores entre os horizontes e a transição entre eles se faz geralmente de forma gradual ou abrúptica.

A estrutura no horizonte A é granular, fraca, com grãos simples; a consistência é fraca, não plástica, não pegajosa. O horizonte $E$ é na maior parte das vezes, claro com grãos soltos muito porosos. O horizonte $\mathrm{Bt}$ é mais argiloso, com estrutura subangular, fraca-moderada; sua consistência é ligeiramente dura, friável, ligeiramente plástica e ligeiramente pegajosa. A ocorrência de cerosidade é freqüente nesses solos. Em análises granulométricas elaboradas pela EMBRAPAIAPAR (1984), apontam para Paranavaí um teor de argila que varia de $7 \%$ no horizonte A, $4 \%$ no horizonte E e $25 \%$ no horizonte Bt.

Ainda de acordo com Nakashima \& Nóbrega (2003), em várias áreas do noroeste paranaense os Argissolos apresentam uma coloração mais avermelhada devido a um teor mais elevado de ferro, o que permite classificá-los como Argissolos Vermelhos. São morfologicamente semelhantes aos Argissolos 
Vermelhos-Amarelos, apresentando freqüentemente seqüência de horizontes A-Bt-C e mais raramente A-E-Bt-C. Nas áreas do Arenito Caiuá os Argissolos predominam ao longo de toda vertente, passando em alguns casos, como em áreas de cabeceiras de drenagem e setores de baixa vertente a Neossolos Quartzarênicos.

\subsection{HIDROGRAFIA}

O Município de Paranavaí está inserido na dinâmica de duas grandes bacias do noroeste do estado, as bacias dos rios Paranapanema e Ivaí.

A sede urbana do município localiza-se entre as nascentes dos ribeirões Paranavaí e Surucuá afluentes do rio Ivaí.

O rio Paranapanema representa a divisa entre Paranavaí e o estado de São Paulo se destacando como a principal bacia do município. O rio Ivai não chega a penetrar no município, isso só acontece com alguns de seus afluente como os ribeirões Paranavaí e Surucuá.

Entre os cursos d'água que banham o município pode-se destacar:

\section{Bacia do Rio Paranapanema:}

- Ribeirão São João e seus afluentes:

- Córrego Pitangatuba;

- Córrego Mucupi;

- Córrego Marisol;

- Córrego Piracegi;

- Córrego Mira;

- Córrego Alegria; 
- Córrego Água Jeanine;

- Córrego São Pedro;

- Água São João;

- Córrego Prata;

- Córrego Santa Clara;

- Córrego Areia Branca;

- Córrego Água Mandaguari;

- Água Boaventura;

\section{Bacia do Rio Ivaí:}

- Ribeirão Surucuá e seus afluentes:

- Córrego Tapir

- Córrego Piuva

- Córrego Amoreira

- Córrego Tanejava

- Córrego Ouro Verde

- Córrego Saira

- Ribeirão Paranavaí e seus afluentes

- Córrego Pavãozinho

- Córrego Xaxim

- Córrego São Sebastião 
- Ribeirão das Araras

- Ribeirão Floresta

- Ribeirão Vinte e Dois

- Ribeirão Água da Mata

- Ribeirão Água Vandrenssem

- Córrego Vinte e Oito

- Córrego Bicudo

- Córrego Água Sociedade

- Córrego Água Seminário

- Córrego Santa Mônica

- Córrego Água Pires

- Ribeirão Paixão. 


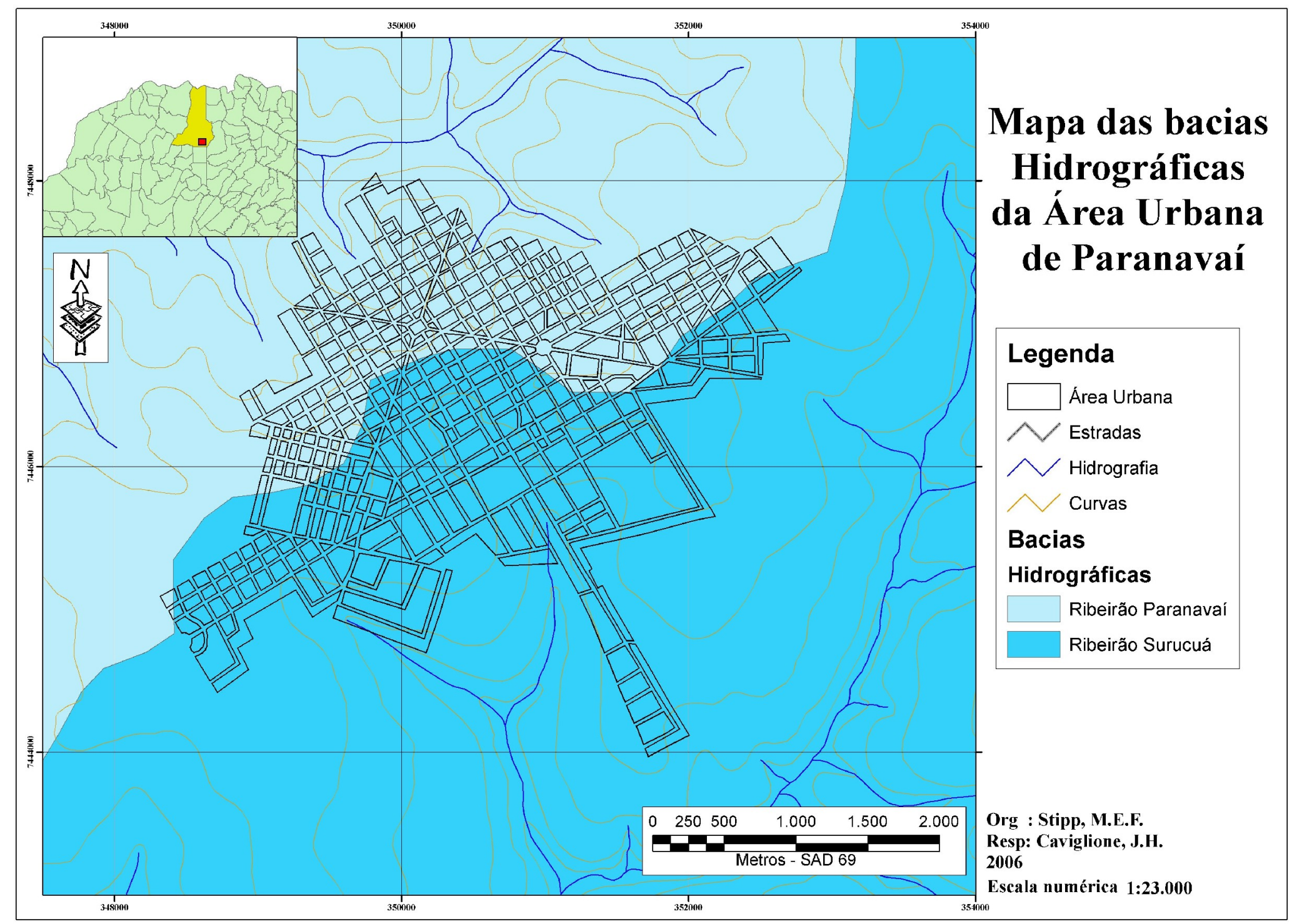

Figura 23. Carta Hidrográfica da área. 


\section{CARACTERIZAÇÃO HUMANA E ECONÔMICA}

\subsection{URBANIZAÇÃO}

O município de Paranavaí apresentava em 2000, uma população de 75.750 habitantes, correspondendo $11,81 \%$ do total da mesorregião noroeste paranaense, situando-se como o segundo maior dessa região do estado.

Caracterizando-se pelo elevado grau de urbanização, 92,84\%, superior à média estadual, de tal forma que em sua extensa área rural encontravamse apenas 5.421 habitantes, $7,16 \%$ de sua população total (Tabela 6).

Tabela 6. Distribuição da População Total Urbana e Rural - Município de Paranavaí 2001.

\begin{tabular}{c|c|c}
\hline Pop. Urbana & Pop.Rural & Total \\
\hline 70.329 & 5.421 & 75.750 \\
\hline
\end{tabular}

Fonte: IBGE -2001

A sede do município, que compreende a zona urbana propriamente dita, encontra-se atualmente subdividida em bairros, jardins ou loteamentos. De modo geral essas áreas abrigam uma população numericamente próxima, porém guardam importantes diferenças, particularmente quanto às condições sócioeconômicas de seus moradores e do patamar de urbanização da área em termos de infraestrutura e serviços. É importante destacar que o Jardim São Jorge conta com maior número de habitantes, 12.342 , embora no Centro a densidade populacional se apresente bem mais elevada. 


\subsection{CaracterizaçÃo Demográfica}

No decorrer dos últimos trinta anos, que demarcaram o grande impulso na dinâmica migratória do Paraná, principalmente da região noroeste com intensos fluxos de saída de população, o município de Paranavaí tem mantido o ritmo de sua população total crescente, não obstante, a maioria das cidades da região revelem perda populacional em percentuais que não thes permitem sequer acompanhar os baixos níveis de crescimento registrados para o total do Estado.

Essa situação está fundamentalmente associada à elevada perda de população rural que, entre 1970 e 2000, registrou uma diminuição de 18.078 para 5.418 habitantes (Tabela 7).

Tabela 7. População Total Urbana e Rural Paranavaí - Paraná 1970 - 2000.

\begin{tabular}{c|c|c|c}
\hline \multirow{2}{*}{ ANOS } & \multicolumn{3}{|c}{ POPULAÇÃO } \\
\cline { 2 - 4 } & TOTAL & URBANA & RURAL \\
\hline 1970 & 57.387 & 39.309 & 18.078 \\
\hline 1980 & 65.290 & 54.666 & 10.624 \\
\hline 1991 & 71.052 & 64.354 & 6.698 \\
\hline 2000 & 75.663 & 70.245 & 5.418 \\
\hline
\end{tabular}

Fonte: IBGE Censo Demográfico

De acordo com os dados oficiais do município, constatou-se que a perda de população rural e o conseqüente crescimento populacional urbano se deram não somente por fatores econômicos, mas também pelo fator educacional.

Muitas pessoas se deslocam para estudar em centros urbanos maiores e não retornam. Por sua vez a capacidade de absorção da população nas áreas urbanas, bastante significativa no início do período também vêm decrescendo, revelando uma fraca capacidade de incorporação e retenção de novos segmentos. 
O contingente populacional alcançado, de mais de 70 mil habitantes, propiciou a disponibilização de oportunidades de comércio e serviços que ativa e estimula o dinamismo ali existente, assinalando grandes possibilidades de potencialização das perspectivas regionais.

Ainda em termos de população urbana é importante chamar atenção para o fato de que mesmo diante de um processo lento de crescimento geral os espaços intra-urbanos são afetados diferentemente. Apesar da sede urbana de Paranavaí apresentar um ritmo de crescimento lento, o loteamento Santos Dumont, ao lado da Faculdade de Filosofia de Paranavaí (FAFIPA) se destaca com um crescimento maior que as demais áreas, devido às condições particulares criadas pela presença da faculdade que se constitui em atrativo estimulando o crescimento em seu entorno.

\subsection{ECONOMIA}

O Município de Paranavaí foi criado pela Companhia de Terras do Norte do Paraná tendo como atividade econômica inicial a extração de madeira. Posteriormente, a atividade de cultivo do café ganhou importância como base de sustentação da economia local. Assim, o extrativismo e a monocultura constituíram a gênese das atividades produtivas que configuraram o município.

A agricultura pode ser caracterizada pela citricultura que é uma das mais recentes alternativas agrícolas da região.

Sua implantação começou nos anos 2000/2001, e transformou Paranavaí no maior produtor de laranjas do Paraná. A safra de 2002/2003 alcançou 6 milhões de caixas de laranjas (estimativa baseada na quantidade vendida para as duas indústrias instaladas no município).(IBGE 2004).

A antiga Citrocoop, indústria de beneficiamento de suco de laranja foi comprada pela Paraná Citrus, e a Citri - Indústria, Comércio e Exportação LTDA que hoje são as responsáveis pela transformação da laranja. Praticamente todo o 
suco produzido nas indústrias é exportado, como também dois sub-produtos da laranja, - óleo essencial e o D'limoneno.

No mercado interno, o suco abastece as indústrias de refrigerantes. Além disto, a laranja in natura é comercializada nos estados do Paraná, Santa Catarina, Rio Grande do Sul e Mato Grosso do Sul.

A região de Paranavaí também é produtora de mandioca, algodão, café, bicho-da-seda, abacaxi e soja. Dessas, a produção de mandioca é a mais significativa. É a segunda maior do estado e ocupa 30 mil hectares. A produtividade da região é duas vezes superior que a média nacional. $\mathrm{Na}$ região se colhe, em média, 30 toneladas por há, sendo que a média brasileira é de 13 toneladas por ha. (IBGE, 2004).

O café ocupa ainda grande parte da área rural, cerca de 14 mil hectares de lavouras, e pode-se notar um crescimento bastante significativo devido a implantação do sistema de café adensado, que está trazendo de volta a cafeicultura para o Noroeste do estado.

Outra importante fonte econômica é a criação do bicho da seda, cultura que gera muitos empregos. São duas mil toneladas de casulos de bicho da seda produzidos na região, comercializados nas indústrias de fiação de seda.

A agropecuária é bastante expressiva na região, onde se pode destacar a pecuária de corte.

Paranavaí possui na sua zona rural cerca de $75 \%$ da área voltada para a pastagem, onde o rebanho chega aproximadamente 1 milhão e 100 mil cabeças, com o predomínio da raça nelore.

Na região, ocorreu a introdução de búfalos, que atualmente é o segundo maior rebanho de bubalinos do Paraná.

Para atender o consumo de carne, Paranavaí conta com dois grandes frigoríficos com capacidade de abate de 1400 bois por dia. São aproximadamente 450 toneladas de carne por dia, que abastecem os estados do Paraná, São Paulo, Santa Catarina, Rio Grande do Sul e Rio de Janeiro. Juntos, os 
frigoríficos geram mais de 650 empregos diretos e estão prontos para colocar seus produtos no Mercado Comum Europeu.

Ao longo da pesquisa sobre a economia de Paranavaí, pode-se notar que ela ainda mantém forte dependência de alguns setores e empreendimentos.

A atividade que tem mais representativa contribuição econômica para Paranavaí, está situada no setor industrial, que responde por cerca de $52 \%$ do Valor Adicionado Fiscal - VAF (IBGE, 2004).

Comparando a participação destes setores no VAF do Município, verifica-se que o desempenho do setor secundário, no entanto, é o que possui menor representação no VAF-2000 do Paraná (0,35\%).

Esta aparente contradição sugere que a expansão da produção industrial de Paranavaí, embora importante para economia local, vem demonstrando um desempenho acanhado, em comparação com os números globais do Estado.

Tabela 8. Valores da Participação econômica no Município de Paranavaí/Paraná valores absolutos nos anos 1990 e 2000.

\begin{tabular}{l|c|c|c|c}
\hline & \multicolumn{2}{|c|}{ VALORES ABSOLUTOS } & PARTICIPAÇÃO RELATIVA \\
\cline { 2 - 5 } & $\mathbf{1 9 9 0}$ & $\mathbf{2 0 0 0}$ & $\mathbf{1 9 9 0}$ & $\mathbf{2 0 0 0}$ \\
\hline Indústria & 2.249 .877 .685 .00 & 83.535 .407 .00 & $37.44 \%$ & $52.24 \%$ \\
\hline Comércio & 3.190 .045 .907 .00 & 46.464 .086 .00 & $53.09 \%$ & $29.05 \%$ \\
\hline Serviços & 569.142 .311 .00 & 29.918 .988 .00 & $9.47 \%$ & $18.71 \%$ \\
\hline Total & 6.009 .065 .903 .00 & 159.918 .481 .00 & $100.00 \%$ & $100.00 \%$ \\
\hline
\end{tabular}

Fonte: Plano Diretor da Prefeitura Municipal de Paranavaí, 2001.

Cerca de $60 \%$ da produção industrial está concentrada em produtos alimentares, o que indica forte dependência do município da agroindústria, principalmente da produção de derivados da mandioca, fato esse que se repete com a indústria de sucos em se tratando do cultivo de cítricos. 
Ao longo desses últimos anos, a indústria de produtos alimentares de Paranavaí vem se constituindo no mais importante ramo industrial, tendo expandido em $9 \%$ a sua participação nesse período (Tabela 8 ).

Outro ramo industrial relevante é o moveleiro que representa $5 \%$ da produção industrial do Município. A madeira utilizada para essa atividade por muito tempo vinha da região do Mato Grosso, e agora foi substituída pelas oriundas dos estados de Rondônia e Acre.

Cerca de 30 estabelecimentos são de microempresas de móveis (fundo de quintal) e existem 3 empresas importantes que atendem: (a) mercados institucionais (setor bancário) para todo o Brasil, (b) fabricação de móveis padronizados para escritórios e (c) produção mediante pedido (Plano Diretor, 2001).

O setor têxtil e o de confecções (vestuário, artefatos de tecido e calçados) são importantes para o setor industrial, mas representados por microempresas cuja qualidade se situa fora dos padrões estaduais e nacionais, devido ao baixo investimento e especialização da mão de obra envolvida.

O município conta com quatro cooperativas que agregam indústrias de confecção (duas em fase de implementação) que produzem para outras marcas de (São Paulo), mas com possibilidade de expansão para várias regiões, e indústrias com marcas próprias.

É importante destacar que enquanto a produção têxtil da maior indústria local é comercializada para uma empresa paulista, a indústria de confecção se obriga a importar tecidos de outros municípios e regiões, evidenciando um índice frágil de agregação de valor, que também se reflete no setor do couro.

Entre as atividades comerciais mais importantes, verifica-se que somente duas (supermercados e lojas de tecidos e vestuários) possuem alguma relação com o perfil da produção industrial local. 


\section{DESENVOLVIMENTO DA PESQUISA APLICADA}

O processo de medição foi desenvolvido de dois em dois meses no decorrer de 1 ano.

Conjuntamente foram analisados os índices pluviométricos da área, para se relacionar com a movimentação do solo.

Com orientação da Carta de Fragilidade Ambiental, elegeram-se 5 pontos de medição em áreas onde os maiores problemas estão relacionados à falta da mata ciliar, galerias de água pluvial que causam assoreamento e grandes voçorocas.

Verificou-se que um dos principais motivos desses problemas é a precariedade das galerias de captação das águas pluviais o que provoca intenso processo erosivo. 


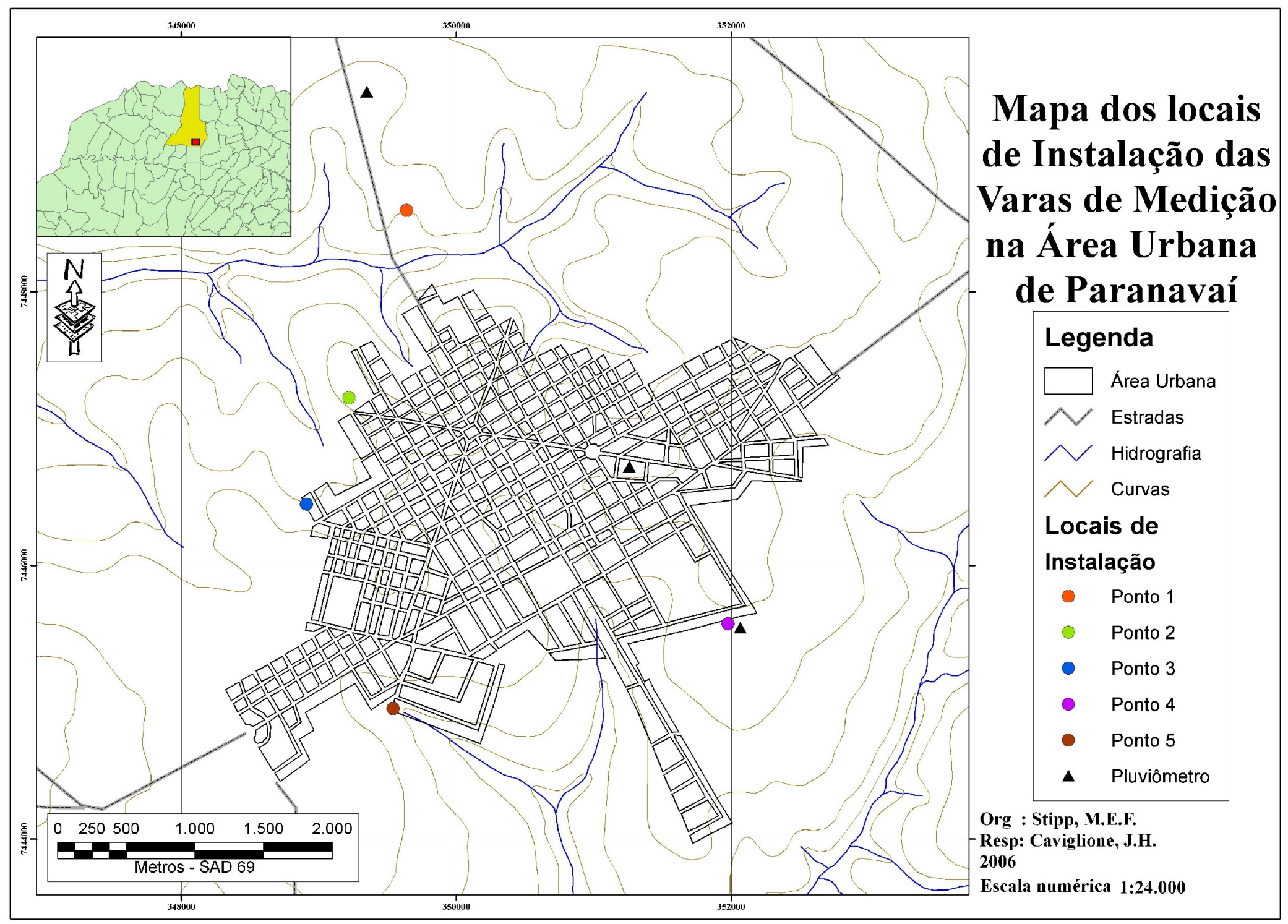

Figura 24. Mapa de Localização dos Pontos de Medição e Pluviômetros. 


\subsection{CaRacterizaÇÃo dos Pontos de Medição}

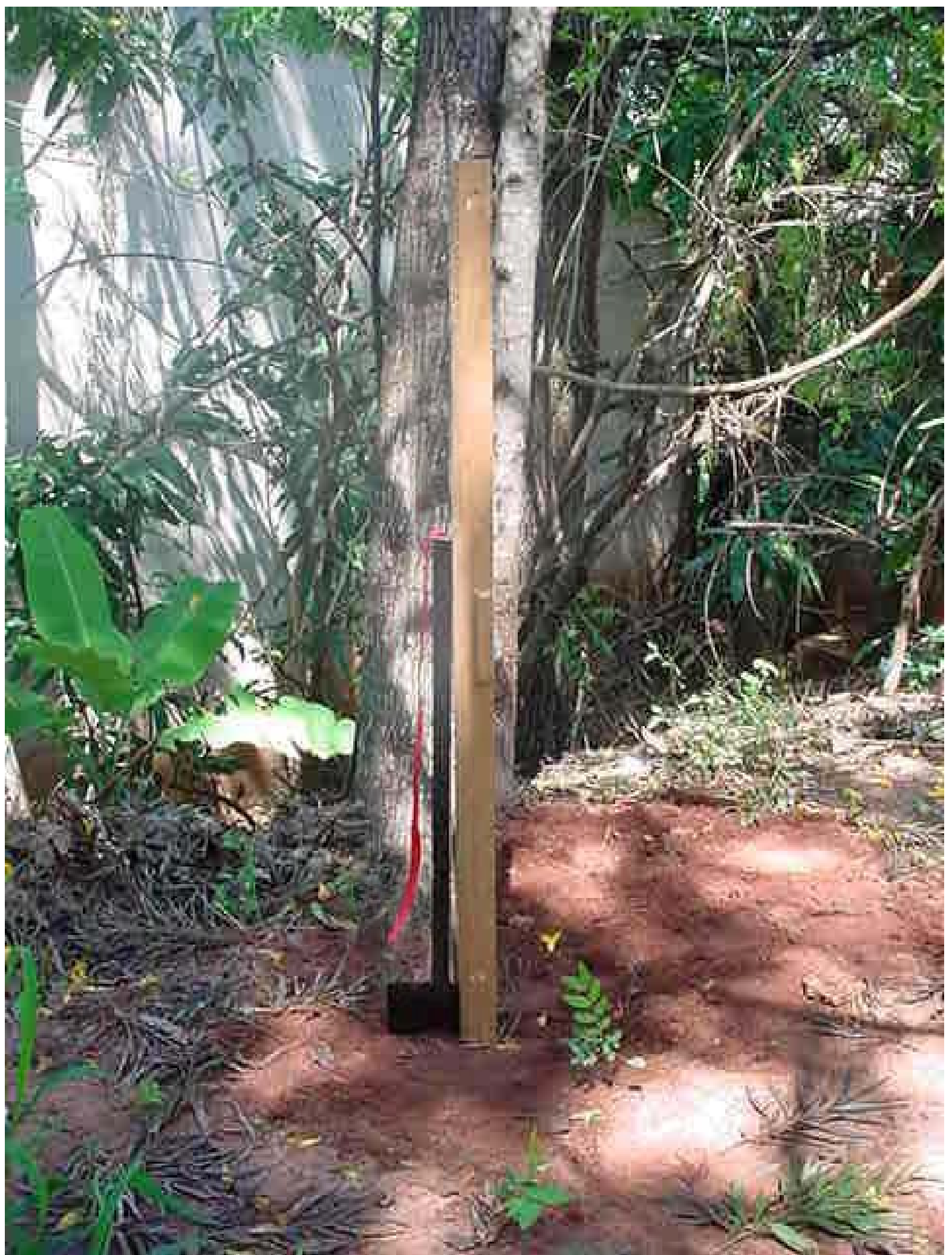

Figura 25. Foto do $1^{\circ}$ ponto de amostragem. Autor: STIPP, M. E. F., 2003. 


\section{Caracterização do Ponto 01}

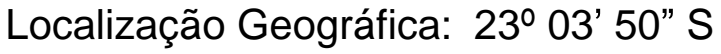

$52^{\circ} 28^{\prime} 05^{\prime \prime} \mathrm{W}$

Este ponto foi instalado na Rua Guanabara № 371 esquina com a Rua Ronaldo D.S. Azevedo no Parque Morumbi - Face Norte.

O local apresentava-se com cobertura vegetal de grevilhas, sem gramíneas, cercada com edificações de um pavimento, com ocorrência de assoreamento na parte norte, presença de erosão (Voçorocas) tendo como obra de contenção a construção de um muro de arrimo.

O solo aqui foi caracterizado como Argissolo Vermelho - escuro a moderado; textura de areia ou areia franco/franco arenosa ou franco argilo arenosa de 5 a 10\% de declive (Carta de Solos da área, IAPAR, 1988).

O Ponto faz parte da Bacia do Ribeirão Paranavaí; com a hipsometria variando entre 400 - 420 metros (bege) e a declividade de 5 a $10 \%$ (Laranja). 


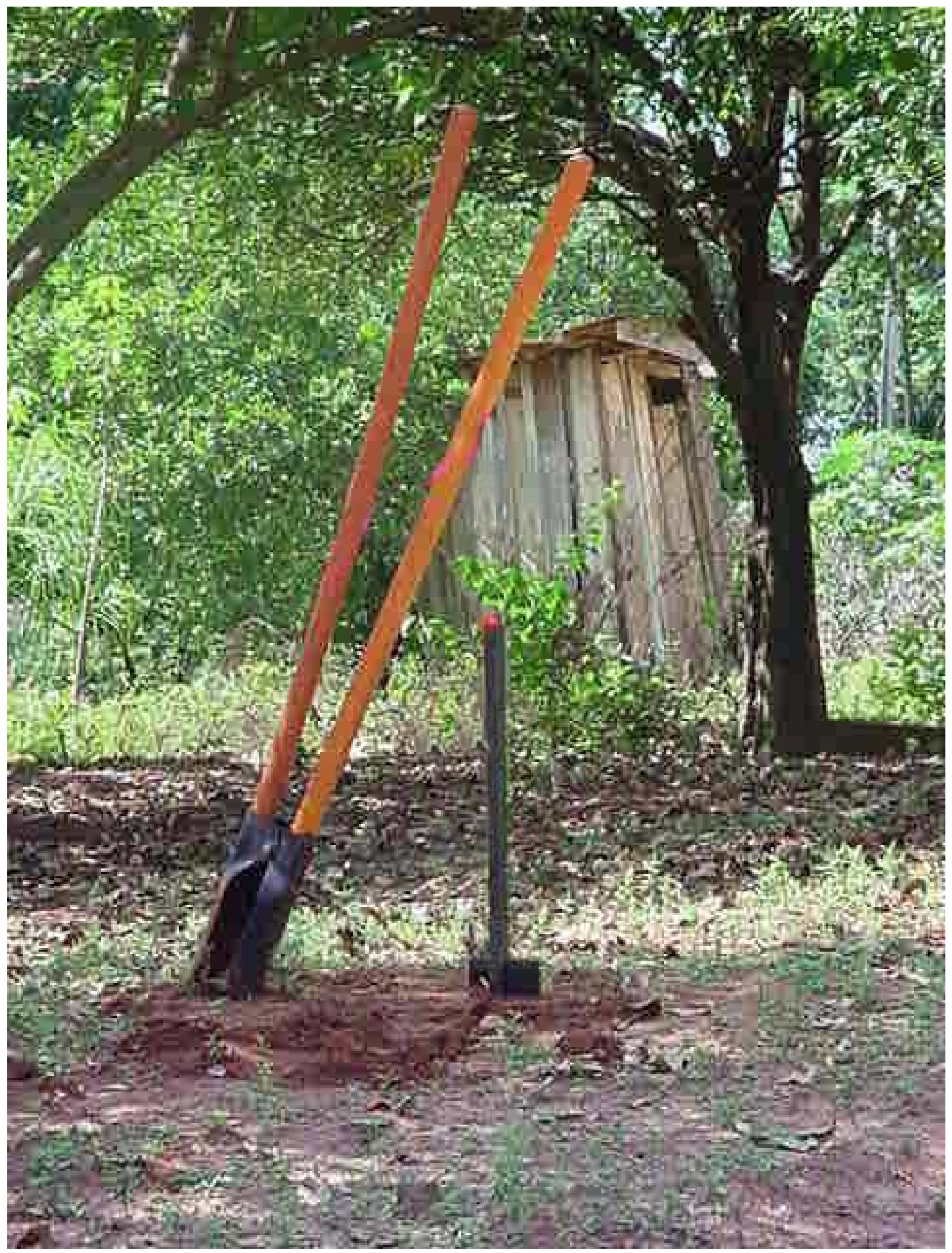

Figura 26. Foto do $2^{\circ}$ ponto de amostragem. Autor: STIPP, M. E. F., 2003. 


\section{Caracterização do Ponto 02}

Localização Geográfica: 23 04’ 06” S

$52^{\circ} 27^{\prime} 20^{\prime \prime} \mathrm{W}$

O Ponto 02 foi instalado na Rua Rio Grande do Sul com o cruzamento da Avenida Tancredo Neves, final do conjunto Ouro Branco nos fundos.

O local é caracterizado por apresentar vegetação de árvores frutíferas, com inexpressiva vegetação rasteira - Face Sul.

O solo neste lugar foi identificado como Argissolo Vermelho escuro a moderado, textura areia ou areia franco/franco arenosa ou franco argilo arenosa com 5 a 10\% de declive (Carta de Solos da área, IAPAR, 1988).

A área se encontra na Bacia do Ribeirão Paranavaí, sua hipsometria varia entre 420-440 metros de altitude em relação ao nível do mar (Laranja) a declividade varia entre 5 a 10\% (Laranja). 


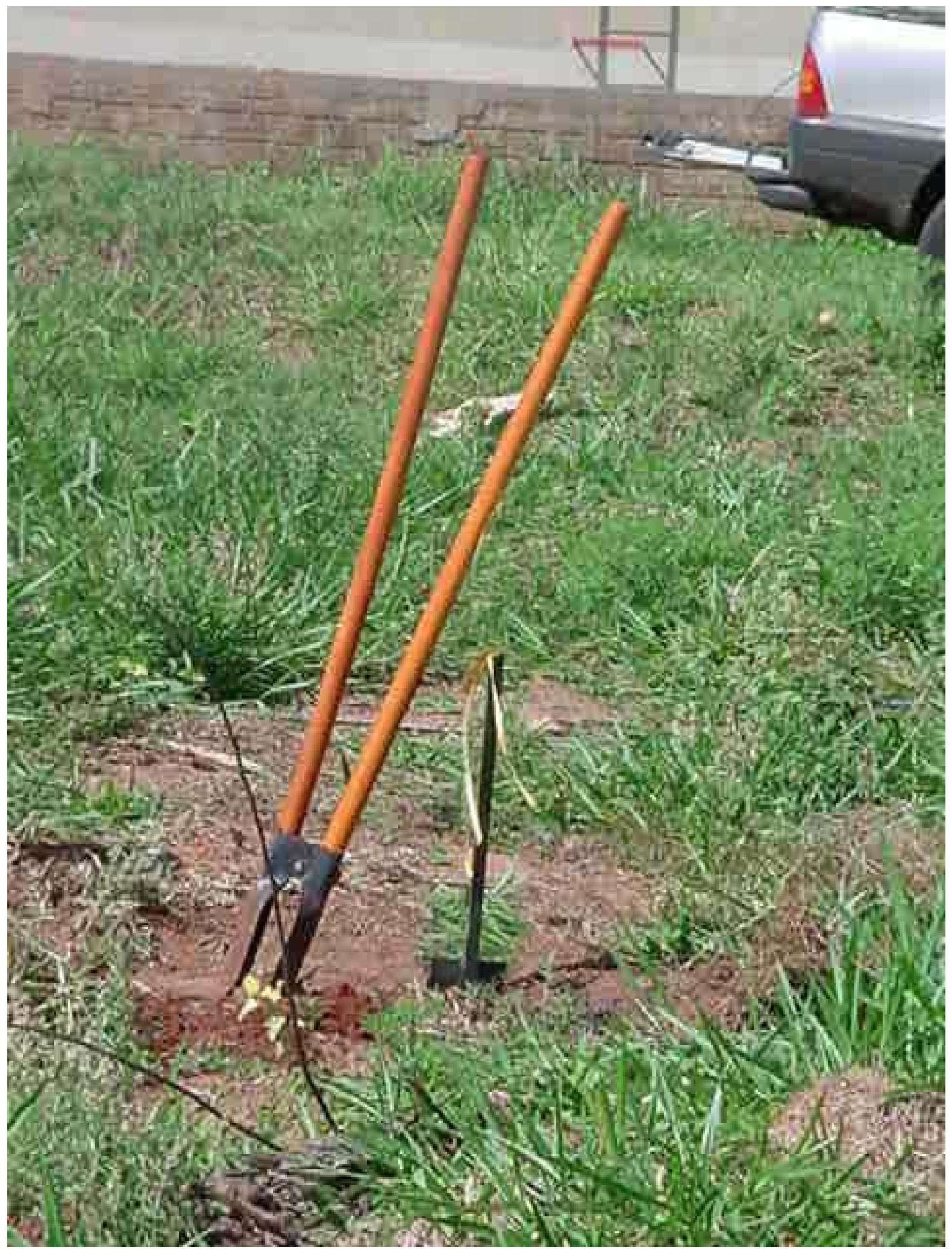

Figura 27. Foto do 3 º ponto de amostragem. Autor: STIPP, M. E. F., 2003. 


\section{Caracterização do Ponto 03}

Localização Geográfica: 23 04' 34" S

$52^{\circ} 23^{\prime} 25^{\prime \prime} \mathrm{W}$

O Ponto 03 foi instalado na Avenida Tancredo Neves com o cruzamento da Rua Amazonas na Face Sul.

O local é caracterizado por apresentar vegetação de gramíneas em toda a extensão do terreno.

O solo aqui foi identificado como Neossolos Flúvicos a moderado;

textura areia ou areia franco com 1 a $5 \%$ de declive (Carta de Solos da área, IAPAR, 1988).

A área se encontra na Bacia do Ribeirão Paranavaí, sua hipsometria varia entre 440-460 metros de altitude em relação ao nível do mar (Vermelho escuro) e a declividade varia entre 10 a $20 \%$ (vermelha). 


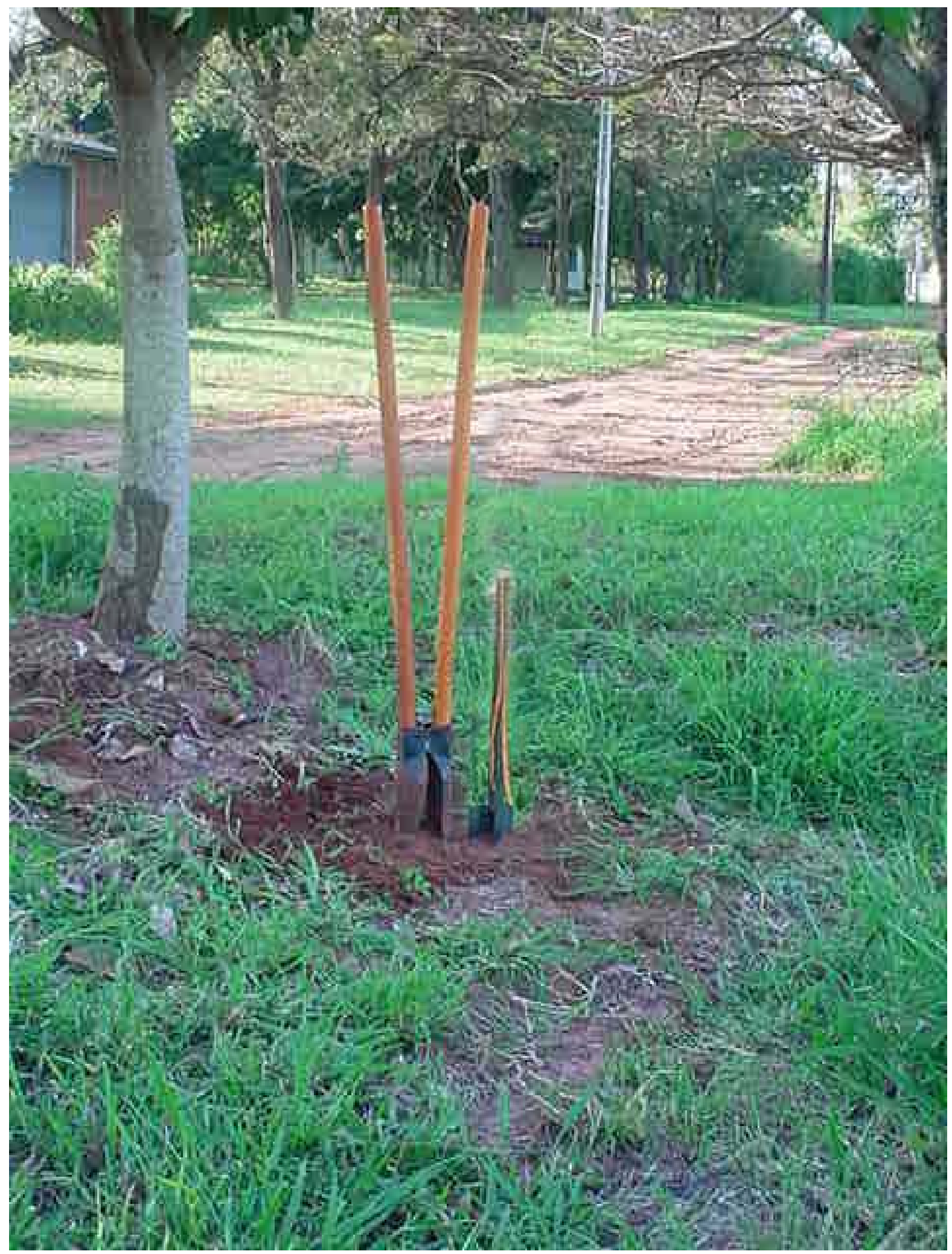

Figura 28. Foto do $4^{\circ}$ ponto de amostragem. Autor: STIPP, M. E. F., 2003. 


\section{Caracterização do Ponto 04}

Localização Geográfica: 23ำ05’ 34,3” S

$52^{\circ} 26^{\prime} 29,7$ " W

O Ponto 4 foi instalado no Instituto Agronômico do Paraná (IAPAR), situado na Rua Paulo Antonio Costa s/n, no Jardim Ipê - Face Sul.

O local apresenta vegetação predominante de pastagem, com gramíneas e árvores.

O solo deste ponto foi identificado como Latossolo Vermelho escuro a moderado; textura areia ou areia franco/franco arenosa com 0 a $5 \%$ de declive (Carta de Solos da área, IAPAR, 1988).

A área se localiza na Bacia do Ribeirão Surucuá, sua hipsometria varia entre 480-500 metros de altitude em relação ao nível do mar (Marrom claro) e apresenta uma declividade de até $2 \%$ (amarelo claro). 


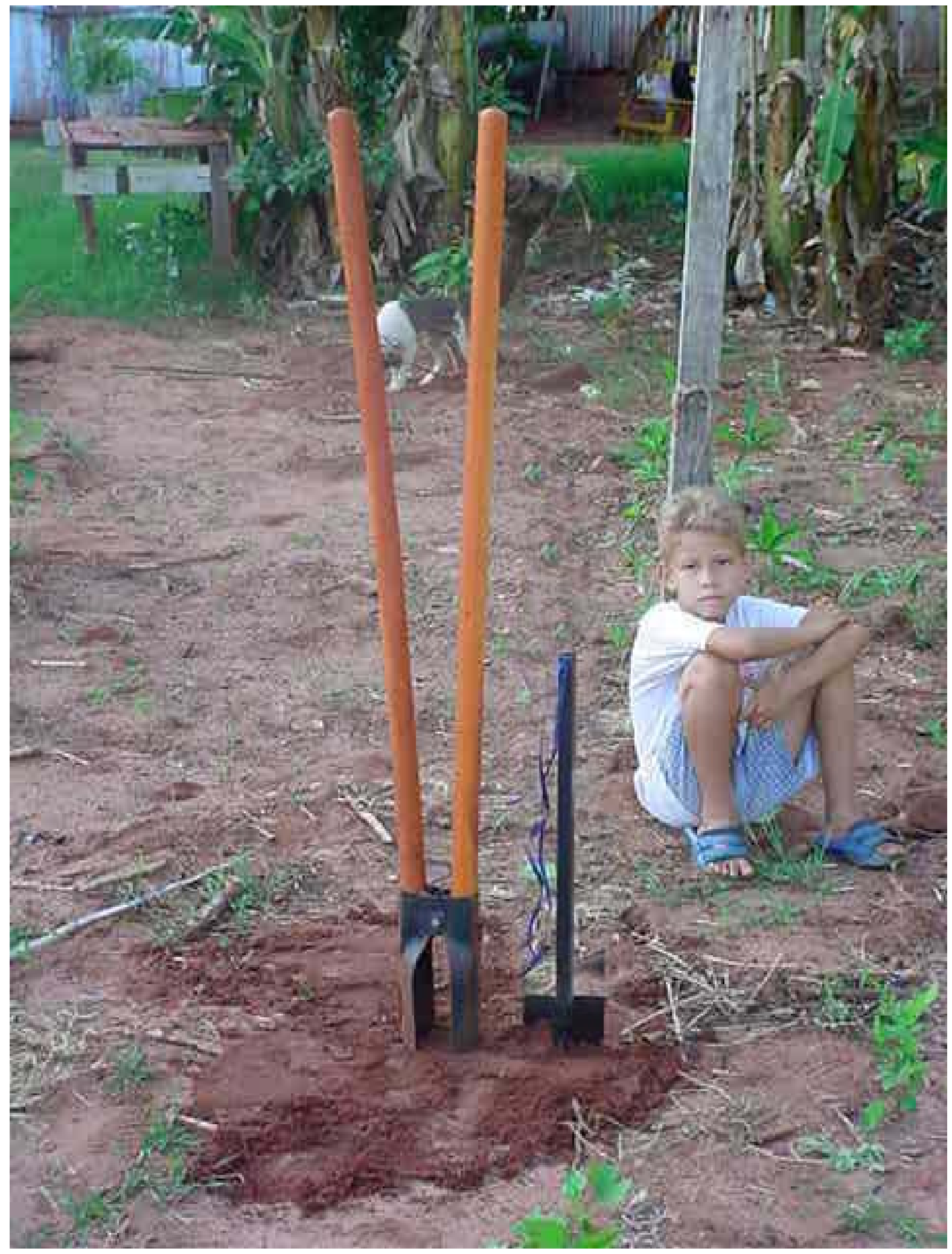

Figura 29. Foto do 5 ponto de amostragem. Autor: STIPP, M. E. F., 2003. 


\section{Caracterização do Ponto 05}

Localização Geográfica: 23ำ 05’ 04” S

$52^{\circ} 28^{\prime} 15,5^{\prime \prime} \mathrm{W}$

O Ponto 05 foi instalado na Rua Monteiro Lobato $n^{\circ} 300$, fundos com a Rua Barão do Rio Branco.

O local é caracterizado por apresentar Horta familiar, com plantio de batata, mandioca e um pequeno pomar de bananeiras.

O solo foi identificado como Argissolo Vermelho Escuro, abrupto a Moderado; textura areia ou areia franco/franco arenosa ou franco argilo arenosa com 5 a 10\% de declive (Carta de Solos da área, IAPAR, 1988).

A área se encontra localizada na Bacia do Ribeirão Surucuá, sua hipsometria varia entre 420-480 metros de altitude em relação ao nível do mar (Laranja) e a declividade oscila de 5 a 10\% (Laranja). 
9.2 Confecção das CaRtas Temáticas 


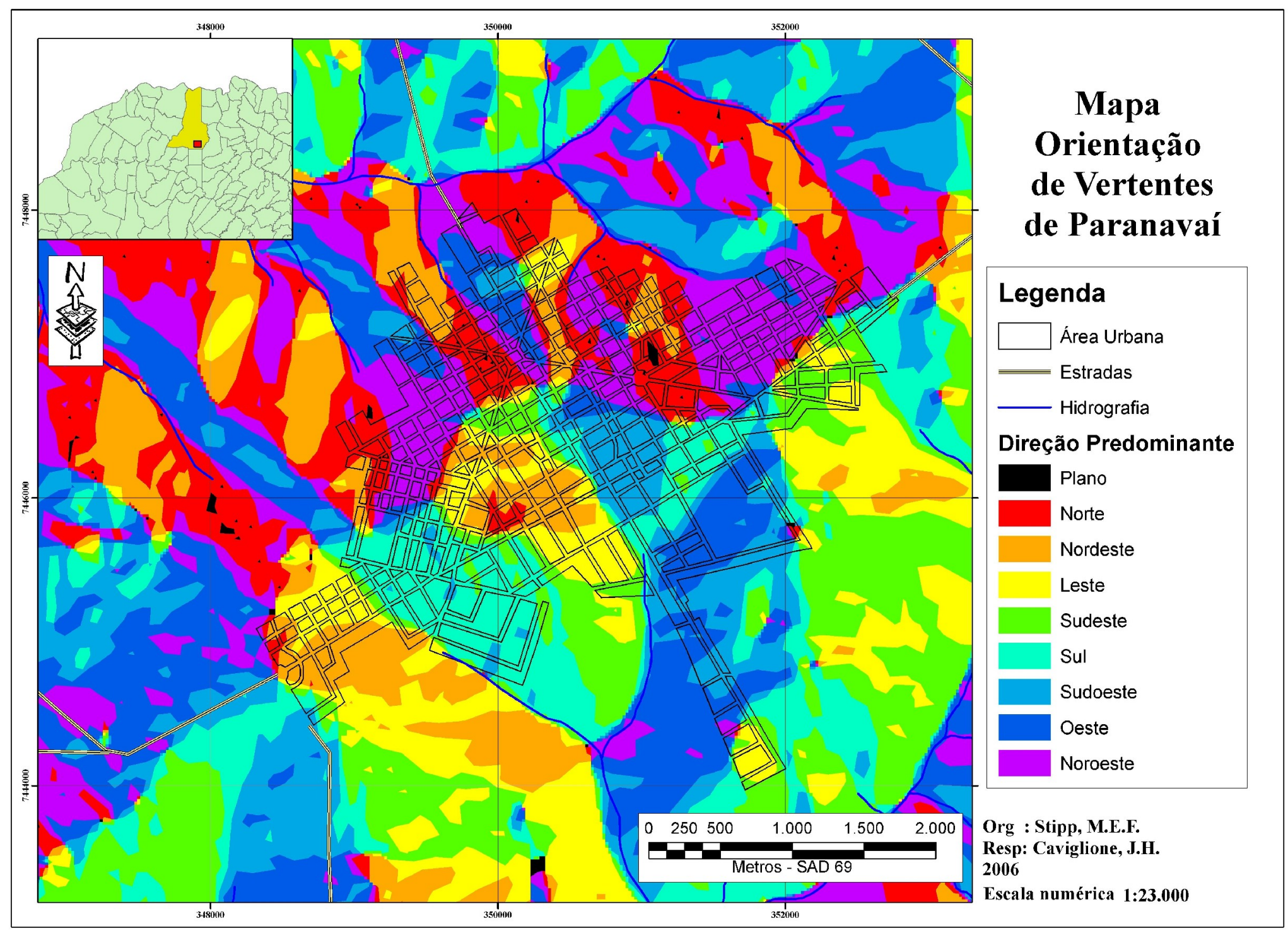

Figura 30. Carta de Orientação de Vertentes. 


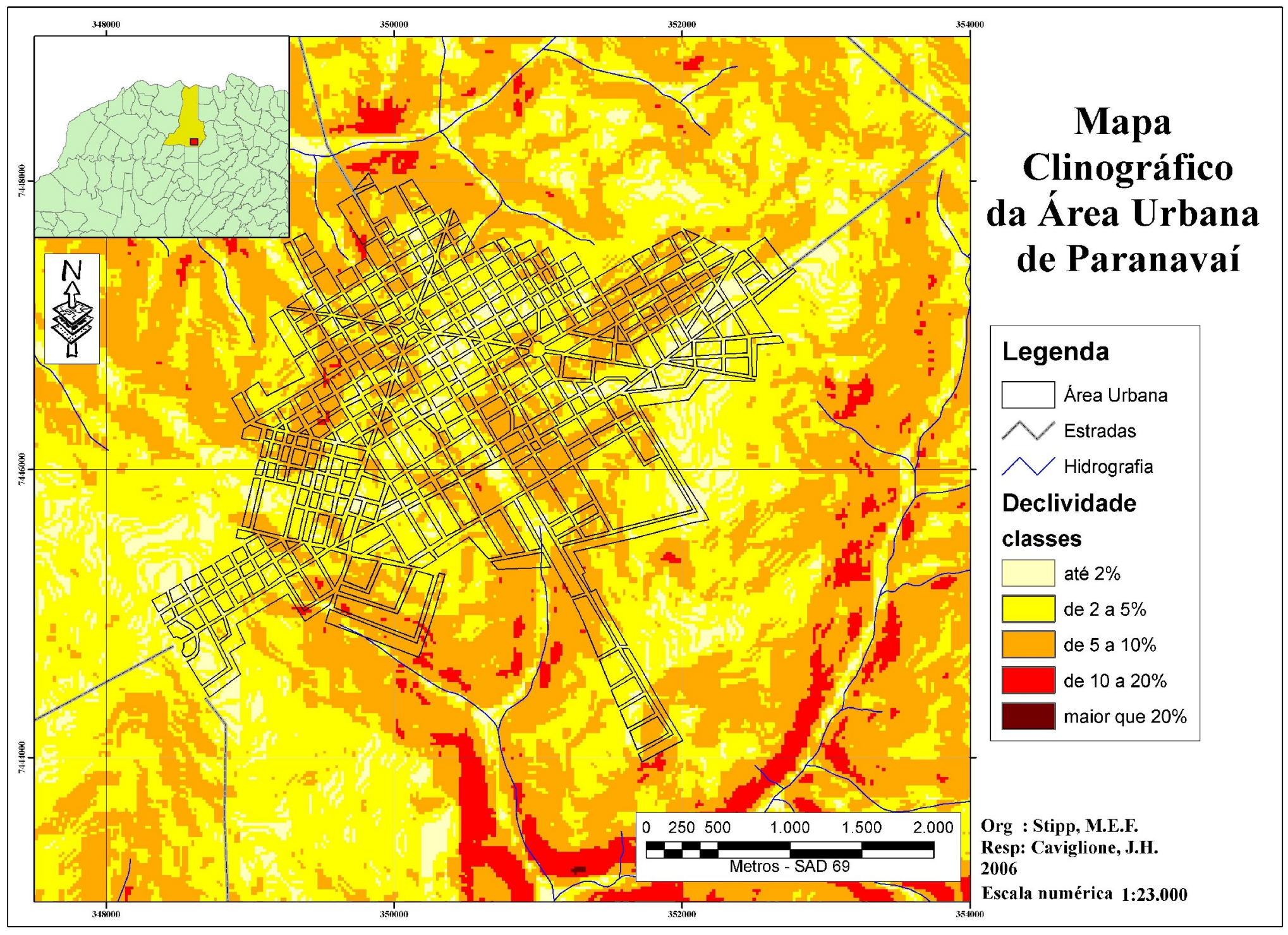

Figura 31. Carta de Declividade da Área Urbana. 


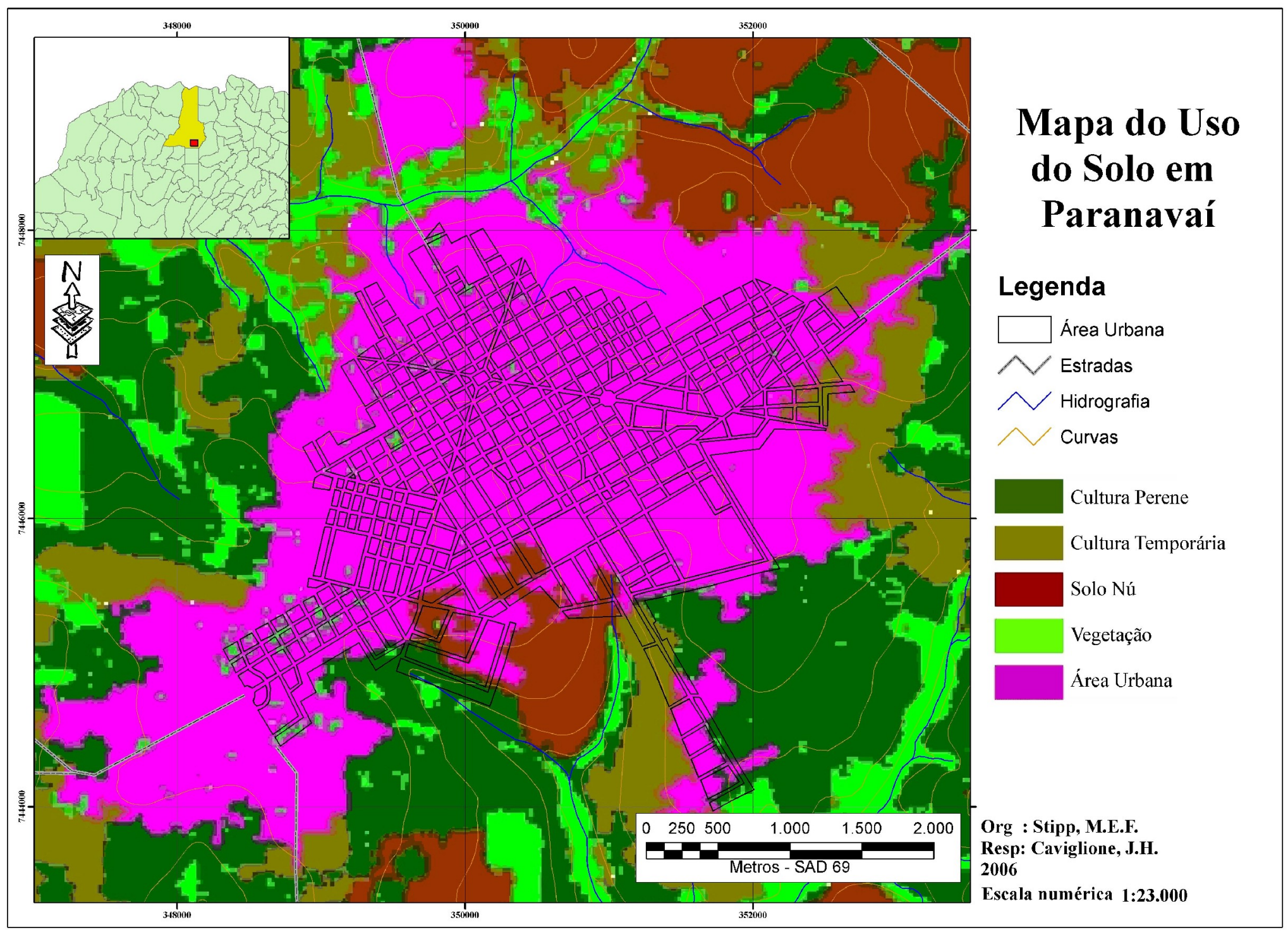

Figura 32. Carta do Uso da Terra. 


\section{RESULTADOS}

\subsection{Principais Processos Erosivos Identificados em Paranavaí}

Paranavaí teve seus assentamentos iniciais locados sobre espigões, o que determinou uma maior energia hídrica devido ao deslocamento superficial das águas até chegar aos vales receptores. Conseqüentemente sua área urbana se tornou cenário de processos erosivos, ravinas e voçorocas, pelo fato de estar inserida na área do arenito Caiuá.

Problemática da área - Registro Fotográfico

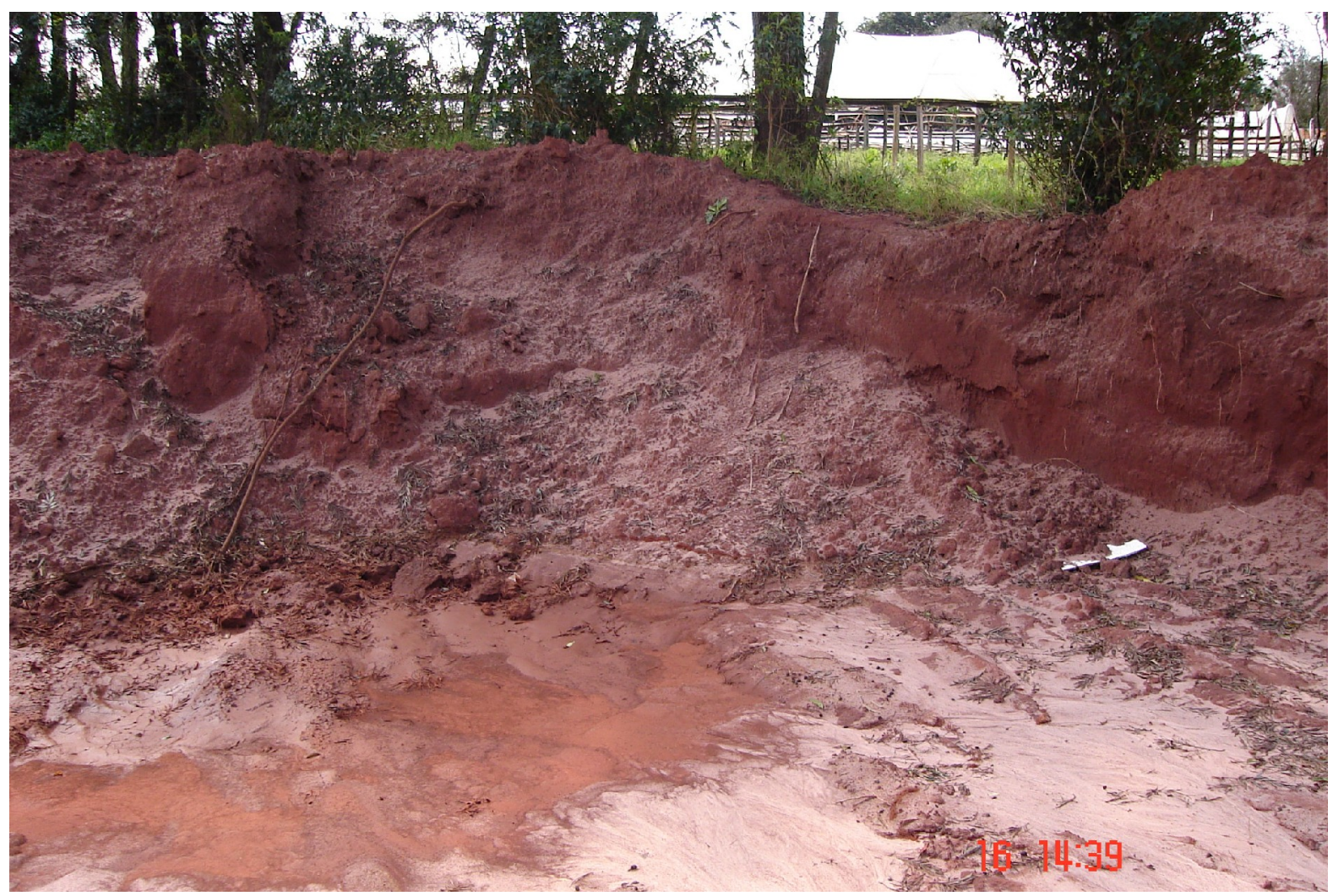

Figura 33. Exemplo do fenômeno da arenização típico na região. Autor: STIPP, M. E. F., 2006. 


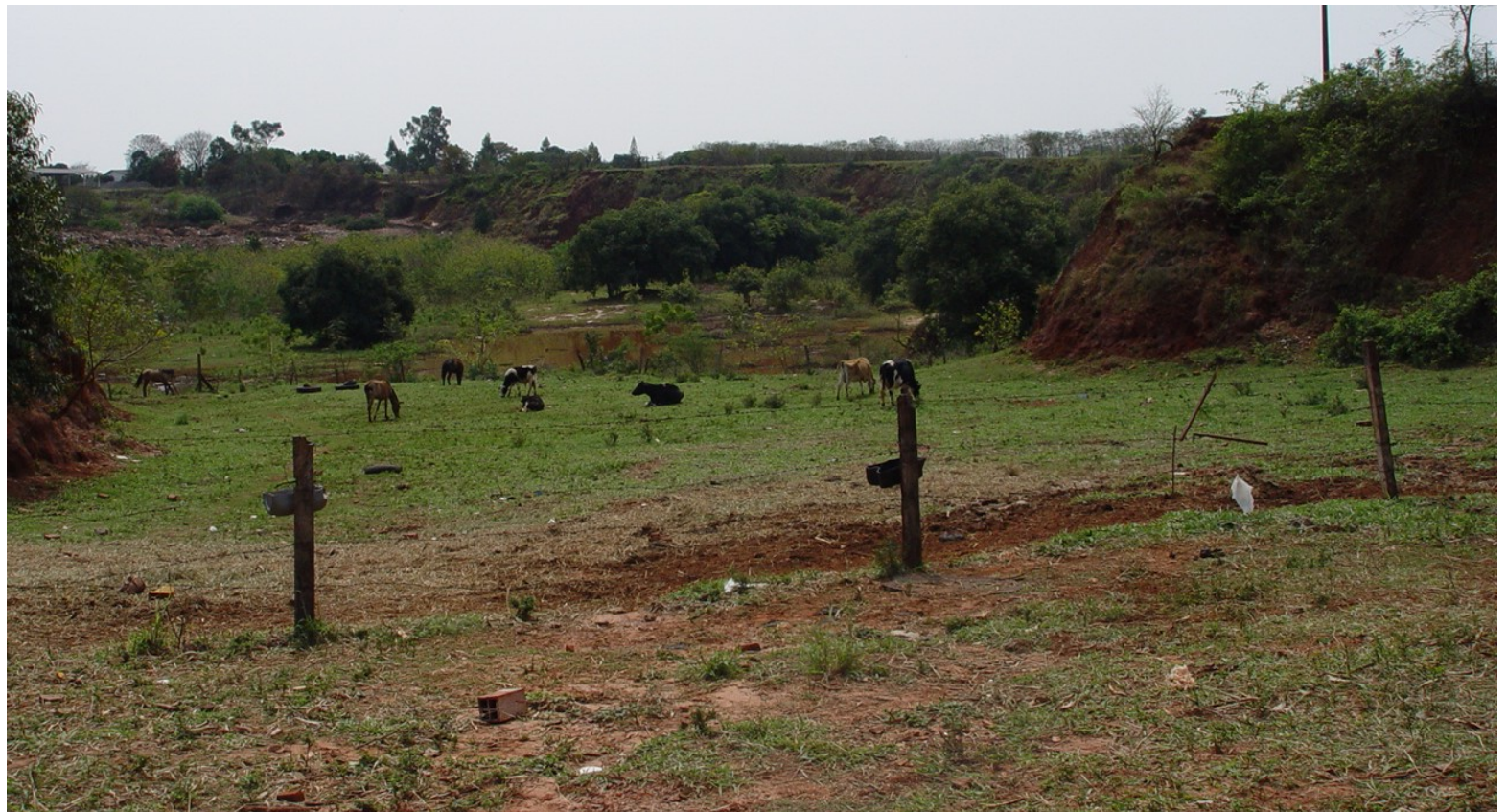

Figura 34. A textura mais arenosa das camadas superficiais dos solos, favorece a formação de sulcos, que se não forem devidamente controlados podem desenvolver processos erosivos mais agressivos como os ravinamentos que pode ser o embrião de uma voçoroca. Autor: STIPP, M. E. F., 2006.

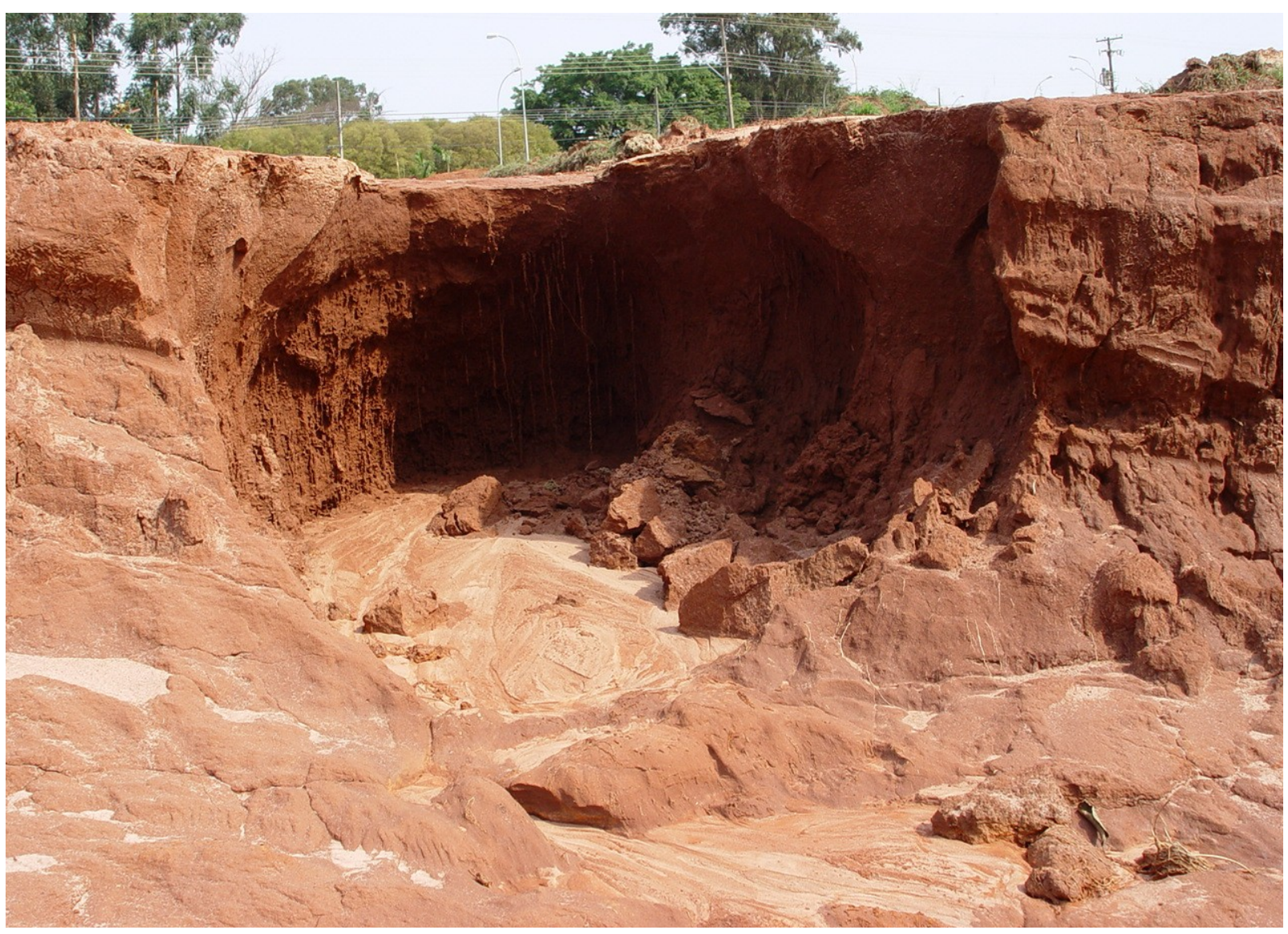

Figura 35. Aspecto geral de uma voçoroca que já atingiu o nível de base. Autor: STIPP, M. E. F., 2006. 


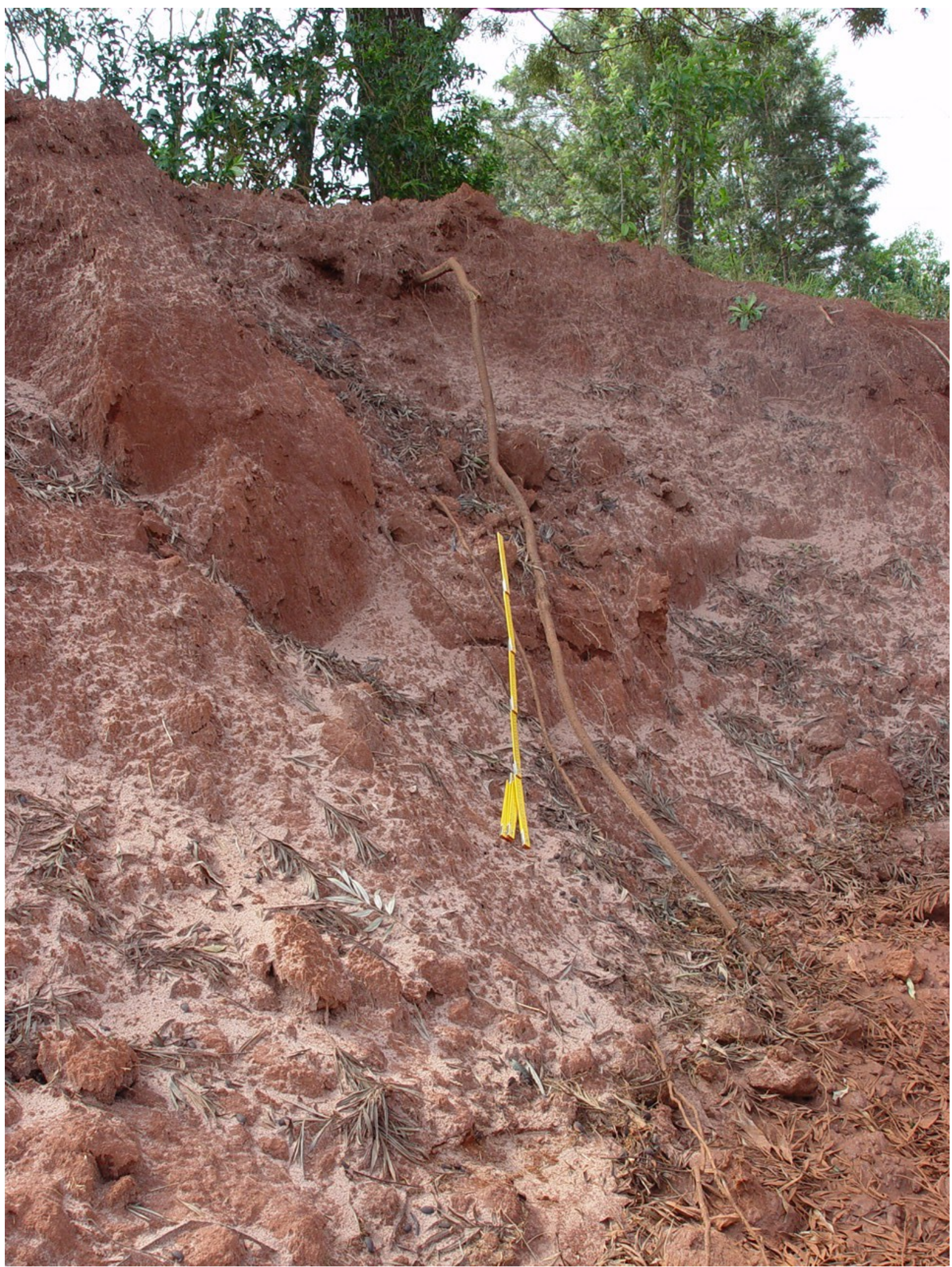

Figura 36. Nos topos arredondados as vertentes são mais convexas e quando estão desprotegidas pela falta de vegetação, criam condições de instabilidade (movimentos de massa dos solos) como a figura acima. Autor: STIPP, M. E. F., 2006. 


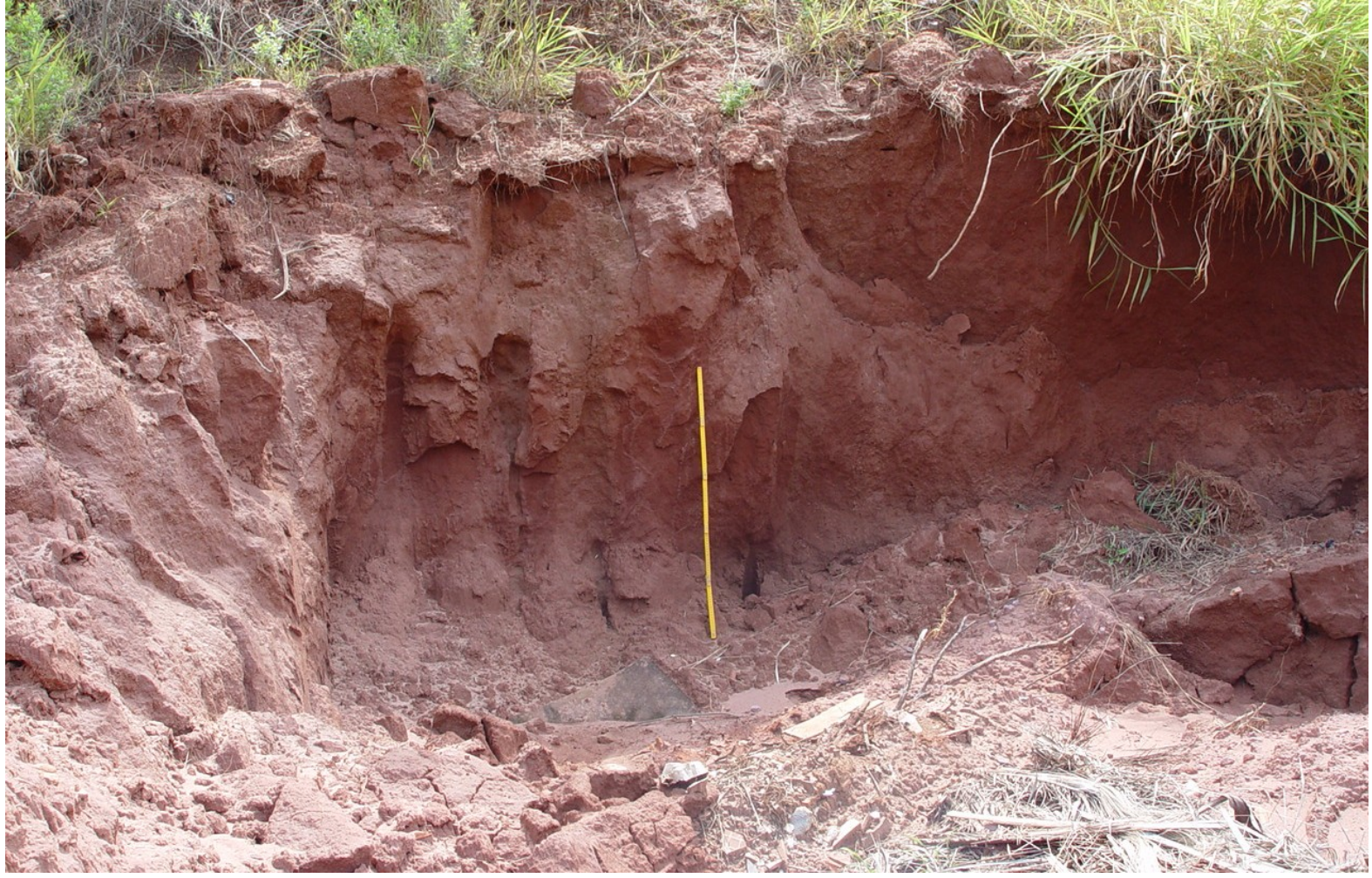

Figura 37. Aspecto de uma voçoroca localizada ao lado de uma rua na entrada da cidade de Paranavaí. Autor: STIPP, M. E. F., 2006.

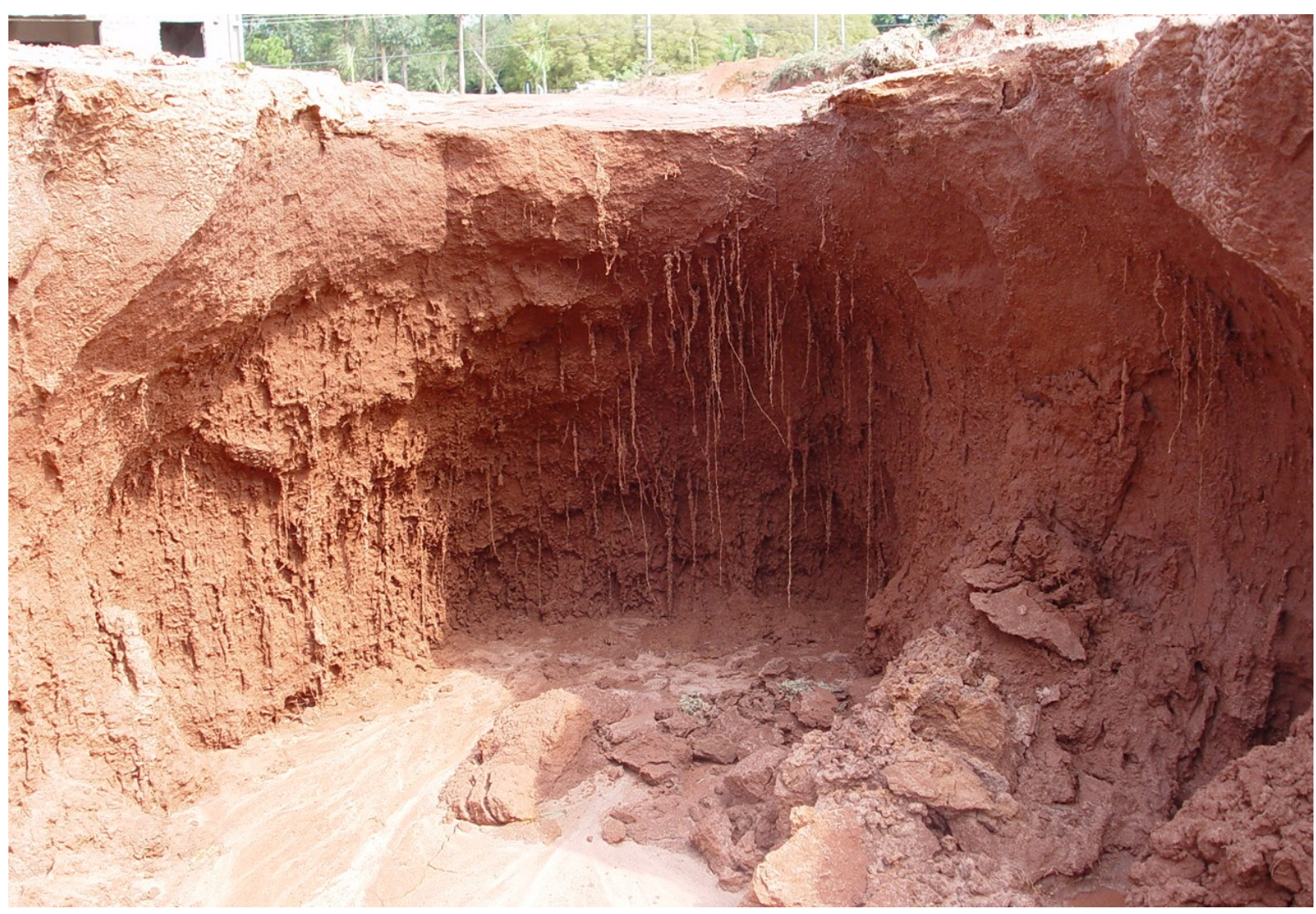

Figura 38. Outro aspecto de uma voçoroca em estágio bastante avançado com dutos no seu interior, ocasionado devido à fragilidade dos solos. Autor: STIPP, M. E. F., 2006. 


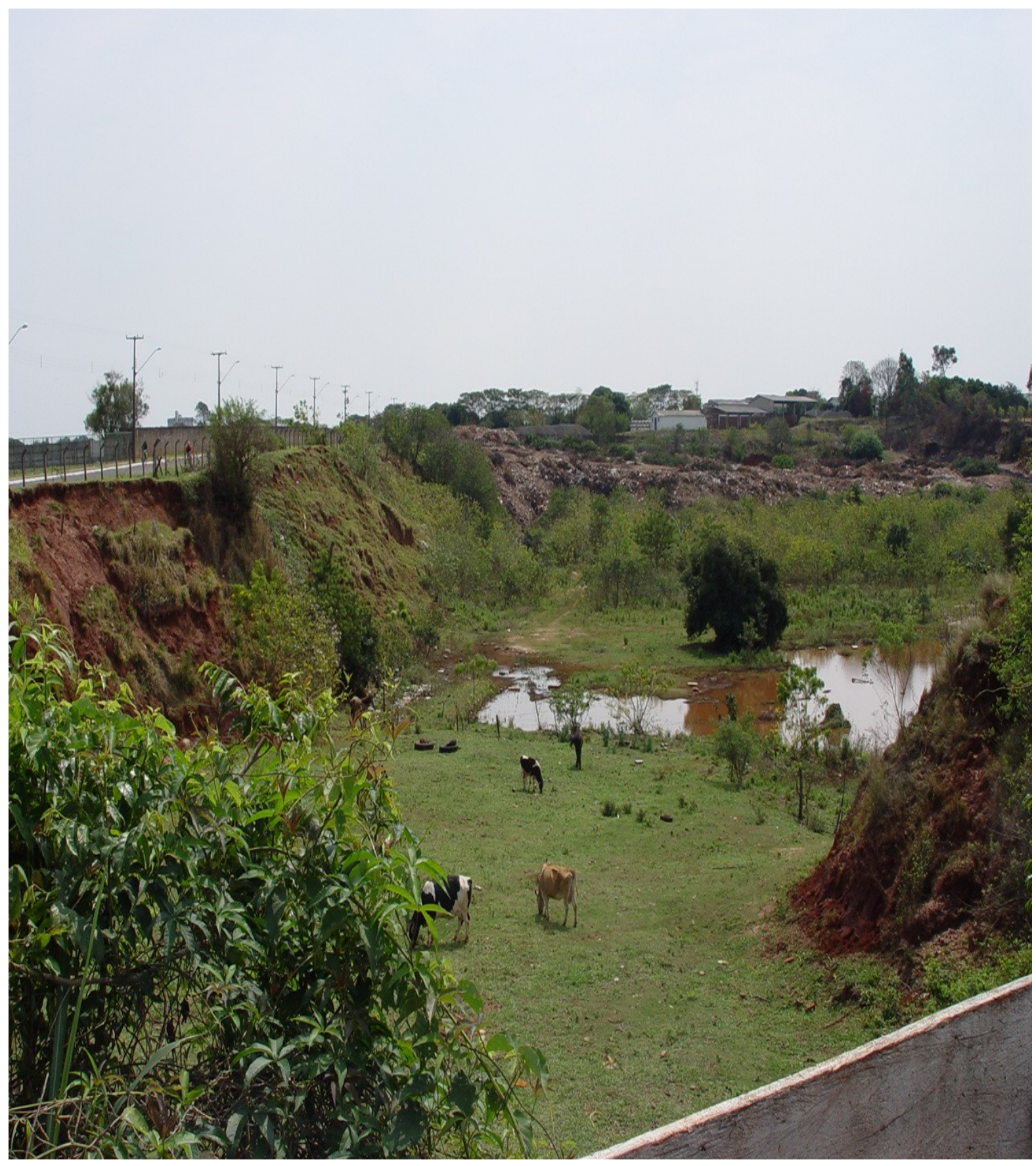

Figura 39. Aspecto da porção inferior de uma vertente onde ocorre o afloramento do lençol freático; e aspectos de degradação originados pelo pisoteio do gado. Autor: STIPP, M. E. F., 2006. 


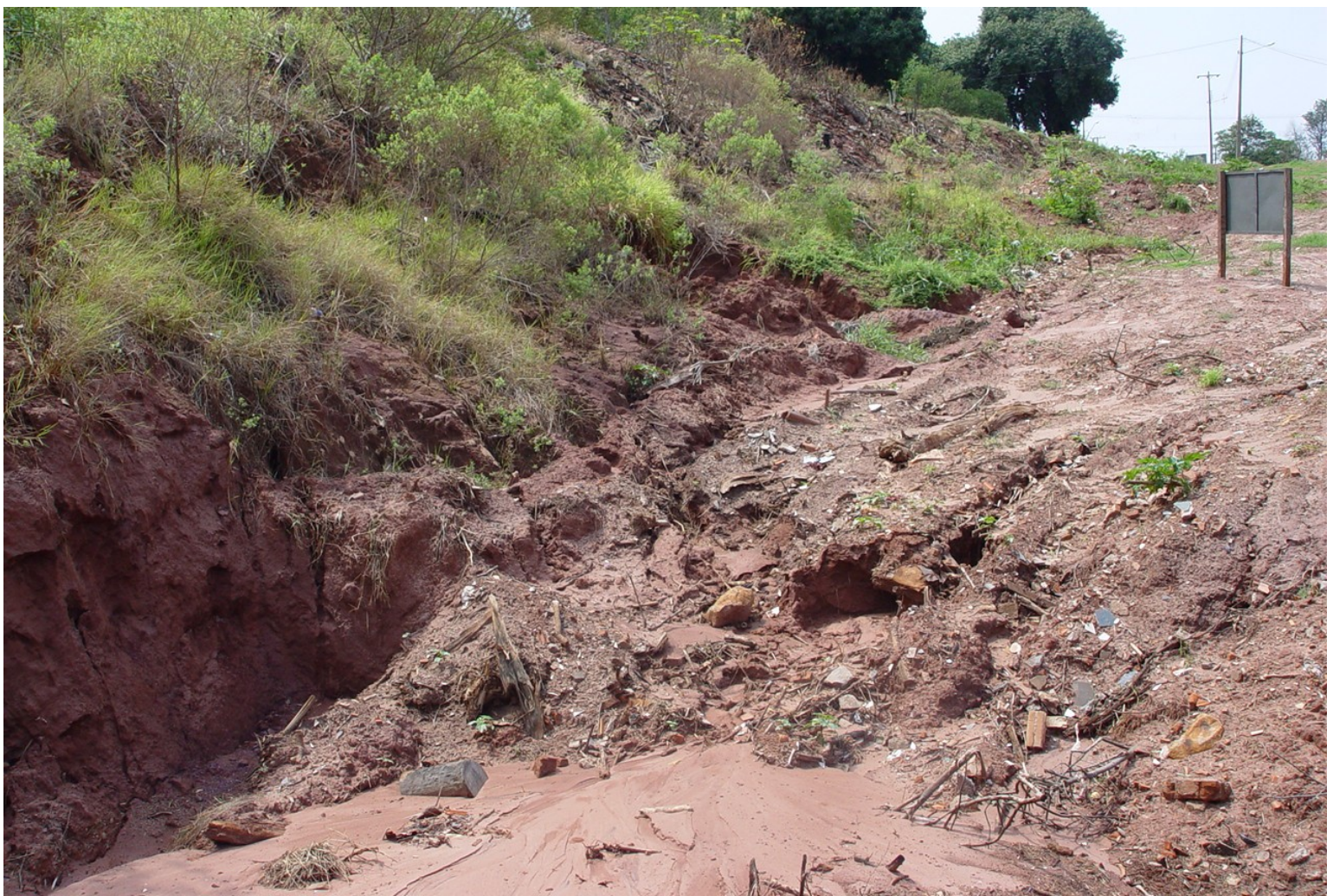

Figura 40. Aspecto da parte inferior de uma vertente onde se percebe os movimentos de massa e o carreamento de sedimentos. Autor: STIPP, M. E. F., 2006.

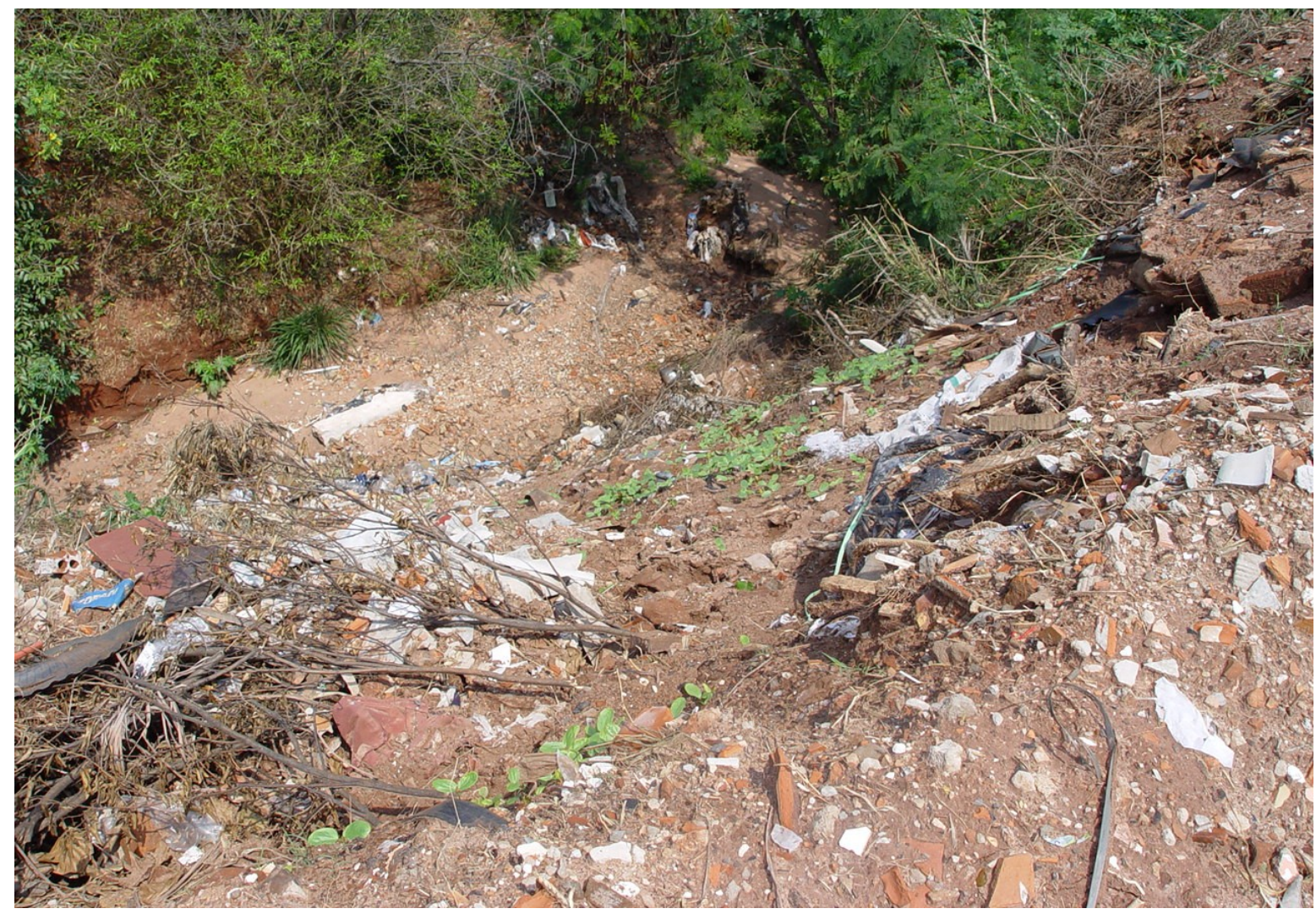

Figura 41. Aspecto da degradação promovida pela ação antrópica que se aproveita da voçoroca para depósitos de lixos domésticos. Autor: STIPP, M. E. F., 2006. 


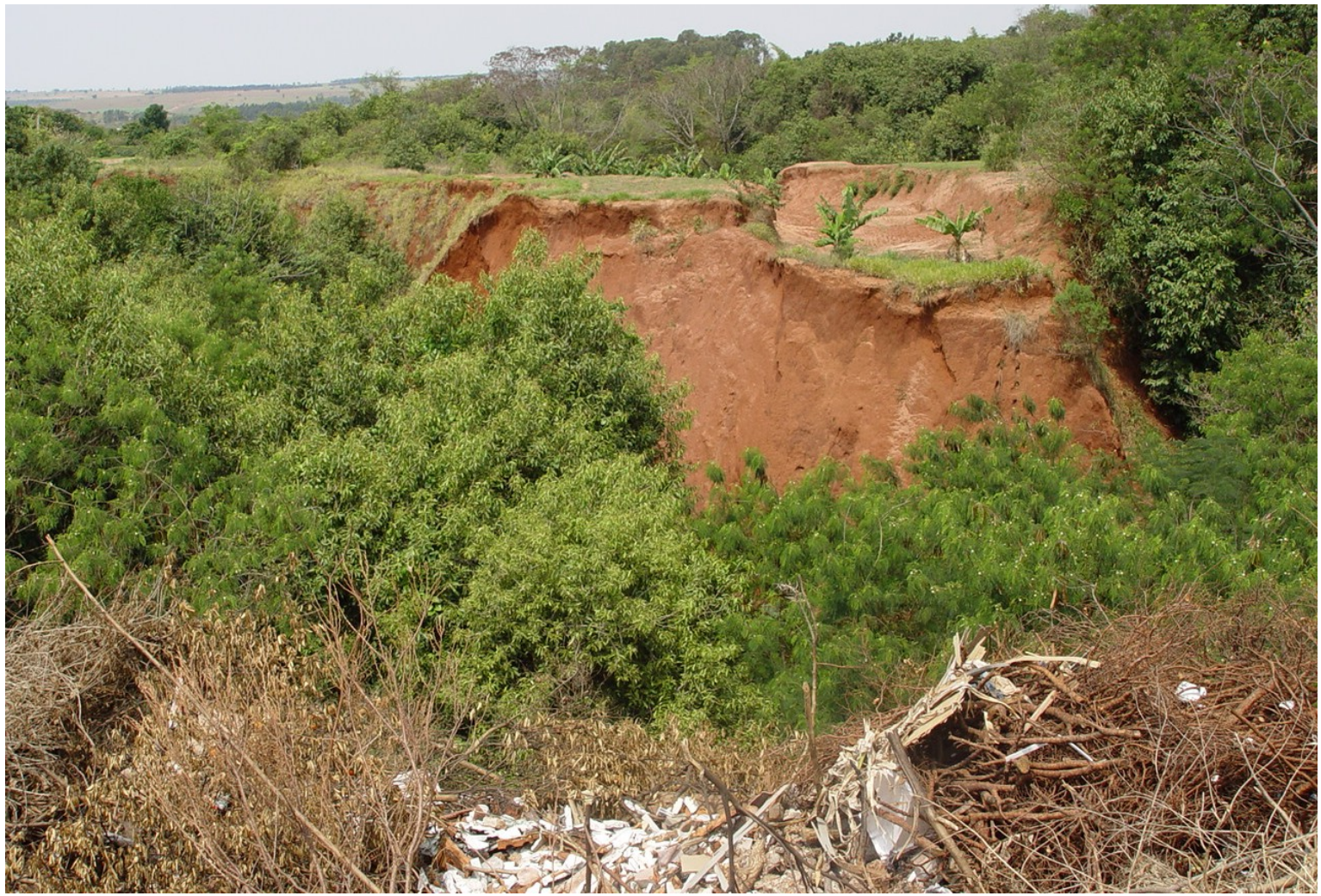

Figura 42. Desnudação do solo a partir de escorregamento de massa. Autor: STIPP, M. E. F., 2006.

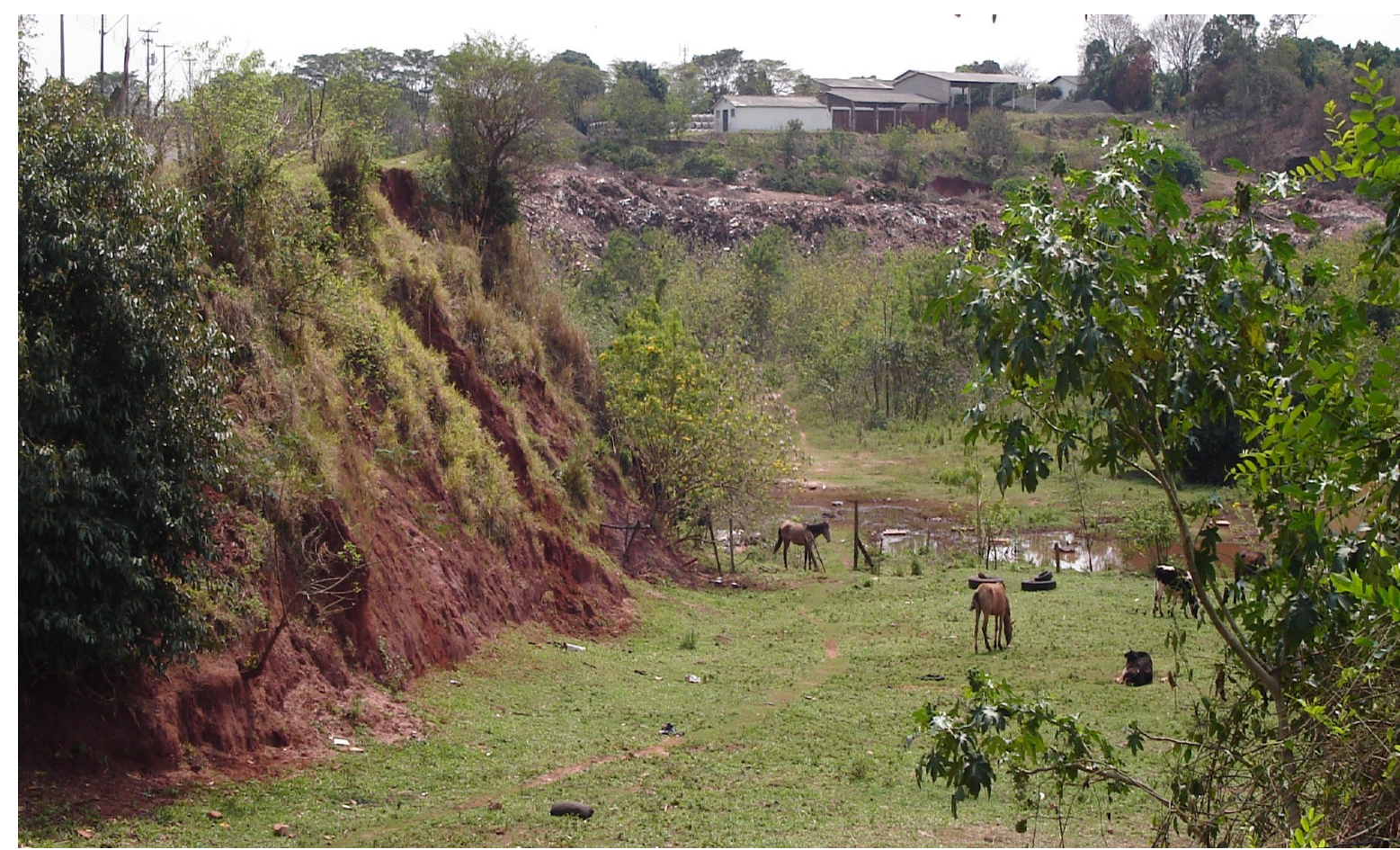

Figura 43. Aspecto da porção inferior de vertente onde aflora o lençol freático que serve de bebedouro para animais criados soltos em plena área urbana. Autor: STIPP, M. E. F., 2006. 


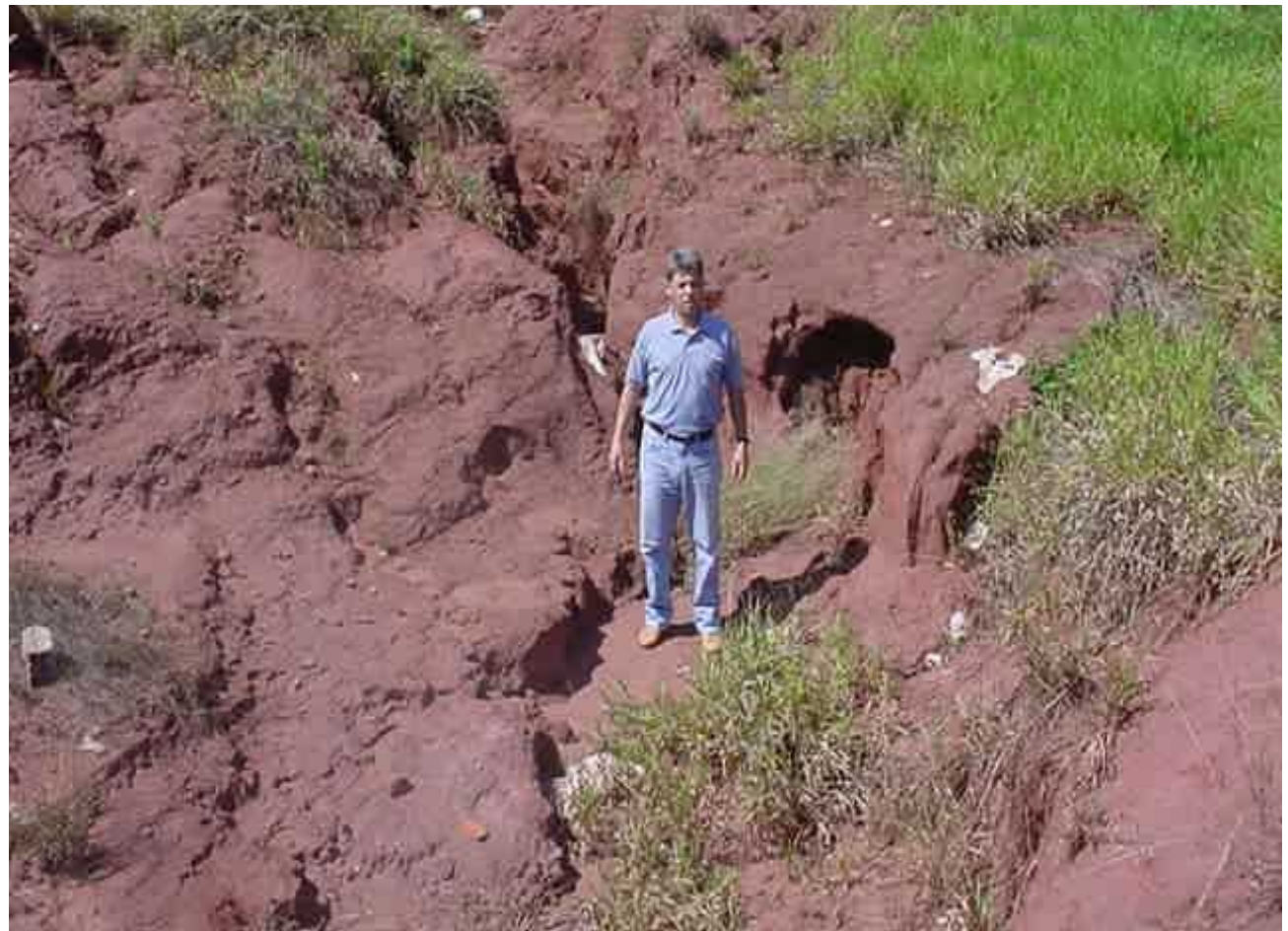

Figura 44. Manejo inadequado de solo originou a voçoroca que aparece acompanhando o sentido da declividade da vertente. Autor: STIPP, M. E. F., 2006.

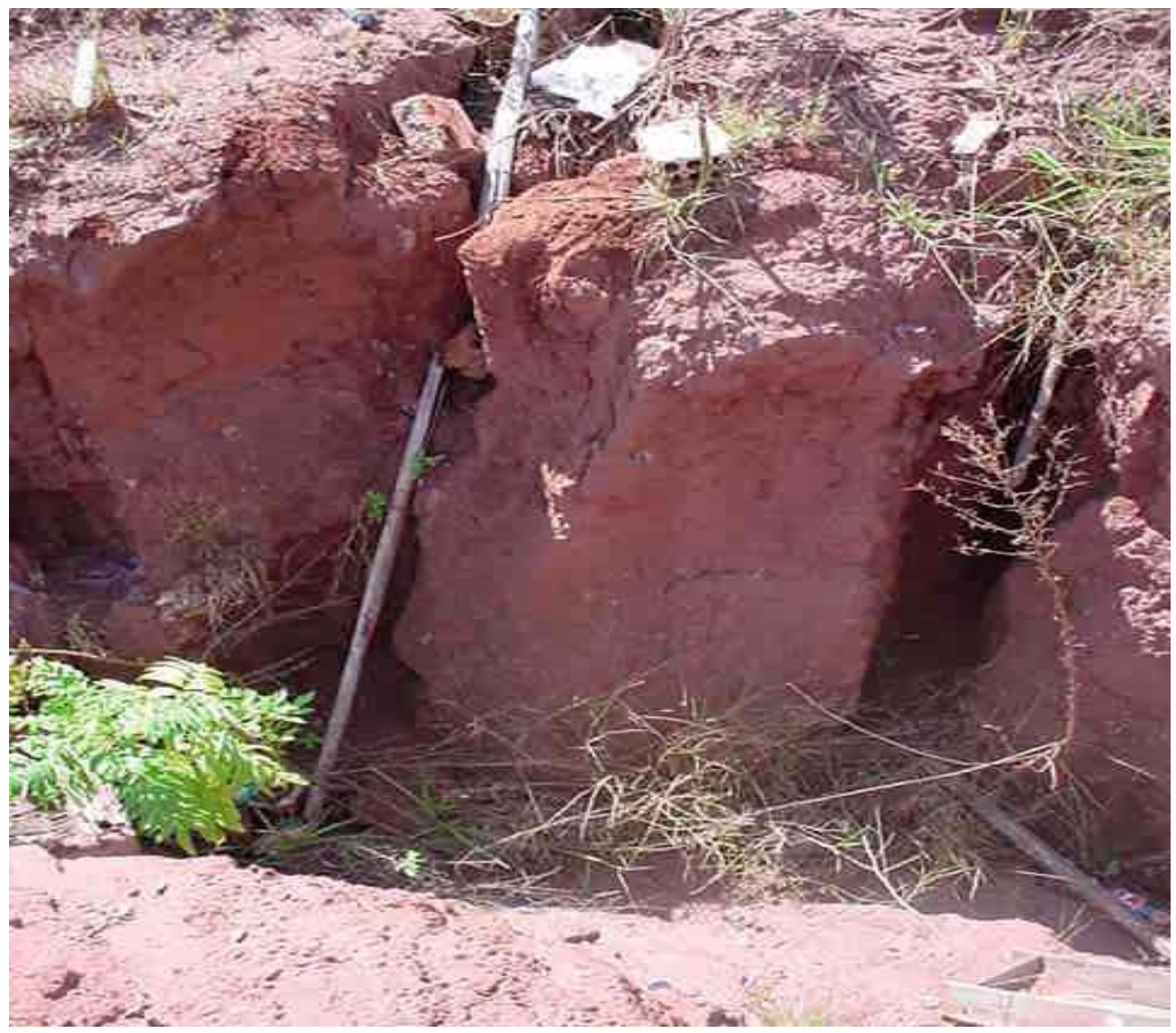

Figura 45. Um processo de envoçorocamento em plena atividade com várias ramificações, originadas pelo manejo inadequado do solo. Autor: STIPP, M. E. F., 2006. 


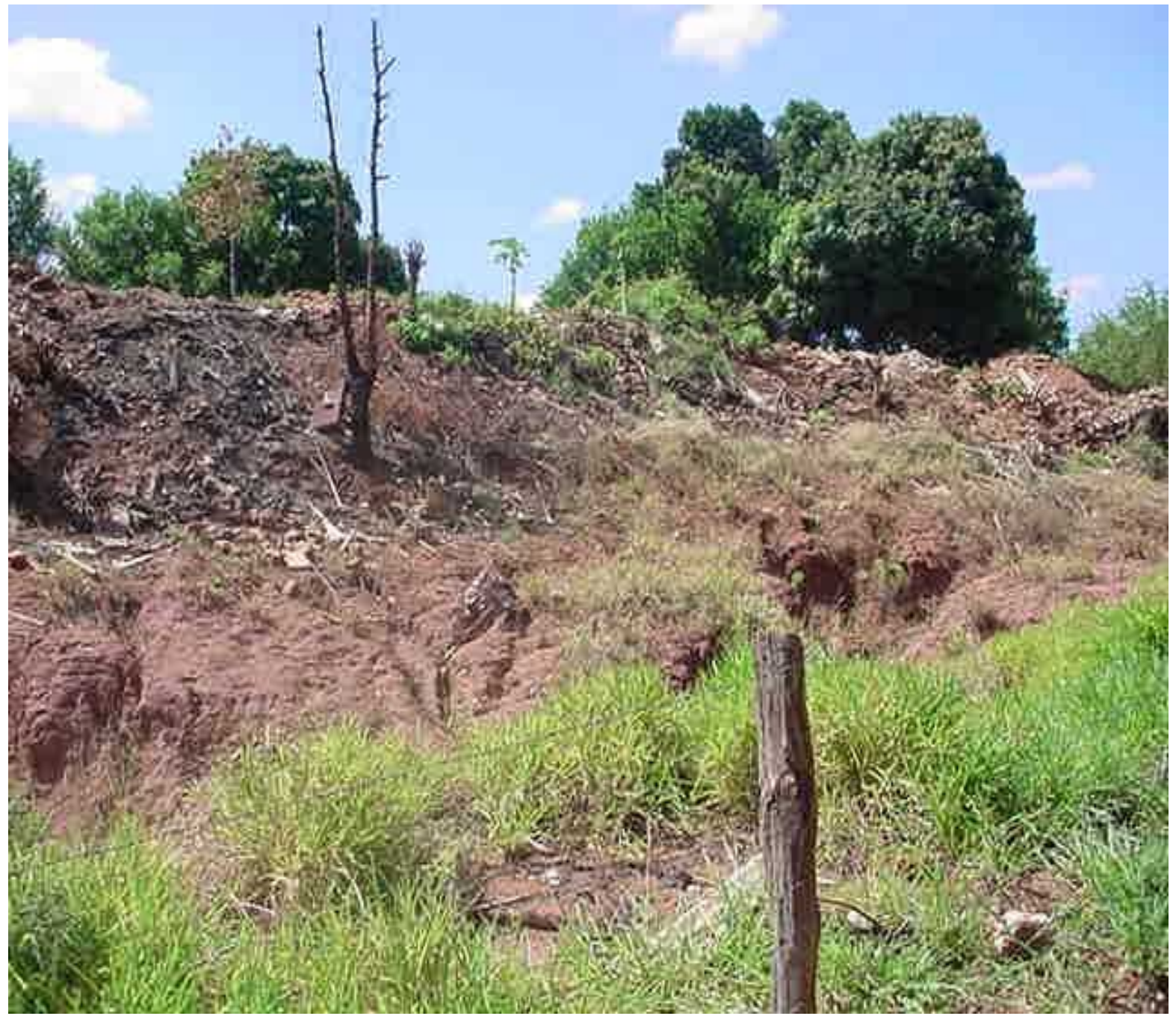

Figura 46. Aspecto geral de paisagem degradada no sítio urbano de Paranavaí. Autor: STIPP, M. E. F., 2006. 


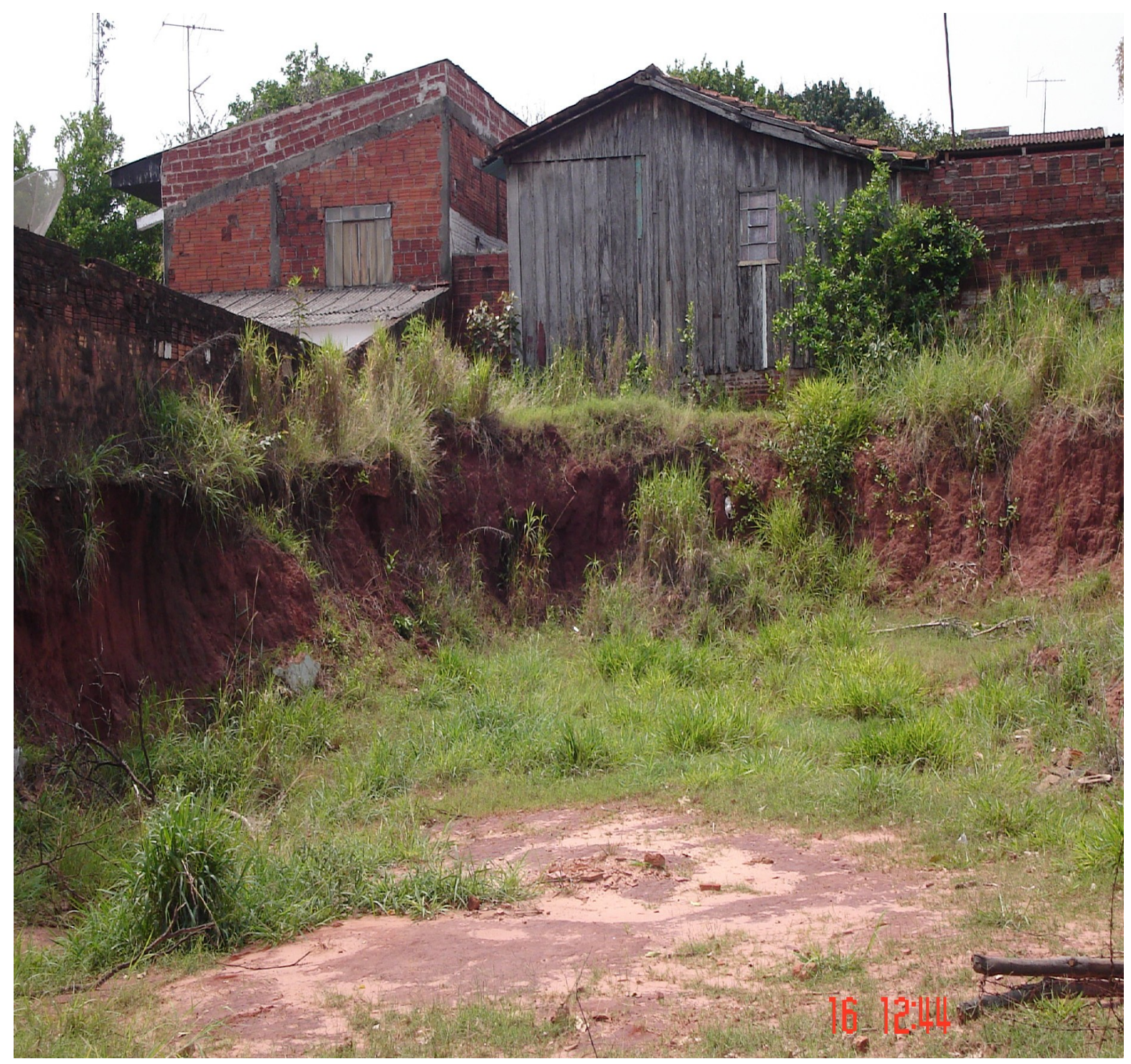

Figura 47. Aspecto da erosão de terrenos colocando em risco as habitações locais em um bairro residencial de Paranavaí. Autor: STIPP, M. E. F., 2006. 


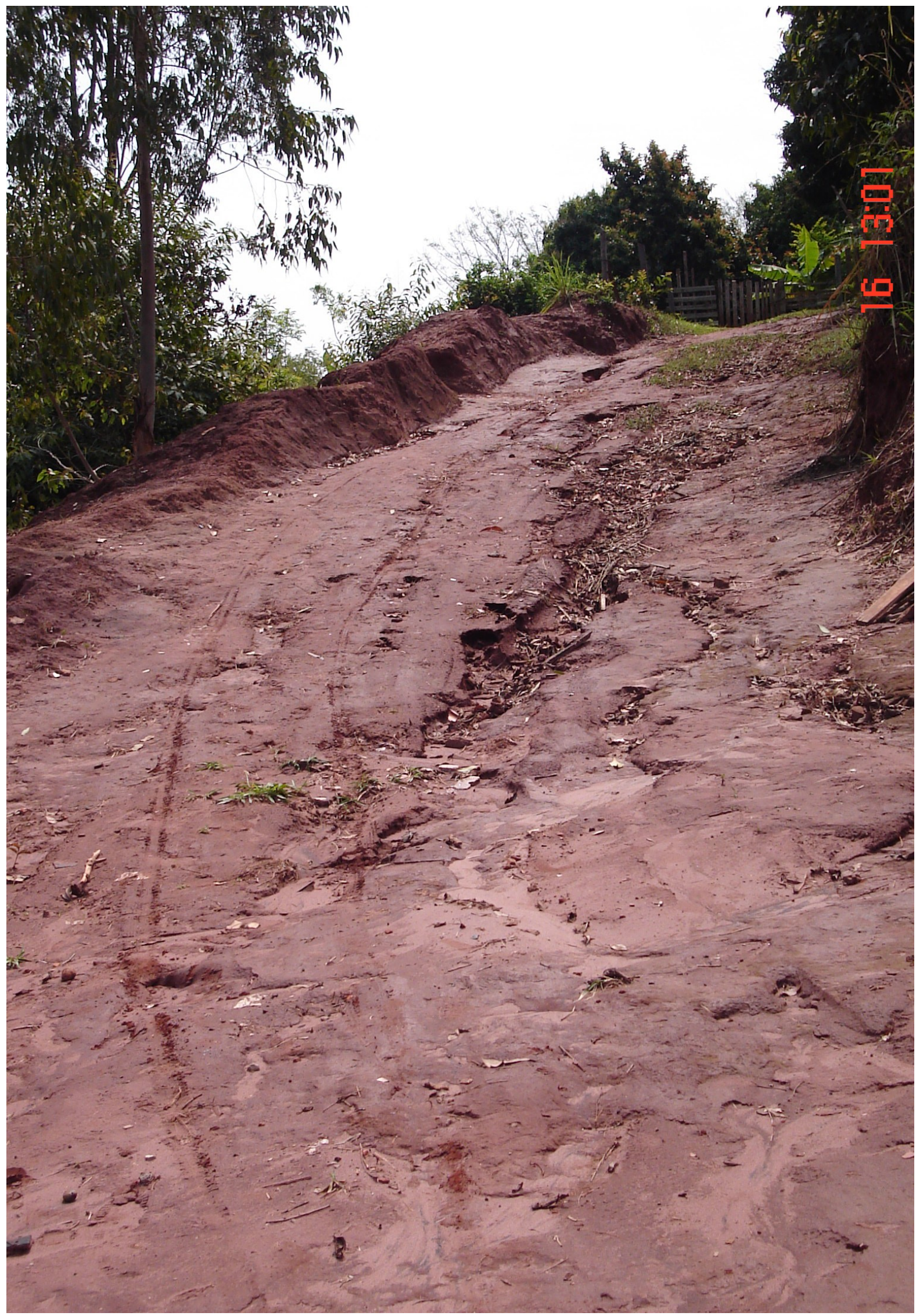

Figura 48. Erosão laminar numa vertente em cujo declive pode-se observar uma trilha de gado. Autor: STIPP, M. E. F., 2006. 
10.2 Resultados Obtidos das AnÁlises dos Pontos de Medição

Ponto 01

O Ponto 01 não apresentou carreamento do solo entre os meses novembro de 2003 até maio de 2004, fato que poderia ser explicado pela contenção de terras feita pela construção do muro de arrimo, no entanto nos meses de julho a novembro de 2004 apresentou um carreamento de $1 \mathrm{~cm}$.

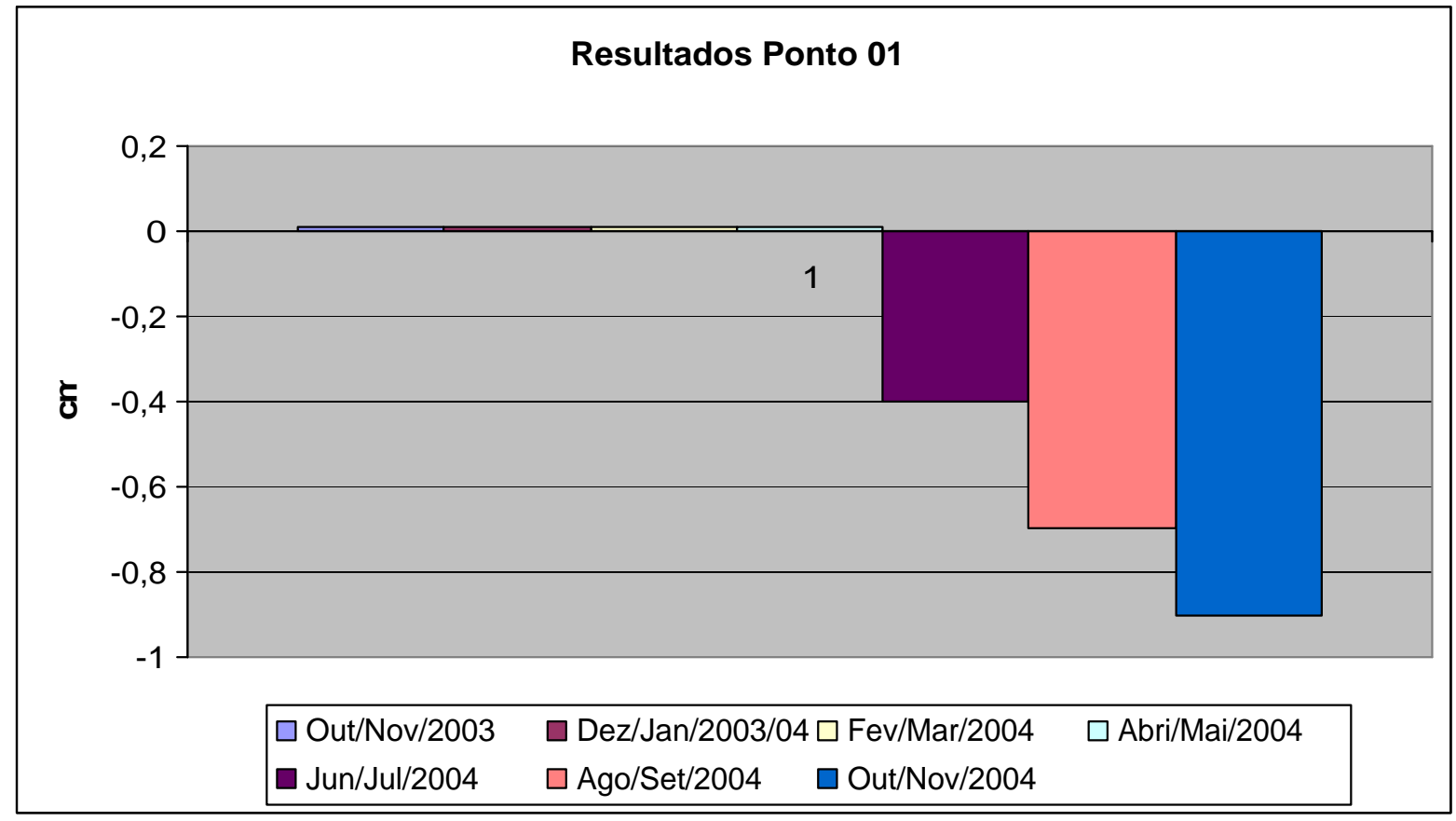

Figura 49. Gráfico de Resultados Obtidos Ponto 01. Autor: STIPP, M. E. F., 2006. 


\section{Ponto 02}

O Ponto 02 teve o carreamento mais expressivo de todos os pontos amostrados, pois nos primeiros dois meses de pesquisa já haviam sido carreados solos representados na vara por aproximadamente $10 \mathrm{~cm}$, o que não foi constante nos outros meses, quando o carreamento se deu de modo contínuo, mas sem grandes alterações como na primeira amostragem. Entre os meses de janeiro a julho o carreamento teve uma alteração pequena, sendo que nos meses seguintes ocorreu maior expressão, cerca de $2 \mathrm{~cm}$ de carreamento a cada 2 meses.

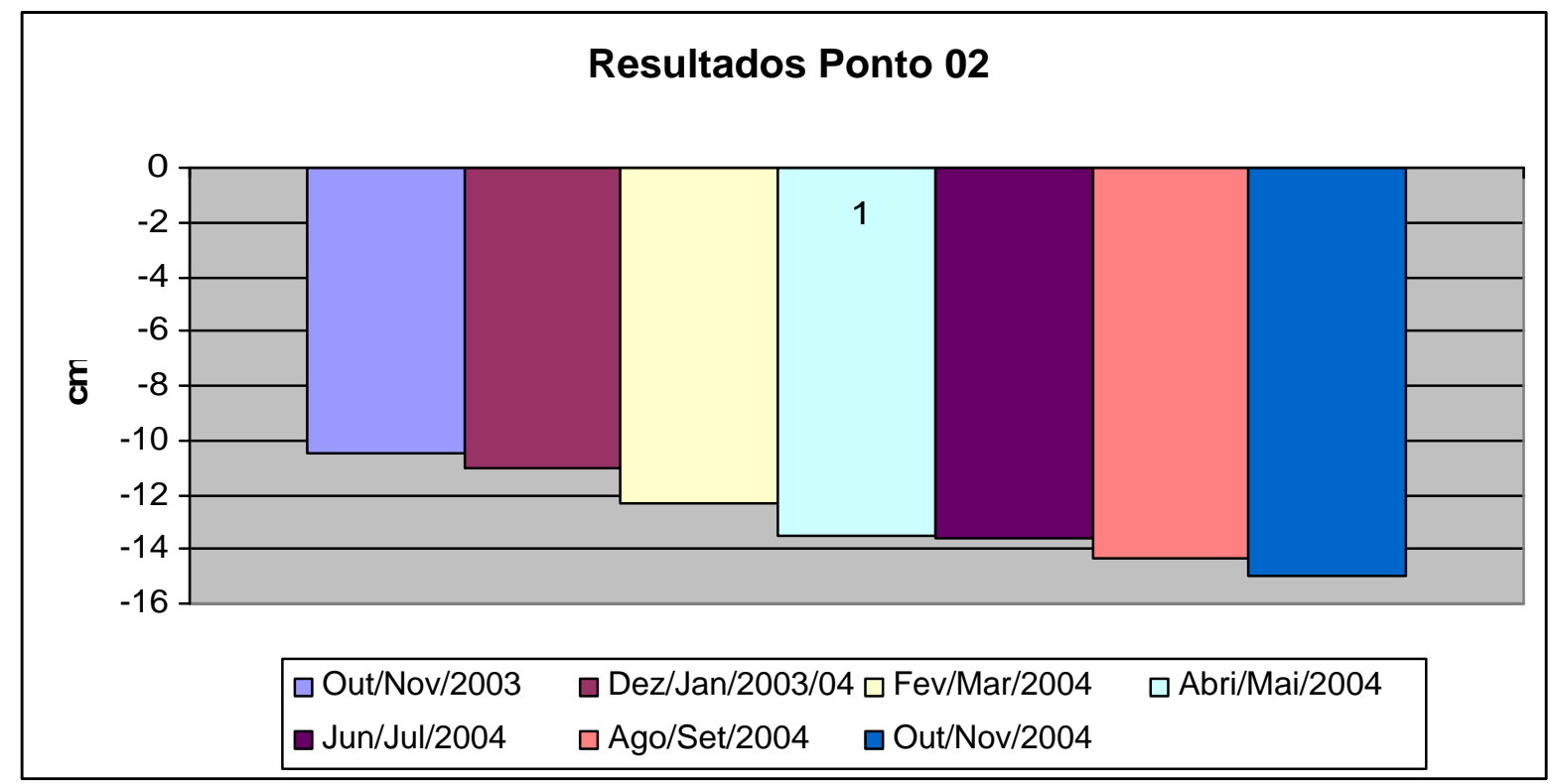

Figura 50. Gráfico de Resultados Obtidos Ponto 02. Autor: STIPP, M. E. F., 2006. 


\section{Ponto 03}

Nos primeiros meses da pesquisa, de setembro de 2003 a janeiro de 2004, o ponto 03 apresentou soterramento de solo, da ordem de $7 \mathrm{~mm}$, sendo que nos meses seguintes houve a inversão do fluxo, ocasionando o carreamento.

O mês mais marcante no ponto 3 foi no mês de maio de 2004, que até então estava sendo soterrado em cerca de $2 \mathrm{~cm}$ acima do nível de instalação do experimento, tendo uma inversão rápida e progressiva de mais $4 \mathrm{~cm}$ de carreamento até o final da pesquisa prática (campo-novembro de 2004).

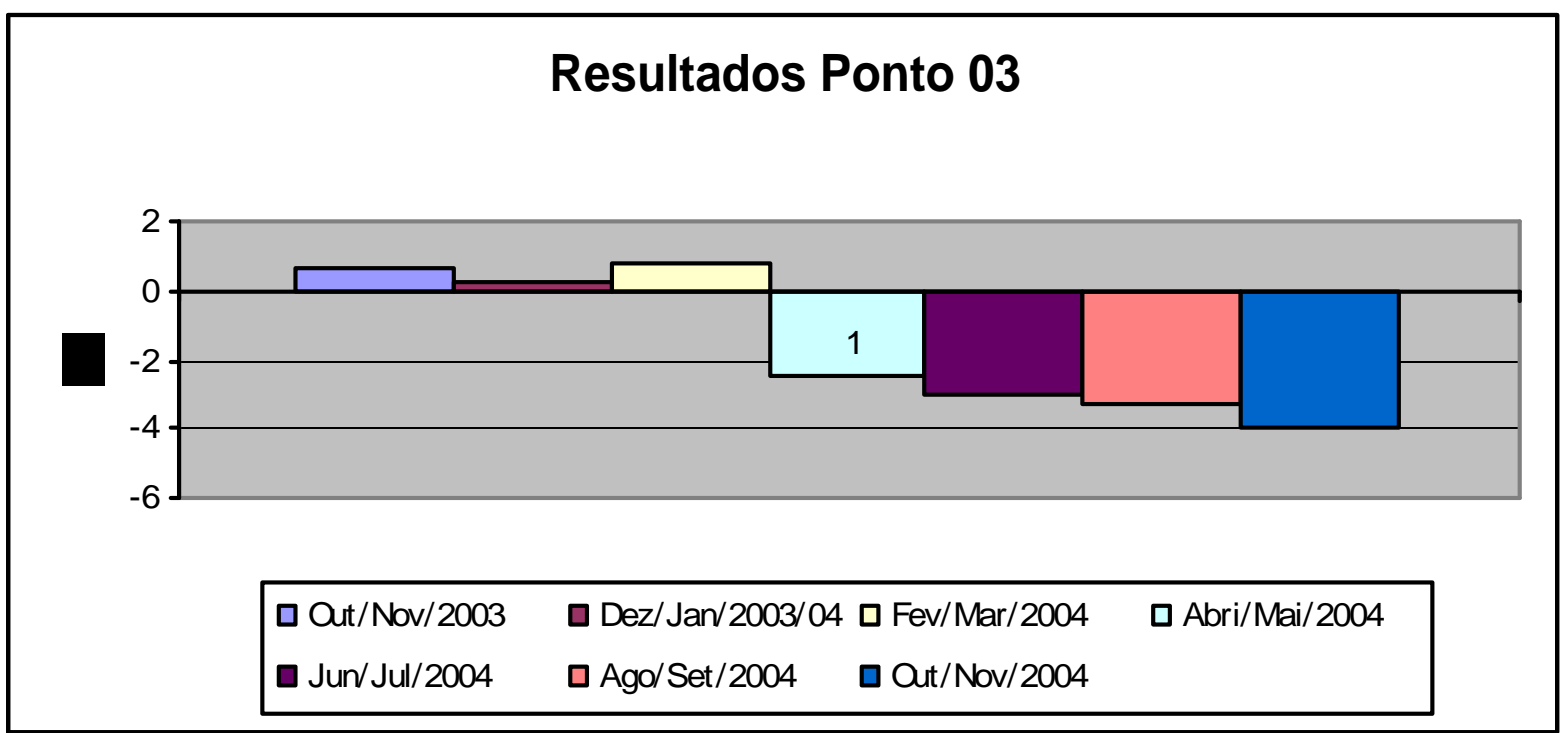

Figura 51. Gráfico de Resultados Obtidos Ponto 03. Autor: STIPP, M. E. F., 2006. 


\section{Ponto 04}

Entre setembro de 2003 a maio de 2004, o ponto 04 apresentou um carreamento de cerca de $3 \mathrm{~cm}$ aproximadamente; a partir do mês de julho de 2004 ocorreu o inverso, pois se deu um soterramento cerca de $8 \mathrm{~cm}$ a $9 \mathrm{~cm}$ até o mês de novembro de 2004 (final da pesquisa de campo), ou seja, das observações dos pontos de amostragem.

A época mais marcante dessa área foi entre o mês de maio e julho onde ocorreu o soterramento da vara em cerca de $8 \mathrm{~cm}$ invertendo o fluxo de terra que se acumulou na parte mais alta do declive.

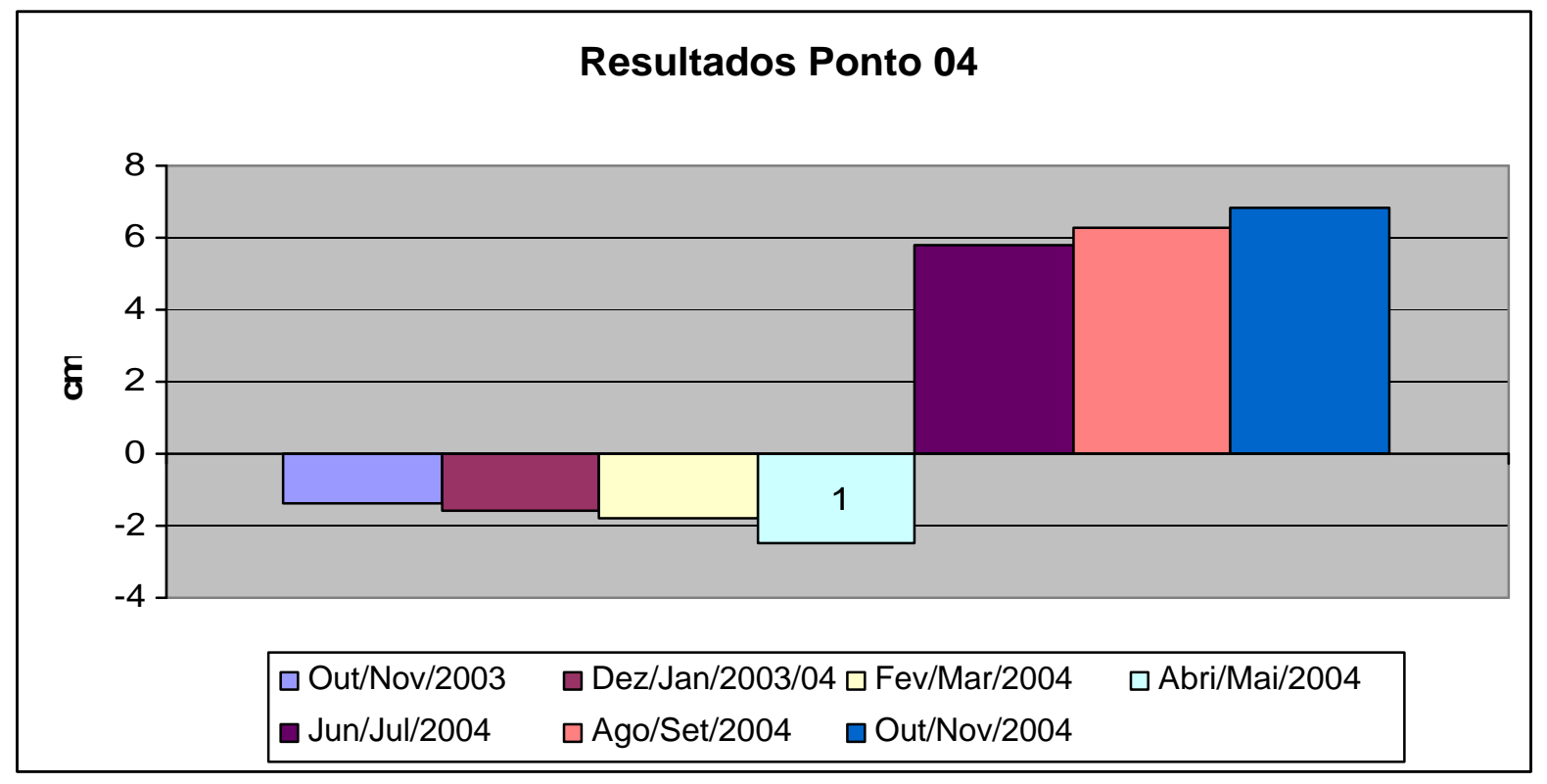

Figura 52. Gráfico de Resultados Obtidos Ponto 04. Autor: STIPP, M. E. F., 2006. 


\section{Ponto 05}

Nos primeiros seis meses da pesquisa (30/09/03 - 31/03/04), este ponto apresentou um soterramento gradativo de cerca de $2 \mathrm{~cm}$. No intervalo de 31/03/04 a 31/05/04 e 31/07/04 a 30/09/04, ocorreu um carreamento de solo, de cerca de $3 \mathrm{~mm}$ e $5 \mathrm{~mm}$ respectivamente, voltando ao estágio inicial, após 30/09/04 com o soterramento de cerca de $1 \mathrm{~cm}$. O fato mais marcante ocorreu nesses dois intervalos quando houve uma inversão de fluxo de terra na área, apesar de ser de poucos $\mathrm{mm}$, foi bastante expressivo na análise dos dados.

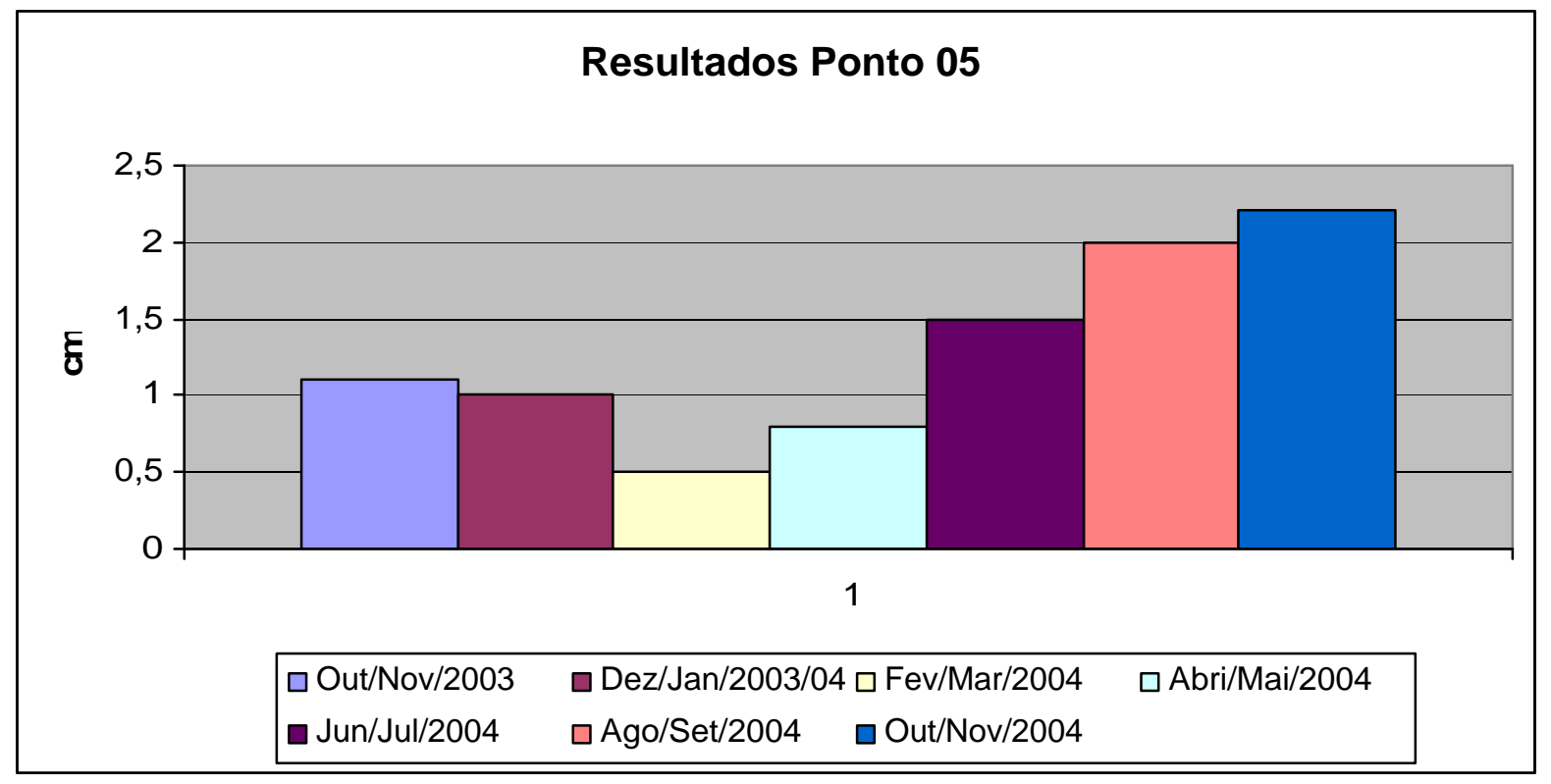

Figura 53. Gráfico de Resultados Obtidos Ponto 05. Autor: STIPP, M. E. F., 2006. 


\subsection{Resultados da Análise da Evolução dos Elementos Climáticos DuRante o PERÍODO dO EXPERIMENTO}

\subsubsection{Precipitação}

Como um dos principais causadores do processo de carreamento do solo (lixiviação) está relacionado com a quantidade de pluviosidade, procurou-se analisar o padrão de chuvas no período de dois anos (2003 e 2004), para se entender o mecanismo e as similaridades climáticas predominantes na área.

Procedeu-se uma análise através das tabelas dos dados meteorológicos fornecidas pelo IAPAR (Instituto Agronômico do Paraná) e dos dados coletados pelos pluviômetros instalados na cidade.

Comparando-se os dados obtidos no IAPAR com os dados coletados nos pluviômetros manuais, instalados para esta pesquisa, deparou-se com as mesmas informações, o que pode ser explicado pelo porte urbano de Paranavaí (cidade de pequeno a médio porte), isto é, que não apresenta grande extensão urbana. Foram semelhantes os índices de pluviosidade nos pontos em que se alocou os pluviômetros, por isso foram descartados.

O Gráfico (Figura 54) demonstra o padrão normal do clima da região noroeste do Paraná, Cfb (Koppen), com a característica de verão chuvoso e inverno seco e aumento gradativo da pluviosidade de agosto até setembro, com queda nos meses de outubro e novembro, voltando a atingir maior pluviosidade no mês de dezembro, precipitação característica da estação chuvosa da área. 


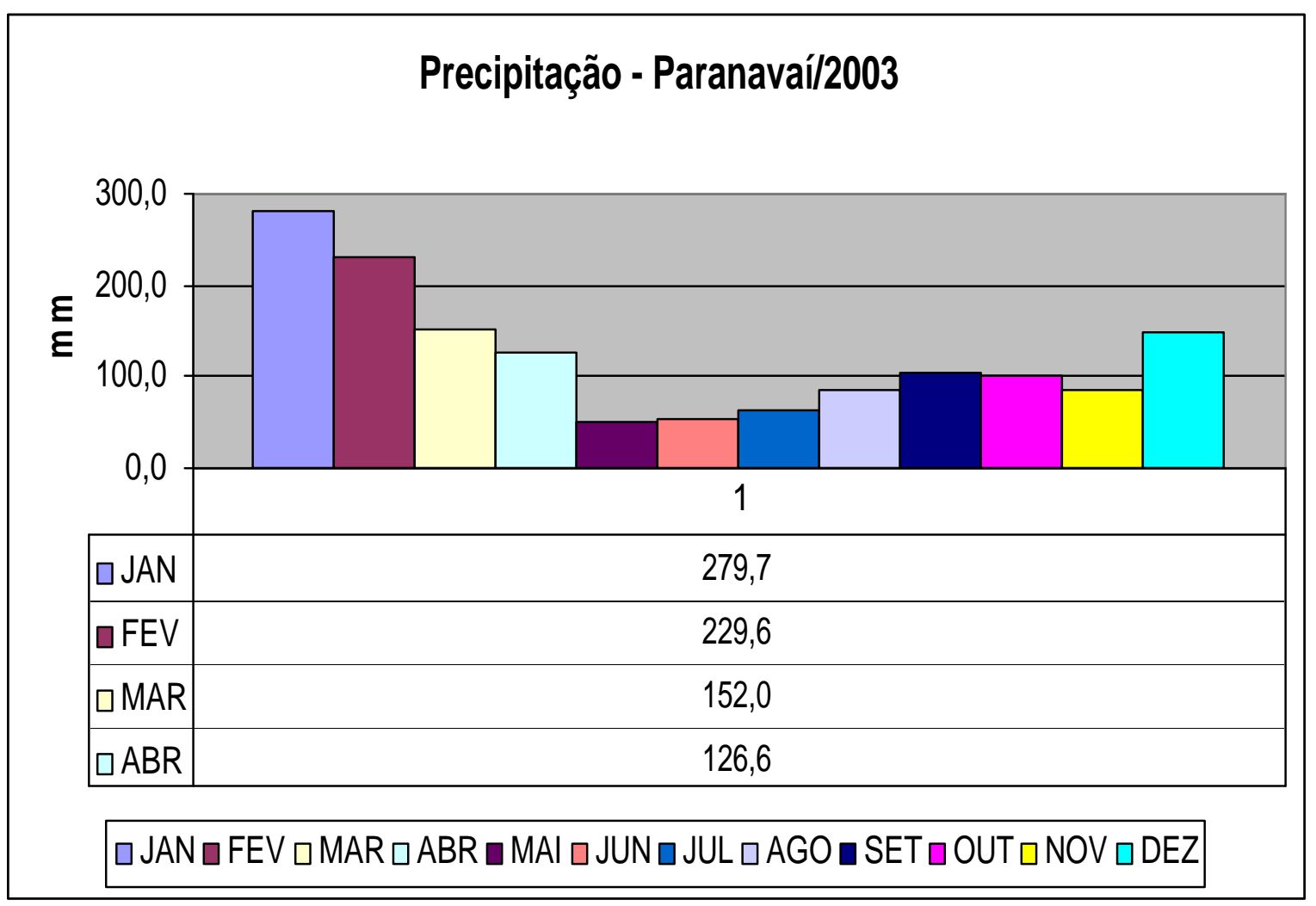

Figura 54. Gráfico de Precipitação Paranavaí/2003. Fonte: IAPAR, 2006.

Pode-se concluir que a pluviosidade no ano de 2003 se concentrou no verão e na primavera, caracterizando-se como um ano com poucas chuvas em torno de $1477,2 \mathrm{~mm} / \mathrm{ano}$.

Já em 2004 apresentou uma alteração de padrão normal, como se pode constatar na tabela abaixo.

A média de chuva aqui foi em torno de $1.596 \mathrm{~mm}$, maior que no ano anterior.

Ao se analisar o gráfico da precipitação observou-se uma alteração no padrão pluviométrico da área (Figura 55). 


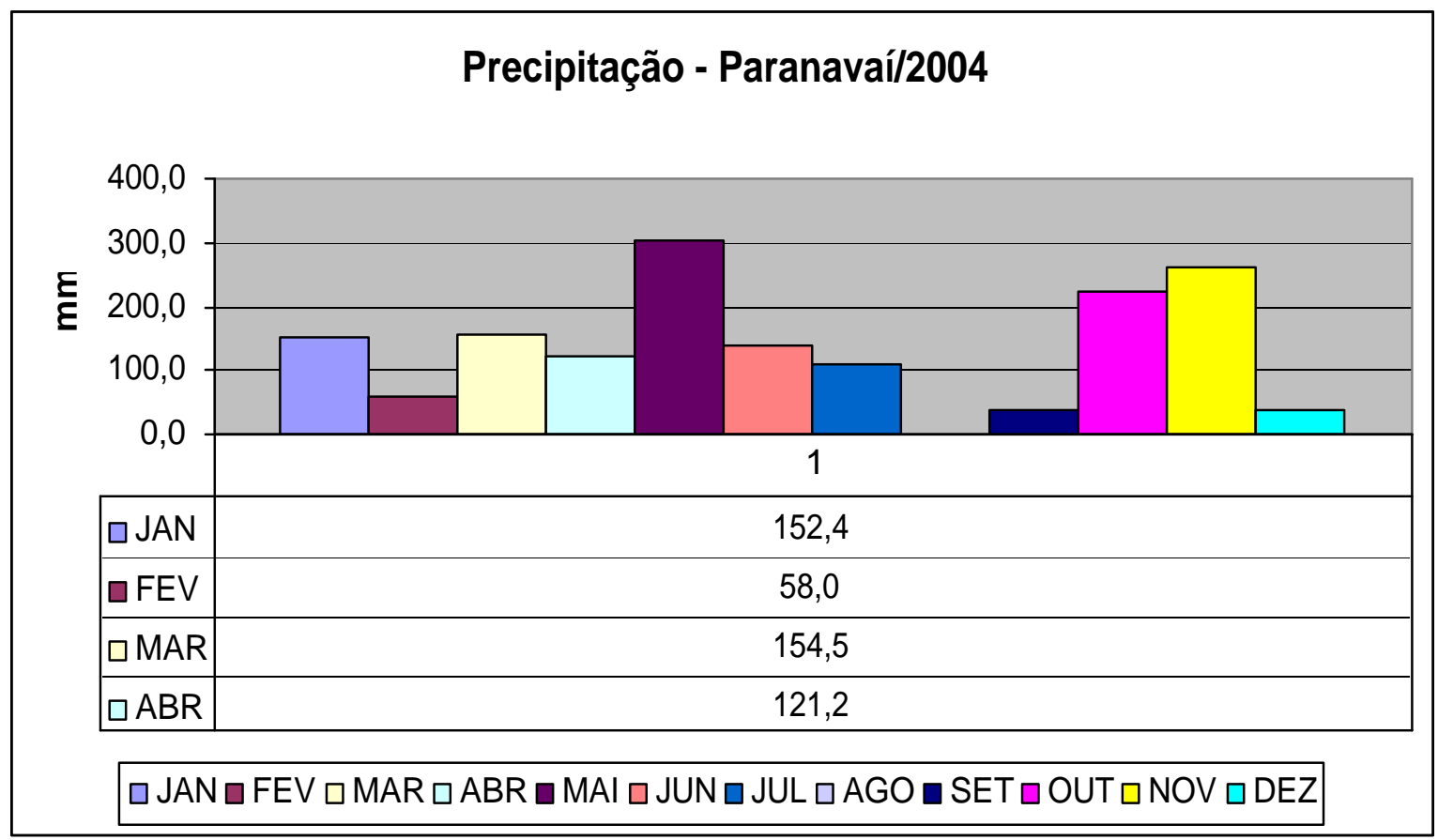

Figura 55. Gráfico de Precipitação Paranavaí/2004. Fonte: IAPAR, 2006.

A pluviosidade permaneceu constante durante todo o ano, mas sua maior concentração se deu no período de maio, outubro e novembro. Períodos esses que corresponderam ao outono e primavera respectivamente, com ausência quase total de chuva no mês de agosto.

\subsubsection{Temperatura}

Foram analisadas as temperaturas anuais conjuntamente, verificando-se que não houve nenhuma alteração expressiva entre 2003 e 2004.

Com a análise dos dados de precipitação e temperatura nos anos de 2003 e 2004, pode-se verificar que houve pouca expressividade no contexto para a análise de acordo com os objetivos em estudo.As temperaturas não sofreram grande alteração de um ano para o outro.

A única alteração expressiva foi a queda da temperatura no período de maio e junho dos dois anos (2003 e 2004), com alteração na máxima, o que pode significar grande umidade relativa no período, e confrontando com a pluviosidade, 
veio confirmar que o mês de maio de 2004, se caracterizou por apresentar grande pluviosidade e baixa amplitude térmica, decorrente provavelmente de uma frente fria atípica na região (Figura 56 e 57).

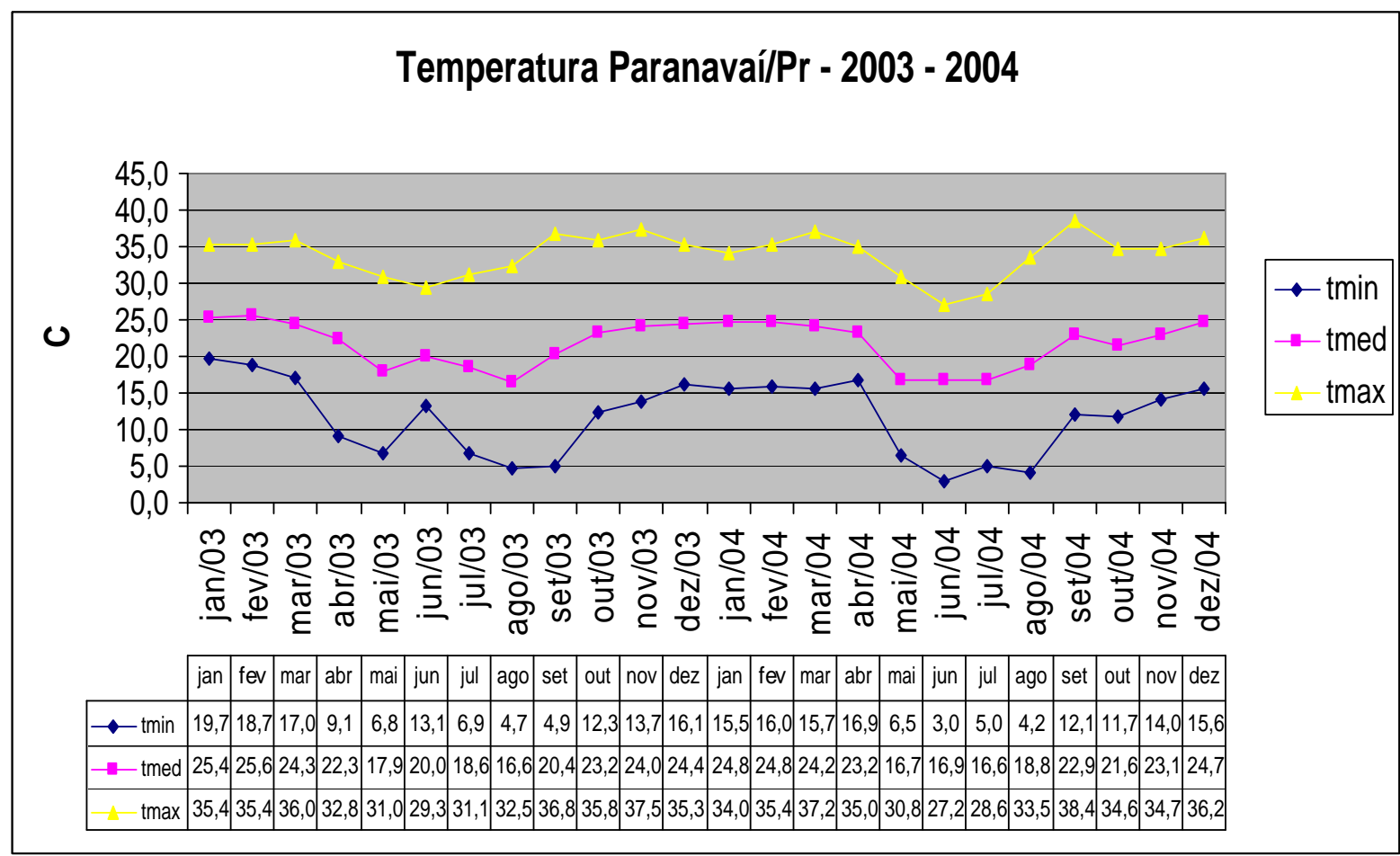

Figura 56. Gráfico da Temperatura da área urbana de Paranavaí - 2003 e 2004. Fonte: IAPAR, 2006.

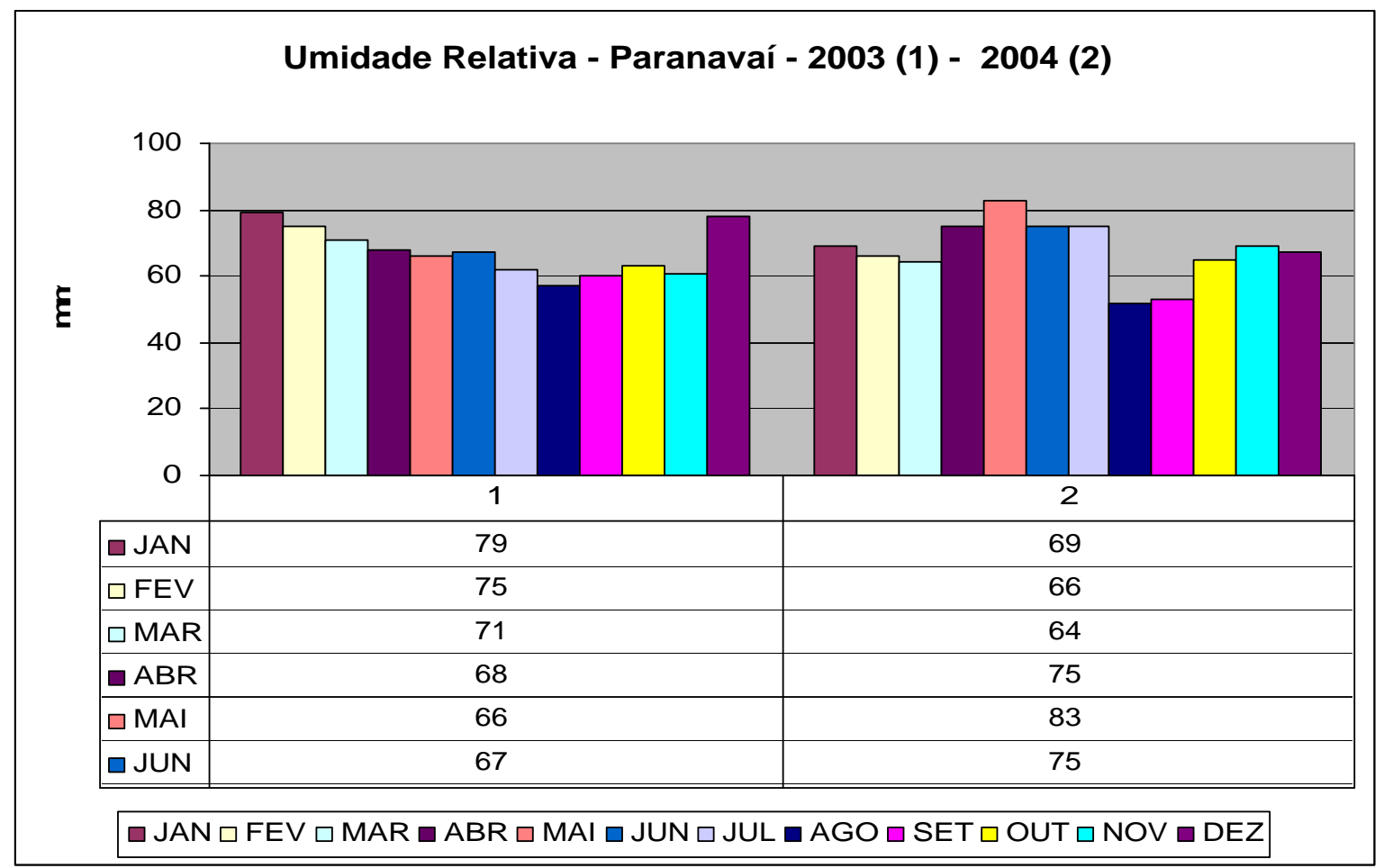

Figura 57. Gráfico da Umidade Relativa Paranavaí - 2003/2004. Fonte: IAPAR, 2006. 
A partir dos dados coletados em campo, como a pesquisa se concentrou a cada dois meses, perfazendo um ano de observação dos experimentos, optou-se por analisar a pluviosidade a partir do somatório de dois em dois meses, para se obter um resultado equivalente à quantidade real de chuva que cada ponto sofreu. Esse valor foi convertido em $\mathrm{cm}$.

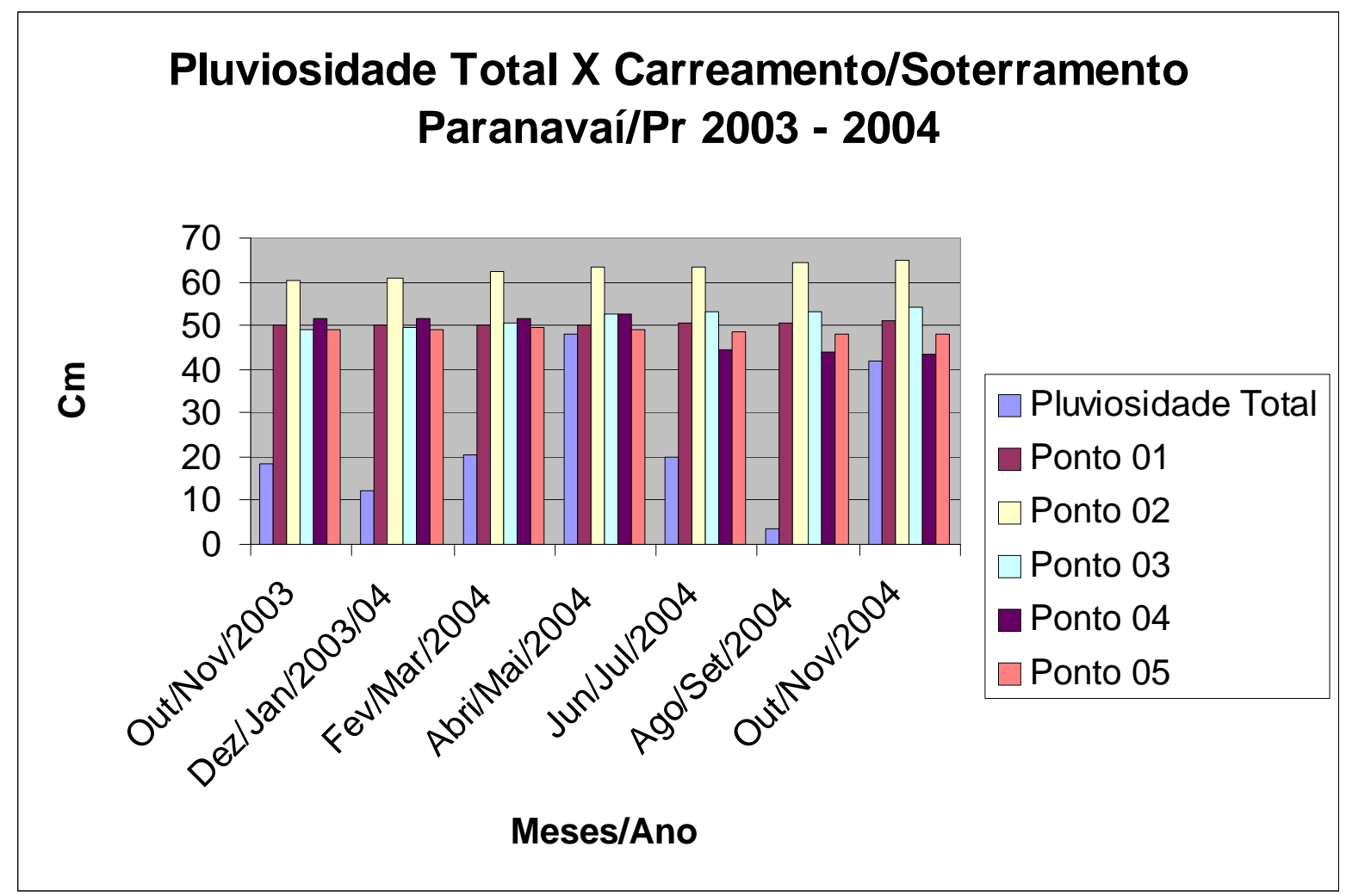

Figura 58. Gráfico de Pluviosidade Total (somatória 2 em 2 meses) x Dados Coletados nas Varas de Medição. Fonte: IAPAR, 2006.

A partir do gráfico, pode-se afirmar que a pluviosidade não foi a responsável pelo carreamento/soterramento do solo nos pontos aferidos, como demonstravam os dados do Plano Diretor do Município de Paranavaí, do ano de 2001, portanto, houve a necessidade de se averiguar outro fator climático eminente no processo da arenização que predomina na região, ou seja, a ação do vento. 


\subsubsection{Vento}

O vento como fator inerente ao processo de arenização, uma das hipóteses deste estudo, parece ser o maior responsável pelo processo que atinge a área, pois, mesmo em condições climáticas de ausência de precipitação - estiagem - o processo se mostrou contínuo dentro do padrão de movimentação da terra deslocada, na área de estudo.

Por isso se fez necessário o estudo dos ventos na região, bem como a confecção da Carta de Direção e Velocidade dos Ventos proposta por Cunha (1988) estudada por Mendonça (1994) e Stipp (2001), para se proceder uma análise mais acurada.

\subsection{Resultados da Análise dos Ventos}

\subsubsection{Ventos Regionais}

O estado do Paraná, segundo Wagner (1989) tem predomínio dos ventos de NE (Nordeste) - E (Leste) - SE (Sudeste). Este fato está relacionado com os centros de alta pressão do Atlântico e do Pacífico, que originam ventos nessa direção.

Segundo Wagner (1989), nos dias que antecedem a entrada de frentes frias na área, os ventos sopram de direção preferencial SW (Sudoeste); se concentrando nas direções $S W-W-S-N W$, tal fato evidencia uma correlação entre a entrada de massas polares, que são acompanhadas de ventos do quadrante sul, e as ocorrências de picos máximos extremos.Estes estão ligados à forte intensidade dos ventos na massa de ar frio em frentes frias de deslocamento rápido, bem como a forte intensidade convectiva que pode ocorrer na linha de instabilidade frontal. 


\subsubsection{Ventos em Paranavaí}

A cidade de Paranavaí, segundo a velocidade do pico máximo,apresenta-se com o valor médio máximo de $19 \mathrm{~m} / \mathrm{s}-1$ e com vários picos médios de $16 \mathrm{~m} / \mathrm{s}-1$. Dentre as variações mensais pode-se afirmar, que há uma tendência de concentração de maiores valores nos meses de primavera e verão e de menores valores de outono e inverno nos anos de 2003 e 2004 - como pode se observar nos gráficos abaixo onde LI - Limite Inferior -LS - Limite Superior - M Média.

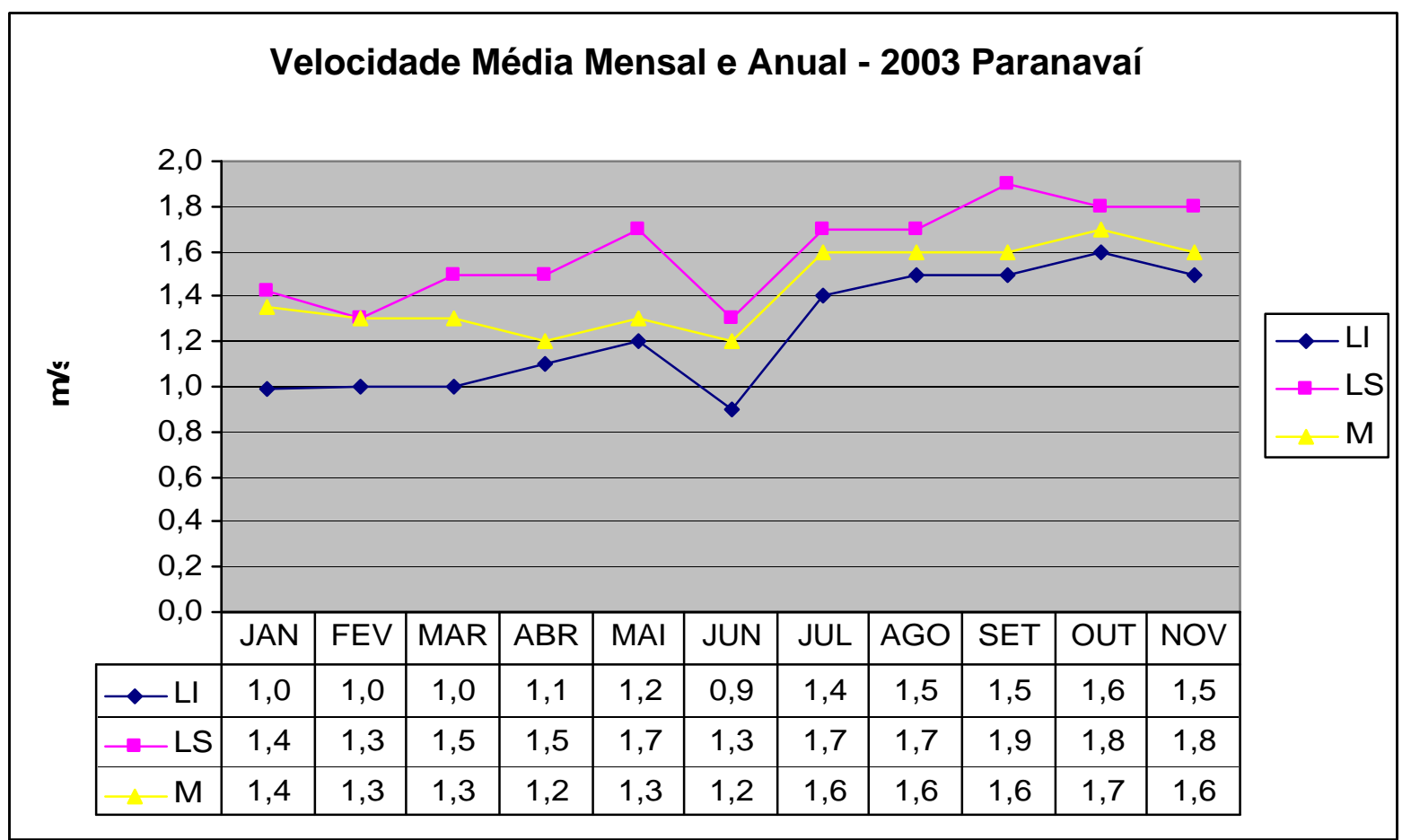

Figura 59. Gráfico de Ventos Paranavaí - 2003. Fonte: IAPAR 2006. 


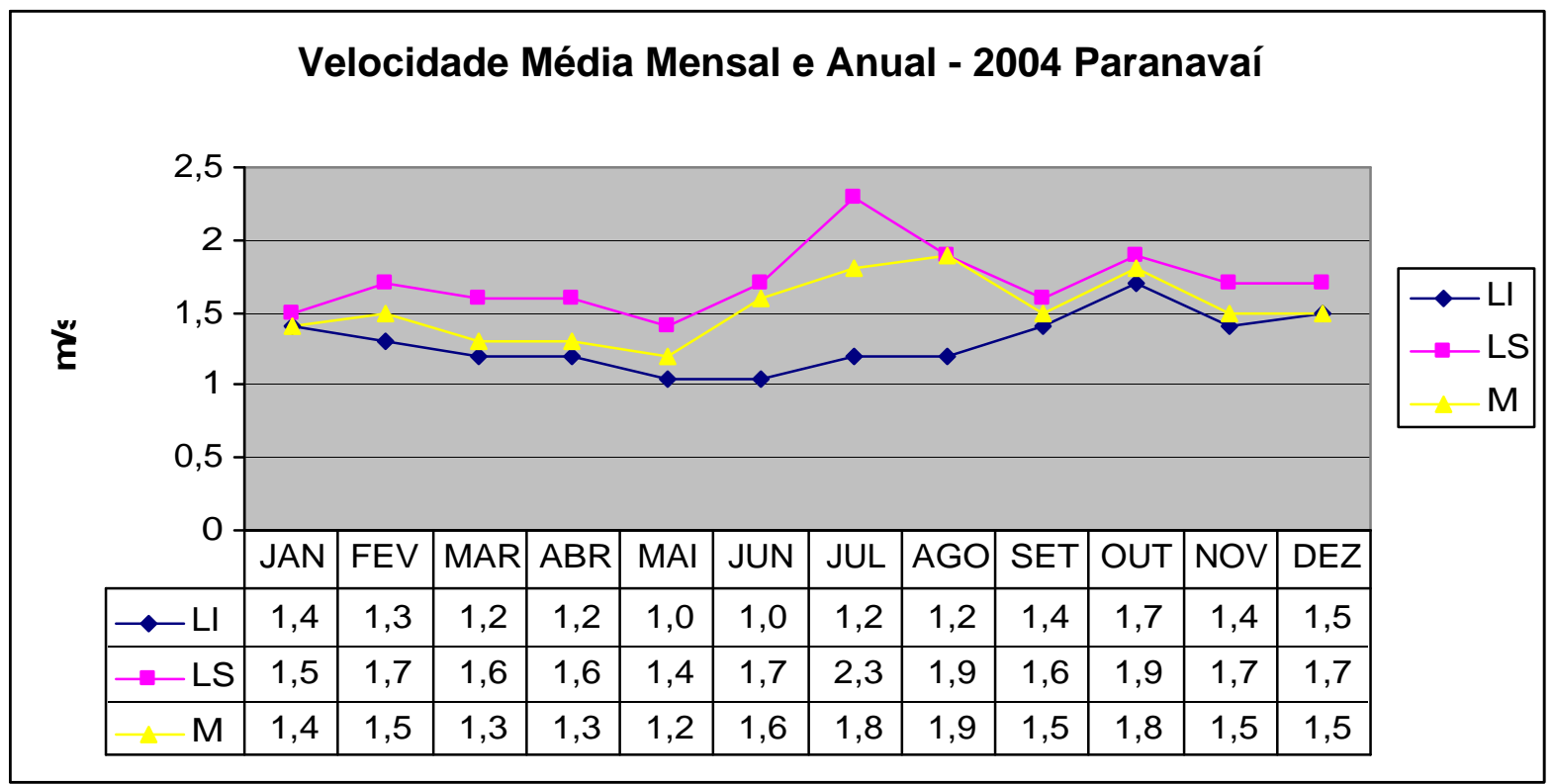

Figura 60. Gráfico de Ventos Paranavaí - 2003. Fonte: IAPAR 2006.

Analisando o fenômeno da arenização através do fator climático vento, nos anos de 2003 e 2004, observou-se que os ventos, no período de outono e inverno que precederam à entrada de Frentes Frias, chegaram a alcançar altas velocidades, o que acarretou o carreamento dos sedimentos.

\section{Carta de Direção e Velocidade dos Ventos de Superfície}

A representação da Carta de Direção e Velocidade dos Ventos foi proposta por Cunha, K.B. (1988), com base na proposta de geógrafos soviéticos, representando uma área de dimensão regional. A mesma proposta foi aplicada a um estudo de escala local em Londrina por Mendonça (1992).

Para a elaboração da Carta de Direção e Velocidade dos Ventos de Superfície, adotou-se como metodologia primeiramente a identificação dos divisores de água e foram isolados os topos de relevo utilizando-se a Carta Hipsométrica, e demarcadas as direções das faces das vertentes na Carta de Orientação de Vertentes, em seguida, estas faces foram divididas em alta, média e baixa vertentes. Essa divisão foi feita subtraindo-se a cota de maior valor da de menor valor, dividindo o resultado por três, obtendo-se assim, os três níveis de cada vertente. 
Determinou-se então as seguintes cores para as velocidades dos ventos:

- Vermelho - Velocidade Alta (Topos);

- Laranja - Velocidade Média (Alta Vertente);

- Amarelo Escuro - Velocidade Baixa (Média Vertente);

- Amarelo Claro - Calmaria (Baixa Vertente)

- Branco - Fundos de Vale.

Para determinar a direção dos ventos, baseou-se na disposição do relevo, observando a influência dos vales na canalização dos ventos, pois, nos topos e nas altas vertentes os ventos correm mais livremente, enquanto nas médias e baixas os ventos são influenciados pelo relevo.

Delimitou-se micro-bacias segundo a rede de drenagem e, com base na direção destas, foram identificadas as direções dos ventos.

A análise da Carta de Direção e Velocidade dos Ventos de Superfície permitiu concluir que os locais de medição na área urbana de Paranavaí situam-se nas áreas apontadas como sujeitas a ventos de média e alta velocidade.

A partir dessa Carta de Direção e Velocidade dos Ventos, pode-se concluir que a dinâmica do ar na superfície exerceu influência direta na ação de carreamento/soterramento sofrido pelas varas de medição. Portanto a área de Paranavaí, devido ao desmatamento em seu entorno, possui ventos constantes, como se pode comprovar no capítulo dos ventos regional e local. O vento foi fator determinante para a atividade de movimentação desse material, tornando-se um importante agente no processo de arenização, mesmo em condições de pouca precipitação. 


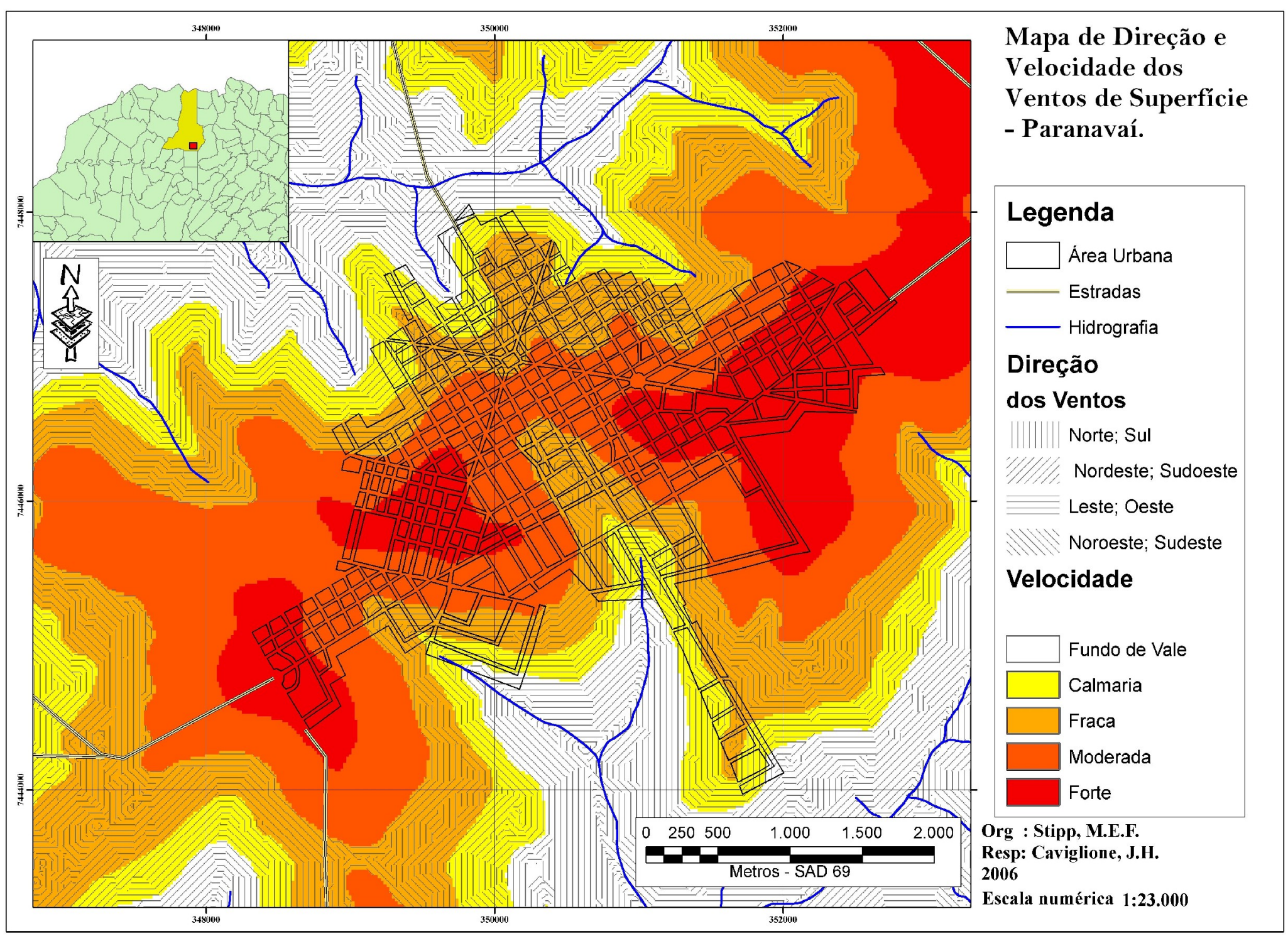

Figura 61. Carta de Direção e Velocidade dos Ventos de Superfície. Paranavaí - 2006. 


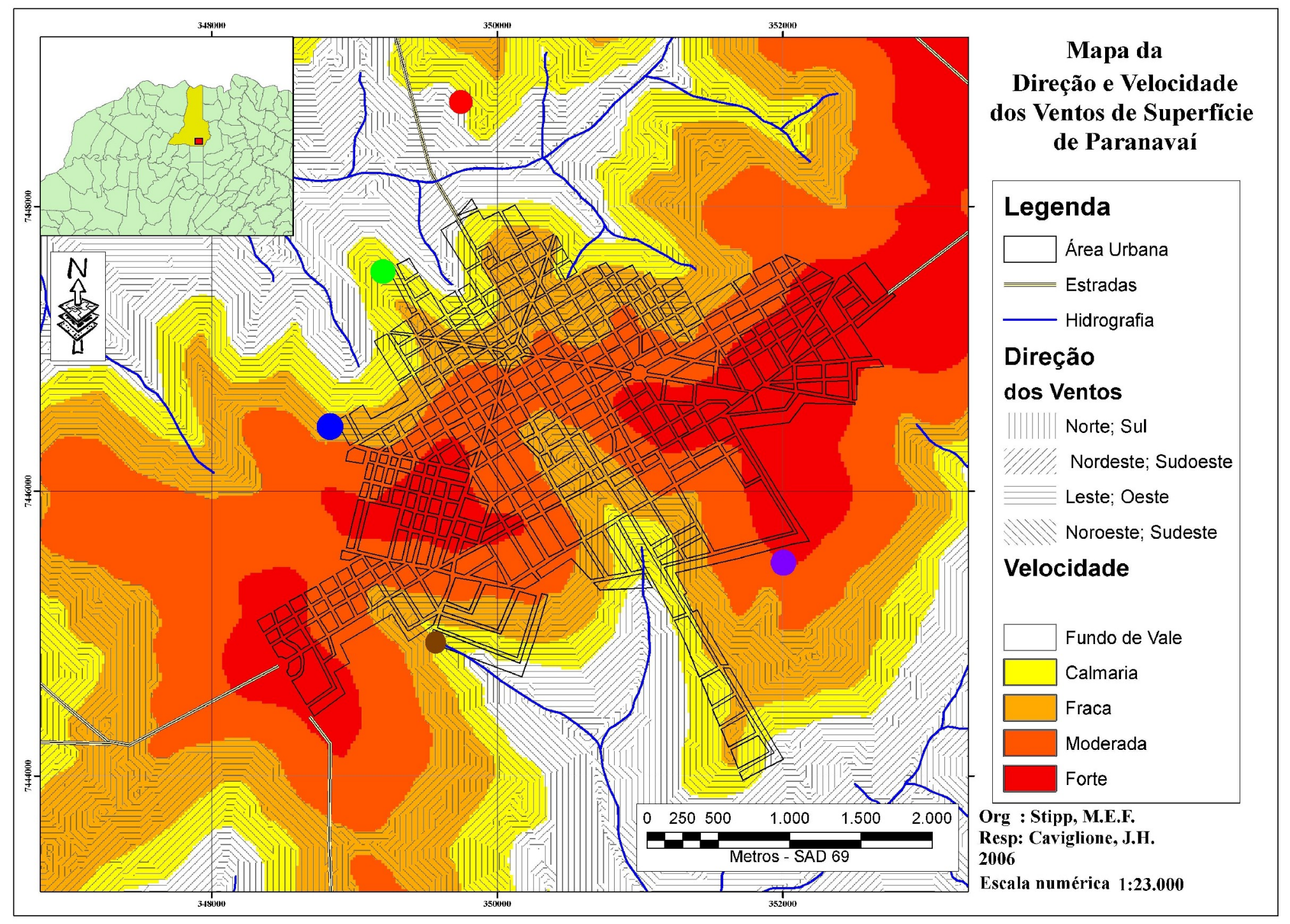

Figura 62. Carta de Direção e Velocidade dos Ventos de Superfície com a localização das áreas de riscos apontadas neste estudo. Paranavaí - 2006. 
A partir desta sobreposição pode-se constatar que os pontos de medição em sua maioria estão localizados na parte de ventos fracos a fortes. Com exceção do ponto 1 - representado em vermelho - que está localizado na parte de fundo de vale - calmaria, o que explica o processo de carreamento ter ocorrido somente no período do inverno, quando se dá a mudança de direção dos ventos da região, que são preferencialmente de Nordeste e passam a ser de Sudoeste - Sul.

Nos outros pontos permanece constante 0 processo de carreamento/soterramento, que também pode ser explicado a partir da Carta de Direção e Velocidade dos Ventos, pois, os mesmos estão sujeitos a ventos constantes, devido principalmente à falta de vegetação, que é o principal fator que poderia amenizar esse impacto.

Como análise final desta pesquisa, utilizou-se da classificação de Declividades de Ross (1990), procurando-se identificar cada ponto aferido de acordo com as tabelas abaixo, levando-se em conta os diversos mapas confeccionados e os trabalhos de campo realizados no local, para se estabelecer uma melhor classificação.

\begin{tabular}{|c|c|}
\hline CATEGORIAS & $\%$ \\
\hline Muito Fraca & Até $6 \%$ \\
\hline Fraca & De 6 a $12 \%$ \\
\hline Média & De 12 a $20 \%$ \\
\hline Forte & De 20 a 30\% \\
\hline Muito Forte & Acima de $30 \%$ \\
\hline
\end{tabular}

Figura 63. Quadro de Classes de Declividades. Fonte: Ross, 1990. 


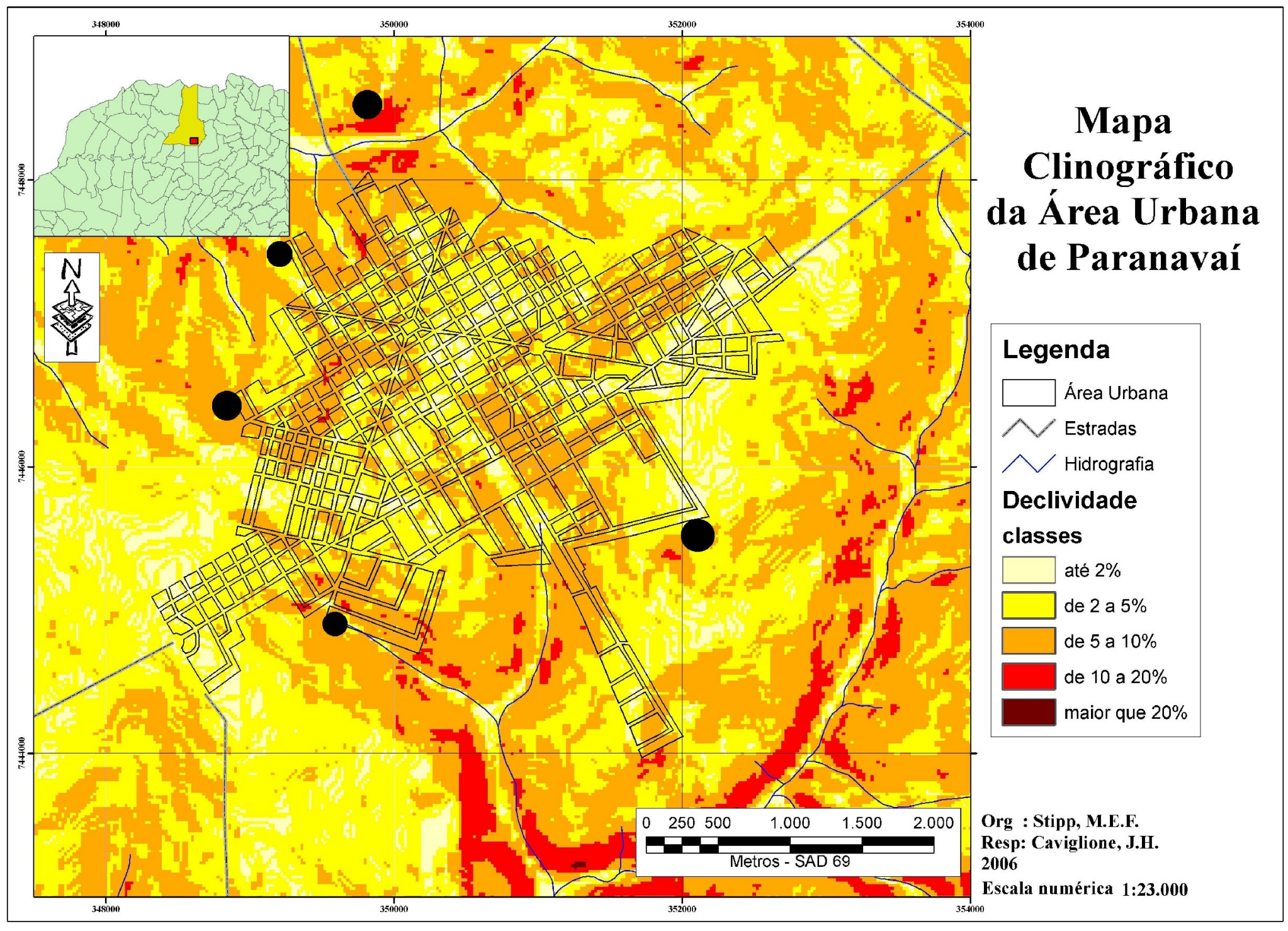

Figura 64. Mapa Clinográfico com a Localização dos Pontos de Medição. 
Para as próximas tabelas não houve a necessidade de se averiguar junto ao mapa da área, pois a sua identificação foi aferida em trabalho de campo e descrita na identificação de cada ponto de medição.

\begin{tabular}{|l|c|}
\hline \multicolumn{1}{|c|}{ CLASSES DE FRAGILIDADE } & TIPOS DE SOLOS \\
\hline 1- Muito Baixa & $\begin{array}{c}\text { Latossolo Roxo, Latossolo Vermelho- } \\
\text { Escuro e Vermelho-Amarelo textura } \\
\text { argilosa. }\end{array}$ \\
\hline 2- Baixa & $\begin{array}{c}\text { Latossolo Amarelo e Vermelho-Amarelo } \\
\text { textura média/argilosa }\end{array}$ \\
\hline 3- Média & $\begin{array}{c}\text { Latossolo Vermelho-Amarelo, Terra Roxa, } \\
\text { Terra Bruna, Podzólico Vermelho-Amarelo } \\
\text { textura média/argilosa }\end{array}$ \\
\hline 4- Forte & $\begin{array}{c}\text { Podzólico Vermelho-Amarelo textura } \\
\text { média/arenosa e Cambissolo }\end{array}$ \\
\hline 5- Muito Forte & $\begin{array}{c}\text { Podzólizados com cascalho, litólicos e } \\
\text { Areias Quartzosas. }\end{array}$ \\
\hline
\end{tabular}

Figura 65. Quadro de Classes de Fragilidade dos Solos. Fonte: Ross, 1990.

\begin{tabular}{|c|c|}
\hline GRAUS DE PROTEÇÃO & TIPOS DE COBERTURA VEGETAL \\
\hline 1- Muito Alta & $\begin{array}{l}\text { Florestas/ Matas naturais, Florestas } \\
\text { cultivadas com biodiversidade. }\end{array}$ \\
\hline 2- Alta & $\begin{array}{l}\text { Formações arbustivas naturais de estrato } \\
\text { herbáceo denso, formações arbustivas } \\
\text { densas (mata secundária, cerrado denso, } \\
\text { capoeira densa), Mata homogênea de } \\
\text { Pinus densa. Pastagens cultivadas sem } \\
\text { pisoteio de gado. Cultivo de ciclo longo } \\
\text { como o Cacau. }\end{array}$ \\
\hline 3- Média & $\begin{array}{l}\text { Cultivo de ciclo longo em curvas de } \\
\text { nível/terraceamento como café, laranja com } \\
\text { forrageiras entre ruas. Pastagens com } \\
\text { baixo pisoteio. Silvicultura de eucaliptos } \\
\text { com subbosque de nativas. }\end{array}$ \\
\hline 4- Baixa & $\begin{array}{l}\text { Culturas de ciclo longo de baixa densidade } \\
\text { (café, pimenta do reino, laranja) com solo } \\
\text { exposto entre ruas, culturas de ciclo curto } \\
\text { (arroz, trigo, feijão, soja, milho, algodão) } \\
\text { com cultivo em curvas de nível// } \\
\text { terraceamento. }\end{array}$ \\
\hline 5- Muito Baixa - Nula & $\begin{array}{l}\text { Áreas desmatadas e queimadas } \\
\text { recentemente, solo exposto por } \\
\text { arado/gradeação, solo exposto ao longo de } \\
\text { caminhos e estradas, terraplanagens, } \\
\text { culturas de ciclo curto sem praticas } \\
\text { conservacionistas. }\end{array}$ \\
\hline
\end{tabular}

Figura 66. Quadro de Graus de Proteção por Tipos de Cobertura Vegetal. Fonte: Ross, 1990. 
10.5 Resultados da Análise dos Pontos de MediçÃo

Análise dos Pontos de acordo com Ross (1990):

\section{O Ponto 01}

A classe de declividade deste ponto foi classificada como Fraca, com classe de Fragilidade Média e grau de Proteção Muito Baixo ou Nulo.

\section{O Ponto 02}

A classe de declividade deste ponto foi classificada como Fraca, com classe de Fragilidade Média e o grau de Proteção - Muito Baixo ou Nulo.

\section{O Ponto 03}

A classe de declividade deste ponto foi classificada como Muito Fraca; com classe de Fragilidade Muito Forte e o grau de Proteção - Muito Baixo ou Nulo.

\section{O Ponto 04}

A classe de declividade deste ponto foi classificada como Muito Fraca, com classe de Fragilidade Muito Baixa e o grau de Proteção - Média.

\section{O Ponto 05}

A classe de declividade deste ponto foi classificada como Fraca, com classe de Fragilidade Média e o grau de Proteção - Baixa.

De acordo com o IAPAR (1988), com a finalidade de se fornecerem subsídios para o estabelecimento dos graus de limitação com relação à suscetibilidade à erosão, deu-se importância à posição que cada solo ocupa na paisagem, aliada à declividade, formas de topos e vertentes. 
Tabela 9. Graus de Limitação dos Pontos Amostrados com relação à susceptibilidade à erosão.

\begin{tabular}{c|c|c|c}
\hline $\begin{array}{c}\text { Pontos } \\
\text { Amostrados }\end{array}$ & $\begin{array}{c}\text { Grau de } \\
\text { Declividade }\end{array}$ & Tipos de Solos & $\begin{array}{c}\text { Classes de } \\
\text { Suscetibilidade } \\
\text { à Erosão. }\end{array}$ \\
\hline 01 & 4 a $8 \%$ & $\begin{array}{c}\text { Argissolo Vermelho } \\
\text { Amarelo. }\end{array}$ & Moderada \\
\hline 02 & 4 a $8 \%$ & $\begin{array}{c}\text { Argissolo Vermelho } \\
\text { Amarelo. }\end{array}$ & Moderada \\
\hline 03 & 5 a $10 \%$ & Neossolos & Forte \\
\hline 04 & 0 a $5 \%$ & Latossolo Vermelho & Ligeira \\
\hline 05 & 4 a $8 \%$ & Argissolo Vermelho & Moderada \\
\hline
\end{tabular}

Fonte: IAPAR, 1988 - Org. Stipp, M.E.F., 2006.

Uma contribuição deste trabalho para essa região se centrou em avaliar a fragilidade e a suscetibilidade do solo, frente ao processo de erosão e da arenização, pois dentro da pesquisa realizada no Plano Diretor não foi contemplada essa problemática. 


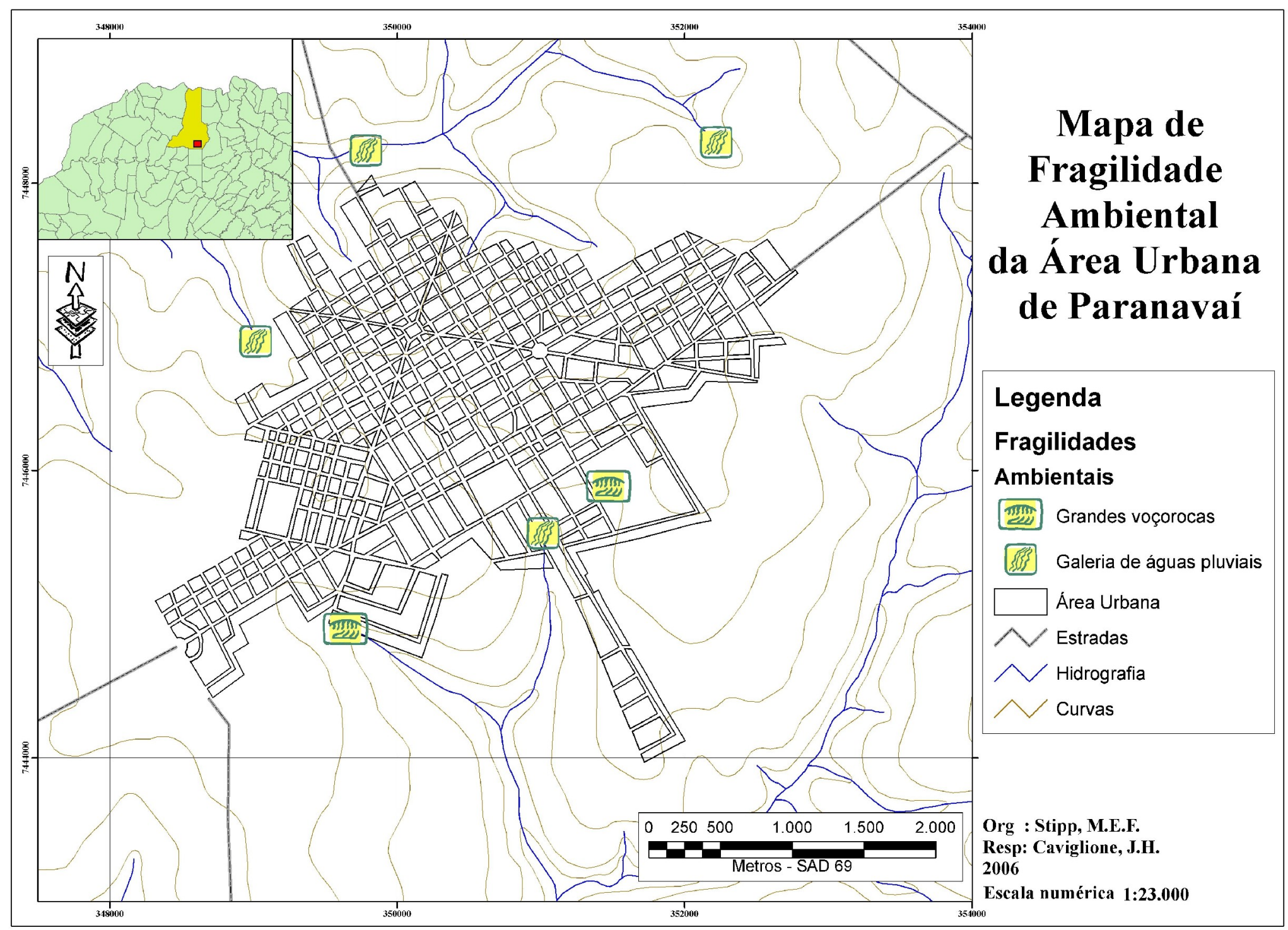

Figura 67. Mapa de Fragilidades Ambientais. 
A identificação de ambientes naturais frágeis se constitui em parte essencial ao planejamento territorial ambiental, e se faz necessário, tendo em vista que a dinâmica da natureza é freqüentemente quebrada/alterada a partir da intervenção do Homem, gerando o desequilíbrio às vezes temporários e/ou permanentes, daí sua importância neste estudo.

Tricart (1977), definiu que os ambientes em equilíbrio dinâmico são estáveis, e quando ocorre o contrário (desequilíbrio) são instáveis. Ross (1990) inseriu novos critérios para definir as Unidades Ecodinâmicas Estáveis e Instáveis, onde as Unidades Ecodinâmicas Instáveis, são aquelas cujas intervenções antrópicas modificaram intensamente os ambientes, através dos desmatamentos e práticas de atividades econômicas diversas e as Unidades Ecodinâmicas Estáveis são as que estão em equilíbrio e foram poupadas da ação do homem, em estado natural. Para que esses conceitos fossem melhor utilizados para o Planejamento Ambiental, Ross (op cit) ampliou o uso do termo,assim para as Unidades Ecodinâmicas Instáveis ou de Instabilidade Emergente em vários graus,classificou desde Instabilidade Muito Fraca a Muito Forte. As Estáveis, apesar do seu equilíbrio, apresentam Instabilidade Potencial qualitativamente previsível, pois devido a suas características naturais, podem receber a qualquer tempo inserção antrópica. Assim, as Unidades Ecodinâmicas Estáveis, apresentam-se como Unidades Ecodinâmicas de Instabilidade Potencial em diferentes graus - de Muito Fraca a Muito Forte.

De acordo com Ross (1990), pode-se concluir então, que a área em estudo pode ser classificada como Unidades Ecodinâmicas Instáveis ou de Instabilidade Emergente, com grau de Instabilidade de Fraca a Muito Fraca. 


\section{DISCUSSÃO DOS RESULTADOS}

Através da pesquisa de campo no decorrer de um ano verificou-se que o processo de degradação ambiental - arenização em áreas urbanas, está em franco desenvolvimento na área em estudo.

Como o objetivo principal deste trabalho era comprovar que o processo de arenização seria o fator determinante nos processos de transformação da paisagem urbana de Paranavaí), se fez necessário dividir os dados coletados pelas varas de medição, em estações úmidas (Outubro/2003 - Março/2004) e em estações secas (Abril/2004 - Outubro/2004), com a finalidade de se obter uma melhor visualização desse processo.

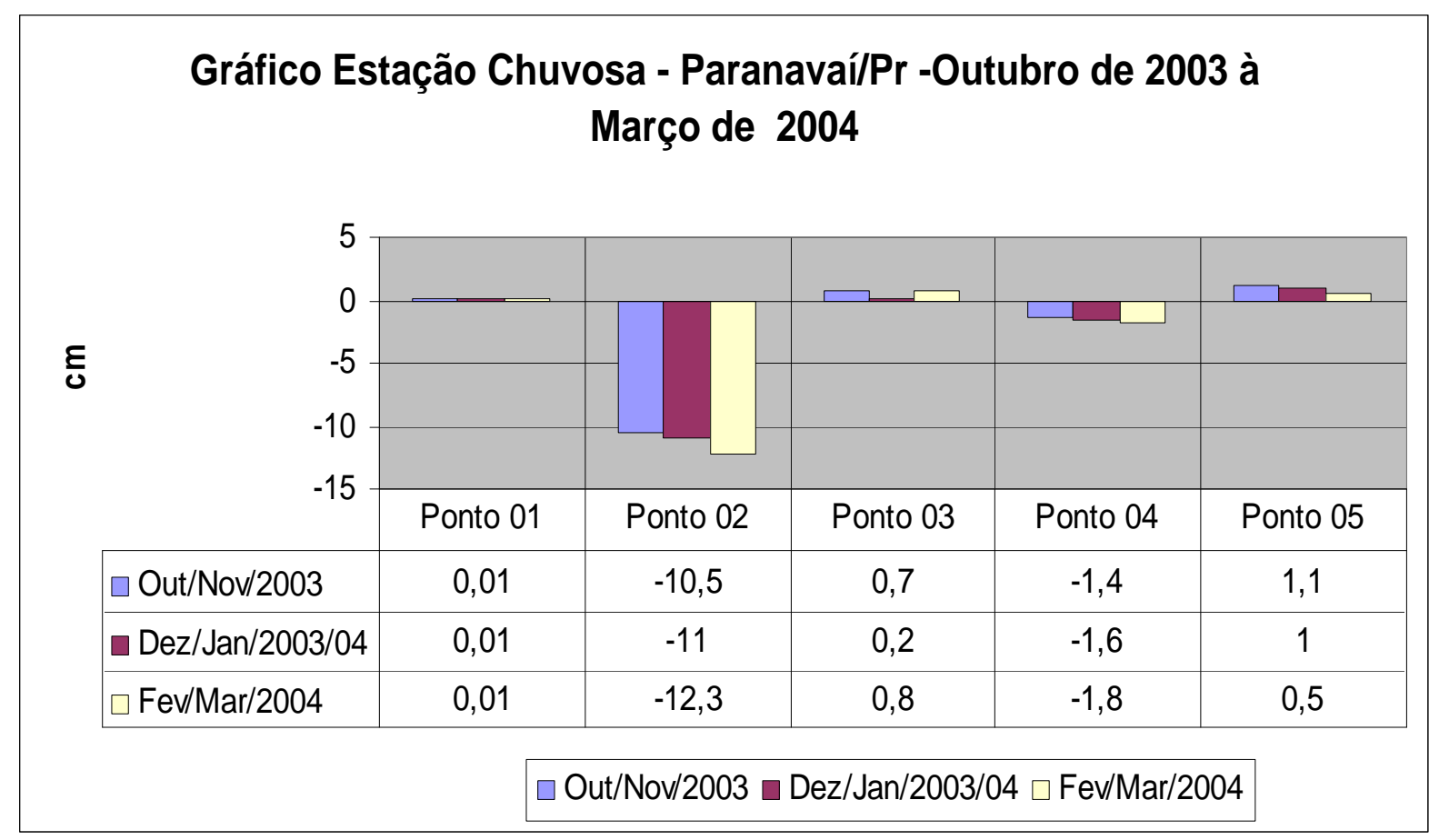

Figura 68. Gráfico da Estação Chuvosa Paranavaí/Pr. Outubro/2003 à Março/2004. Fonte: IAPAR, 2006. 


\section{Análise dos dados:}

Ponto 01 - Não apresentou carreamento do solo entre os meses novembro de 2003 até maio de 2004, fato que pode ser explicado pela contenção de terras feita pela construção do muro de arrimo.

Ponto 02 - Teve o carreamento mais expressivo de todos os pontos amostrados, pois nos primeiros dois meses de pesquisa já haviam sido carreados solos representados na vara por aproximadamente $10 \mathrm{~cm}$, quando o carreamento se deu de modo contínuo.

Ponto 03 - Nos primeiros meses da pesquisa, de setembro de 2003 a janeiro de 2004, o ponto 03 apresentou soterramento de solo, da ordem de $7 \mathrm{~mm}$, sendo que nos meses seguintes houve a inversão do fluxo, ocasionando o carreamento.

Ponto 04 - Entre setembro de 2003 a março de 2004, este ponto apresentou um carreamento de cerca de $2 \mathrm{~cm}$ aproximadamente.

Ponto 05 - Nos primeiros seis meses da pesquisa (30/09/03 $31 / 03 / 04)$, este ponto apresentou um soterramento gradativo de cerca de $2 \mathrm{~cm}$. 


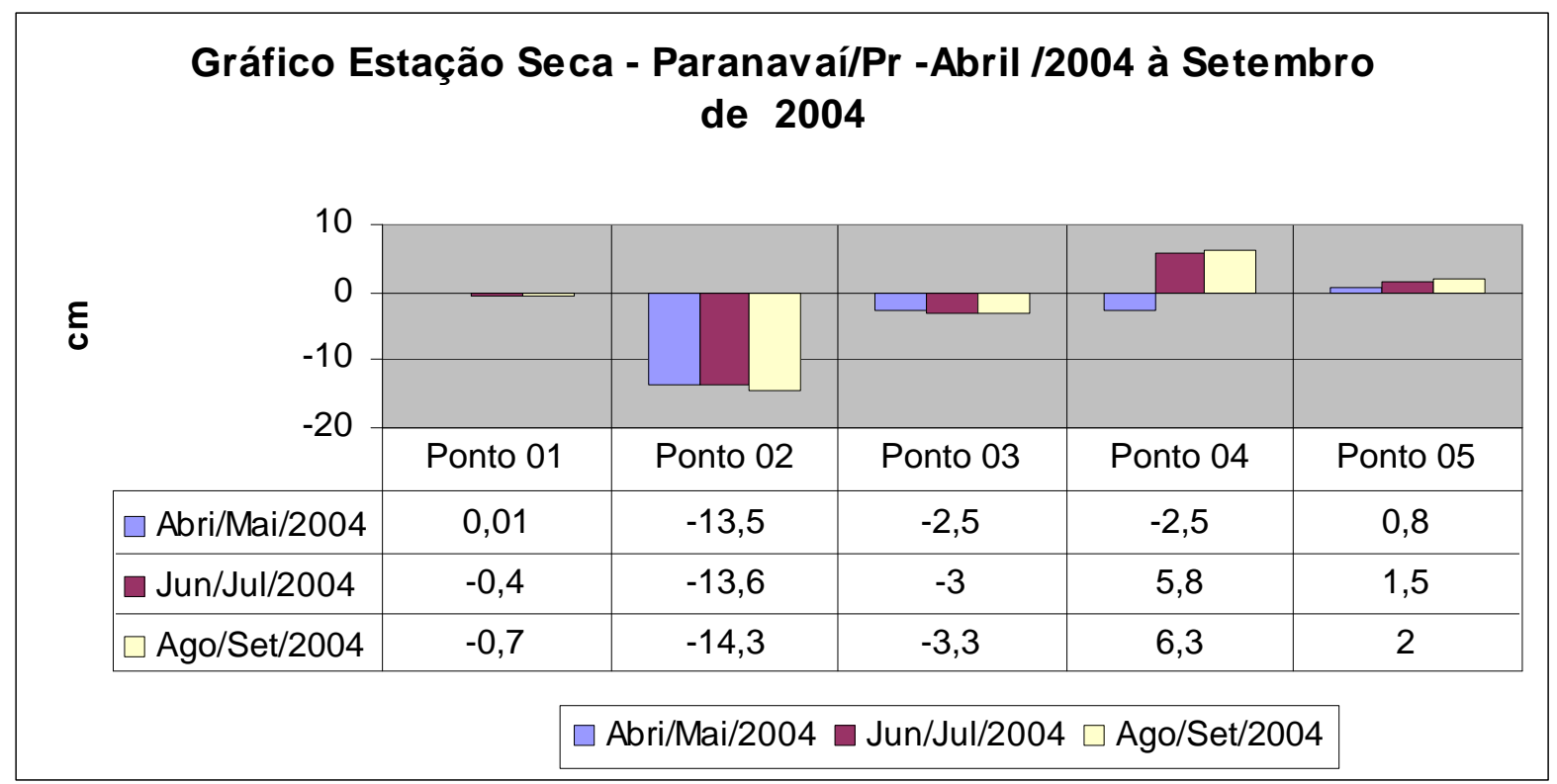

Figura 69. Gráfico da Estação Seca Paranavaí/Pr. Abril/2004 à Novembro/2004. Fonte: IAPAR, 2006.

\section{Análise dos dados:}

Ponto 01 - Este ponto apresentou nos meses de julho a novembro de 2004 um carreamento de $1 \mathrm{~cm}$.

Ponto 02 - No decorrer da pesquisa este ponto, não apresentou grandes alterações como na estação chuvosa,que teve uma pequena alteração de carreamento. Entre os meses de agosto/2004 à novembro/2004 o carreamento foi mais expressivo com cerca de $2 \mathrm{~cm}$.

Ponto 03 - O mês mais marcante no ponto 3 , foi o mês de maio de 2004, que na estação chuvosa foi soterrado em cerca de $2 \mathrm{~cm}$ acima do nível de instalação do experimento; teve uma inversão rápida e progressiva de mais de $4 \mathrm{~cm}$ de carreamento até o final da fase experimental da pesquisa (novembro de 2004). 
Ponto 04 - A partir do mês de julho de 2004 ocorreu também a inversão do movimento de terra, pois, houve um soterramento com cerca de $8 \mathrm{~cm}$ a 9cm até o mês de novembro de 2004 (final da pesquisa de campo), ou seja das observações dos pontos de amostragem.

A época mais marcante nessa área se deu entre o mês de maio e julho quando ocorreu o soterramento da vara em cerca de $8 \mathrm{~cm}$, invertendo o fluxo de terra que se acumulou na parte mais alta do declive.

Ponto 05 - No período de 31/07/04 a 30/09/04 ocorreu um carreamento de solo, com cerca de $3 \mathrm{~mm}$ e $5 \mathrm{~mm}$ respectivamente, voltando ao estágio inicial da instalação da vara de medição. Após 30/09/04 houve o soterramento de cerca de $1 \mathrm{~cm}$. O fato mais marcante ocorreu na mudança entre a estação chuvosa e seca, quando houve uma inversão do fluxo de terra na área, apesar de ser de poucos $\mathrm{mm}$, foi bastante expressivo para a análise dos dados.

O foco central nesta pesquisa é a arenização que se define como uma atividade contínua e prolongada na seqüência dos fatores de suspensão/transporte e acumulação dos solos sedimentares.

Essa operação é intensificada pela ação dos agentes erosivos pluviais e eólicos, que atuam através do deslocamento e transporte desses sedimentos.

O processo de arenização independe da cobertura vegetal existente, pois a atividade de desprendimento, suspensão do solo acontece tanto em vegetação primária gramíneas quanto em plantações agrícolas e/ou arbóreas. 0 mesmo acontece na paisagem urbana, com a deterioração das construções humanas, que também são impactadas pela ação do vento, e em locais destinados ao verde como bosques, praças e ruas sem asfaltamento.

Através da pesquisa de campo e a constatação da mobilidade dos sedimentos, pode-se afirmar que a arenização está relacionada com o clima úmido, 
como afirma Suertegaray (1987), mas a degradação não está relacionada com a abundância da água e sim com a associação dos fatores água e vento, fato esse comprovado na pesquisa experimental que demonstrou que na estação seca o carreamento do material ainda permanecia constante. 


\section{PROPOSTAS PARA RECUPERAÇÃo dAS ÁREAS COM PROCESSOS DE EROSÃO E ARENIZAÇÃO}

Para o controle e prevenção dos processos erosivos tornam-se necessárias soluções diferenciadas para cada caso. É preciso distinguir entre erosão laminar, ravinas e voçorocas, pois para recuperação e estabilização de cada processo destina-se uma forma de correção. É mais fácil corrigir um processo de erosão inicial do que estabilizar um processo de formação de voçorocas.

Suertegaray (2003) propôs algumas técnicas de fixação de areias móveis para as áreas em processo de arenização no Sudoeste do Rio Grande do Sul e/ou outras áreas arenosas do território em que se faz necessária sua estabilização.

De acordo com Mainguet (1995) apud Suertegaray (2003) pode ser utilizada uma combinação de técnicas mecânicas e biológicas de recuperação em ecossistemas onde ocorrem precipitações acima de $300 \mathrm{~mm} / \mathrm{ano}$. A técnica mecânica consiste na colocação de uma quadrícula de pequenos anteparos de 25 a $30 \mathrm{~cm}$ da superfície do solo e distante um metro entre si.

Para isso podem ser utilizados vários tipos de materiais desde a palha de milho, lâminas ou folhas de plástico ou de papelão até resíduos de colheita. Desenvolvendo-se depois uma cobertura vegetal natural ou plantada que irá estabilizar principalmente as regiões de dunas (MAINGUET, 1995) apud Suertegaray (2003).

Em Paranavaí a urbanização sem planejamento adequado e práticas agrícolas inadequadas contribuíram para a aceleração dos processos erosivos que causaram a degradação do solo. As principais causas dos processos oriundos do escoamento superficial constituem motivo de instabilidade dos solos e na área de estudo se acresce do fenômeno da arenização resultante de fatores naturais e antropogênicos, incluindo desde as variações climáticas até a ação antrópica.

Uma sugestão para a recuperação desses solos que já vem sendo utilizada em vários países é o plantio de cerca viva ou cercas arbustivas, com a 
função de proteção, controle da erosão eólica, hídrica e fixação das areias. Constituem uma das técnicas biológicas que funcionam com a finalidade de se tornar um obstáculo para a ação do vento, chuvas intensas, homem e animais.

Outra alternativa é a instalação de quebra-ventos arbóreos dispostos transversalmente às correntes principais dos ventos da cidade ou seja, fileiras de árvores de porte diferenciado organizados em escala (STIPP, 2001).

De acordo Suertegaray (2003) alguns critérios de escolha das espécies a serem plantadas nesses quebra-ventos prendem-se à resistência à seca, rápido crescimento, a disponibilidade de água e profundidade do lençol subterrâneo.

A conversão de campo de cereais em campo combinados com plantas forrageiras dispersas e conjuntos de arbustos forrageiros, principalmente de leguminosas foram propostas de Houérou (1989) apud Suertegaray (2003), pois combateriam a degradação dos solos detendo a erosão, permitindo a obtenção de alimentos, refúgio para a fauna e a caça.

Segundo Bigarella (1985), o sistema de controle da erosão urbana que pode ser adotado por uma cidade consiste basicamente em: obras de microdrenagem e macrodrenagem, constituída de emissários e dissipadores de energia, e obras de estabilização de vales receptores.

O controle da erosão e dos processos de arenização na área de estudo requer ações conjuntas de prevenção e recuperação. Prevenção para evitar que a erosão e a arenização se alastrem em outras áreas, planejando e programando a expansão urbana a partir de agora, com técnicas estabelecidas para o controle dessas atividades de degradação dos solos. Recuperação porque a cidade apresenta sérios problemas erosivos que demandam providências urgentes.

De acordo com MAZUCHOWISKI (1981), através de um Plano Diretor bem elaborado esses problemas poderão ser combatidos desde que haja uma política local para isso direcionada, estabelecendo um amplo programa de trabalho. 
O controle da erosão e da arenização requer um tratamento multisetorial integrado, envolvendo a conservação dos solos aliada a um conjunto de ações variáveis que vai desde a adequação ecológica até o zoneamento do uso do solo. 


\section{CONSIDERAÇÕES FINAIS}

No inicio da ocupação urbana os solos do NO do Paraná apresentavam razoável fertilidade natural e foram utilizados por vários anos com culturas de café e de algodão.O uso inadequado destes solos arenosos, de baixa capacidade de retenção de nutrientes levaram à troca dessas culturas por pastagens e posteriormente se deu o abandono quase que total dessas terras.

Nas zonas urbanas esse problema foi agravado pelas obras de construção civil,pela construção dos arruamentos, aterros que não foram protegidos contra às intempéries.

A cidade de Paranavaí é apenas uma fração da realidade do Norte do Paraná e para compreender o processo de voçorocamento e arenização que nela predomina foi necessário conectar outros elementos que se relacionam entre si, tais como, os fatores do meio físico e os fatores humanos.

Analisando-se os fatores do meio físico foi possível através do diagnóstico ambiental obter uma visão geral do potencial dos processos erosivos que ocorrem nessa área de estudo.

Confrontando a Carta de Fragilidade Ambiental com a Carta de Direção e Velocidade dos Ventos de Superfície e analisando-se conjuntamente os pontos de medição propostos nesta pesquisa, pôde-se perceber a importância dos mapeamentos, que forneceram subsídios para um melhor planejamento da área.

A área urbana dessa cidade revelou que os riscos de fragilidade se localizam preferencialmente na cobertura pedológica e não no substrato rochoso. Mostrou também a precariedade das galerias de captação das águas pluviais que contribuem para o intenso processo erosivo da região.

As metodologias utilizadas integradas às técnicas de geoprocessamento deram uma visibilidade do recorte espacial permitindo um maior conhecimento da realidade. 
Muitas informações obtidas após a pesquisa experimental e de laboratório foram expressas por cartas temáticas, sugerindo hipóteses que permitiriam a este pesquisador propor algumas soluções para a problemática detectada com vistas a um planejamento ambiental.

O trabalho de campo com a pesquisa experimental foi de fundamental importância por trazerem mais clareza e uma melhor visão de novos fragmentos que foram registrados em fotos.

$\mathrm{Na}$ Geografia, a integração dos fatores físicos com os fatores humanos reveste-se de relevância na análise ambiental e na obtenção das informações para um melhor entendimento da dinâmica sócio-ambiental.

A percepção ambiental no âmbito dos processos erosivos é relativamente fácil, uma vez que os sinais de desgaste são bastante visíveis, o complicado é se prever as conseqüências futuras. Por isso é preciso controlar desde o início da erosão, pois caso contrário, o ritmo da degradação do solo acelera provocando o aparecimento ravinas, barreiras em estradas, deslizamento de terras e até voçorocas.

O presente estudo pretendeu ser uma contribuição ao conhecimento dos processos interativos sociedade $X$ natureza no ambiente tropical, transformado pela ação antrópica, cujas conseqüências foram a desestabilização generalizada, manifestada pela disseminação dos processos de voçorocamento e arenização conforme procurou-se demonstrar nesta pesquisa. 


\section{REFERÊNCIAS}

AB'SABER. Espaços Ocupados pela expansão dos climas secos na América do Sul, por ocasião dos períodos glaciais quaternários. Paleoclimas, n. 6, Instituto de Geografia. Universidade de São Paulo. SP. 1977.

ALMEIDA, F. F. M. de. O planalto basáltico da bacia do Paraná. Boletim Paulista de Geografia, v. 24, p.03-34; 1956.

AUBREVILLE, A. Climats, forêts et desertification de l' Afrique Tropicale. Paris, Societé d' Éditions Géographiques, Maritimes et Coiloniales, 1949.

BIGARELLA, J. J.; MAZUCHOWSKI, J. Z. Visão integrada da problemática da erosão. In: Simpósio Nacional de Controle da Erosão, 3, Maringá 1985. Livro guia. ABGE/ADEA. 332p. (publicação especial).

BIGARELLA, J. J. Visão Integrada da Problemática da Erosão. Associação de Defesa e Educação Ambiental e Associação Brasileira de Geologia de Engenharia: Curitiba, 1985. 329p.

BUCKAMAN, H. O.; BRADY, N. C. Natureza e propriedades dos solos. 3. ed. São Paulo: Biblioteca Universitária Freitas Bastos, 1974. 594p.

CAMPOS, J. B.; SOUZA, M. C. Vegetação. In: VAZZOLER, A. E. A. de M.; AGOSTINHO, A. A.; HAHN, N. S. (ed.). A Planície de Inundação do Alto Rio Paraná: Aspectos físicos, biológicos e sócio-econômicos. Maringá: EDUEM, p. 331338, 1997.

CASSETI, V. Ambiente e apropriação do relevo. São Paulo: Ed. Contexto, 1991.

CONTI, J. B. A Geografia Física e as Relações sociedade / natureza no mundo tropical. São Paulo: Humanistas publicações - FFLCH/USP, 1997.

CONTI, J. B. A Desertificação como Forma de Degradação Ambiental no Brasil. in: RIBEIRO, W. C. (org.). Patrimônio Ambiental Brasileiro. São Paulo: Ed. da Universidade de São Paulo: Imprensa Oficial do Estado de São Paulo, 2003 (Uspiana: Brasil 500 anos).

COOKE, R. U. et al. Urban Geomorphology in Drylands. Oxford: Oxford University Press, 1982.

CUNHA, K. B. Técnicas de representações gráficas de índices morfométricos e outras variáveis aplicadas à análise do meio ambiente - estudo teórico. Tese (Doutorado em geografia) - Universidade de São Paulo/SP, 1988, 170p.

DE BIASE, M. et al. Cartas de Orientação de Vertentes: Confecção e Utilização. São Paulo: IGEO/USP, 1997. 11p. (Cartografia, nº 4).

DREGNE, H. E. Desertication of Arid Lands Economic Geography. Worcester. (USA), Clark University, n. 53, v. 4, p. 322-331, 1997. 
ELETROSUL - Centrais Elétricas do Sul do Brasil. Ilha Grande - A vegetação da área de influência do reservatório da Usina Hidrelétrica de Ilha Grande (PR/MS). Florianópolis: Eletrosul, 1986. 52p.

EMBRAPA (Empresa Brasileira de Pesquisa Agropecuária) - IAPAR (Fundação Instituto Agronômico do Paraná). Levantamento de Reconhecimento dos Solos do Estado do Paraná. Convênio SUDESUL - EMBRAPA. Governo do Estado do Paraná/IAPAR. Tomo I e II. Mapa Escala I: 600.000. Londrina (PR), 1984. 791p;

EMBRAPA (Empresa Brasileira de Pesquisa Agropecuária) - Centro Nacional de Pesquisa de Solos (Rio de Janeiro, RJ). Sistema brasileiro de classificação de solos. Brasília: Embrapa. Produção de Informação; Rio de Janeiro: Embrapa Solos, 1999. 412p.

EMBRAPA (Empresa Brasileira de Pesquisa Agropecuária) - Centro Nacional de Pesquisa de Solos (Rio de Janeiro, RJ). Sistema brasileiro de classificação de solos. Brasília: Embrapa. Produção de Informação; Rio de Janeiro: Embrapa Solos, 2002.

EMÍDIO, N. M. Aspectos Geoquímicos e Geográficos da llha dos Bandeirantes: Oportunidades e Restrições Sócio-Ambientais. 2003. 148p. Dissertação de Mestrado, em Geografia, Meio Ambiente e Desenvolvimento. Departamento de Geociências da Universidade Estadual de Londrina, Londrina PR.

FERNANDES, L. A.; COIMBRA, A. M. Revisão estratigráfica da parte oriental da Bacia Bauru (Neocretáceo). Revista Brasileira de Geociências, n. 30, v. 4, p. 723734, 2000.

FERNANDES, L. A. O Grupo Caiuá (Ks) no Paraná. In: Simpósio de Roteiros Geológicos do Paraná, 1 - SBG-UFPG - Departamento de Geociências - Ponta Grossa, p.67-78; 2002.

GASPARETTO, N. V. L.; SOUZA, M. L. de. Contexto Geológico-Geotécnico da Formação Caiuá no Terceiro Planalto Paranaense-PR. Anais do ENGEOPAR - I Encontro Geotécnico do Terceiro Planalto Paranaense - CD, p. 53-65, Maringá, 2003.

GREGORY, K. J. A natureza da Geografia Física. Rio de Janeiro: Bertrand Brasil S.A., 1992.

GUERRA, A. T. Dicionário Geológico Geomorfológico. 6. ed. Revista e atualizada pelos geógrafos Ignes Amélia Leal Teixeira Guerra e Antônio José Teixeira Guerra. Rio de Janeiro: IBGE. 1978

GUERRA, A. J. T. Processos Erosivos nas Encostas In: GUERRA, A. J. T.; CUNHA, S. B. da. (org.). Geomorfologia: uma atualização de bases e conceitos. Rio de Janeiro: Bertrand Brasil. 1994.

GUERRA, A. J. T.; CUNHA, S. B. da (org.). Geomorfologia e Meio Ambiente. 4. ed. Rio de Janeiro: Bertrand Brasil, 2003. 
HERRMANN, M. L. P.; ROSA, R. O. Relevo. In: Geografia do Brasil - Região Sul. Rio de Janeiro: IBGE, p. 55-84, 1990. Vol. 2.

HOOKE, J. M. Geomorphology in Environmental Planning. Chichester: John Wiley \& Sons, 1988.

HUDSON, N. Soil Conservation. Ithaca, New York, Cornell University Press, 320p. 1971.

IAPAR - Instituto Agronômico do Paraná. 1988.

IBGE - Instituto Brasileiro de Geografia e Estatística. Grande Região Sul. Rio de Janeiro: IBGE, 1977.

IBGE - Instituto Brasileiro de Geografia e Estatística.. Recursos Naturais e Meio Ambiente - Uma Visão do Brasil. Rio de Janeiro: IBGE, 1992.

IBGE - Instituto Brasileiro de Geografia e Estatística. Manual técnico da vegetação brasileira. Rio de Janeiro. 92p. (Série Manuais Técnicos em Geociências, n. 1), 1992.

JUSTUS, J. de O. - 1990 - Hidrografia. In: Geografia do Brasil - Região Sul. v.2. Rio de Janeiro, IBGE: 189 - 218;

LEINZ, V. 1949 - Geologia dos derrames basálticos do sul do Brasil. F.F.C.L. USP, São Paulo. Bol., 103, Geologia (5): 61p;

LEINZ, V.; AMARAL, S. E do. Geologia Geral. 7. ed. São Paulo: Ed. Nacional, 1978.

MAACK, R. Geografia Física do Estado do Paraná. 3. ed. Curitiba: Imprensa Oficial do Estado do Paraná. Coleção Brasil Diferente, 2002. 438p.

MAINGUET, M. La désertification expression de la décadance? In: L’Homme et la sécheresse. Paris: Édition Masson, 1995. p. 285-296.

MARICATO, E. Contribuição para um plano de ação brasileiro. In: BONDUKI, N. (org.). Habitat: As práticas bem sucedidas em habitação, meio ambiente e gestão urbana nas cidades brasileiras. São Paulo: Studio Nobel, 1997. 267p.

MAZUCHOWSKI, J. Z. A Experiência Brasileira no Combate à Erosão Rural "Programa de Controle da Erosão no Noroeste do Paraná". II Simpósio sobre o Controle da Erosão. São Paulo: ABGE, 1981. 256p.

MEDEIROS, C. V.; MELO. M. S. de. Processos Erosivos no espaço urbano de Ponta Grossa. in: DITZEL, C. de H. M.; SAHR, C. L. L. (org). Espaço e Cultura: Ponta Grossa e os Campos Gerais. Ponta Grossa: Editora UEPG, 2001.

MENDONÇA, F. A. O clima e o planejamento urbano de cidades de porte médio e pequeno - proposição metodológica para estudo e sua aplicação à cidade de Londrina/Pr. Londrina/UEL - USP/ Universidade de São Paulo. 1994. 320p. Tese. (Doutorado) - São Paulo. 
Moreira. M. A; Fundamentos em Sensoriamento Remoto e metodologias de Aplicação. Instituto de Pesquisas Espaciais (INPE), São José dos Campos, 2001).

NAKASHIMA, P.; NÓBREGA, M. T. de. Solos do Terceiro Planalto do Paraná Brasil. Anais do ENGEOPAR - I Encontro Geotécnico do Terceiro Planalto Paranaense - CD p. 66-85, Maringá, 2003.

NIMER, E. Clima. In: IBGE. Fundação Instituto Brasileiro de Geografia e Estatística. Geografia do Brasil: Região Sul. Rio de Janeiro: IBGE, 1990. p. 151-187.

OMM - Organisation Météorologique Mondiale. Vocabulair Météorologique. Génève: Ed. Provisoire, 1959.

OTTENS, H. F. L. The aplication of geographical information systems in urban and regional planning. In: SCHOLTEN, H. J.; STILLWELL, J. C. H. (org). Geograpkical Information Systems for Urban and Regional Planning. p. 15-22. Dordrecht: Kluwer Academic Publishers, 1990.

PERES FILHO, A. Estudo revela efeitos do uso inadequado dos solos. Jornal da UNICAMP, ed. 226, 2003. Disponível para acesso no site: < ihttp://www.unicamp.br/unicamp/unicamp hoje/ju/agosto2003/ju2226pg1 Acesso em: 16.11 .2005 .

Plano Diretor do Município de Paranavaí/ Paraná 2001.

RIBEIRO, W. C. (org). Patrimônio Ambiental Brasileiro. São Paulo: Ed. da USP: Imprensa Oficial do Estado de São Paulo, CONTI, J. B. A Desertificação como forma de Degradação Ambiental no Brasil, 2003. 167-187p.

RICCOMINI, C. et al. Características da porção basal da Formação Caiuá, noroeste do Paraná. In: Simpósio Regional de Geologia, 3, Curitiba: Atas. Curitiba: SBG, v. 2, p. 34-48, 1981.

ROSS, J. L. S. Geomorfologia: ambiente e planejamento. São Paulo: Editora Contexto, 1990.

ROSS, J. L. S. Análises e Sínteses na Abordagem Geográfica do Planejamento Ambiental. Revista do Departamento de Geografia (USP), São Paulo, v. 09, 1995.

ROSS, J. L. S. Geomorfologia: Ambiente e Planejamento. 4. ed. São Paulo: Contexto, 1997. (Repensando a Geografia).

SANTOS, M. L. dos et al. Degradação Ambiental do Noroeste do Estado do Paraná. Roteiro de Excursões do $3^{\circ}$ ENESMA-Boletim de Geografia - UEM (publicação especial) 1991. 57p.

SILVA, P. P. de L. E. et al. Dicionário Brasileiro de Ciências Ambientais. 2. ed. Rio de Janeiro: Thex ed., 2002.

STIPP, M. E. F. Análise dos Vendavais em Sobreposição à Carta de Direção e Velocidade dos Ventos de Superfície da Cidade de Londrina/Paraná. 
Dissertação de Mestrado em Geografia Física, 2001. Departamento de Geografia da FFLCH da USP. São Paulo. 101p.

STIPP, N.A.F. O Rompimento do Ecossistema na Região de Avaré - SP. Das Origens à Reformulação. Tese de Doutorado em Agronomia, 1978. ESALQ - USP. Piracicaba. SP. 81p.

SUERTEGARAY, D. M. A. (org). Terra: Feições ilustradas. Porto Alegre: Editora da UFRGS, 2003.

SUERTEGARAY, D. M. A. Desertificação: Recuperação e Desenvolvimento Sustentável. In: GUERRA, A. J. T.; CUNHA, S. B. da. Geomorfologia e Meio Ambiente. 4. ed. Rio de Janeiro: Bertrand do Brasil, 2003.

SUERTEGARAY, D. M. A. A trajetória da natureza: um estudo geomorfológico sobre os areais de quarai - RS. Tese de doutoramento em Geografia Física; FFLCH, Universidade de São Paulo. São Paulo, 1987.

TOY, T. J.; HADLEY, R. F. Geomorphology and Reclamation of Disturbed Lands. Orlando: Academic Press, 1987.

TRICART, J. Ecodinâmica. Rio de Janeiro: FIBGE/SUPREN, 1977. 97p.

TROPPMAIR, H.; FERREIRA, M. E. M. C. Cobertura vegetal, poluição aérea e deslizamentos na Serra do Mar. Geografia, Rio Claro, n. 12, v. 23, p. 117-129, abr. 1987.

WACHOWICZ, R. C. História do Paraná. Curitiba: Imprensa Oficial do Paraná, 2002. (Brasil Diferente).

WAGNER, C. S. et al. Velocidade e direção predominante dos ventos no Estado do Paraná. Londrina: IAPAR, 1989. 56p. (Boletim Técnico, n. 26).

ZACHAR, D. Soil Erosion. Ámsterdam: Elsevier Science, 1982. 


\section{BIBLIOGRAFIAS CONSULTADAS}

ANDRADE, G. O. Os climas - Brasil, a terra e o homem. Cap. VII. V.1. Cia Ed. Nacional.1964.

ASARI, A. Y.; TEIXEIRA, S. L. Do campo à periferia. Características sócioeconômicas e suas implicações no conjunto urbano de Londrina. Londrina, 1977. 247 p. Monografia (curso de especialização) - CESULON.

ASSIS, E. A. Impactos da forma urbana na mudança climática: Métodos para a previsão do comportamento térmico e melhoria de desempenho do ambiente urbano. São Paulo:FAU/USP. 2000, Tese de Doutorado.

AYOADE, J. A. Introdução à climatologia dos trópicos. Rio de Janeiro. Editora Bertrand do Brasil S.A. 2ed 1988.

BALHANA, A.; MACHADO, B. P.; WESTPHALEN, C. M. História do Paraná. Curitiba: Grafipar, 1969. 280p

BERNARDES, L. R. M. Café e Geada. Levantamento da Ocorrência e distribuição espacial do fenômeno nas regiões dos Estados de São Paulo e Paraná no período de 1870- 1975. Dissertação de Mestrado em Geografia, 1982. Universidade de São Paulo. São Paulo

BERNARDES, L. R. M.; AGUILAR, A. P. et al. Freqüência de ocorrência de verânicos no Estado do Paraná. Boletim de Geografia, 1988.

CAVALHEIRO, F. Urbanização e alterações ambientais. in: Análise Ambiental: uma visão multidisciplinar. São Paulo: UNESP/FAPESP, 1991.

CASSETI, V. (1987) Modelos estimativos de perdas geradas por efeitos pluvioerosivos, 4. Simpósio Nacional de Controle de Erosão. Marília, ABGE, p. 197-205.

CONTI. J. B. Circulação secundária e efeito orográfico na gênese das chuvas na região nordeste paulista. IGEO/USP, São Paulo, 1975, 85 p. (Série Teses e monografias, $\mathrm{n}^{-18}$ 18).

CONTI. J. B. Crescimento urbano e mudanças climáticas. Jornal O Estado de São Paulo. Suplemento Cultural, ano 3, 179, São Paulo, 09/09/1979.

CONTI. J. B. A Geografia Física e as Relações sociedade / natureza no mundo tropical. Humanistas publicações - FFLCH/USP - São Paulo. 1997

CUNHA, K. B. Técnicas de representações gráficas de índices morfométricos e outras variáveis aplicadas à análise do meio ambiente - estudo teórico. Tese (Doutorado em geografia) - Universidade de São Paulo/SP 1988, 170p. 
DE BIASI, M. A Carta Clinográfica - os métodos de representação e sua confecção. Revista do Departamento de Geografia da USP.São Paulo ํㅜ 4, 1990

DE BIASI, M. et al. Carta de Orientação de Vertentes: confecção e utilização. São Paulo, IGEO/USP, 1977. 11p. (cartografia ํㅜ 4).

DEFFUNE, G. Clima e uso da terra no Norte e Noroeste do Paraná - 1975/1986: subsídios ao planejamento regional. Dissertação (Mestrado em Geografia) Universidade de São Paulo, 1990, 214 p São Paulo.

EPA - United States Envioramental Protection Agency - Princípios de Avaliação de Impacto Ambientais - Texto de Curso Internacional de Treinamento para o Brasil. Brasil. 1993.

FRANÇA, V. de. Caracterização de uma área crítica através de análise de freqüências das inundações da Bacia Hidrográfica do Médio Iguaçu. Dissertação de Mestrado. UNESP. Presidente Prudente-SP., 1993

GEIGER, R. Manual de Microclimatologia O clima da camada de ar junto ao solo, $2^{3}$ ed. Fundação Calouste Gulbenkian, 1990, Lisboa, 639p.

GONÇALVES, N. M. S. Impactos pluviais e desorganização do espaço urbano em Salvador/Ba. Tese de Doutorado em Geografia -USP. São Paulo, 1992.

GREGORY, K. J. A natureza da Geografia Física. Rio de Janeiro: Editora Bertrand do Brasil, 1992.

LANDSBERG, H. E. The Urban Climate. International Geographie Series. Vol. 28, New York, 1981

LOMBARDO, M. A. Ilha de calor nas metrópoles: o exemplo de São Paulo. São Paulo. Hucitec, 1985.

MAACK , R. Geografia Física do Estado do Paraná. Rio de Janeiro: José Olímpio, 1981. 450p.

MAITELLI, G. Uma Abordagem Tridimensional de Clima Urbano em Área Tropical Continental: O caso de Cuiabá/MT. Tese de Doutorado em Geografia. Universidade de São Paulo. São Paulo, 1994

MARTINELLI, M. Curso de Cartografia Temática. São Paulo. Contexto. 1991.

MENDONÇA, F. A. A evolução sócio-econômica do Norte Novíssimo de Paranavaí-Pr e os impactos ambientais - desertificação? Dissertação de Mestrado em Geografia - Universidade de São Paulo, São Paulo, 1990.

MENDONÇA, F. A. Tendências climáticas do Noroeste do Estado do Paraná. In: ENCONTRO NACIONAL DE GEÓGRAFOS, 8, Presidente Prudente, 1992 Presidente Prudente, Resumos..., AGB, 1992.

MENDONÇA, F. A. O clima e o planejamento urbano de cidades de porte médio e pequeno - proposição metodológica para estudo e sua aplicação à cidade de 
Londrina/Pr. Londrina/UEL - USP/ Universidade de São Paulo. 1994. 320p Tese. (Doutorado) - São Paulo.

MOLION, L. C. B. Enos e o clima do Brasil. in: Revista Ciência Hoje, v. 10, n. 58, 1987.

MONTEIRO, C. A. F. Da necessidade de um caráter genético à classificação climática (Algumas considerações metodológicas a propósito do estudo do Brasil Meridional) Revista Geográfica, Rio de Janeiro, v. 31, n. 57, p. 29-44, 1962.

MONTEIRO, C. A. F. Clima. Grande região Sul. Rio de Janeiro: IBGE, 1968. v. 4, p. 114-116.

MONTEIRO, C. A. F. A frente polar atlântica e as chuvas de inverno na fachada sul-oriental do Brasil. (Contribuição metodológica à análise rítmica dos tipos de tempo no Brasil). São Paulo: IGEO/USP, 1969. 68p. (Séries Teses e Monografias, n. 1).

MONTEIRO, C. A. F. Análise rítmica em climatologia: problemas de atualidade climática em São Paulo e achegas para um programa de trabalho. São Paulo: IGEO/USP, 1971. 21p. (Climatologia, n.1).

MONTEIRO, C. A. F. Teoria e clima urbano. São Paulo: IGEO/USP, 1976. 181p (Séries Teses e Monografias, n 25).

MONTEIRO, C. A. F.; MENDONÇA, F. A. (org.). Clima Urbano. São Paulo: Contexto, 2003.

MONTEIRO, C. A. F.; TARIFA, J. R. Contribuição ao estudo do clima de Marabá: uma abordagem de campo subsidiária ao planejamento urbano. São Paulo: IGEO/USP. 1977. 52p. ( Climatologia, n. 7)

MONTEIRO, C. A. F. Clima e excepcionalismo - conjecturas sobre desempenho da atmosfera como fenômeno geográfico. UFSC - Florianópolis - 1991.

NAKAGAWARA, Y.; SANTANA, M. Estruturação Fundiária norte-paranaense: concentração e "capitalização" - situação - 1970- 1980. Boletim de geografia. 1984, Maringá, v. 2, p. 31-33.

NIMER, E. Climatologia de região sudeste do Brasil: introdução à climatologia dinâmica (subsídios à geografia regional do Brasil). Revista brasileira de Geografia, 1972, Rio de Janeiro, v. 34, n. 3, p. 124-453.

NIMER, E. Climatologia do Brasil. Rio de Janeiro: IBGE, 1989, 421p.

OMETTO, J. C. Bioclimatologia Vegetal. São Paulo: Ed. Agronômica Ceres Ltda., 1981.

PARANÁ - IAPAR - Instituto agronômico do Paraná. Cartas climáticas básicas do Estado do Paraná. Londrina. 1978 
RIBEIRO, A. G. Seca, Geadas e Incêndios - Uma catástrofe no Paraná e a memória dos universitários de Maringá, vinte anos depois. Boletim de Geografia, Maringá, n. 2, v. 02, p. 24-30, 1984.

RIBEIRO, A. G. Paisagem e organização espacial na região de Palmas e Guarapuava. Tese de Doutorado em Geografia 2vs - USP/São Paulo. 1989.

SANT'ANNA NETO, J. L. Mudanças climáticas no Estado de São Paulo: Contribuição metodológica ao estudo regional do clima em áreas tropicais. In: Anais VII Simpósio de Geografia Física Aplicada Vol.I UFPR Curitiba. 1997.

SANT'ANNA NETO, J. L. O clima e a agricultura. XI Encontro Nacional de Geógrafos - AGB - Nacional. Vol I - Vitória da Conquista - Bahia - 1998.

SANT'ANNA NETO, J. L. Questões metodológicas em climatologia geográfica e o problema das escalas. XI Encontro Nacional de Geógrafos - AGB Nacional. Vol I - Vitória da Conquista - Bahia - 1998.

SANT'ANNA NETO, J. L e ZAVATINI, J. A. Variabilidade e mudanças climáticas Implicações Ambientais e Socioeconômicas. Maringá: EDUEM. 2000.

SCHNEIDER, S. H. Laboratório Terra - O Jogo planetário que não podemos nos dar ao luxo de perder.Tradução de Alexandre Tort. Revisão de Rui Cerqueira. Rio de Janeiro: Ciência Atual Rocco, 1998.

SETTE, D. M. O clima urbano de Rondonópolis/MT. São Paulo: FFLCH/USP, 1996. Dissertação de Mestrado.

SIMÕES, R. M. A. Notas sobre o clima do Estado do Paraná. Revista Brasileira de Geografia, Rio de Janeiro, v. 16, n.1, p. 126-132, 1954.

SUERTEGARAY, D. M. A. A trajetória da natureza: um estudo geomorfológico sobre os areais de quarai - RS. Tese de doutoramento em Geografia Física; FFLCH, Universidade de São Paulo. São Paulo. 1987.

TARIFA, J. R. Sucessão de tipos de tempo e variação do balanço hídrico no extremo oeste paulista: ensaio metodológico aplicado ao ano agrícola de 1968/1969. Dissertação de Mestrado em Geografia. Universidade de São Paulo. São Paulo. 1973.

TARIFA, J. R. Fluxos Polares e as chuvas primavera-verão no Estado de São Paulo - Uma análise quantitativa do processo genético. Tese de doutorado em Geografia - Universidade de São Paulo, São Paulo 1975.

TARIFA, J. R. A análise topo e microclimática e o trabalho de campo: o caso de São José dos Campos. São Paulo. Instituto de Geografia da USP, 1981.

TOLENTINO, M. et al. O Azul do Planeta - Um retrato da atmosfera terrestre. São Paulo: Ed. Moderna, 1995.

TUBELIS, A.; NASCIMENTO, F. J. L. Meteorologia descritiva - fundamentos e aplicações brasileiras. São Paulo: Nobel, 1984, 374p. 
VICENTIN, C. L. Aspectos sinóticos de um evento climático extremo no Brasil de Sudeste: o caso das inundações de fevereiro de 1979. Dissertação de Mestrado USP - São Paulo, 1983

WAGNER, C. S. et al. Velocidade e direção predominante dos ventos no Estado do Paraná. IAPAR, 1989, Londrina, 56p. (Boletim Técnico, n 26.).

ZAVATINI, J. A. Variações do ritmo pluvial no Oeste de São Paulo e Norte do Paraná (eixo Araçatuba - Presidente Prudente - Londrina). Dissertação (Mestrado em Geografia) Universidade de São Paulo, 1983, 221p. São Paulo. 
This document was created with Win2PDF available at http://www.win2pdf.com.

The unregistered version of Win2PDF is for evaluation or non-commercial use only. 